\title{
Noticias sobre
}

religión: Las construcciones enunciativas de las informaciones periodísticas de actualidad religiosa en la

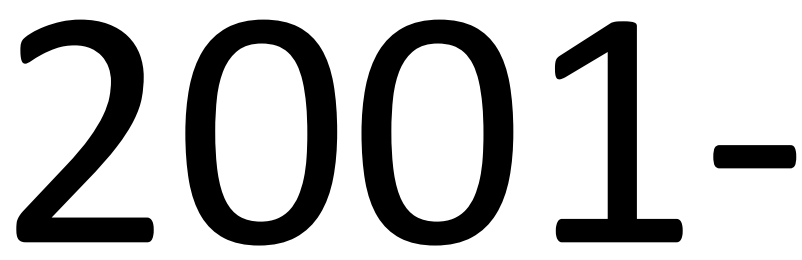
prensa escrita argentina

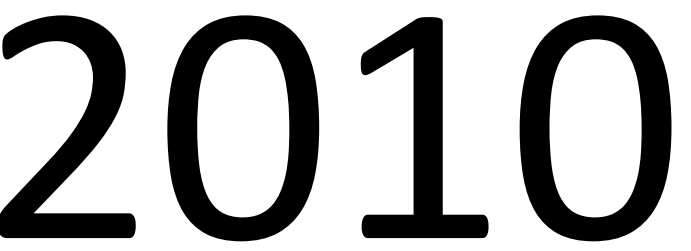

[Autor:

Facundo

Diéguez

Análisis socio-semiótico de las condiciones de producción de las noticias sobre fenómenos relativos a la religiosidad publicadas por Clarín y clarin.com, La Nación y lanacion.com, Página/12 y pagina12.com en el período 2001-2010 de la sociedad argentina
Directores:

Juan Cruz

Esquivel

Oscar

Steimberg] 


\section{DOCTORADO EN COMUNICACIÓN. UNIVERSIDAD NACIONAL DE LA PLATA. 2018}

\section{ABSTRACT}

Esta Tesis proyectó abordar un tipo de informaciones periodísticas que por su clasificación social y mediática no era evidente: las noticias sobre religión. Con regularidad aparecen en los medios enunciados -referencias, dichos, sentencias, opiniones, declaraciones- que convertidos en noticias son resultado de la propia intervención mediática, el producto de las enunciaciones de los medios relativos a los fenómenos de religiosidad.

En todo caso, a esa intervención mediática la llamamos mediatización. Tanto al resultado de interacciones sociales puntuales (p. ej. la invención de la imprenta y la Reforma luterana) como al proceso histórico (las diversas mediatizaciones de la escritura que se suman como capas geológicas en el texto, por ejemplo, de un líder religioso contemporáneo). En este aspecto, la mediatización de lo religioso no es para nada nueva -sin escritura alfabética no hay religiones monoteístas, ni religiones de salvación universal- y podríamos decir que, desde la antigüedad, lo religioso estuvo en interacción con los cambios en las tecnologías de comunicación. En el marco teórico de esta Tesis, intentamos abordar algunas de esas discusiones que involucran disciplinas diversas y que hacen a un estado del arte en permanente construcción acerca de las mediatizaciones contemporáneas.

Los cambios tecnológicos de las últimas décadas del siglo XX y primeras del XXI nos indicaron un camino en el que la adopción social de la tecnología y su adaptación fueron significativas y que, todavía, no se encuentra ni cerrado ni definido. Más aún, el componente de la aceleración mediática y su levedad o liquidez son rasgos del carácter contemporáneo de la comunicación, así como lo fueron en el pasado las posibilidades de conservar el material escrito $u$ oral de las sociedades.

En cambio hoy, la fugacidad es una propiedad presente en los objetos mediáticos y consideramos que parte de la dificultad analítica proviene de la decisión de no recortarla ni descartarla en el proceso de una investigación. En este sentido, los resguardos metodológicos y epistemológicos fueron fundamentales para un autocontrol en el análisis.

Los fenómenos contextuales como la globalización y las transformaciones en las vivencias religiosas -en discusiones teóricas de "secularizaciones" y "retornos de las religiosidades"- contemporáneas aportan su proliferación caótica a la práctica de investigar, pero también pensamos que viene dada con los objetos. Resulta inevitable cierta descontextualización para que el análisis no sea infinito; sin embargo, en el recorte y en el texto permanece parte del contexto.

En otro sentido amplio, el proyecto de la Tesis trató de abordar de manera abierta la información periodística de actualidad y sus significaciones desde el punto de vista de sus condiciones productivas y de posibilidad como un conjunto de prácticas sociales sin dejar de considerar la lógica periodística de sus productores. Pero, en especial, sin descuidar la perspectiva sobre los medios de comunicación como un sistema productivo sometido a cambios tecnológicos, en interacción con los cambios sociales.

Los resultados del análisis demostraron que: 1. los medios de comunicación tienen como uno de sus insumos recurrentes la información sobre fenómenos relativos a la religiosidad -aunque esa información pueda variar considerablemente-; 2. que no hay medio de comunicación que pueda obviar esa información sobre el mundo religioso -incluso su omisión sería llamativa-, lo que sí puede es dedicarle mayor o menor atención y decidir sus modos de tratamiento; 3 . que esa información se presenta como parte de la general, ya que en ninguno de los medios indagados hubo una sección temática específica para las noticias sobre religión; 4. que los estilos y posiciones editoriales de cada medio no fueron estancos aunque en el período 2001-2010 variaron poco en la construcción de la información sobre el mundo religioso; 5. que en los medios indagados se multiplica la figura de los periodistas especializados en la información religiosa; 6. que el predominio del credo católico continuó refractado en las construcciones periodísticas de estos medios aunque cedía lugares simbólicos a otros credos y, en algunos casos, a tendencias de espiritualidad contemporánea -los evangélicos y el budismo, algunas terapéuticas alternativas, principalmente- dentro de un panorama noticioso de relativa ampliación de la diversidad religiosa.

Estas son algunas entre otras conclusiones posibles de nuestro trabajo, ya que lo que nos interesó caracterizar fue la enunciación periodística sobre los fenómenos de religiosidad: una enunciación que consuma a los fenómenos religiosos como parte del paisaje contemporáneo de las significaciones presentes en el entramado social de lo público. Es esa enunciación periodística la que no puede ser religiosa pero tampoco dejar de prestarle visibilidad a los fenómenos sobre religión. 


\section{Presentación y agradecimientos}

Si algún mérito tiene este trabajo quisiera creer que es el de tratar de construir puentes entre la semiótica del análisis de los medios de comunicación, con los análisis de la sociología de la religión y con las ciencias sociales.

En todo caso si este mérito existe lo debo a mi director de tesis, Juan Cruz Esquivel y a los compañeros del Programa Sociedad, Cultura y Religión del Instituto CEIL, perteneciente a CONICET. Ellos fueron los que permitieron que alguien que no venía de la sociología, ni de la UBA, desarrollara su investigación en el grupo. Sus trabajos orientaron y formaron el conocimiento que intento poner en juego aquí, junto con las herramientas de análisis mediático (con el tiempo y de forma paradójica supe que los inicios del CEIL fueron en la UNLP y que, tal como sucedió conmigo, el Instituto debió mudarse para pertenecer al CONICET).

En la Introducción traté de hacer una presentación accesible a las problemáticas que encierra el abordaje de este objeto de estudio particular y relativamente novedoso en la Argentina, que podríamos llamar noticias sobre religión ${ }^{1}$. En la primera parte, en cambio, presenté las herramientas conceptuales y metodológicas con las que se trabajó en la tesis: el armado del corpus a partir de palabras clave para la búsqueda de noticias, la construcción de dimensiones de análisis, la conceptualización de la Teoría de los Géneros y Estilos de Oscar Steimberg (2013, 1993), en el marco de la Teoría de Análisis de los Discursos Sociales propuesta por Eliseo Verón (1993).

En la Presentación Conceptual del punto 3, funcionan dos marcos teóricos: por una parte, las herramientas de la semiótica de orientación peirceana tal como fue reconfigurada a partir de lo que el semiólogo italiano y discípulo de Umberto Eco, Paolo Fabbri, llamó el giro semiótico (Fabbri, 2000) y los aportes de distintas disciplinas que van desde la lógica hasta la filosofía analítica (Goodman, 1990); por otra parte, las reflexiones y discusiones que suscitaron en las ciencias sociales la irrupción de las llamadas "Nuevas Tecnologías infocomunicacionales", en particular, la propuesta de un recorrido por las materialidades significantes de la producción social de sentido en el campo de los medios de comunicación y las reconfiguraciones que produjo la irrupción de internet ${ }^{2}$.

En la Presentación Analítica traté de desplegar las primeras aproximaciones a lo que Fabbri (2000) llamó vocación empírica de la semiótica, como eslabón de pasaje al análisis empírico propiamente dicho. En el capítulo 4 hay un recorrido por las especificidades propias de nuestro objeto de estudio: las formas, géneros, lógicas

\footnotetext{
${ }^{1}$ En la Universidad de Copenhague se ha desarrollado un grupo de investigación dirigido por Stig Hjarvard que desde comienzos de la década de 2000 aborda no sólo las noticias sobre religión, sino también las problemáticas de las mediatizaciones de la religión en el conjunto de los cambios culturales recientes (Hjarvard, 2016, 2006). Es un deseo que nace con esta tesis el de construir un campo de trabajo teórico similar, alrededor de las noticias sobre religión en nuestro país.

${ }^{2}$ No quisimos seguir cierta 'ontología' propuesta en el nombre propio 'Internet' y mantuvimos el sustantivo 'internet' en esta Tesis.
} 
periodísticas e informativas propias de las noticias sobre religión en el ámbito de la prensa escrita argentina durante 2001-2010.

En el capítulo 5, que da comienzo a la Segunda Parte, a partir de las dimensiones de análisis construimos seis ejes conceptuales o categorías para focalizar relaciones específicas y organizar el análisis del corpus de noticias. Por último, las conclusiones repasan distintos tópicos ya tratados a lo largo del recorrido para finalmente dar algunas respuestas posibles acerca de las enunciaciones periodísticas construidas como noticias sobre religión en los medios indagados de la prensa escrita nacional.

Por último, un rasgo que atraviesa la tesis es que su lectura en el entorno digital permite recuperar las noticias que se citan a partir de los hipervínculos que conservamos y de algunas referencias a los diarios digitales que pueden apreciarse en la lectura del formato digital de esta tesis. El lector de la edición impresa puede de todas formas acceder a esos rasgos a partir de las indicaciones textuales tradicionales.

Esta tesis comenzó alrededor de 2008, cuando empezamos a pensar con Juan Cruz Esquivel en la posibilidad de un relevamiento y análisis de las noticias sobre religión en la prensa escrita argentina en el período 2001-2010. En aquél momento, me pareció que la cuestión de los diarios debía ser acompañada por la discusión sobre los cambios tecnológicos que atravesaban al periodismo y a los medios de comunicación en la sociedad argentina.

A su vez, había trabajado algunas cuestiones teóricas acerca de lo que llamamos mediatización en mi tesis de grado, en 2004, y creía erróneamente que las herramientas informáticas iban a ayudarme en la recolección, organización y análisis del material. Las más de 120 mil noticias recolectadas desmintieron cualquier ayuda posible por parte de las máquinas, que tampoco reconocían las distinciones necesarias para el análisis cualitativo.

A fuerza de buscar, encontré la manera metodológica para que esa recolección de noticias fuera el material al que pudiera haber accedido cualquier lector-usuario de los diarios digitales seleccionados y para que el análisis tuviera en cuenta las dimensiones propias de las condiciones de producción de las noticias, las de los aspectos de los fenómenos sobre religión y las de sus consideraciones sociológicas, así como las cuestiones mediáticas y tecnológicas propias de nuestra contemporaneidad.

La comparación de las noticias en entornos informáticos digitales con los diarios impresos permitió analizar interesantes aspectos y componentes de la mediatización de noticias sobre religión en la primera década del siglo XXI.

La posibilidad de obtener la beca de iniciación y finalización de doctorado en CONICET fue indispensable para sostener la continuidad de la investigación, que de todas maneras tuvo altibajos con mis problemas de salud y otros, como los recortes presupuestarios a partir de 2016. La voluntad de continuar pese a todo la aprendí de la vida de mi madre y por eso la dedicatoria es para ella.

Quiero agradecer a mi hija Úrsula Diéguez Peña que creció y acompañó los últimos tramos de escritura de la tesis y cuando la vio impresa, preguntó 'Papá, ¿vos escribiste todo eso?'. A mi primo hermano Julián Axat, que estuvo en los momentos difíciles y cuya casa fue un refugio para avanzar en lecturas y escrituras; a Yuri Lau quien trató de ayudarme con la cuestión tecnológica y finalmente hizo que me diera 
cuenta que lo más importante era que no había máquina que hiciera el análisis cualitativo que yo debía hacer; a Esteban Tabacznik, que siempre tuvo palabras certeras para que avance.

A Mariela Mosqueira y Damián Setton que esperaron los resultados de esta tesis y siempre fueron atentos con los avances; a Juan Eduardo Bonnin que me aconsejó en el comienzo de este camino; a Iván Pinto Veas, gran amigo trasandino; a Guido Giorgi que estuvo en la organización de los reclamos gremiales a partir de los recortes presupuestarios en CONICET. A Herminia Diéguez y Alex Carballo-Diéguez que estuvieron presentes en momentos clave de la tesis y de mi vida. A mis amigos de La Plata y del Colegio Nacional.

A Diego Paszkowski y Vicente Battista en cuyos talleres aprendí a escribir otra vez. A mi terapeuta Lidia Tarsetti cuyo acompañamiento fue fundamental para seguir y terminar esta tesis. A mis médicos, Ricardo Ronderos y Gerónimo Roselli; a Lucho, quien me ayudó con las referencias bibliográficas del capítulo sobre Asistencia Social. A Washington Uranga y Sergio Rubín quienes me orientaron con sus entrevistas sobre las problemáticas relaciones entre medios y religión. A los docentes y directivos del Jardín Maternal de la Facultad de Derecho de la UBA. A Verónica Schulman con quien recuperé la pasión por el mundo de los libros y las ideas.

Las cátedras Comunicación y Cultura I y Lenguajes Artísticos fueron ámbitos donde indagar y continuar los problemas de la investigación, en diálogo con los alumnos y los compañeros docentes. A Facundo Abalo por la defensa de mi hoja de ruta en el ingreso al Doctorado de la UNLP, a los docentes que tuve allí y a los del Centro Franco Argentino donde cursé varios seminarios. Al equipo editorial de la revista Sociedad \& Religión, en la que participo desde 2010.

Por último, le agradezco a mis maestros Raúl Barreiros, Oscar Steimberg, Daniela Koldobsky, Juan Cruz Esquivel, Fortunato Mallimaci, Aldo Ameigeiras. Por todo lo aprendido en la universidad pública. 
INDICE

Presentación y agradecimientos p. 3

1. INTRODUCCIÓN. Mediatizaciones en las noticias sobre religión p. 8

1.1 La construcción analítica de un posible objeto de estudio: la mediatización de fenómenos sobre religión y la construcción de noticias periodísticas sobre religión. p. 11

PRIMERA PARTE

2. Marco metodológico. Planteo de la investigación p. 15

$2.2 \mathrm{El}$ armado del corpus p. 16

2.3 Palabras clave: contenidos específicos, motivos y temas p. 21

2. 4 Rasgos retóricos, temáticos y enunciativos p. 22

2.4.1 Nivel de análisis de la dimensión retórica: mecanismos de configuración textual .p. 24

2.4.2 Nivel de análisis de la dimensión temática: relación de contenidos específicos-motivos-tema; referencias a acciones y situaciones pertenecientes a la cultura.... p. 26

2.4.3 Nivel de análisis de rasgos enunciativos: la puesta en escena y sus voces.

p. 27

\section{PRESENTACIÓN CONCEPTUAL.}

La ideología tecnológica y comunicacional p. 29

3.1 Significación y lenguajes p. 29

3.2 Antropología, tecnología y comunicación. p. 44

\section{PRESENTACIÓN ANALÍTICA.}

Los enfoques para el análisis empírico p. 55

4.1 Notas introductorias al análisis de las informaciones periodísticas relativas a lo religioso en clarin.com (CL.com), lanacion.com (LN.com) y pagina12.com (P12.com) p. 56

4.1.1 Observaciones descriptivas. p. 69

4.1.2 Descripción previa general $\quad$................................ p. 70

4.1.3 El tratamiento periodístico de "la Iglesia y los demás cultos" p. 75

4.1.4 Formas y formatos mediáticos p. 82

4.2 Portadas impresas y digitales p. 83

4.3 Títulos p. 84

4.4 Subtítulo o bajadas. p. 85 


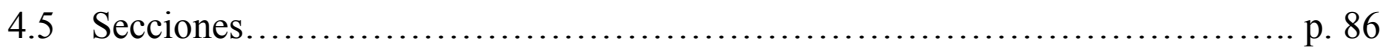

4.6 Noticias.................................................................. 87

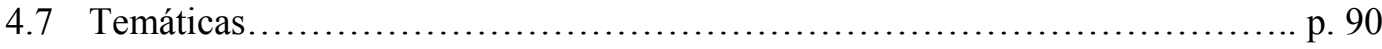

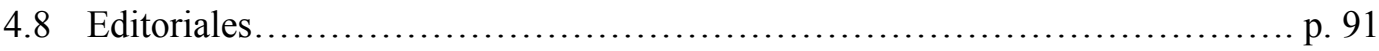

4.9 Notas y columnas de opinión.......................................... p. 93

4.10 Géneros informativos/opinativos.................................. p. 95

4.11 Narración, argumentación, descripción, comentario.................. p. 96

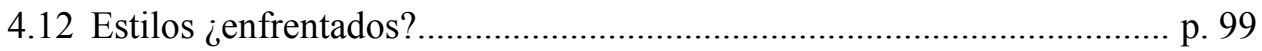

\section{SEGUNDA PARTE}

5. ANÁLISIS EMPÍRICO. El análisis sociosemiótico: las noticias como clasificaciones mediáticas en la construcción social de sentido. p. 102

5.1 Religiosidad Popular. p. 102

5.2 Educación, familia, sexualidad y reproducción sexual p. 115

5.3 Diversidad religiosa.... p. 130

5.4 Política y religión. Iglesias y Estado. p. 139

5.5 Vaticano p. 168

5.6 Asistencia social. Pobreza. p. 222

5.6.1 Las noticias sobre Caritas p. 230

6. CONCLUSIONES. p. 240

6.1 El período 2001-2010. p. 243

6.2 Caracterizaciones de las noticias sobre religión p. 247

6.3 Caracterización de los medios indagados p. 250

6.4 Los "viejos" y "nuevos" medios con internet. p. 253

6.5 Las paradojas de la 'edición impresa' en la edición digital. p. 255

7. CONCLUSIONES COMPARATIVAS SOBRE LOS MEDIOS INDAGADOS p. 258

8. BIBLIOGRAFÍA. p. 264 
Se trata más bien de mostrar que la dimensión cultural está en el centro del proceso, por el lugar que toma hoy en día el imaginario de la globalización y sus consecuencias inesperadas: mientras que durante mucho tiempo los teóricos de la modernización y de las críticas a la cultura de masas planteaban como ineluctable una secularización del mundo, cada vez más sometido a la racionalidad científica, nos percatamos de que, a la inversa, el desarrollo espectacular de los medios de comunicación hizo posibles nuevos e imprevisibles despliegues del imaginario colectivo. Los movimientos religiosos actuales atestiguan en particular esta búsqueda de nuevas trascendencias.", Marc Abélès (2012: 62).

Las ideas de Masuda, como las de Wiener y las de aquellos que de un modo $\mathrm{u}$ otro repiten postulados similares, han de situarse dentro de la misma corriente de pensamiento que desde finales del siglo XVIII considera a la comunicación como un garante de la democracia, al mismo tiempo que remedio contra la crisis económica. Idea que desde entonces ha sido renovada por diferentes generaciones técnicas. Así desde esta perspectiva, mejorar las comunicaciones es ayudar a construir la igualdad y la democracia. El carácter globalizador de la informática y la telemática marcan una nueva y decisiva etapa en la formación de esta representación mesiánica de la comunicación., Diego Levis (1999: 80).

\section{INTRODUCCIÓN. Mediatizaciones en las noticias sobre religión}

Las representaciones sociales sobre fenómenos de religión resultan, en gran medida, un producto de las escenificaciones públicas que implican las enunciaciones periodísticas sobre información de actualidad.

Al menos, desde el punto de vista de sus condiciones productivas (Verón, 1993), las noticias sobre religión conforman uno de los productos de la maquinaria mediática. Al configurar un fragmento de un proceso productivo, cuyo resultado da lo que la sociedad llama "noticias", las informaciones sobre religión forman parte de los insumos materiales para la construcción de la información periodística de actualidad.

También las noticias actúan como discurso, y como parte del discurso público (Van Dijck, 1990; Vasilachis de Gialdino, 1997, 2007). Como género discursivo, la noticia encuentra su especificidad en el sistema de una clase de textos que la sociedad organiza en un momento determinado del tiempo (Steimberg, 1993, 2013).

La sociedad diferencia los géneros periodísticos informativos como la entrevista, la crónica, el reportaje, de los opinativos como la crítica, el editorial, la nota de análisis, la columna de opinión, y lo hace tanto en sus modos de producción como en sus modos de recepción. 
En cuanto fragmentos del discurso periodístico (Verón, 1987; Charadeau, 2003, entre otros tantos autores), las noticias sobre religión implican el cruce de otros discursos previos: al menos sus retomas del discurso religioso forman parte del discurso de la información periodística de actualidad.

¿Cómo se da esta mediatización de fenómenos de religiosidad (Steimberg, 2013; Verón, 2013; Hjarvard, 2016, 2006), en particular, en nuestro país; qué acontecimientos son seleccionados por los medios de comunicación escrita para ser transformados en noticias sobre religión?

Observamos que el discurso religioso (Jitrik, 2008; Bonnin, 2012) es retomado por el discurso periodístico de la información de actualidad (Charadeau, 2003; Verón, 1987, 2013) para transformar algunos acontecimientos sociales en noticias. En particular, las que llamamos "noticias sobre religión".

Sin embargo, las noticias sobre religión no forman una sección habitual en la prensa escrita. Si bien son socialmente reconocibles tanto por otras producciones ${ }^{3}$ como $^{-}$ por los posibles ciudadanos a los que se dirigen en calidad hipotética de lectores, los medios de comunicación no suelen tener una sección temática sobre informaciones periodísticas de actualidad religiosa; no, al menos, del modo en que los medios de comunicación escrita organizan las secciones de política, economía, policiales y cultura, entre otras.

Es lo que les permite justamente a este tipo de informaciones que llamamos noticias sobre religión estar presentes en cualquier parte del diario y en combinación con otras noticias; en particular, con aquellas de las secciones sociedad y política, así como internacionales, por las informaciones relacionadas con el Vaticano.

De este modo, las noticias sobre religión no suelen constituir una sección temática propia como la deportiva, la política, la económica, la de espectáculos, ni en los diarios digitales analizados ni en sus correlatos impresos ${ }^{4}$.

\footnotetext{
${ }^{3}$ Por ejemplo, las monografías, tesis y artículos pero también por otros géneros del periodismo escrito.

4 Aunque no hay tampoco ningún impedimento técnico para que exista una sección de noticias sobre religión y, en algunos casos específicos, ha existido. Martín Vivaldi [1973: 236] cita un caso español: el del periódico $Y A$, de Madrid, con una sección denominada "Iglesia postconciliar" lo que daría cuenta también del lugar que le asignaba ese medio al Concilio Vaticano II. Sin embargo, es más habitual que se publiquen suplementos, revistas o diarios íntegramente dedicados a lo religioso como el diario católico $\mathrm{El}$
} 
Uno de nuestros objetivos específicos ha sido el de describir y analizar la capacidad que las noticias sobre religión tienen de atravesar algunas de estas secciones temáticas. A su vez, la presencia de sus contenidos temáticos es un rasgo recurrente en secciones como política, sociedad, internacionales. Las referencias a las acciones y situaciones que narran sus contenidos específicos lo son, también, por repetición esquemática de los acontecimientos sociales que se transforman en tales, a partir de sus mediatizaciones (Verón, 1996, 2013).

Podemos definir a la mediatización como fenómeno en tanto irrupción de un soporte material de signos en combinación con técnicas y prácticas sociales de acceso público (Traversa, 2001). Es decir, la aparición y existencia de un soporte o dispositivo que permite la persistencia de los signos y su autonomía (Verón, 2013).

Así, la mediatización como fenómeno produce cambios de escala espaciales (Carlón, 2006) -tales como la posibilidad de ver en directo un partido de fútbol, o un concierto, que se desarrolla a mil kilómetros de distancia-, y temporales (Bourdon, 2003) - la memoria biográfica asociada a la memoria de la transmisión de un acontecimiento en una sociedad determinada, por ejemplo: ‘¿Qué hacía yo mientras se jugaba el Mundial de fútbol de 1986?’, ‘Cómo me enteré del atentado a las Torres Gemelas en Nueva York?'.

Los cambios de escala que involucran no sólo al espacio y al tiempo sino también a la técnica, la cultura, los lenguajes, entre otros factores, afectan a las prácticas sociales y a sus combinatorias. Las mediatizaciones producen usos sociales (prácticas, creencias, representaciones) específicas, como las de la información periodística de actualidad religiosa.

Pero también podemos considerar la mediatización como proceso, aquél por el cual las sociedades dejan de ser sociedades mediáticas y pasan a ser sociedades mediatizadas:

Una sociedad mediática es una sociedad donde los medios se instalan: se considera que estos representan sus mil facetas, constituyen así una clase de espejo (más o menos deformante, poco importa) donde la sociedad industrial se refleja y por el cual ella se comunica. Lo esencial de este imaginario es que marca una frontera entre un orden que

Pueblo en las primeras décadas del siglo XX en la Argentina, o el suplemento Valores Religiosos que hace más de quince años acompaña al diario Clarín y clarín.com. 
es el de "lo real" de la sociedad (su historia, sus prácticas, sus instituciones, sus recursos, sus conflictos, su cultura) y otro orden, que es el de la representación, de la reproducción y que progresivamente han tomado a su cargo los medios (Verón, 2001b: 14).

La irrupción y aceleración de la constitución de los fenómenos mediáticos en el entramado de las sociedades contemporáneas, desde la prensa escrita de masas en el siglo XIX, hasta la radio, el cine y la televisión en el XX, marcó el pasaje de una sociedad industrial mediática al de una sociedad mediatizada.

\subsection{La construcción analítica de un posible objeto de estudio: la mediatización de fenómenos sobre religión}

El análisis empírico de nuestra investigación estuvo orientado hacia el estudio de las condiciones de producción (Verón, 1993) de las informaciones periodísticas de actualidad. En particular, indagamos en las enunciaciones que construyeron fenómenos de religiosidad en el período 2001-2010, en tres diarios digitales nacionales: clarín.com (CL.COM), lanacion.com (LN.COM), pagina12.com.ar (P12.COM) y, de manera comparativa, con sus respectivas ediciones impresas.

Focalizamos la observación, la recolección, la selección y el análisis de las noticias que abordan las dimensiones de los fenómenos religiosos en las ediciones digitales por las posibilidades relativamente novedosas que planteaba el soporte digital e hipermedial (Scolari, 2008) de internet. Este soporte tecnológico, en conjunción con el entorno informático dio acceso a un material periodístico de disponibilidad pública -las noticias y sus archivos digitales-, a partir de la popularización del uso de internet.

En el curso de la investigación analizamos cómo las ediciones digitales conservan, difunden y amplían las noticias de las ediciones impresas, al modificar la circulación física "en papel" del objeto diario 5 .

A tal punto se diferencia la edición digital de la impresa que algunos autores (Boczkowski, 2006; Scolari, 2008) no dudan en presentarlos como dos medios distintos pese a su reconocimiento social correlativo, es decir, a la identificación -por el isologo,

\footnotetext{
${ }^{5}$ Uno de los pilares de la tradicional prensa gráfica que incluye y -aunque sea obvio hay que decirlo- se diferencia de revistas, fascículos, historietas, libros y otros impresos emplazados en la distribución de mercancías tangibles.
} 
el nombre, y algunas características estilísticas- de la edición digital con la impresa, a pesar de muchas otras diferencias.

Entre los más notorios cambios destacan la materialidad significante de la presentación en pantalla del diario digital -a diferencia del soporte papel impreso-, sus procesos de digitalización, multimedialidad, participación de los lectores-usuarios, entre otras características (Piscitelli, 2005; Canclini, 2009; Dorcé, 2009; Becerra y Mastrini, 2006a; Cabrera, 2006; Castells, 1998, 2009; Scolari, 2004, 2008; Boczkowski, 2006, 2015; Igarza, 2008).

Desde nuestro enfoque, los diarios digitales son medios de comunicación cuya especificidad, respecto de los diarios impresos, es complementaria y de coexistencia. En el devenir histórico, los periódicos de papel encuentran su lugar en las mutaciones textuales (Chartier, 2008) y, en nuestro análisis, entre el conjunto de sus textos previos como condiciones de producción (Verón, 1993) ${ }^{6}$.

En cambio, es posible de manera hipotética que entre sus reconocimientos sociales el diario digital sea considerado muchas veces la "versión electrónica" del diario impreso -tal como sucedió con las iniciales transposiciones de las noticias al entorno informático-, y que luego comenzó a complejizarse con la difusión de internet.

Más allá de la discusión sobre los "contenidos" del diario digital respecto del diario impreso, es decir, cuánto conserva la edición digital de noticias de la edición impresa de noticias, una de sus características principales y específicas es que la edición online no requiere la distribución física en el espacio público de la ciudad, al modo de los productos impresos:

La tecnología del periódico impreso, que alguna vez fue nueva y que evolucionó hasta convertirse en un medio masivo establecido, hace poco empezó a apropiarse de la primera alternativa de publicación no impresa de adopción generalizada en casi 300 años, y del primer medio importante desde el surgimiento de la televisión. (Boczkowski, 2006: 2122).

\footnotetext{
${ }^{6}$ En los momentos en que el diario de papel no puede ser distribuido, en la edición digital se permite el acceso a la versión electrónica en el programa informático PDF que es una visualización del diseño en pantalla del diario impreso y sería la transposición mínima (Genette, 1989) o literal de la edición impresa.
} 
Esta sola diferencia marca el salto espacio-temporal o cambio de escala ${ }^{7}$ (Verón, 2001) entre los signos que: como cualidades pasan de las letras de molde y del diseño gráfico, a los bytes y al diseño multimedia; de los signos existenciales que indican las huellas de la tinta y el papel, a la existencia en pantallas; de los signos convencionales e inamovibles de la lengua escrita en tiempo pasado a partir del cierre de la edición en papel, a las sintaxis breves en tiempo presente, con las posibilidades de las escrituras digitales de borrar y corregir (Chartier, 2008).

Este es un salto entre mundos posibles (Goodman, 1990, 1995): de la prensa gráfica a la prensa digital, de los mundos de los medios "viejos" a los mundos de los "nuevos" medios (Igarza, 2008; Scolari, 2008) que produce rupturas de escala en la semiosis (Peirce, 1955 [1905]).

En la mediatización operan cambios de escala tecnológicos. En este sentido, los dispositivos mediáticos actúan en nuestras sociedades de un modo similar al del telescopio en la época de Galileo: el telescopio permitió ver más allá, a la distancia, pero también posibilitó observar otros fenómenos relativamente novedosos que alteraron a la sociedad que carecía de ese instrumento.

El dispositivo de ruptura de escala (Verón, 2001, 2013) que constituye el entorno informático de internet posibilita la difusión electrónica de informaciones online (Wolton, 2000) y es la primera alternativa a la difusión de informaciones escritas desde la invención de la imprenta (Boczkowski, 2006; Ivins, 1975):

\begin{abstract}
En este contexto socioeconómico, no es ninguna sorpresa que a principios de los ochenta los diarios estadounidenses comenzaran a experimentar con las computadoras personales, la televisión, los facsímiles e incluso con los teléfonos convencionales como medios alternativos para brindar información al público masivo. Pero ninguna de estas iniciativas trascendió el campo de lo experimental por más de diez años. Hacia 1995, con la popularización de la World Wide Web, los habitantes de los Estados Unidos comenzaron a tener noticias online, lo cual suministró un contexto propicio para los primeros periódicos no impresos de adopción generalizada. Esta congruencia de presión por explotar el negocio de las noticias impresas y presión por innovar en el campo no impreso hace que los diarios online sean un caso crucial para estudiar la forma en que los medios establecidos adoptan las tecnologías nuevas (Boczkowski, 2006: 20-21).
\end{abstract}

\footnotetext{
${ }^{7}$ Volveremos varias veces sobre este concepto de cambio de escala, junto con el de la irrupción de fenómenos mediáticos en el proceso histórico y la generación de rupturas de escala entre mundos posibles, para explicar la noción de mediatización.
} 
Los diarios digitales se diferencian así de los demás medios y forman parte de la historia de la invención, adaptación y adopción social (Sorlin, 2004) de las noticias al entorno informático, en conjunción con su difusión en internet (Boczkowski, 2006). 


\section{PRIMERA PARTE}

\subsection{Marco metodológico. Planteo de la investigación}

Los primeros pasos del análisis empírico trazaron el modo de recolección de las noticias a partir de los archivos -de acceso público- de las ediciones digitales de los medios, seleccionados por el criterio de su importancia social como diarios de referencia dominante ${ }^{8}$ en el espacio público argentino ${ }^{9}$.

El archivo de los diarios digitales garantizaba que el material al que accediéramos fuera el mismo disponible para cualquier usuario de internet que quisiera consultarlo. La cantidad de informaciones alojadas en estos archivos nos llevó a producir un listado de palabras clave para realizar la búsqueda.

A su vez, esas palabras clave se organizaron a partir de un orden de aparición cronológico descendente (desde 2010 hasta 2001) en la recolección de las noticias y, luego, en un listado temático de noticias. De ese modo, construimos los ejes temáticos recurrentes que fueron organizados en dimensiones de análisis ${ }^{10}$.

En base a la observación de los materiales recolectados, se procedió a seleccionar las noticias para la formación de un corpus que cumpliera con el criterio de relevancia definido en las dimensiones de análisis. Cada búsqueda por palabra clave constó de tres archivos, uno por cada medio seleccionado, lo cual produjo un corpus analítico de noventa y tres archivos.

\footnotetext{
${ }^{8}$ El criterio de pertinencia se justificó no sólo por la circulación nacional de las ediciones impresas y por la existencia de los sitios web de las ediciones digitales, sino también por los factores políticos, sociales y culturales de los diarios de referencia dominante (Albornoz, 2006: 17-29) representativos de los sectores sociales en el espacio público argentino. Los llamamos diarios de referencia dominante dado que con las ediciones digitales otra de sus reconfiguraciones es la de su "alcance": nacional, regional, local, al hacer difusas esas fronteras espaciales que estaban asociadas a la distribución física de los impresos en el país. Además, esos diarios cuentan con la figura de periodistas especializados en el tema religioso (entrevistamos a algunos de ellos), que firman sus notas y que realizan un seguimiento sistemático de las relaciones entre religión y política -en sentido amplio.

9 “... lo que la investigación empírica puede aportarnos es una visión del espacio público como un proceso de permanente convergencia y divergencia entre políticos, periodistas y ciudadanos que se fusionan y dividen entre sí en torno a temas de interés colectivo.", (Muraro, 2000: 96). Si bien consideraremos la existencia de múltiples espacios públicos, entre los cuales están los espacios públicos mediáticos en los que se construyen e interaccionan una diversidad de representaciones sociales en torno a lo religioso, nos parece interesante la conceptualización que hizo Heriberto Muraro.

${ }^{10}$ A partir de los ejes temáticos, se construyó una clasificación cualitativa en las siguientes once dimensiones de análisis: Educación sexual- Planificación familiar- Aborto- Estado/Iglesias- VaticanoAsistencia social- Religiosidades populares- Cuestiones doctrinarias- Matrimonio igualitario- Educación religiosa- Diversidad religiosa, que se vinculan con la bibliografía sobre el estudio de las relaciones entre sociedad y religión en la Argentina contemporánea.
} 
Las observaciones preliminares permitieron la sistematización en la selección de las noticias, su organización en una cronología de enunciados periodísticos sobre la temática religiosa, la evaluación del incremento de noticias sobre religión debido a una mayor atención y visibilidad de la religión en el espacio público (Casanova, 1994) por el aumento progresivo en la producción informativa que, desde 1995, implica la coexistencia de las ediciones digitales e impresas, cuyas diferencias técnicas y significantes fueron contrastadas en la construcción de las noticias de los diarios seleccionados.

\subsection{El armado del corpus}

El diseño metodológico de esta investigación se basó en la recolección de noticias que abordaron aspectos vinculados a lo religioso en el sentido amplio. Las noticias sobre religión suelen implicar otras temáticas entre sus contenidos específicos. Como habitualmente sucede en las informaciones que presentan relaciones entre religión y política, en las noticias de carácter internacional con respecto al Vaticano, o en noticias vinculadas a la asistencia social y los distintos credos, entre muchas otras temáticas posibles.

De las informaciones periodísticas de actualidad seleccionamos las noticias sobre aspectos religiosos a partir del uso de palabras clave en los buscadores de los archivos de los propios diarios digitales.

Elaboramos un listado de 30 palabras clave que arrojaron las siguientes cantidades de resultados de búsqueda en noticias de clarín.com, lanacion.com y pagina12.com:

1. Aborto- CL.com: 3238, LN.com: 3635, P12.com: $3485=10358$

2. Aguer- CL.com: 1280, LN.com: 421, P12.com: $192=1893$

3. Bergoglio- CL.com: 1204, LN.com: 2406, P12.com: $1113=4723$

4. Biblia- CL.com: 1573, LN.com: 2652, P12.com: $1237=5462$

5. Budismo- CL.com: 214, LN.com: 575, P12.com: $193=982$

6. Cardenales- CL.com: 3360, LN.com: 1151, P12.com: 239=4750

7. Caritas- CL.com: 1813, LN.com: 2803, P12.com: 392=5008

8. Casaretto- CL.com: 434, LN.com: 886, P12.com: 294=1614

9. CEA- CL.com: 492, LN.com: 1198, P12.com: 443=2133

10. CELAM- CL.com: 75, LN.com: 174, P12.com: $43=292$ 
11. Educación sexual- CL.com: 1189, LN.com: 1548, P12.com: $5000=7737$

12. Evangélicos- CL.com: 1570, LN.com: 447, P12.com: 218=2235

13. Iglesia Católica- CL.com: 4237, LN.com: 5810, P12.com: 3095= 13142

14. Igualdad religiosa- CL.com: 233, LN.com: 356, P12.com: $151=740$

15. Imán- CL.com: 82, LN.com: 111, P12.com: $1307=1500$

16. Judíos- CL.com: 8741, LN.com: 4232, P12.com: 2840=15813

17. Ley de Cultos- CL.com: 514, LN.com: 396, P12.com: 386= 1296

18. Libertad de cultos- CL.com: 535, LN.com: 679, P12.com: 103=1317

19. Libertad religiosa- CL.com: 1477 , LN.com: 1325 , P12.com: $605=3407$

20. Obispado castrense- CL.com: 316, LN.com: 130, P12.com: $142=588$

21. Obispo- CL.com: 5052, LN.com: 7183, P12.com: 2838=15073

22. Obispos latinoamericanos- CL.com: 191, LN.com: 143, P12.com: $62=$ 396

23. Pai- CL.com: 126, LN.com: 495, P12.com: 214 (con pai umbanda) $=835$

24. Pastor Evangélico- CL.com: 399, LN.com: 391, P12.com: 113=903

25. Rabino- CL.com: 1211, LN.com: 1426, P12.com: $644=3281$

26. Secretaría de Culto- CL.com: 624, LN.com: 192, P12.com: 100=916

27. Sectas- CL.com: 705, LN.com: 396, P12.com: $176=1277$

28. Te Deum- CL.com: 20, LN.com: 255, P12.com: $23=298$

29. Umbandas- CL.com: 141, LN.com: 39, P12.com: 9= 189

30. Vaticano- CL.com: 3827, LN.com: 6732, P12.com: 2041= 12600

TOTAL $=120.758$ noticias

Estas palabras clave fueron elaboradas a partir de once dimensiones de análisis sociológico sobre el fenómeno religioso:

1. Educación sexual,

2. Planificación familiar,

3. Aborto,

4. Estado-Iglesias,

5. Vaticano,

6. Asistencia social,

7. Religiosidades populares,

8. Cuestiones doctrinarias,

9. Matrimonio igualitario,

10. Educación religiosa,

11. Diversidad religiosa.

Focalizamos el análisis sociosemiótico en las noticias sobre religión de tres diarios digitales argentinos: lanacion.com, clarín.com y pagina12.com, durante el período 
2001-2010. Estos diarios tienen la particularidad de articular la edición impresa con la edición digital para ser reconocidas socialmente como correlativas. A su vez, cada uno de estos medios identifica sectores socioculturales de referencia (Albornoz, 2006).

En tal sentido, el corpus constituye un conjunto representativo de las informaciones sobre fenómenos de religiosidad. Depuramos la base empírica de acuerdo al criterio de pertinencia (Fabbri, 2000: 45; Vasilachis de Gialdino, 2006) de las noticias respecto a: las palabras clave, a las dimensiones de análisis, a la temática sobre cuestiones religiosas, a la proximidad local, regional y mundial, en el período señalado y sobre el entramado del universo de las informaciones periodísticas de actualidad en la Argentina.

En líneas generales, no se tuvieron en cuenta para el análisis ni los suplementos ni las revistas, ni las publicidades ni los espacios patrocinados que acompañan a las ediciones impresas y digitales de los diarios seleccionados ${ }^{11}$.

La selección que implicó el corpus se realizó a partir de la revisión y observación de cada noticia, en especial, como dijimos de su pertinencia (Fabbri, 2000: 45) respecto a las palabras clave y al conjunto de las 11 dimensiones de análisis propuestas. El carácter inductivo de este procedimiento también conllevó un fuerte componente interpretativo (Vasilachis de Gialdino, 2006) en la observación del material empírico y en la selección de las noticias para el análisis del corpus.

Desde el punto de vista cuantitativo, el relevamiento sobre las 30 palabras clave tuvo 120.758 resultados-noticias. A partir de la modalidad de recolección en los archivos de los diarios digitales conservamos de cada nota su hipervínculo en el título, el subtítulo -que indica detalles de la noticia- y su volanta, que suele dar cuenta de la sección y/o temática.

Junto con el título, el subtítulo y la volanta, el hipervínculo permitió recuperar la visualización de la noticia en su emplazamiento de archivo en internet y revisar la pertinencia general de cada noticia respecto a los contenidos específicos y modalidades de las informaciones periodísticas sobre religión, ingresar en el diario digital para

\footnotetext{
${ }^{11}$ Excepto el suplemento Valores Religiosos de Clarín y CL.com al cual se hizo referencia explícita como suplemento, si bien no tomamos noticias del suplemento para nuestro análisis sí hicimos observaciones sobre su funcionamiento.
} 
observarlas, confirmar esa pertinencia específica y poder observar la configuración particular de cada información para el análisis cualitativo.

El criterio de pertinencia elaborado en el Plan de Trabajo ${ }^{12}$ a partir de los objetivos generales y específicos, las hipótesis de trabajo y las dimensiones analíticas puestas en juego para la recolección de las noticias, materializó el corpus y operó como seleccionador en la cantidad de informaciones.

El análisis focalizó las noticias significativas brindadas por ese corpus, lo que permitió establecer períodos y momentos álgidos -además de una breve cronología- en las discusiones públicas de noticias sobre religión y en sus escenificaciones realizadas por los medios.

Es de destacar que en cuanto a las configuraciones formales, así como a las posibilidades y restricciones técnicas de los dispositivos (Traversa, 2001; Meunier, 1999) las noticias de los diarios digitales conservan una cierta similaridad correlativa que permite la identificación visual del diario digital con las regularidades del diseño gráfico de la edición del diario en papel.

Las regularidades de la puesta en página, de la ordenación y jerarquización, de su localización en las secciones y en los sitios web asociados a la portada digital (Boczkowski, 2006; Scolari, 2008, 2004) es la que posibilita la identificación de la edición impresa con la edición digital: los cambios y continuidades en los contenidos específicos de las informaciones periodísticas y su devenir en el tiempo presente de los medios, las posibilidades técnicas de la actualización de las noticias en los diarios digitales, los elementos multimedia, la llamada interactividad de los usuarios-lectores, la participación en las comunidades de lectores de los diarios digitales (Albornoz, 2006; Chartier, 2008, 1992: 23-40), entre otras.

Al respecto, cabe aclarar que al haber accedido a las noticias desde los archivos de los diarios digitales para el período 2001-2010, esta decisión implicó posibles

\footnotetext{
${ }^{12}$ Dirigido por el Dr. Juan Cruz Esquivel y co-dirigido por Oscar Steimberg, presentado a Conicet en 2009 para la beca de doctorado PGT I y reformulado en 2012 para la beca PGT II. Asimismo fue postulado en 2009 al Doctorado en Comunicación de la UNLP.
} 
cambios por el solo acto de conservación del material noticioso, que en algún momento estuvo en la portada y en las secciones de los diarios digitales ${ }^{13}$.

En este sentido, podemos decir que el diario de papel mantiene de manera "determinada" sus condiciones de producción (Verón, 1993, 1998) por los condicionamientos en el momento pasado de su factura en el soporte impreso, que ya no tiene posibilidades de modificar el diario una vez que se produce el cierre de la edición de papel y se imprime.

Si bien es cierto que en el diario digital esas condiciones de producción se reconfiguran casi en simultáneo a las lecturas que se realizan, también lo es que el archivo modifica el emplazamiento final de esos "contenidos" noticiosos. En cambio, las condiciones de reconocimiento tanto del diario de papel como del diario digital (Verón, 1993, 1998) permanecen abiertas a las posibles lecturas interpretativas de cada usuario-lector.

La recepción de las informaciones se modifican por múltiples circunstancias (Dorcé, 2009; Diéguez, 2011b) y tampoco son asequibles con sólo remitirse al soporte de un medio: las condiciones de recepción de las noticias del período 2001-2010 ya pasaron irremediablemente a formar parte del pasado en ambas ediciones, online e impresa, pero en este sentido el pasado alimenta, construye y está presente en el presente $^{14}$.

Por otra parte, el archivo -incluso en los diarios de papel- emplaza en una circulación distinta materiales que antes tuvieron otra circulación social, lo que Jacques Derrida llamaba "mal de archivo" (Derrida, 1994). Así es que el archivo tradicional -en nuestro caso, la hemeroteca- ya era, y todavía es, un dispositivo que cambia la construcción de sentido de las noticias, a las que guarda y conserva extraídas de su circulación social en un sistema de medios como el que está presente en las sociedades

\footnotetext{
${ }^{13}$ En lo que respecta al año 2010 y algunas temáticas específicas como los debates por la llamada ley de matrimonio igualitario pudimos seguir y observar en 'tiempo real' la cobertura noticiosa que hicieron los diarios digitales en combinación y conjunción con el sistema de medios (prensa, radio, televisión) en sus soportes tradicionales y en los relativamente novedosos que propone internet.

14 Tendremos oportunidad de discutir sobre este punto en cuanto al nombramiento de Jorge Bergoglio como sumo Pontífice del catolicismo en 2013, acontecimiento que si bien se encuentra fuera de nuestro período y cuerpo de análisis afecta retrospectivamente a las noticias previas. También hay interacciones de relativa novedad en el entorno informático de internet que hacen que haya cierta reversibilidad entre las condiciones de producción y las de recepción en las noticias de los diarios digitales.
} 
occidentales contemporáneas, al menos desde mediados del siglo $\mathrm{XX}$, y por el cual hablamos de mediatización de la información periodística de "actualidad".

\subsection{Palabras clave: contenidos específicos, motivos y temas}

Las palabras clave con las que reunimos noticias sobre religión, organizan la relación de contenidos específicos que articulan motivos y refieren a temas. Los temas son conjuntos de "motivos" -en el sentido que presentan los estudios sobre música y pintura [Segre, 1985]- formados por contenidos específicos: acciones y situaciones históricamente elaboradas, que se construyen en cada texto particular y que reenvían en su conjunto a la exterioridad de la cultura, donde los temas son reconocibles por su "representabilidad esquemática” (Segre, 1985; Steimberg, 1993).

En este sentido, nuestra investigación procedió en identificar los contenidos específicos que alimentan los motivos de las noticias sobre religión. Los grandes temas podemos organizarlos en cuatro ejes o "etiquetas": 1) autoridades religiosas, 2) cultos, 3) diversidad religiosa, 4) sexualidades. Si bien suele haber diferencias internas en relación a las palabras clave y a sus contenidos específicos, la recurrencia de contenidos y motivos en cada una de las noticias es frecuente.

En cuanto al eje 1) autoridades religiosas, hemos agrupado las noticias de las palabras clave referidas tanto a los líderes de cada credo como también a la Biblia, a las reuniones de la CELAM y la CEA, o a las noticias relacionadas al Vaticano y a las figuras de líderes religiosos: cardenales, obispos, sacerdotes, rabinos, pai, entre otros.

En relación al eje 2) llamado cultos agrupa las noticias sobre palabras clave de los principales movimientos religiosos reconocidos por los medios y practicados por los fieles en nuestro país: budismo, evangélicos, católicos, judíos, “sectas”, entre otros ${ }^{15}$.

En el eje 3) diversidad religiosa, hemos agrupado las noticias de las palabras clave referidas temáticamente con la igualdad religiosa, la libertad religiosa, la Ley de Cultos, el matrimonio igualitario, el pluralismo religioso, entre otras.

\footnotetext{
${ }^{15}$ Una palabra clave como judíos hace referencia no sólo a la religión sino también a la cultura; esta es una característica que atraviesa y diferencia a esos fenómenos religiosos. Así como la clasificación de secta, muchas veces presente en los medios, no suele ser un modo de auto-presentación de los movimientos religiosos por su acepción despectiva.
} 
En el eje 4) llamado sexualidades se organizan principalmente las noticias de las palabras clave sobre aborto, educación sexual, derechos sexuales y reproductivos, identidad de género, etcétera.

Aclaramos que estas agrupaciones atraviesan las dimensiones de análisis, las involucran como herramientas de selección y construcción del corpus, y permitieron la elaboración de categorías en el análisis empírico.

Los contenidos específicos y motivos que construyen estos cuatro grandes ejes temáticos suelen estar presentes en los textos informativos como realidad empírica aunque no agotan el problema de los niveles de análisis retórico y enunciativo, como plantearemos más adelante. Tal vez por esto, nuestra indagación se diferencia de los llamados "análisis de contenido" (Verón, 1993).

\subsection{Rasgos retóricos, temáticos y enunciativos}

El marco teórico al que remitimos para este análisis de los discursos mediáticos, de sus rasgos genéricos y estilísticos, es el propuesto en el libro Semiótica de los medios masivos (1993) de Oscar Steimberg, luego reeditado en Semióticas (2013).

En esta obra el autor plantea las proposiciones que habilitarían este tipo de análisis sociosemiótico en una Teoría de los géneros y los estilos, en particular, orientado hacia el campo de lo que se llamó estudios sobre los 'medios masivos de comunicación', con largas tradiciones en los estudios sociales (Wolff, 2004), puesto en crisis desde y por la aparición de internet (Scolari, 2008).

A partir de esta reconfiguración relativa a "nuevas" y "viejas" tecnologías empezaron a modificarse las relaciones con los medios tradicionales que se organizaban en torno al broadcasting (Scolari, 2008; Carón, 2006; Carlón y Scolari, 2009), a los géneros y a los estilos "altos" y/o "bajos" de la cultura. Aunque esto también sucedió en otras épocas, por ejemplo, en la relación que planteaba el grabado como técnica de copiado, entre la imagen pre-fotográfica y la imprenta (Ivins, 1975) y luego en la crisis del sistema de las bellas artes (Shiner, 2004) con la aparición de la fotografía y el cine.

Si bien la teoría de los géneros y estilos promovida por Steimberg ha sido pensada en el campo de los llamados medios "masivos", su propuesta no ha perdido 
vigencia: los "viejos" y los "nuevos" medios con sus relaciones de préstamos, intercambios y diferencias, han coexistido a lo largo de la historia.

Hace tiempo quedó saldada la discusión entre apocalípticos e integrados (Eco, 1997 [1968]) y entendemos que en la historia social de las tecnologías no hay reemplazos mediáticos sino desplazamientos y yuxtaposiciones, reorganizaciones. Los dispositivos tecnológicos han reconfigurado sus usos con las cambiantes prácticas sociales, ya fueran de índole pública, privada o íntima.

Incluso podemos decir que algunos de los presupuestos de la teoría semiótica que se desarrolló a partir de la recuperación de los planteos del epistemólogo Charles S. Peirce, de la figura y la obra escrita de Roland Barthes -divulgada y profundizada por Umberto Eco, en Europa (Fabbri, 2000), y por Eliseo Verón en nuestro país-, han sido popularizados.

A partir de la proliferación de los dispositivos tecnológicos de comunicación cobran nueva fuerza las materialidades de los signos, las oposiciones entre lo analógico y lo digital, las reconfiguraciones de lo "masivo" en los medios y los llamados "nuevos" medios, la apertura del sentido en el campo de la recepción y la demolición de la vieja antinomia entre pensamiento y acción, entre palabras y cosas (Fabbri, 2000; Steimberg, 2013; Carlón, 2006).

La materialidad de los signos es la que reúne en sus percepciones sociales, en sus puestas a punto tecnológicas y en los usos desempeñados lo que Peirce formuló como relaciones triádicas entre los signos: los signos-representamen, los signos-objetos y los signos-interpretantes (Peirce, 1955 [1905]) en una semiosis infinita y pluridimensional en la que el tiempo modifica incluso los objetos y las leyes de las ciencias físicas y matemáticas (Thom, 1997; Prigogine y Stengers, 1983).

Por otra parte, los objetos culturales clasificados en conjuntos genéricos y/o estilísticos desafiaron desde hace tiempo -al menos desde las primeras vanguardias artísticas del siglo XX, e incluso antes- a las clasificaciones canónicas de la literatura, del teatro y la danza.

Sus operatorias y procedimientos hacían apariciones y desplegaban novedades relativas a sus transposiciones, sus adaptaciones y cambios, en medios como la radio y la televisión (Steimberg, 1993; Steimberg y Traversa, 1997; Landi, 1992; Diéguez, 
2004) o el cine, con sus apuestas a mitad de camino en su ambivalencia entre medio de expresión artístico y medio de comunicación y divulgación para las "masas" de trabajadores de las incipientes sociedades industriales de comienzos del siglo XX, que se incorporaban a las ciudades en constante crecimiento.

En resumen, podemos afirmar que no sólo ningún medio reemplaza a los preexistentes sino que la irrupción de un fenómeno mediático como internet reconfigura el sistema de medios preexistente (Sorlin, 2004; Scolari, 2008). Algunos autores (Piscitelli, 2005) han comparado lo que produjo la aparición de internet con el momento de la invención de la imprenta, por su difusión y sus adaptaciones en los usos sociales (Sorlin, 2004).

Tampoco hay soportes o dispositivos tecnológicos en los que no se asienten obras, productos o textos que no cuenten en algún momento de su circulación social con su inscripción en clasificaciones de géneros y estilos (Steimberg, 1993: 59-65). En un sentido global, la remisión a los moldes genéricos y a las maneras de hacer estilísticas son parte del proyecto de la cultura occidental desde los tiempos en que las sociedades tuvieron relatos, ya que no hay sociedad sin relato (Barthes, 1991).

\subsubsection{Nivel de análisis de la dimensión retórica: mecanismos de configuración textual}

La propuesta de análisis textual de los rasgos retóricos (Steimberg 1993, 2013) alude a la posibilidad de comprender los mecanismos de configuración de sentido que hacen que una clase de obras o productos se componga de ciertas características formales, y no de otras, en sus configuraciones.

En nuestro caso, las diferencias en el diseño de un diario de papel respecto a un diario digital comienzan con los evidentes cambios de sus condiciones materiales de circulación: la portada impresa, que como primera página remite a las secciones en el diario de papel es, en el diario digital, una entrada en la que cada hipervínculo puede reenviar a otro sitio en el entorno informático de internet.

Las materialidades de lo impreso que se limitan a la tinta y al papel organizan las posibilidades de la fotografía de prensa, la tipografía y el diseño gráfico. En cambio, en 
el diario digital la multimedialidad -en su doble sentido: de muchos medios y múltiples lenguajes dentro de cada medio- permite la coexistencia del video digital, de la fotografía digital, de fragmentos televisivos, audios radiales, a condición de su previa conversión. De este modo, la organización de la dimensión retórica se conecta con el nivel de la materialidad de los signos en sus soportes y en sus dispositivos.

Además, la dimensión retórica comprende las relaciones que hacen a la composición del espacio, el tiempo y el relato propuestas en un objeto cultural dado: una novela necesita la sucesión temporal de la narración propia de la escritura; en cambio un producto audiovisual recurre al montaje, que puede proponer otras formas de sucesión temporal. Los mecanismos de configuración de un texto también comprenden el orden y las partes del discurso, el uso de figuras retóricas ${ }^{16}$.

En cuanto al orden y las partes del relato, el diario impreso, por ejemplo, ha privilegiado la organización de las noticias en secciones jerárquicas a partir de la portada como entrada privilegiada de lectura. En el diario digital, en cambio, predomina el criterio de actualización a lo largo de la jornada informativa como modo principal de acceso a las noticias. Las secciones se encuentran presentes como etiquetas desde el primer ingreso en la página web, lo cual hace que la portada pierda su predominio en el diario digital y modifique la propuesta de lectura de la tapa como entrada al medio ${ }^{17}$.

El uso de figuras retóricas no es ajeno a ninguna producción cultural. Las metáforas, metonimias, sinécdoques, oxímoron, quiasmos, etc., son recursos que utilizamos todos los días en el habla cotidiana y que están presentes en cualquier fragmento de lenguaje. Desde el análisis retórico se trata de establecer cuándo y de qué modo es utilizada una figura retórica en un objeto cultural dado, en relación con su pertenencia genérica o con su inscripción estilística.

Desde el punto de vista del estilo, la dimensión retórica forma parte de una manera de hacer en tanto que desde el punto de vista genérico alude a aquellos mecanismos textuales que permiten ubicarlo en un área específica de la producción

\footnotetext{
${ }^{16}$ Véase figuras retóricas en: Ducrot, Oswald y Schaeffer, Jean- Marie, Nuevo diccionario enciclopédico de las ciencias del lenguaje, Arrecife Producciones, Madrid, 1998 y Grupo Mu, Retórica general, Paidós, Barcelona, 1987.

${ }^{17}$ Esto tiene diversas consecuencias en la comparación entre diarios impresos y digitales, como cambios en la jerarquización tradicional, conexión del objeto diario digital con su entorno informático en internet, los recorridos a partir de los hipervínculos, la posibilidad de acceso online al archivo y servicios, entre otros rasgos a cuyas descripciones volveremos.
} 
cultural; por ejemplo, la placa roja del canal de noticias Crónica TV suele ser identificada con una manera sensacionalista de presentar las noticias, mientras que el formato sábana ${ }^{18}$ del diario impreso La Nación, con su tipografía azul en el nombre del diario y su organización en el diseño, suelen remitir a la prensa llamada seria o blanca $^{19}$.

\subsubsection{Nivel de análisis de la dimensión temática: relación de contenidos específicos- motivos-tema; referencias a acciones y situaciones pertenecientes a la cultura}

En esta dimensión se analizan las referencias metadiscursivas desde un objeto cultural dado, a partir de las acciones y situaciones presentes en el texto, hacia los contenidos específicos que se organizan en motivos para construir un tema exterior y presente en la cultura de la que forma parte ese texto.

Se ha dicho que los grandes temas de la cultura occidental son unos pocos: el amor, la muerte, la traición... entre otros posibles, pero la combinación de los motivos temáticos (Segre, 1985) que construyen esos grandes temas puede ser infinita: la traición amorosa que termina en muerte no se construye del mismo modo en la ópera $I$ Pagliacci que en la obra Otelo; la traición y la rivalidad familiar en Romeo y Julieta es diferente a lo planteado en las telenovelas argentinas Muñeca Brava o Perla Negra.

El análisis procede de lo particular a lo general, al identificar cuáles son los contenidos puntuales que trabaja un texto, cómo se relacionan entre sí y cómo esos contenidos específicos construyen motivos en los fragmentos (por ejemplo, la pareja amorosa que tiene que superar obstáculos en la telenovela) y en qué posibles sentidos se relacionan con los temas de la cultura (en nuestro ejemplo: el amor, la traición, la familia, etc.).

La dimensión temática es quizá una de las privilegiadas por los llamados "análisis de contenido" para los que la agenda de los medios definiría -para este tipo de análisis- los posibles sentidos de las noticias para una sociedad. Si se descuida el análisis retórico y enunciativo al privilegiar el temático, no se podrá dar cuenta de por

\footnotetext{
${ }^{18}$ En 2016 La Nación modificó por primera vez en su historia el formato sábana a uno tabloide aunque el diseño y diagramación de la edición impresa conservó su similitud en el nuevo tamaño.

${ }^{19}$ Obsérvese que en el ejemplo los estilos prensa sensacionalista-amarilla/seria-blanca se oponen en sus valoraciones sociales incluso en medios distintos como la prensa gráfica y el noticiero televisivo.
} 
qué, por ejemplo, los medios pueden tratar los mismos temas de un modo distinto (rasgos retóricos en el estilo) o por qué los medios pueden proponer distintas miradas y recortes de sus descripciones del mundo en sus propuestas de lectura (rasgos enunciativos).

En tal sentido, los temas son esquemas de representabilidad elaborados históricamente (Segre, 1985: 339-340) que un texto actualiza en la configuración particular de los contenidos específicos y de los conjuntos de motivos presentes en el texto.

En nuestro caso, los diarios digitales, así como los impresos, trabajan los diversos contenidos específicos que se articulan en motivos temáticos de la información periodística de actualidad. El alcance de los diarios digitales y su disponibilidad permite que haya, por ejemplo en el caso de clarín.com, ediciones en inglés o portugués en su propia página web, resúmenes, listas y archivos, entre otras formas de clasificación de las noticias que exceden lo temático y nos llevan hacia lo enunciativo.

\subsubsection{Nivel de análisis de rasgos enunciativos: la puesta en escena y sus voces}

La descripción analítica de rasgos enunciativos suele ser posterior al análisis de los mecanismos retóricos y de las características temáticas en el género, porque el género articula con mayor predominancia las dos primeras dimensiones sobre la enunciación (Steimberg, 1993, 2013).

En el estilo suele suceder lo contrario, la enunciación aparece en las maneras de decir lo dicho, la composición retórica suele dar cuenta de la enunciación y viceversa. Si bien el análisis enunciativo es complejo porque despliega las características simbólicas junto con las características técnicas y materiales propias de cualquier objeto cultural y de sus dispositivos, también suele ser el que nos aporta mayor riqueza.

En este nivel se analizan las diferencias en la escena enunciativa que implican características propias de cada uno de los lenguajes y de los dispositivos que se organizan en un texto o clase de textos (Traversa, 2001; Meunier, 1999).

A partir de lo retórico y lo temático se puede analizar lo enunciativo como la escena comunicacional construida en un texto entre las figuras no necesariamente personalizables de los enunciadores y los enunciatarios (Steimberg, 1993, 2013). 
Además, el análisis enunciativo considera: ¿quién/es (enunciador/es) dicen lo dicho (enunciado/s) y a quién/es (enunciatario/s) se dirigen? Lo no dicho, muchas veces, puede ser relevante para el análisis enunciativo y lo que se calla también debe ser tenido en cuenta (Kerbrat-Orechioni, 1997; Ducrot y Schaeffer, 1998; Ducrot, 2001).

Depende del análisis y de sus preguntas de investigación, la pertinencia en el abordaje del contrato enunciativo propuesto y las modalidades particulares que la enunciación adquiere en cada caso concreto, para luego definir cuáles de las recurrencias pertenecen a las clasificaciones de género y cuáles a las de estilo.

En el análisis de la prensa gráfica y digital podríamos preguntarnos cuáles son las propuestas de lectura que construye cada diario y qué lugar tienen en esas propuestas los géneros y los estilos periodísticos de cada medio; quién/es firman la nota y a quién/es se dirigen; de qué modo lo hacen; si la propuesta enunciativa forma parte del estilo del medio o, por el contrario, es una característica de ciertos géneros presentes en el diario.

A partir de los rasgos retóricos podemos decir que entre el diario digital y el diario impreso no puede haber una correspondencia exacta: la existencia de rasgos diferenciadores entre uno y otro está asegurada por la distinta materialidad de los signos, por las posibilidades y restricciones mediáticas de sus soportes y dispositivos (Diéguez, 2015). Si bien los temas pueden ser compartidos, la presentación enunciativa y el tratamiento retórico cambian con el cambio de soporte impreso al soporte digital.

A continuación veremos los presupuestos teóricos y conceptuales que guían el análisis sociosemiótico que hemos realizado, una crítica a la idea de comunicación que parte del modelo del signo propuesto por desarrollos en la semiótica peirceana y un estado del arte acerca de la relación entre las nuevas tecnologías de comunicación y sus problematizaciones realizadas por diversas disciplinas de las ciencias sociales. 


\section{PRESENTACIÓN CONCEPTUAL. La ideología tecnológica y comunicacional}

\subsection{Significación y lenguajes}

Barthes afirmó que el logro supremo del realismo del siglo XIX, tanto en la literatura como en el comentario social, fue sustituir subrepticiamente por una imagen ya textualizada del mundo la realidad concreta que icónicamente fingía representar.

Hayden White, El contenido de la forma.

\section{La idea de comunicación}

La idea según la cual el lenguaje sirve para la comunicación ha dominado la configuración de las ciencias humanas desde la época clásica y hasta mediados del siglo $\mathrm{XX}^{20}$ (Barthes, 2003; Foucault, 2002).

No es evidente, sin embargo, que el uso del lenguaje haya tenido siempre esta función: que el lenguaje sólo sirva a los efectos de traducir el pensamiento, de manera lineal y automática fue una de las instrumentalizaciones realizadas sobre el lenguaje por los modelos funcionalistas (Verón, 1993).

La utilización de la escritura en sus capacidades de registro, memoria, poetización, pensamiento científico - por señalar sólo algunas- excede largamente la idea de un lenguaje dedicado por entero a los fines de la comunicación unívoca entre los hombres. Incluso, cabría pensar el exceso de significación -la famosa polisemia- que se genera en las múltiples dimensiones de los universos simbólicos humanos (Cassirer, 1967 [1944]).

La concepción del lenguaje de textura realista -tal como se afirma en el acápiteexcluyó las posibilidades significantes de registros alejados de la lengua; registros de lenguajes de representación visual y audiovisual, por ejemplo, ya que:

\footnotetext{
${ }^{20}$ Roland Barthes desarrolló esta idea en relación con la escritura en: "Variaciones sobre la escritura", Variaciones sobre la escritura, Paidós, Buenos Aires, 2003. Foucault, Michel, Las palabras y las cosas: una arqueología de las ciencias humanas, Siglo XXI, Buenos Aires, 2002; este autor destaca las distintas concepciones rerpresentacionalistas en el seno de las ciencias humanas desde el Renacimiento, y hasta nuestros días.
} 
... en la medida en que son significantes, los objetos, las imágenes, los gestos, etcétera, remiten a algo que no puede ser dicho más que a través de ellos, con la única salvedad de que el significado semiológico puede ser asumido por los signos de la lengua." (Barthes, 1974: 35).

La idea que presuponen la mayor parte de las modernas teorías de la comunicación se constituyó en el particular desarrollo teórico que adquirió la noción en los estudios sociales durante el siglo XIX. Hacia el interior del paradigma positivista y en continuidad con la tradición cartesiana que excluyó la materialidad física del cuerpo, como parte de la res extensa, las teorías de la comunicación en su reformulación cibernética (Leavis, 1999) privilegiaron las búsquedas de explicaciones que acentuaron la reflexión autoconsciente de la mente, de los pensamientos del cogito:

\begin{abstract}
Wiener, siguiendo el tajante rechazo al cuerpo que caracteriza a la cultura judeocristiana (y a la oriental) - tan bien expresado por el pensamiento cartesiano- concibe un hombre cuya identidad física no consiste en la materia de la que está compuesto, sino en la información que contiene. Así el cuerpo se va disolviendo hasta adquirir un curioso aspecto digital en el que tiende a desaparecer definitivamente... Para Wiener el Ser es información pura... (Levis, 1999: 68).
\end{abstract}

En cambio, los estudios sobre la sociedad privilegiaron las motivaciones del actor social en la explicación de su conducta sobre la dimensión simbólica de los fenómenos culturales; al menos, así lo hicieron en el pasaje del estudio de la acción social al estudio de la voluntad intencional del sujeto (Verón, 1968, 1993) en distintas versiones de la sociología y la lingüística funcionalista, dominantes en la primera mitad del siglo $\mathrm{XX}^{21}$.

Asimismo, la configuración de la lingüística moderna produjo la oclusión de la investigación de los objetos culturales específicos que formaban parte de la producción social de sentido, porque creyó que al estudiar la lengua como objeto estable podía excluir el estudio del habla en su ilusión de fortalecer el método lingüístico:

\footnotetext{
${ }^{21}$ Según Eliseo Verón las primeras teorías de la comunicación surgen en el entre-juego del pasaje de la sociología weberiana al funcionalismo de Talcott Parsons y Robert Merton, y de la lingüística saussuriana al estructuralismo de Roman Jakobson y Claude Lévi-Strauss; véase Verón, Eliseo, "El sentido de la acción social”, Conducta, estructura y comunicación, Jorge Alvarez, Buenos Aires, 1968.
} 
La ciencia de la lengua no sólo puede prescindir de los demás elementos del lenguaje, sino que sólo es posible a condición de que esos otros elementos del lenguaje no intervengan (de Saussure, 1993: 41).

Al desterrar de su ámbito de indagación al producto material del habla, el sonido, la lingüística elaboró una concepción que suponía estudiable a la lengua y al dominio de la escritura como "transcripción del habla",22.

El funcionalismo, luego, intentaría reintroducir el dominio del habla al definir la comunicación como la intención que realiza un sujeto hablante para alcanzar un fin, aunque abordando el estudio de la frase (objeto de la lingüística) por fuera de sus manifestaciones materiales y efectivas, es decir, la situación interpersonal del habla ${ }^{23}$.

Es en este esquema de pensamiento donde se define la idea del lenguaje como un medio para la expresión de la voluntad individual. El lugar de privilegio que se le otorga al emisor en el modelo comunicacional -extraído, por otra parte, de la Teoría Matemática de la Información y en homología con las investigaciones sobre la ingeniería telefónica- concibe a la comunicación de manera individual, lineal, unidireccional, monocausalista.

La constitución del lugar de la recepción en la relación causa-efecto presentó al individuo receptor del supuesto mensaje como una "tabla rasa" en la que se inscribía la voluntad del emisor, sin posibilidades de respuesta en el caso de la comunicación no interpersonal de los llamados medios masivos ${ }^{24}$.

El edificio conceptual que se elaboró en torno a la intención del sujeto hablante, reincorporado por el primer saussurianismo al estudio de la lingüística, adquirió un amplio desarrollo teórico que recorrió todo el campo de estudios conocido como la Communication Research (De Fleur y Ball, 1982; Wolff, 2005).

\footnotetext{
${ }^{22}$ Es la paradoja en la que se encierra la concepción moderna del lenguaje, según Barthes (1974), al excluir el habla del estudio del lenguaje una vez que se hubo definido la lengua como su transcripción.

${ }^{23}$ Puede verse un recorrido de la discusión en: Verón, Eliseo, "Primera conferencia", Semiosis de lo ideológico y del poder. La mediatización, Oficina de Publicaciones del CBC de la Universidad de Buenos Aires, Buenos Aires, 1997.

${ }^{24}$ Eliseo Verón cuestiona esta caracterización, comúnmente aceptada, al decir (en tercera persona sobre sí mismo): "El había propuesto, hace años, algunos criterios para definir lo que es la comunicación mediática (tradicionalmente llamada masiva, expresión que se debe abandonar porque las audiencias de los medios no son ni nunca fueron masas).", "Destinatarios", Efectos de agenda, Gedisa, Barcelona, 1999, p. 139
} 
Las teorías que le siguieron, unas veces en simultáneo, otras en oposición, trataron de ir complejizando el universo de variables que intervenían en el dominio de la comunicación a partir de investigaciones empíricas que, sin embargo, presuponían el esquema comunicacional de base (emisor-mensaje-receptor) sin cuestionarlo.

Por más que la Escuela de Palo Alto, con las propuestas de Gregory Bateson y Erving Goffman, entre otros, y los desarrollos de la teoría cibernética de Norbert Wiener (Wiener [1958] 1988; Winkin, 1982), se esforzaran por ver diferencias entre los lugares de la emisión y la recepción, no dejaron de apelar a homologías entre los modelos de comunicación y los desarrollos teóricos que provenían de otras ciencias.

El esquema del feedback (Wiener [1958] 1988) permitió la incorporación de la capacidad de respuesta a partir del concepto de retroalimentación. También, desde la antropología y la psiquiatría norteamericana contemporánea (Watzlawick, Beavin y Jackson, 1971; Ruesch y Bateson, 1965) acentuaron las particulares modalidades de comportamiento a las que da lugar el intercambio de "mensajes", ampliando la complejidad analítica sobre la circulación del sentido social en el orden de la gestualidad, la corporalidad, la comunicación proxémica.

Se trataba, por una parte, de situaciones interpersonales, a las que se le sumaba un modelo de la comunicación proveniente de los desarrollos de la cibernética. La dimensión social del sentido se hallaba lejos de ser abordada por una propuesta de explicación propia de las ciencias humanas que contemplara las diferencias -sobre todo materiales de la concepción sígnica- en los procesos de la comunicación mediática.

En Europa, en cambio, la preanunciación de "una ciencia que estudie la vida de los signos en el seno de la vida social" ${ }^{25}$, tal como Saussure postuló a la semiología, encontraba sus herramientas hacia el interior del campo de la lingüística; campo que se iría ampliando hasta concretar la necesidad de su emancipación. Entre otras, la obra de Roland Barthes ha sido una de las propuestas del cambio de paradigma que permitió el pasaje de una semiología ligada al estudio de la lengua, a una semiótica orientada al estudio de los procesos sociales de producción de sentido (Fabbri, 2000).

El pasaje de una lógica de pensamiento científico binaria a modelos ternarios en la concepción del signo, con la recuperación de propuestas como la del epistemólogo

\footnotetext{
${ }^{25}$ Saussure, Fedinand de, Curso de lingüistica general, Planeta- De Agostini, Barcelona, 1993, p. 42.
} 
norteamericano Charles Sanders Peirce (Eco, 1994; Fabbri, 2000), posibilitó la apertura de un campo de desempeño teórico en el que comenzaron a replantearse los problemas de la comunicación social y la redefinición del campo de estudios a partir de su nombre mismo, al posicionarse desde el punto de vista del estudio de los lenguajes sociales.

De este modo, podemos decir que los presupuestos que se afirmaban en la implicación de que el lenguaje sólo sirve a la comunicación disimulaba el trabajo que realiza la producción social de sentido, en una concepción sedimentada sobre los hombros de una ciencia positivista, primero, y funcionalista después, que se constituyó en la tradición dominante de la modernidad.

\section{El hábito de representar}

Con el lenguaje, sucede que el hábito de considerarlo como instrumento que tiene la finalidad de la expresión intencional de un sujeto hablante encubre el hecho de que su materia significante también se halla constituida por la apropiación que realiza el lenguaje, de los objetos: cualquier acto de representación constituye una acción y una figuración de comportamiento que sobrepasa a su "contenido", pero lo que dificulta aún más la deconstrucción del hábito de la representación es su utilización permanente para acceder a lo que llamamos "mundo" (Nietzsche, (1951 [1873]); Cassirer, 1967; Wittgenstein, 1989, 1999; Foucault, 2002; Goodman, 1990).

En el uso del lenguaje se nos presenta la creencia de que, al nombrar objetos o al señalarlos, son éstos los que nos devuelven la imagen de correspondencia entre el acto de lenguaje y el objeto designado. La fuerte naturalización que hace corresponder "algo" con su representación se duplica en la imposibilidad de acceso a los entes originarios (Sini, 1985).

Entre los presupuestos que no nos permiten sostener la idea de comunicabilidad se encuentra el problema -radical para la filosofía del lenguaje- acerca de si el objeto designado preexiste al acto de su designación. La aparente coincidencia de las representaciones con los objetos que designan se disuelve cuando se reencuentra el proceso de metaforización ${ }^{26}$ cultural constante (Lakoff y Johnson, 1995) que las ha

\footnotetext{
${ }^{26}$ Uno de los primeros filósofos en señalar este proceso y cuestionar la posibilidad de una percepción exacta del mundo ha sido Friedrich Nietzsche en su definición de la verdad como ideal de la correspondencia en las designaciones hechas con el lenguaje que no sería más que la lucha constante de
} 
formado a lo largo del tiempo histórico y según los espacios sociales de pensamiento en que se ubica su desarrollo.

Difícil resulta, entonces, considerar que el objeto designado preexiste como una materia estable y única, predeterminada, si se tiene en cuenta el proceso de metaforización, de redescripción múltiple, que los usos del lenguaje varían de una civilización a otra y en épocas históricas distantes.

El término comunicación remite al campo social (Bourdieu, 2000) y al juego de lenguaje (Wittgenstein, 1989, 1999) de una disciplina y de un abordaje del pensamiento sobre las sociedades contemporáneas, que ha teorizado la articulación de correspondencias a partir de analogías y reenvíos metonímicos surgidos de un paradigma mecanicista: la conjunción de la Teoría Matemática de la Información y la psicología conductista (Wolff, 2005).

Lo que se reencuentra en la concepción dominante del lenguaje hasta mediados del siglo XX -desde el punto de vista crítico, que plantea una epistemología no determinista como la peirceana- es el deseo de concordancia, de correspondencia, en la atribución de un nombre a una supuesta "cosa", nunca en su totalidad, si no ya representada en alguna de sus relaciones. El hábito de la designación establece el lazo representativo que afirma la conjunción del nombre y lo nombrado (Enaudeau, 1998).

De ahí, que sostener la idea de que existe algo llamado “comunicación” equivale a reproducir el mismo hábito por el cual se afirmó antes la correspondencia entre la descripción, la referencia y su mención (Meyer, 1987).

La idea de comunicación surge entonces del juego de tensiones entre el deseo socialmente compartido de correspondencia y de la ley que instituye la repetición: el hábito de relacionar una referencia a un signo de "hecho", con su marca de inscripción sobre una superficie, sólo puede constituir el espacio representacional que forma la circulación del sentido en el uso que las sociedades realizan de los lenguajes.

El juego de lenguaje de la correspondencia (Wittgenstein, 1989) afirma la designación dentro del acto representativo y constituye la posibilidad misma de la

un ejército móvil de metáforas, metonimias antropomorfismos; véase Nietzsche, F., "Introducción teorética sobre la verdad y la mentira en su sentido extramoral", (1873), en Obras completas, Buenos Aires, Aguilar, Tomo I, 1951. 
representación. Desde el punto de vista de la semiótica de Peirce, la representación es una de las operaciones que establece el signo cuando el interpretante lo conecta con el objeto al que se refiere “... en algún aspecto o carácter (ground)"27.

La correspondencia y el lenguaje resultan una tautología en el universo clausurado de la semiosis: los signos remiten siempre a otros signos, no a un "afuera" del lenguaje que resultaría imposible. Para postular la existencia de signos hay que admitir "algo" que no lo sea al menos completamente: signos que no fueron considerados en un momento determinado del tiempo y luego pasan a un primer plano, una "novedad" en el sentido de la información periodística de actualidad que no es algo absolutamente nuevo pero donde signos anteriores comienzan a considerarse desde otro enfoque... Ese "algo" es de donde procede el cambio, el movimiento, lo infinito de la semiosis (Verón, 1993).

La relación del signo-representamen con su objeto instaura el orden de las cualidades, de la primeridad, donde se define al icono que funciona por semejanza. El signo-objeto lo conecta con una existencia de hecho, el orden de la segundidad, con la materialidad del signo y constituye la relación indicial.

Es en el correlato de la terceridad cuando se completa la cadena de inferencias abductivas ${ }^{28}$ por la que se construyó el signo en el movimiento de la semiosis. Entonces el interpretante permite establecer el hábito en el orden de la relación simbólica del signo en tanto ley reconocida por una comunidad, en un área precisa de la semiosis. Esta cadena de inferencias abductivas se realiza en un ground que constituye el fundamento del objeto inmediato (Verón, 1993) en relación con el proceso infinito de los signos.

\footnotetext{
${ }^{27}$ La definición completa del signo: "Un signo, o representamen es algo que, para alguien, representa o se refiere a algo en algún aspecto o carácter. Se dirige a alguien, esto es, crea en la mente de esa persona un signo equivalente, o, tal vez, un signo aun más desarrollado. Este signo creado es lo que yo llamo el interpretante del primer signo. El signo está en lugar de algo, su objeto. Está en lugar de ese objeto, no en todos los aspectos, sino sólo con referencia a una suerte de idea, que a veces he llamado el fundamento del representamen.”, Peirce, Charles Sanders, en: Obra lógico- semiótica, Taurus, Madrid, 1987, p. 22.

28 "La abducción es un instinto que se apoya en la percepción inconsciente de conexiones entre aspectos del mundo...", Sebeok, Thomas A., y Umiker-Sebeok, Jean, Sherlock Holmes y Charles S. Peirce. El método de la investigación, traducción de Lourdes Güell, Paidós, Barcelona, 1987, www.letrae.com, p. 22.
} 
Eliseo Verón ${ }^{29}$, ha distinguido entre objeto inmediato y objeto dinámico. Si el primero se define en un tiempo y un espacio acotado de la semiosis, el objeto dinámico convoca a otros signos que se han referido a él y por tanto, lo desborda:

\begin{abstract}
Siguiendo a Peirce, llamamos al modo de representación del objeto en el signo, el objeto inmediato. Pero el signo no sólo representa su objeto de una cierta manera; también representa su propia relación con el objeto: contiene, de alguna manera, una representación de segundo grado, una representación de la relación entre la representación y el objeto. ¿De dónde viene esta segunda representación? Es impuesta a cada signo particular por el funcionamiento de la semiosis: es precisamente en ese sentido que se puede decir que el objeto determina al signo, pues del hecho de que el signo representa siempre su objeto de una cierta manera, se sigue que el objeto desborda al signo" (Verón, 1993: 118).
\end{abstract}

Por definición, el objeto dinámico permanece inasible en su completitud. De un modo semejante, la filosofía occidental en una de sus vertientes más importantes se ha ido alejando de la inmanencia idealista:

Según Heidegger, en Platón se manifiesta ese desvío en el concepto de verdad que lleva desde la aletheia hasta la veritas. Platón no piensa ya la aletheia como el movimiento del desvelamiento, del "no estar más oculto" del ente, sino que la concibe como idea, o sea, como "visión" del ente ya desvelado (visión de la essentia, diferente de la existentia). La verdad como idea, como "visión", da origen de este modo al problema del conocimiento, de la relación sujeto-objeto, de la adecuación "exacta" entre el ver y lo que se ve, entre el hombre y el mundo, que es también el punto de partida no sólo del pensamiento metafísico-científico-técnico sino también de todo el "humanismo". (Sini, 1985: 90).

Los entes absolutos y originarios (esencia) permanecen al margen de la región intermedia entre el ser y la representación, de modo que resultan incognoscibles; podemos acceder a las operaciones de sentido que le atribuye, ya, el lenguaje como dimensión significante de la semiosis social en el interminable orden primero de los signos posibles como cualidades, de los signos de hecho del orden segundo como existencia que desbordan al signo convencional del hábito, y de las leyes del lenguaje como orden tercero donde se define la simbolicidad humana (Peirce, 1955[1905]; Goodman, 1990).

\footnotetext{
29 "La clausura semiótica", La semiosis social. Fragmentos de una teoría de la discursividad, Gedisa, Barcelona, 1993.
} 


\section{Mediatización y espacios mentales}

Hasta ahora hemos tratado de rebatir la idea de comunicación como finalidad del lenguaje, pero no hemos abandonado una dialéctica de pensamiento regida por la oposición binaria de conceptos. La adhesión a la epistemología de Peirce implica desprenderse del modo de pensar el signo como 'algo' inmaterial que estaría 'en lugar de otra cosa', es decir, como duplicación representacional del objeto.

Comprender el proceso de significación del sentido es concebir a la producción significante como la relación entre tres términos. La definición peirceana de signo, "algo que para alguien representa o se refiere a algo en algún aspecto o carácter" (Peirce, 1955[1905]: 22), no debiera confundirse con el reenvío de la referencia a un mundo estable y fijo -mundo de objetos contrapuesto al de los sujetos-, sino que los signos reenvían a otros signos: los de la percepción humana del mundo, los de sus descripciones en los lenguajes diversos presentes en la semiosis infinita (Fabbri, 2000).

Se trata de concebir a la producción de sentido, a los procesos y sistemas de significación como aquello que forma una de las dimensiones del proceso social del tejido de la semiosis: la dimensión significante de los fenómenos sociales (Verón, 1993).

La aparente ambigüedad de la definición peirceana no se confunde si se tiene en cuenta el marco de referencia de su pensamiento y los correlatos de la primeridad, la secundidad y la terceridad desarrollados en la lógica relacional de las funciones del signo, necesariamente triádico ${ }^{30}$.

Aunque no dejaremos de utilizar el término 'representación' en este trabajo, lo haremos con la idea de que en cualquier representación hay un fragmento de la construcción social de sentido. Adherimos a la circunscripción que realiza Eliseo Verón cuando señala:

Hablar de espacios mentales me parece a la vez más útil y más preciso que hablar de "representaciones", como se hizo durante mucho tiempo en ciencias sociales, por una razón muy simple: la noción de "representación" tiene una dimensión semántica que reenvía inevitablemente al iconismo y a la problemática de la analogía; el concepto de "espacio mental" es, en cambio, totalmente indiferente a las características de las

\footnotetext{
${ }^{30}$ La explicación en detalle de las categorías de Peirce excede nuestro propósito. Pero puede encontrarse bibliografía de referencia en el trabajo ya citado de Carlo Sini (1985) como en el de Gérarde Deladalle (1990), Leer a Peirce hoy, además de las remisiones que hacemos aquí a La semiosis social de Eliseo Veron.
} 
operaciones (primeras, segundas o terceras, para utilizar la terminología de Peirce). Un espacio mental no es otra cosa, por definición, que una configuración de operaciones de los tres tipos ${ }^{31}$.

La construcción de mundos en el pasaje de operaciones primeras, segundas y terceras (estados, procesos y relatos, reglas respectivamente) entre espacios mentales se modifica con el cambio de escala que los medios de comunicación implican como tecnologías -aunque no puedan reducirse sólo a su aspecto tecnológico-, entendidos como "dispositivos de ruptura de escala dentro de la configuración de los espacios mentales de la sociedad" (Verón, 2001b: 106).

En nuestro ámbito, Eliseo Verón describió el fenómeno de la mediatización como:

El resultado de un tal proceso de mediatización sería la transferencia total de las prácticas colectivas al universo de los medios; la vida privada-cotidiana definida, por diferencia, como el conjunto de los campos significantes no mediatizados. (Verón, 2001b: 16).

La irrupción y aceleración de la constitución de los fenómenos mediáticos en el entramado de las sociedades contemporáneas, desde la prensa escrita de masas en el siglo XIX y luego con la radio, el cine y la televisión en el XX, marcó el pasaje de una sociedad industrial mediática al de una sociedad mediatizada:

Una sociedad mediática es una sociedad donde los medios se instalan: se considera que estos representan sus mil facetas, constituyen así una clase de espejo (más o menos deformante, poco importa) donde la sociedad industrial se refleja y por el cual ella se comunica. Lo esencial de este imaginario es que marca una frontera entre un orden que es el de "lo real" de la sociedad (su historia, sus prácticas, sus instituciones, sus recursos, sus conflictos, su cultura) y otro orden, que es el de la representación, de la reproducción y que progresivamente han tomado a su cargo los medios (Verón, 2001b: 14).

En cambio, el imaginario que comienza a emerger en una sociedad mediatizada pone en juego la acción de los medios en la dimensión significante de la sociedad:

Un espacio mental es un paquete de trayectorias en intersección, compuestas de operaciones semióticas primeras, segundas y terceras. La mediatización se fue apropiando de las tres dimensiones de la semiosis y los llamados medios electrónicos

\footnotetext{
${ }^{31}$ El cuerpo de las imágenes, Norma, Buenos Aires, 2001, p. 107.
} 
generalizaron la mediatización de la primeridad y la secundidad y los "efectos" de rupturas de escala (Verón, 2001a: 133).

Entendemos que la distinción entre cambio y ruptura de escala no es excluyente; ambos fenómenos coexisten en el pasaje entre espacios mentales. Si los cambios de escala provocan la mediatización tecnológica,

...la mediatización de las operaciones primeras y segundas, es decir, de las representaciones icónicas y del contacto indicial, produce en cambio lo que llamaremos rupturas de escala. Hablamos de ruptura porque la mediatización de la primeridad y la secundidad introduce en un nivel colectivo operaciones que antes sólo eran posibles en el contexto inmediato de la semiosis interindividual: cuando el susurro pasional del amado en el oído de la amada, es visto en gran plano y escuchado por varios millones de personas, estamos ante un fenómeno de ruptura de escala. Los medios modernos, llamados durante mucho tiempo "de masas", son dispositivos de ruptura de escala (Verón, 2001a: 132-133).

Resta aclarar que al hablar de espacios mentales, "mental no se opone a material; cada soporte material es parte constitutiva, determinante, del tipo de operaciones semióticas que pueden ser investidas en él” (Verón, 2001a: 173).

De esta manera, se reafirma la necesidad de pensar la materialidad del sentido tanto en la capacidad de los dispositivos de imponer restricciones y posibilidades técnicas, cuanto en sus posibilidades y sus restricciones discursivas (Traversa, 2001).

\section{Mundos posibles y cambio de escala}

Los diarios digitales, entre otros medios, constituyen un universo de significaciones en el que se construyen y asientan mundos posibles ${ }^{32}$ de producción de sentido. La sociedad inscribe en ellos espacios de representación compartidos. Se trata, como en todo espacio representacional, de un mundo hecho por una diversidad de lenguajes y constituido en las particularidades de su materialidad técnica y, no menos, significante.

Consideramos que un medio inaugura un universo de significación de relativa autonomía (Luhmann, 2000) respecto de "lo real" cotidiano, es decir, de las semiosis interpersonales (aunque no dejan de establecerse interacciones entre éstas) a partir del proceso descripto como mediatización en las sociedades posindustriales (Hjarvard,

\footnotetext{
${ }^{32}$ Usamos el concepto en un sentido cercano al de Goodman, Nelson, Maneras de hacer mundos, Visor, Madrid, 1990, sin dejar de considerar la importancia que ha adquirido en la lógica contemporánea a partir de las reformulaciones que introdujo Hintikka en la filosofía de Wittgenstein, para esto veáse: Meyer, Michel, "Hintikka o los mundos posibles", Lógica, lenguaje y argumentación, Hachette, Buenos Aires, 1987.
} 
2016; Verón, 2013). De este modo, el medio aparece como superficie operatoria en la que se inscriben espacios mentales:

Cada tecnología se caracteriza por modalidades específicas de transición entre espacios mentales. Cada "soporte mediático" tiene sus trayectorias, cualitativamente distintas de las que caracterizan a otros soportes. Cada tecnología hace posible modalidades de articulación que le son propias entre la primeridad, la secundidad y la terceridad, es decir, entre las impresiones y afectos, los hechos y relatos, las reglas y normas. Si las redes semióticas de espacios mentales se definen como sistemas complejos, eso significa que hay siempre una proporción de azar en las trayectorias, pero que ese azar opera de manera diferente en cada sistema, en cada soporte tecnológico. No es sorprendente entonces que la articulación histórica y progresiva entre las diferentes tecnologías tienda a aumentar la complejidad y a generar mundos más o menos segregados, además de modificar las conexiones entre los mundos existentes. El momento cero es ese momento en que se genera la ilusión de que un solo tipo de conectividad va a producir la integración de todos los mundos, es decir, va a permitir entrar en un mundo." (Verón 2001a: 75, el subrayado es nuestro).

Los dispositivos tecnológicos permiten la mediatización de las prácticas sociales. La mediatización transforma esas prácticas e implica un cambio de escala (Verón, 2001a, 2013) espacial, temporal y en sus modalidades respecto de las semiosis sociales interpersonales y de los dispositivos tecnológicos anteriores, a los que condensa y reconfigura.

En cambio, en las vivencias cotidianas del sujeto, el aparato fonador y la voz, la escritura manual, la gestualidad, adquieren la capacidad de soportar el lenguaje en el сиегро:

Cuando apareció el grafismo, se produjo un nuevo equilibrio entre la mano y la cara (se habían liberado la una al mismo tiempo que la otra, la una a la otra): la cara tuvo su lenguaje (el de la audición y la locución) y la mano el suyo (el de la visión y el trazado gestual). (Barthes, 2003: 98).

En la tentación de llamar a éstos, dispositivos "biológicos", deberíamos conformarnos con denominarlos soportes o dispositivos perceptuales no mediáticos con el fin de evitar una división, dudosa, entre el "mundo social" y el "mundo natural".

De todas maneras, en la mediatización de lo social se construye un cuerpo que figura $^{33}$ comportamientos pero que resulta ajeno al cuerpo biológico: en la mediatización operan cambios de escala tecnológicos, que hacen irreductible la

\footnotetext{
33 Aludimos a la figuración del cuerpo en los medios, tal como entiende el término Oscar Traversa, Cuerpos de papel. Figuraciones del cuerpo en la prensa 1918- 1940, Gedisa, Barcelona, 1997.
} 
comparación de la experiencia sensorial directa con la experiencia distanciada que proponen los medios.

Los soportes tecnológicos crean superficies de inscripción de trayectorias que multiplican la complejidad en la circulación del sentido en el espacio social y que, respecto de los actores sociales, resultan autónomos y autorreferenciales (Luhmann, 2000; Verón, 2013).

\section{El sentido en lo social y lo social en el sentido}

El punto de "contacto" entre la autonomía (Luhmann, 2000) de los soportes tecnológicos que permiten la conservación material de los signos (Verón, 2013, 1993) con los actores sociales se sustenta en una doble hipótesis que considera que todo fenómeno social se inscribe en el lenguaje, pero un fenómeno social no es sólo lenguaje:

Una teoría de los discursos sociales reposa sobre una doble hipótesis que, pese a su trivialidad aparente, hay que tomar en serio:

a) Toda producción de sentido es necesariamente social: no se puede describir ni explicar satisfactoriamente un proceso significante, sin explicar sus condiciones sociales productivas.

b) Todo fenómeno social es, en una de sus dimensiones constitutivas, un proceso de producción de sentido, cualquiera fuere el nivel de análisis (más o menos micro o macrosociológico). (Verón, 1993: 125).

La teoría de la enunciación en sus distintos desarrollos coincide (Benveniste, 2002; Kerbrat-Orechioni, 1997; Ducrot, 2001; Ducrot y Schaeffer, 1998) en separar estas instancias de figuración de un modo no personalizable.

Nosotros retomaremos la propuesta para nombrar a los conjuntos de las materialidades de los signos, el término objetos-textos (Fabbri, 2000; Verón, 1997) como conjuntos constituidos de materias significantes, que en tanto signos y productos culturales circulan y se asientan en los medios, a diferencia de las prácticas sociales no mediatizadas e interpersonales.

El contacto entre dispositivos tecnológicos y actores sociales resulta relativizado por el carácter distintivo de los procesos psíquicos individuales -tal como los describe el psicoanálisis y otras ciencias- en los que las motivaciones inconscientes no son despreciables, pero que además implican cuestionar el supuesto de las teorías representacionalistas y funcionalistas, en la idea de que el lenguaje sirva para comunicar: 
...no es evidente que la escritura sirva para comunicar, si atribuimos a la escritura funciones puramente prácticas de contabilidad, de comunicación, de registro, y censuramos el simbolismo que mueve el signo escrito, es por un abuso de nuestro etnocentrismo. (Barthes, 2003: 93).

Sin embargo, el individuo se transforma en sujeto social, entre otras características, por su encultured knowledge ${ }^{34}$ que para nosotros resulta de su -aunque no sólosocialización en el lenguaje.

\section{La construcción del sujeto en la semiosis}

Es en la dimensión significante de la semiosis social donde se construyen las significaciones del sujeto. El sujeto social, en tanto tal, es ya figura textualizada, construida en la enunciación. No hablamos de la persona. La persona vive, tiene experiencias o vivencias que desbordan al signo. Estas se inscribirán de un modo u otro en el lenguaje, "aun en estados correspondientes a rutinas hipnóticas de descanso" (Verón, 2001a: 12).

El lenguaje condicionará esas rutinas en una materialidad significante designando y asignándoles un conjunto de prácticas y representaciones sociales, es decir, un recorrido de trayectorias en la transición de espacios mentales. La construcción de las significaciones del sujeto en un fragmento de semiosis dependerá de su inscripción en un espacio, en un tiempo y en cierta materialidad del lenguaje social.

De este modo, el sujeto se constituye en objeto del lenguaje ${ }^{35}$, según la proposición de Peirce: “... del mismo modo que decimos que un cuerpo está en movimiento, y no que el movimiento está en el cuerpo, así también debemos decir que estamos en el pensamiento, y no que los pensamientos están en nosotros"36.

El "pasaje" de operaciones y la "autonomía" de los juegos de lenguaje generan la construcción de mundos posibles

Desde el punto de vista de las operaciones sígnicas primeras (cualidades posibles), segundas (de las materialidades existenciales) y terceras (de las convenciones

34 “... conocimiento ligado a la socialidad...", Collins, Harry M. y Kusch, M. The Shape of actions: What Humans and Machines Can Do, Cambridge, MIT Press, 1998, citado en: Op. cit., Verón, Eliseo, Espacios mentales, p. 174.

${ }^{35}$ La metáfora según la cual cada uno de nosotros es un poseído del lenguaje parece pertinente para explicar la posición del sujeto en la semiosis; Verón, Eliseo, “¿Quién sabe?”, Efectos de agenda, Gedisa, Barcelona, 1999, p. 18.

${ }^{36}$ 5.289, nota, según la abreviación habitual de los escritos de Peirce donde el primer número indica el volumen y después del punto, el párrafo. Citado en: Sini, Carlo, Semiótica y filosofía. Signo en Peirce, Nietzsche, Heidegger, Foucault, Ricoeur y Levi-Strauss, Hachette, Buenos Aires, 1985, nota 11 en p. 30. 
simbólicas) que caracterizan la teoría de Peirce, no hay distinción entre un fragmento de semiosis interpersonal y un fragmento de semiosis mediatizada.

Ni siquiera pudiera inducirse algún tipo de determinación entre el "pasaje" de las prácticas interpersonales al conjunto de sus representaciones en los medios, ya que en la semiosis social no-mediática encontramos el mismo tipo de operaciones que en los medios:

... el desfase entre producción y reconocimiento es constitutivo de la comunicación humana, y opera aun en el nivel no mediatizado de la comunicación interpersonal. Se puede inferir, entonces, que la mencionada ruptura expresa la no linealidad de la circulación del sentido, y que los fenómenos mediáticos no son su causa primera. (...) Digamos, por el momento, que los fenómenos mediáticos institucionalizan, multiplican, amplifican, en los niveles más macroscópicos del funcionamiento social, ese desfase constitutivo. (Verón, 2013: 292).

La diferencia radica en el cambio de escala (Verón, 2000a; 2013) que produce la existencia de los medios y los procesos históricos, de transformación social, inscriptos en la mediatización que actúa entre "lo real” social y "lo real” mediático.

Ese cambio de escala, resultado de la mediatización, le otorga autonomía a medios de comunicación como los diarios digitales, en los que se asientan una diversidad de juegos de lenguaje con reglas propias en sus condiciones de producción y en sus condiciones de reconocimiento. De ese modo es posible la construcción de mundos en y de la información periodística de actualidad, entre los que se encuentran las noticias sobre religión.

En tanto "lo real" mediático pasa a formar parte también de las prácticas y representaciones sociales puede sostenerse la construcción de lo social en los medios, tanto como la construcción de los medios en lo social haciendo ostensible la doble hipótesis a la que hacíamos referencia (Verón, 1993).

Entonces, la autonomía de un medio de comunicación funciona respecto de: a) la consciencia de los actores sociales y sus intenciones, deseos o motivaciones, y b) en cuanto a la especificidad de su materia significante y de su lógica en el sistema de los medios, en el cual interactúa, en el campo de las prácticas sociales específicas de representación asociadas a cada medio.

Lo que llamamos "comunicación" -si es que vale la pena insistir en el términosólo puede establecerse, pues, como hipótesis de producción o hipótesis de reconocimiento entre operaciones relacionales del lenguaje o, en las relaciones entre 
máquinas con códigos inequívocos y distintos a la polisemia del sentido que predomina entre los actores sociales.

Barthes (1987: 68) ha dicho esto refiriéndose a la escritura: “...el lenguaje conoce un "sujeto", no una "persona", y ese sujeto, vacío excepto en la propia enunciación, que es la que lo define, es suficiente para conseguir que el lenguaje "se mantenga en pie”, es decir, para llegar a agotarlo por completo”, y más adelante aclara que:

... el escritor se limita a imitar un gesto siempre anterior, nunca original; el único poder que tiene es el de mezclar las escrituras, llevar la contraria a unas con otras, de manera que nunca se pueda uno apoyar en una de ellas; aunque quiera expresarse, al menos debería saber que la "cosa" interior que tiene la intención de "traducir" no es en sí misma más que un diccionario ya compuesto, en el que las palabras no pueden explicarse sino a través de otras palabras, y así indefinidamente (Barthes, 1987: 69).

La especificidad en que se articulan los dispositivos técnicos con sus particulares usos sociales por parte de una comunidad cultural traza trayectorias de operaciones sígnicas que configuran las memorias de una sociedad, pero también sus olvidos.

\subsection{Antropología, tecnología y comunicación}

Hasta aquí hemos hecho un recorrido por la presentación conceptual de las herramientas teóricas que alimentaron el análisis semiótico, en la concepción del lenguaje con la que trabajamos, a partir de la epistemología peirceana.

Ahora nos proponemos abordar la relación sociohistórica entre algunos desarrollos conceptuales de la antropología y las ciencias humanas para describir, desde el punto de vista histórico, las transformaciones sociales que desembocaron en el proceso que llamamos mediatización.

Este recorrido bibliográfico o "estado del arte" también pretende articular las nociones conceptuales que han proliferado con las llamadas "nuevas tecnologías de comunicación" al reconectarlas con algunas de las reflexiones antropológicas que consideramos de gran poder explicativo para abordar las diversas tecnologías que alimentaron a los medios de comunicación.

De este modo, reconocemos preocupaciones teóricas compartidas en la herencia conceptual de Claude Lévi-Strauss, Roman Jakobson, Norbert Wiener y más cerca en el tiempo Margaret Mead, Gregory Bateson, Erving Goffman, Jack Goody, 
Clifford Geertz, Paul Watzlawick, entre otros teóricos de las ciencias sociales.

Artes, técnicas y medios

Estudiosos de la historia y de las lenguas clásicas (Havelock, E. A., 2008, Chartier, 2008, Einsenstein, 2010) y, en particular, antropólogos (Goody, J., 1996 [1968]), han hecho notar a quienes trabajamos de manera interdisciplinaria en el horizonte de las teorías de la comunicación, que nuestra problemática $-\mathrm{y}$ la de los medios- remonta su conflictividad, al menos, hasta las dataciones difusas de la capacidad de habla y lenguaje de las agrupaciones sociales de seres humanos (Verón, 2013).

En su libro La musa aprende a escribir Eric A. Havelock (2008) se propone, según enuncia al principio de su obra:

La intención que se persigue con este libro es presentar un cuadro unificado de una crisis que se produjo en la historia de la comunicación cuando la oralidad griega se transformó en la civilización de la escritura griega. (Havelock, 2008: 21, el subrayado es nuestro).

Roland Barthes (1989) incluye a los grafismos pictóricos y las marcas territoriales en el origen de la escritura y del arte:

Conviene repetir una vez más que en el origen conjunto de la escritura y del arte hubo ritmo, el trazado regular, la simple puntuación de incisiones in-significantes y reiteradas: los signos (vacuos) eran ritmos y no formas. Lo abstracto es en su origen grafismo, la escritura es en su origen arte (Barthes, 1989: 74).

Esta perspectiva nos permite pensar las relaciones entre medios y sociedad no sólo como resultado de un cambio tecnológico ni como una característica propia de la época actual.

Por el contrario, sus configuraciones provienen de procesos complejos de larga data en los que, a los momentos de la invención, la adaptación y la adopción, se suman las reconfiguraciones que en y con los usos sociales generan prácticas, representaciones y discursos, en la dinámica social que tiene particularidades históricas y geográficas -en las que incluso sus definiciones permanecen en estado cambiante.

Nos parece importante situar en breve el marco de esas discusiones, que traen consigo una serie de problemas tanto en torno a las teorías de la comunicación como en cuanto a las prácticas de significación y producción social de sentido. 


\section{La mirada antropológica}

Jack Goody e Ian Watt (1996 [1968]) han destacado la "revolución" que significó el pasaje de sociedades tradicionales a sociedades con escritura:

La noción de representación de un sonido mediante un símbolo gráfico es en sí misma un salto tan asombroso de la imaginación que lo notable no es que se haya producido en un momento relativamente tardío de la historia de la humanidad, sino que de hecho haya llegado a producirse. (Goody y Watt, 1996 [1968]: 49).

Esa "revolución" situada de manera canónica en la Grecia del siglo VII a. de C., se basó en la adopción y adaptación del alfabeto fenicio el que, tras un largo período de difusión de la lecto-escritura ${ }^{37}$, resultó en una puesta a punto de una "tecnología del intelecto" (Goody, J., 1996 [1968]: 21) capaz de articular las capacidades simbólicas (Cassirer, E., 1967 [1944]), en apariencia propias, de la especie humana e innatas a nuestra especie biológica según Noam Chomsky $(1998)^{38}$.

Así, el registro de la memoria, la expansión imaginativa en la ficción y la representación del sonido del habla -aunque no su traducción lineal- fueron potenciados y reconfigurados por la escritura alfabética. Además, este tipo de escritura posibilitó otras prácticas, representaciones y fenómenos sociales, entre los que pueden mencionarse el principio de individualización (Havelock, E. A., 2008, volveremos más adelante sobre esto), el concepto de pasado, el escepticismo, la acumulación de conocimiento y las tradiciones críticas (Goody, J., y Watt, I., 1996 [1968]).

Por supuesto, la escritura también constituye una de las formas tecnológicas de acceso -y de registro- a los signos lejanos del tiempo ${ }^{39}$, que comparte con las prácticas y técnicas de la momificación y estatuaria egipcias, el ansia humana de vencer a la

\footnotetext{
${ }^{37}$ Según Havelock, E. A. (2008: 21): "La literatura y la filosofía griegas representan empresas gemelas de la palabra escrita, las primeras de su género en la historia de nuestra especie. Por qué exactamente fueron las primeras, y en qué consistía precisamente su unicidad, son preguntas cuya mejor respuesta se encuentra en el contexto de lo que se ha llamado la revolución alfabética griega", y el mismo autor agrega: (...) "Los griegos no <<añadieron las vocales >> (un error frecuente: los signos vocálicos habían aparecido en el cuneiforme mesopotámico y el Lineal B) sino que inventaron la consonante (pura). Y con ello proporcionaron a nuestra especie por primera vez una representación visual del ruido lingüístico que era a la vez económica y exhaustiva: una tabla de elementos atómicos que agrupándose en una variedad inagotable de combinaciones pueden representar con exactitud razonable cualquier ruido lingǘstico efectivo. El invento suministró también el primer y último instrumento que estaba perfectamente construido para reproducir el entero alcance de la oralidad previa." (ibídem, p. 97).

${ }^{38}$ Michael Tomasello (2013) discute la hipótesis del innatismo. Tras un largo estudio del comportamiento de chimpancés llega a la conclusión de que el hombre tiene una comunicación cooperativa, producto del aprendizaje socializado.

${ }^{39}$ La paráfrasis es de una frase de Oswald Spengler: "La escritura es el gran símbolo de lo lejano", citado en Goody, J., (1996 [1968]: 65).
} 
muerte y perdurar en el tiempo (Bazin, 1990) que provoca la comunión entre representación y creencia mágico-religiosa ${ }^{40}$.

La identificación de un "público", con la oratoria retórica hacia el auditorio y con el intercambio oral, se ampliaba bajo las capacidades de la lectura y la escritura. Sus fragmentaciones y multiplicaciones en el paradigma modernista (Bell, 1976; Huyssen, 2002) y, en particular, con el cambio tecnológico que provoca la difusión de internet, pone en jaque la relación con los medios mal llamados "masivos" -en los que el carácter de su masividad se encuentra en tela de juicio, aunque no sólo por la aparición de las nuevas tecnologías ${ }^{41}$.

\section{Sociedades, tecnologías, lenguajes}

Cuando las sociedades comenzaron a utilizar grafismos, el registro de lo que luego sería la escritura empezó a insistir en su existencia sobre soportes de “comunicación” materiales y autónomos respecto al cuerpo del sujeto (Verón, 2013; Chartier, 2008).

Desde las tablas sumerias de escrituras diagonales, hasta las imágenes trucadas de la primera guerra transmitida "en directo" por la cadena televisiva CNN sobre la Guerra del Golfo el 17 de enero de 1991, no es evidente que los lenguajes, los signos y los medios hayan servido para comunicar -como dijimos antes respecto a la noción de comunicación. Muy por el contrario, han sido utilizados tanto para ocultar como para "comunicar" un supuesto contenido de "mensajes" a los que se asigna una pretendida transparencia: la de la ilusión representacional (Greimas, A., 1991: 136; Recanati, 1981; Marin, 2015 [1977]).

En la insistencia sobre la importancia de la revolución alfabética que reencontramos actualizada en la llamada "revolución electrónica" (Dorce, 2009: 15), a veces se suma una explicación reduccionista sobre los procesos de intercambios simbólicos humanos resumidos bajo el término comunicación:

\footnotetext{
${ }^{40}$ Con referencia a la fotografía, y aunque nosotros extendemos la afirmación al acto de representar como hecho que, en su doble fantasmagórico, crea el objeto existente, Bazin señala: “... nos vemos obligados a creer en la existencia del objeto re-presentado: hecho presente en el tiempo y en el espacio", Bazin, A. (1990), "Ontología de la imagen fotográfica".

${ }^{41}$ Ya Havelock (2008: 50) destacaba que: "Están actuando ciertas fuerzas que, al parecer, lo empujan hacia el nivel del reconocimiento consciente, obligándonos a mirarnos a nosotros mismos, por un lado, como escritores y lectores, pero, por otro, también como seres que actúan y escuchan; papel éste que las nuevas tecnologías de la comunicación están resucitando para nosotros y se diría que incluso nos lo imponen. Antes de ocuparnos de la historia griega, podría parecer conveniente examinar el contexto moderno dentro del cual la historia emerge.".
} 
Afirmar, como lo hace la mayor parte de los historiadores y arqueólogos, que la función originaria de la escritura (el motivo por el cual fue inventada) fue muy evidentemente la $<<$ comunicación $>>$, suscita mucho embarazo y no poca perplejidad: si se trata de $<<$ comunicar $>>$, naturalmente del modo más claro y rápido posible, ¿cómo explicar el hecho de que algunos pueblos (los sumerios, los acadienses) inventaran escrituras $<<$ abstractas dificiles $>>$, (la cuneiforme, por ejemplo), mientras que el pictograma, que se considera el antecedente, era $\tan <<$ claro $>>$. En estos interrogantes se encuentran proyectados muchos valores tal vez enteramente modernos: la buena comunicación, la claridad, la eficacia, la abstracción: el escriba mesopotámico del III milenio tenía las mismas necesidades, las mismas cualidades que el secretario de dirección de una empresa capitalista. (Barthes, 1989: 23).

La concepción moderna de la escritura valorada como bien absoluto, democratizador y de progreso se opone a lo que Barthes llama su "verdad negra": la utilización de la escritura como pertenencia de clase, como marca de la propiedad privada y de la distinción en el estilo y la caligrafía:

...la escritura, históricamente, es una actividad continuamente contradictoria, articulada sobre una postulación doble: por una parte, es un objeto estrictamente mercantil, un instrumento de poder y de discriminación, una expresión de la más cruda realidad social; por la otra, un medio de goce, ligado a las pulsiones más profundas del cuerpo y a las manifestaciones más sutiles y más afortunadas del arte. (Barthes, 1989: 12).

Nos interesa señalar cómo el mismo término "comunicación" ha representado un papel histórico y otro reciente en nuestras concepciones sociales: desde comienzos del siglo XX, la comunicación remite también a una disciplina y al conjunto de sus teorías. Es para nosotros -como vimos en el apartado anterior- uno de sus sentidos difusos, ya que la disciplina de estudio pretende abarcar a su objeto al confundirse con él ${ }^{42}$.

De manera histórica, el cambio técnico hizo posible la invención de la imprenta y la difusión de la cultura escrita, en conjunción con las búsquedas del paradigma modernista. En particular desde la concepción difundida por el Iluminismo y su proyecto enciclopedista, la educación, la alfabetización y los primeros medios de

\footnotetext{
${ }^{42}$ Es el modus operandi de la ideología representacional: el objeto designado es confundido con el signo que lo designa, y del cual notamos sus consecuencias enmascaradas en el determinismo tecnológico. Una crítica que nos parece interesante es la expuesta por Dominique Wolton (2000), quien señala respecto a esa discusión: "Hoy en día, la frase principal podría ser: sí a la comunicación como objetivo teórico; no a la comunicación como ideología", (Wolton, 2000: 21).
} 
"comunicación" que se consideraron dirigidos a las sociedades de "masas"43, con la incipiente prensa gráfica del siglo XVIII, y que debían servir para comunicar al conjunto de los 'ciudadanos capaces de formar opinión pública'44.

No era el conjunto de la sociedad toda, la involucrada en esta categoría de ciudadanía y opinión pública; desde ya, sabemos por los documentos e investigaciones históricas (Sennet, 1978; Habermas, 1981; Eagleton, 1996; Darnton, 2000; Chartier, 2008 entre otros) que quedaban excluidos aquellos sectores considerados improductivos o marginales de la sociedad: ancianos, niños, disminuidos, pero también en gran medida, los sectores obreros trabajadores en las minas de carbón de la Inglaterra del siglo XVIII y XIX, o incluso en la América independentista y en la Francia pos-revolucionaria.

Resulta de especial interés que en gran medida estos sectores formarán parte luego de las temidas 'sociedades de masas' de principios del siglo XX y constituirán al público del cinematógrafo como los testigos aficionados de la "democratización" de las imágenes, con la difusión cultural y técnica de la fotografía, interpelados luego por la radio y la televisión (Sorlin, 2004).

Es entonces el carácter lineal y secuencial de la concepción racionalista el que describe a la escritura como transcripción del habla y de la expresión intencional del individuo (Barthes, 1989; Dennett, 1995). El mito cientificista de una escritura lineal, informativa y transparente que se potencia con el mito moderno del origen de la escritura en su función de comunicar las intenciones de los sujetos hablantes:

\footnotetext{
${ }^{43}$ Con una peyorativa concepción de la cultura de masas, término que utilizaron Adorno y Horkheimer en los borradores de su libro Dialéctica del Iluminismo y que luego fue reemplazado por el no menos despectivo de "industria cultural".

${ }^{44}$ Como señala J. Martín Barbero: "La formación comunicativa inicial de la "esfera pública burguesa" ha sido planteada por J. Habermas como la emergencia de un nuevo modo de asociación no vertical como el que se forma desde el Estado- y del que hacen parte originariamente sólo los que tienen instrucción y propiedad. Un siglo después la esfera pública es redefinida por la presencia de las masas urbanas en la escena social, cuya visibilidad remite a la transformación política que, de un asunto de Estado, pasa a convertirse en "esfera de la comunidad, la esfera de los asuntos generales del pueblo". De otro lado, la visibilidad política de las masas va a responder también a la formación de una culturapopular-de-masa: los dispositivos de la massmediación articulan los movimientos de lo público a las tecnologías de la fábrica y del periódico, al tiempo que la aparición de la rotativa, ampliando el número de ejemplares impresos, abarata los costos y reorienta la prensa hacia el "gran público". La publicidad, en el sentido habermasiano, va a conectar entonces dos discursos: el de la prensa que ensambla lo privado en lo público a través del debate entre ideologías y la lucha por la hegemonía cultural; y el de la propaganda comercial que trasviste de interés público las intenciones y los intereses privados. A caballo entre ambos discursos se produce el desdoblamiento que lleva de lo público al público que conforman los lectores y los espectadores de las diversas manifestaciones culturales. Es entonces cuando hace su aparición la figura más plenamente comunicacional de lo público: la opinión pública." (Martín Barbero, J., 2002).
} 
Producto de la actividad humana, la lengua comparte con ésta el carácter de finalidad. Cuando se analiza el lenguaje como expresión o como comunicación, la intención del sujeto hablante es la explicación que se presenta más fácilmente y que es la más natural. También se debe prestar atención, en el análisis lingüístico, al punto de vista de la función. Desde este punto de vista, la lengua es un sistema de medios de expresión apropiados a un fin. No se puede comprender ningún hecho de lengua sin tener en cuenta el sistema al que pertenece (declaración del Círculo Lingüístico de Praga en el Primer Congreso de Filólogos Eslavos, citado en: Verón, 1993: 93).

Esta exaltación de la expresión subjetiva -que en las artes visuales del cine y la pintura dio nacimiento al estilo expresionista-, en la escritura pone en escena uno de los aspectos en que las tendencias modernizantes y tecnológicas coinciden: la acentuación del proceso de individualización.

\section{El largo proceso de individualización}

Desde que las sociedades humanas entran en el proceso denominado logocentrismo (Chartier, 1992; Havelock, 2008) difundido por las prácticas de la escritura y la lectura, la construcción de la experiencia social y su memoria cambia.

El grupo era fundamental en esa construcción para las sociedades tradicionales con escritura restringida: el relato de la experiencia era transmitido por contacto directo en un "proceso homeostático" (Goody y Watt, 1996 [1968]: 42-43), es decir, de selección y transformación de una memoria social de alcance limitado.

En cambio, con “... el descubrimiento de la individualidad (selfhood) se podía considerar parte y parcela de aquella separación entre el conocedor y lo conocido que la creciente difusión de la capacidad de leer y escribir favorecía" (Havelock, 2008: 26). Según Havelock, los medios llamados de comunicación masiva han acrecentado las tendencias logográficas:

Los medios electrónicos a los que hemos prestado atención desde la Primera Guerra Mundial no nos han devuelto, sin embargo, a aquella oralidad primaria ni jamás podrían hacerlo. Al lado y por debajo del mensaje acústico se oculta todavía el mensaje escrito. La oratoria de Hitler era seguramente en parte obra de la improvisación. Era genuinamente oral; pero se apoyaba en alguna preparación previamente escrita, y habitualmente había un suplemento escrito que la hacía disponible para responder una vez el discurso se había acabado de pronunciar, con el fin de situarlo en la memoria, por momentánea que fuese. La tecnología misma de la transmisión era hija del alfabeto, de la escritura de las definiciones documentadas y los manuales impresos." (Havelock, E. A., 2008: 62, el subrayado es nuestro).

Reencontramos en los procesos de digitalización de las "nuevas tecnologías infocomunicacionales" la encodificación lineal y simbólica de la programación 
informática (otro lenguaje) en ceros y unos, junto con el principio alfabético de la letra de molde, o tipo móvil, que permitió la reproducción mecánica de la escritura y su difusión masiva en libros, panfletos, estampas y diarios con la imprenta gutembergiana (Ivins, 1975; Darnton, 2000; Eisenstein, 2010).

El largo proceso de individualización se conjuga en los medios con la conformación de los sujetos sociales como parte de públicos capaces de transformarse de lectores en espectadores, contempladores, oyentes, cinéfilos, en audiencias televisivas, consumidores, usuarios e internautas:

La convergencia digital de las industrias editoriales y audiovisuales creó estructuras interrelacionadas para la producción de textos, imágenes y todo tipo de mensajes que se van integrando en la televisión, la computadora y el celular. Consecuentemente, los hábitos culturales se han ido adaptando a esta convergencia de medios: vemos en la pantalla televisiva o de la computadora lo que antes sólo encontrábamos en los cines, en los diarios y libros, escuchábamos por teléfono y en equipos de música o conocíamos al asistir a museos y salas de concierto. La convergencia digital y la consiguiente integración multimedia nos integran en un mismo acto como lectores, espectadores e internautas. (García Canclini, N., 2009: 279).

Para el teórico Néstor García Canclini el proceso de la convergencia acentúa la pérdida de la autonomía (moderna) del campo de las artes: los cambios y relocalizaciones del sujeto en la contemporaneidad son múltiples y los grados de su participación plantea serios problemas a las teorías sociales y comunicacionales contemporáneas.

\section{Divergencias sobre la convergencia mediática: de los públicos a los usuarios}

Sería fácil conectar conceptualmente el complejo proceso de individualización que se desarrolla desde hace más de dos milenios en la cultura occidental y cuya importancia tiende a ser identificada cada vez más, desde diversas corrientes de las ciencias sociales, con la noción de 'usuario' que comienza a utilizarse en los estudios y discursos sobre las Nuevas Tecnologías Info-comunicacionales.

Nos parece que postular tal conexión sería reproducir la ideología representacional y la ideología técnica que, desde la publicidad, la mercadotecnia o la tecnófila exaltación por la tradición de lo nuevo (tradición que no deja de ser modernista: Rosenberg, 1968; Calinescu, 1991) es asumida en discursividades sobre las formas tecnológicas que reducen la complejidad de los fenómenos sociales.

Porque frente a los medios tradicionales el sujeto social no fue ni es un sujeto pasivo. Los cambios que introduce la "convergencia" mediática y su integración 
multimedial en los procesos de digitalización de textos, imágenes, sonidos, palabras, en la mediatización representacional de los espacios públicos y de los sujetos sociales, no son absolutamente novedosos: esos cambios ya habían comenzado en los medios tradicionales y sus prácticas, representaciones y hábitos continúan bajo las nuevas configuraciones en el entorno informático ${ }^{45}$.

Sin menospreciar las diferencias que la invención, adaptación y adopción de internet plantea en sus materialidades técnicas, corporales, espaciales, temporales y narrativas, nos interesa destacar que el hecho de la transposición al entorno informático de soportes, medios y discursividades previas, genera un primer cambio tangible: el de los procesos de encodificación digital en bytes que cambia la reproducción mecánica y/o analógica de las materialidades de la producción, circulación y reconocimiento de sonidos, imágenes y palabras.

En gran medida la convergencia es por una parte mediática: son los "viejos" medios (diarios, revistas, radios, libros, canales televisivos, etc.) los transpuestos al "nuevo" entorno informático de internet; pero por otra parte, la convergencia es cultural:

\begin{abstract}
Jenkins define a la convergencia cultural como: "La explosión de nuevas formas de creatividad en las intersecciones de varias tecnologías mediáticas, industrias y consumidores. La convergencia mediática acoge una nueva cultura folklórica participativa al dar a la gente promedio las herramientas para archivar, comentar, apropiar y recircular contenido. Compañías astutas explotan esta cultura para generar lealtad en sus consumidores y generar contenidos de bajos costos. La convergencia mediática también estimula la narración transmedial, el desarrollo de contenido a lo largo de múltiples canales. (...) Los consumidores están aprendiendo a usar las TIC para incrementar su control sobre el flujo mediático y para interactuar con otros usuarios". (Jenkins, 2001: 93, citado en: Dorcé, 2009: 15).
\end{abstract}

Una de las diferencias específicas, en la descripción teórica citada, pareciera estar marcada por el carácter participativo de los "usuarios". La distinción entre los momentos de la emisión y de la recepción, que fueron los polos del esquema de base

\footnotetext{
${ }^{45}$ Estamos de acuerdo con A. Dorcé cuando afirma: “... el desarrollo histórico de los estudios sobre comunicación, cultura y recepción mediática han probado persuasivamente que el consumo cultural mediático (1) no es pasivo en ningún momento, (2) que los sentidos, significaciones e interpretaciones se producen en el encuentro lector/texto dentro de contextos culturales y situaciones sociopolíticas concretas (el hogar, el barrio u otros espacios públicos); (3) que la actividad del consumidor no se reduce a presentar lecturas oposicionales, negociadas o dominantes de los textos mediáticos, en la medida en que éstas (junto con su nivel de coherencia y potencial contradicción) son determinadas y alteradas parcialmente por categorías identitarias complejas definidas por el género, la edad, la raza/etnia y la clase; $\mathrm{y}$, (4) que tales lecturas potenciales son a su vez producidas por los lectores/consumidores y socializadas (negociadas, impuestas o pugnadas) dentro o fuera de sus comunidades interpretativas utilizando diversos soportes." (Dorcé, A., 2009: 25).
} 
de las primeras teorías comunicacionales, se patentiza como obsoleta con internet. Es cierto, pero también lo es que los conceptos de emisor y receptor ya habían sido reformulados por muchas otras teorías que postularon la no linealidad y el intercambio posicional de los momentos de la producción y la recepción (Jensen y Rosengren, 1997).

Las audiencias contemporáneas, navegan ven, usan, consumen y producen medios (...) ya no sólo están "frente" a los medios. Son una especie de habitantes de una cinta de Moebius: están tanto adentro como afuera. Pueden ser asiduos consumidores dependientes y a la vez trastocarse en productores activos [cooperativos y también operativos]. Cuando decimos operativamente, nos referimos a que más allá de la perspectiva de abordar a las audiencias tradicionales como sujetos activos, que usan los medios de diversas maneras, también empezamos a encontrar que esa actividad se trastoca en productividad" (Cabrera Paz, 2004: 6, citado en: Dorcé, 2009: 20).

En el recorrido bibliográfico se destaca el aspecto participativo de los "nuevos" usuarios tecnológicos:

En resumen, todos los datos convergen en nosotros, los usuarios (de Kherchove, 2006). Los usuarios somos la convergencia, el punto que activa y crea la tecno-red. En la era del web social el usuario es el contenido (Musser y O'Reilly, 2006), el usuario busca al usuario, el usuario busca la información, la información es el usuario, el sujeto es el mensaje. Es la práctica masiva del ver y del mostrar (...) La intimidad se transforma en objeto de consumo y de placer (Cabrera Paz, J., 2009: 265-267 citado en: Dorcé, A., 2009). Las redes sociales novelizan los relatos de vida cotidiana. (ibídem, p. 269).

Podríamos preguntarnos si acaso antes no fue así. Creemos que en el placer que encuentra una televidente al narrar a otros la trama de su telenovela favorita (Martín Barbero, 2002: 8; Orozco, 2001:) también se haya presente una compleja producción social de sentido. Coincidimos con Manuel Castells cuando señala:

Son nuestras mentes $-\mathrm{y}$ no nuestras máquinas- las que procesan la cultura, sobre la base de nuestra propia existencia. La cultura humana existe en y por las mentes humanas, generalmente conectadas a los cuerpos humanos. Por tanto, si nuestras mentes tienen la capacidad material de acceder al ámbito global de las expresiones culturales, seleccionarlas y recombinarlas, entonces sí podemos decir que existe el hipertexto: el hipertexto está dentro de nosotros mismos. O, más bien, está en nuestra habilidad interna para recombinar y asimilar en nuestras mentes todos los componentes del hipertexto, que están distribuidos en diversos ámbitos de la expresión cultural. Internet nos permite hacer exactamente eso. No los multimedia, sino la interoperatividad basada en Internet, que nos permite el acceso y la recombinación de toda clase de textos, imágenes, sonidos, silencios y vacíos, incluido todo el ámbito de la expresión simbólica contenido en el sistema multimedia [convergente], utilizando Internet como medio de llegar a todos nosotros; más bien es algo que nosotros mismos 
producimos al utilizar Internet. (Castells, 2001: 258-9, citado en: citado en Dorcé, A., 2009).

Para cerrar este capítulo nos gustaría retomar las afirmaciones de Jack Goody y Ian Watt que en el estudio antropológico de la cultura escrita en sociedades tradicionales, nos evidencian de una mirada dislocada respecto a las tendencias teóricas en nuestro propio campo de estudios:

Incluso dentro de una cultura escrita, la tradición oral -la transmisión de valores y actitudes en el contacto personal- sigue siendo la principal modalidad de orientación cultural y, en grados variables, está aparte de las diversas tradiciones escritas. En algunos aspectos, esto quizá sea afortunado. La tendencia de las modernas industrias de comunicaciones de masas a promover, por ejemplo, ideales de consumo conspicuo que no pueden ser alcanzados más que por una proporción limitada de la población, bien podría tener consecuencias mucho más radicales de no ser por el hecho de que cada individuo que se ve sometido a esas presiones es también miembro de uno o más grupos primarios cuya conversación oral probablemente sea mucho más realista y conservadora en cuanto a su tendencia ideológica: los medios masivos no son las únicas influencias sociales, y tal vez ni siquiera sean las principales, en la tradición cultural contemporánea en su conjunto." (Goody, J., y Watt, I., 1996 [1968]: 67-68).

Consideramos que es la tradición modernista de la exaltación por la novedad, la que concluye en su traición con la promesa tecnológica, tal vez, porque forme parte de su relato circular y autorreferencial en la Modernidad tardía (Calinescu, 1991).

Hemos tratado de dirigir nuestra indagación respecto a las limitaciones en torno a las tecnologías, sus usos y significaciones sociales, en las que la traición modernista sigue siendo parte de sus relatos del pasado pero vueltas a presentar en formas discursivas y tecnológicas, como novedades. 


\section{PRESENTACIÓN ANALÍTICA. Los enfoques para el análisis empírico}

Los acontecimientos relativos a los fenómenos de religiosidad que los medios seleccionan en diversos espacios de la vida social argentina forman parte de la temática que nuestro objeto de estudio propone abordar en sus reconstrucciones por los medios como informaciones periodísticas de actualidad, en el período 2001-2010.

Esos acontecimientos suelen postular algún tipo de interés social, bajo criterios que le brindan importancia a la "actualidad" y al "presente", y ese interés social por supuesto dependerá de los parámetros de selección (Rodrigo Alsina, 1993: 81) de cada medio, por lo general, definidos en su "posición" o línea editorial, para su conocimiento público en el espacio social.

Celebraciones, procesiones, reuniones, declaraciones, festividades, colectas, entre otras actividades, forman parte del material noticiable en la continuidad del flujo informativo de los medios, siempre y cuando los medios lo transformen en noticias ${ }^{46}$.

Los acontecimientos sobre fenómenos de religiosidad son del tipo de "noticias previsibles" -pese a la paradoja- en que prevalecen todavía los ritmos cíclicos de la sociedad: la religiosidad forma parte de la vida social y sus acontecimientos producen novedades esperadas o "expectativas de novedad” (en el sentido de Bajtín, 1982).

Los medios y las agencias de noticias necesitan producir y disponer de insumos informativos en forma regular para alimentar en cada jornada su caudal informativo y publicar noticias sobre acontecimientos deportivos, medidas de gobierno, acontecimientos políticos y económicos ${ }^{47}$, entre otros.

Por un lado los temas de las agendas de noticias son reconocibles socialmente. Entre esos temas, las formas noticiosas de la religiosidad son parte de la vida cotidiana de nuestra sociedad; por otro lado, los medios abordan recortes, fragmentos, selecciones de relatos de la vida social para su puesta en escena mediática y cada uno de esos

\footnotetext{
${ }^{46}$ Esta aparente paradoja autorreferencial por la que los medios no pueden tratar ningún acontecimiento que no hayan considerado ya en términos de noticia y, que una noticia sea en definitiva una información de los medios, es trabajada con gran perspicacia por Niklas Luhmann (2000) y como no es el objetivo de este trabajo no podemos hacer más que algunas referencias a las problemáticas que involucra, en especial para las consecuencias de la mediatización (Verón, 2013; Hjarvard, 2016).

${ }^{47}$ En una entrevista con María Esther Vázquez, Borges se mofaba de la necesidad de noticias para los medios quienes todos los días tenían que publicar o "inventar" novedades -según el escritor-, y así también extendía su razonamiento a la publicidad que requería autofestejarse en su anuncio (Borges, sus dias y su tiempo, Javier Vergara, Buenos Aires, 1984).
} 
fragmentos se vuelve "representativo" a modo de muestra, de ejemplificación, de lo que sucede en la vida social.

Sin embargo, el proceso de la mediatización (Verón 1997, 2013) convierte esa representatividad en algo ilusorio: la multiplicación y el alcance de los medios de comunicación desborda la concepción representacional mediática y su carácter de muestra se vuelve, al menos, banal (Goodman, 1990, 1995).

El afán de nuevos temas, la producción incesante de noticias, hacen que la vida social esté disponible para la previsibilidad de los textos mediáticos. Tenemos así una existencia de los textos previos, los pre-textos que permiten la circulación pública y social de los textos de los medios (Steimberg, 1993, 2013; Diéguez, 2011).

A esa transformación que produce la existencia de los medios y su acción sobre la sociedad, la llamamos mediatización (Verón, 1997): cuando implica el cambio de escala de un acontecimiento en su pasaje de la vida social, a la vida pública de los $\operatorname{medios}^{48}$.

A continuación comenzaremos a postular el abordaje de las informaciones periodísticas que construyen la actualidad acerca de los fenómenos religiosos.

\subsection{Notas introductorias al análisis de las informaciones periodísticas relativas a lo religioso en clarin.com (CL.com), lanacion.com (LN.com) y pagina12.com (P12.com)}

Entre los diarios digitales seleccionados para nuestra indagación, Pagina12.com fue el que mantuvo una semejanza mayor entre la edición digital y la edición impresa. Por la noche, después de las 24 horas, P12.com publicaba la "edición impresa" en la edición digital $^{49}$.

\footnotetext{
${ }^{48}$ Esa reconfiguración o reconstrucción cotidiana (Steimberg, 2013: 247-267) sucede también en un sentido inverso, es decir de la subjetividad hacia los medios, con el "criterio empírico del despertar" (Schopenahuer, 2004 [1819]: 58) y su pasaje de la vida de los sueños, al relato del sueño (Steimberg, 2013: 247-267) y la entrada en los géneros de la vida social, entre los cuales se encuentran los de los medios.

${ }^{49}$ Estas características han cambiado en los sucesivos rediseños digitales de este medio, en especial, en 2016. Según la entrevista que realizamos al periodista especializado en religión Washington Uranga, este cambio se produjo a partir de la coordinación de la edición digital del diario por parte de la periodista Nora Veiras.
} 
Esta paradoja de la edición digital que subsume a la "impresa" es imposible en su sentido literal ya que el papel nunca podrá estar presente en el entorno informático digitalizado. La clasificación es posible, en cambio, como efecto de lo que podemos llamar con Gérard Genette (1989) transposición mínima: lo que hace P12.com es publicar en la portada digital de su sitio web una simulación visual de la "tapa" de la edición impresa, con la posibilidad de ingresar en la noticia y leerla.

Con el transcurso de las horas suele reacomodar este recuadro de la "tapa" así como las informaciones principales hasta que por la tarde, a veces apenas pasado el mediodía, actualiza las noticias de acuerdo a la importancia y urgencia que le otorgue el medio. Esta paradoja y sus remisiones a lo impreso se encuentran presentas ya, desde el isologo de Página12.com, que reenvía en similaridad metafórica a la tipografía de una máquina de escribir:

\section{Páginal12 \\ 4 Jueves, 29 de Mayo de 2008 | 16:21}

Aunque se diferencia al reemplazar la tradicional barra en diagonal que separa el número doce de la edición en papel por una barra roja en la edición digital; debajo hay dos triángulos interactivos que permiten recorrer, en el tiempo, el archivo del diario digital. A su vez, entre los espacios publicitarios de portada, un recuadro remite a través de un hipervínculo al diario brasileño Carta Maior y, al final, la página web aclara que el sitio ha sido desarrollado con software libre GNU/Linux. 
Páginal12

\section{4) Lunes, 06 de mayo de 2013 | $14: 52$}

ULTIMAS NOTICAS EDICIONIMPRESA

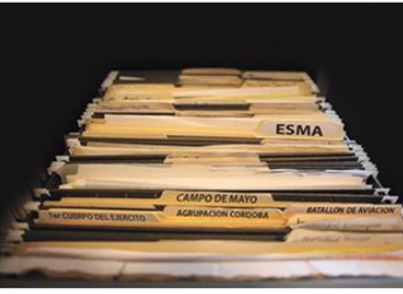

EL ARCHIVO LOS

\section{CONDENA}

Por Alejandra Dand

미요 | Un minucioso trabajo de investigación sobre los documentos archivados por las Fuerzas Armadas durante la dictadura, realizado por la Dirección de Derechos Humanos de Ministerio de Defensa, permitió identificar, entre otros, a cien represores en Mar del Plata y a otros 101 que pasaron por la ESMA

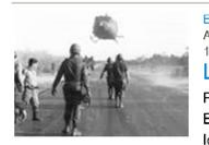

$$
\text { EL PAIS , HOY COMIENZA EL JUICIO POR EL }
$$
Los fusilados de Capilla del Rosario Por el asesinato en Catamarca de los combatientes del ERP que se habian entregado, desce hoyserín juzgedos os militares retirados Carlos Carrizo Salvadores, Mario Nakagama y Jorge Exequiel Acos ta. Está prevista la declaración de 65 testigos.

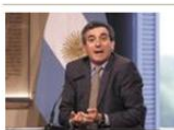

\section{PAIS, SANCIONARONA 130 EMPRESAS DE}

La larga huelga de la larga distancia Los ministros Randazzo y Tomada cuestionaron a empresarios de transporle ya la UTA por la continuidad de la huelga. La CNRT labró 228 actas de infracción a las compañias por incumplimiento de servicios y por cerrar sus boleterias.

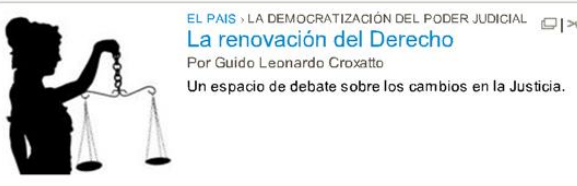

\section{叐 Presidencia de la Nación}

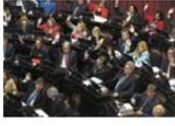

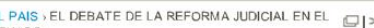
La hora del Consejo

Cámara de Senadores se prepara para convertir en sla semana tres de los proyectos del paquete de la 列

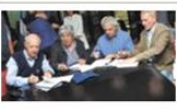
EL PAIS, OPINIÓN
¿Sólo una guerra de vedettes? Por Eduardo Alvert

La foto politica de la ultima semana fue, a no dudarlo, el encuentro de Hugo Moyano, Francisco de Narvaez,

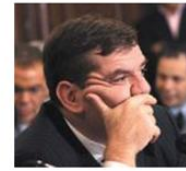

E. PAIS , LA RELACIÓN DE GUILLRMO MONTENEGRO 미٪ ASOCIADOS

a consultora privilegiada del ministro Por Gustavo Velga

Rin

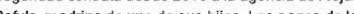

unw.pagina12.com.ar/diario/principal/indexhtml

\section{ULTIMAS NOTICIAS}

Tomada: "Es una clara

presión para que la

actividad vuelva al sistema de subsidios"

El ministro de Trabajo, Carlos un acuerdo hoy entre la UTAY las empresas de ómnibus de larga distancia... [+]

10:34, LA LARGa HUELGa De La LARGA Para la CNRT, el conflicto entre empresarios y UTA es entre empresarios

Luego de aplicar sanciones a 130 empresas de micros, el interventor la Comisión Nacional de Regulación del Transporte (CNRT), Ariel... [+]

12:35, CON "RESPALDO NORMATIVO" Desestimaron una denuncia contra Gils Carbo El juez federal Sebastián Casanello descartó la pres entación hecha con Aejandra Gils Carbó, por supuestas... [+] Comenzó el juicio p La Cámara Oral Federal en lo Penal La Camara Ora Rederal en lo Penal mañan a tres represores por fusilamiento de 14 militantes de Ejército... [+]

11:10, LO QUE DEJO EL CLASICO La Justicia clausuró dos populares de la cancha de Boca

El fiscal porteňo Martin López Zabaleta dispuso la clausura de las tribunas populares en las que los hinchas $d e$ Boca extibieron bandera alusivas... [+]
14:06, LA LARGA HUELGA DE LA LARGA la Procuradora General de la Nación,

10:52 , MEMORIA, VERDAD Y JUSTICI

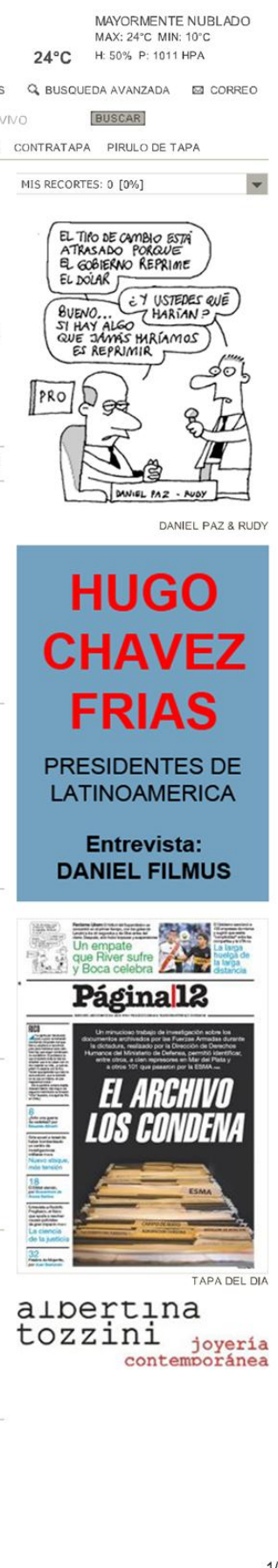

$1 / 4$

Página12.com ha sido el medio que menos cambios ha tenido en el período indagado entre 2001-2010. En general, ha conservado un fácil acceso y sencillo diseño para los lectores-usuarios, con una gran similitud entre su edición impresa y su edición digital. El cambio más relevante que tuvo fue el de agregar los triángulos debajo del isologo que permiten el acceso a las ediciones anteriores sin previo ingreso al archivo. 
Estos rasgos de P12.com construyen la conexión estilística con la crítica tecnológica a las páginas web que no tienen códigos abiertos y de acceso libre como Linux. Esto se suma a la referencia regional que supone el reenvío a un diario brasileño -Carta Maior-, a la posición ecológica, a la defensa de los derechos humanos y de los derechos sociales, políticos y económicos, a la crítica a la obsolescencia programada por el consumismo capitalista, el progresismo político, entre otros. Serán rasgos recurrentes en la presentación y construcción de las noticias de P12 y P12.com que analizaremos y, en particular, alimentarán y formarán parte de la posición laicista y plural que asume el diario frente a lo religioso ${ }^{50}$.

Clarín.com presenta sus informaciones en columnas jerarquizadas por la urgencia e importancia que le otorga a cada noticia y que suele indicar según el espacio asignado y el lugar en ese espacio de acuerdo al orden de lectura: de arriba hacia abajo y de izquierda a derecha presenta los títulos y fotografías destacadas, en similaridad con la edición impresa. Sin embargo, el modo de presentación de las noticias cambia en el período 2001-2010:

\footnotetext{
${ }^{50}$ También en la entrevista a Washington Uranga hablamos de este tema: según el periodista, “... en la redacción predomina el agnosticismo aunque yo soy católico y siempre me han tratado con mucho respeto". El posicionamiento del medio varía de acuerdo a los temas y a las políticas editoriales que lo caracterizan en torno a los Derechos Humanos, la militancia a favor de los derechos de la mujer y el Movimiento de Sacerdotes del Tercer Mundo.
} 


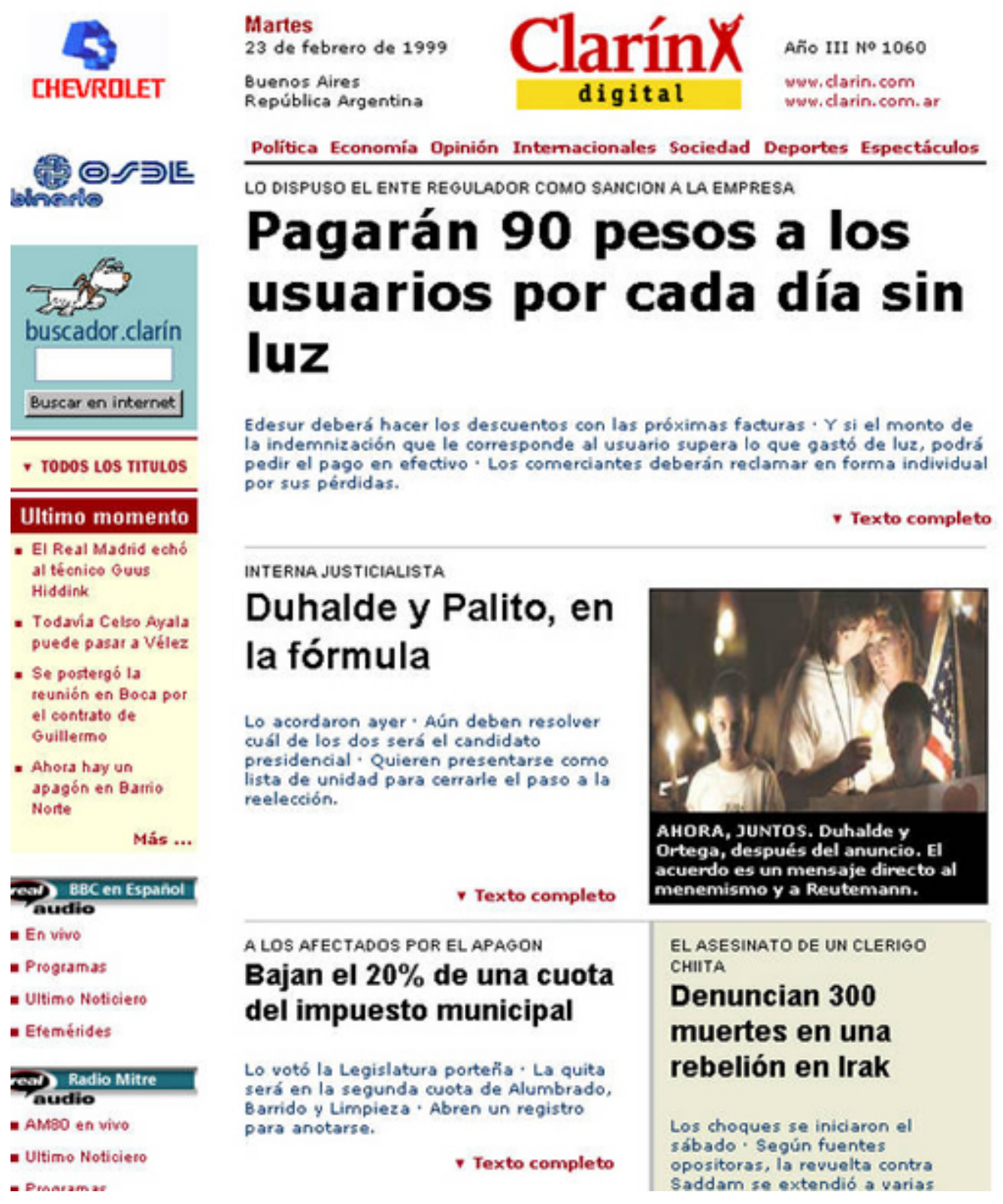

Del "Clarín Digital" de fines de la década de los noventa, muy cercano en diseño y contenido a la edición impresa, al "clarin.com" de comienzos de la década del dos mil, en la poscrisis argentina, hubo muchos cambios: formales, compositivos, en el diseño y el diagrama, pero también en las utilidades multimedia. Por eso hablamos de diseño multimedial, la función y el uso están ligados en el diseño de las interfaces de la plataforma: 


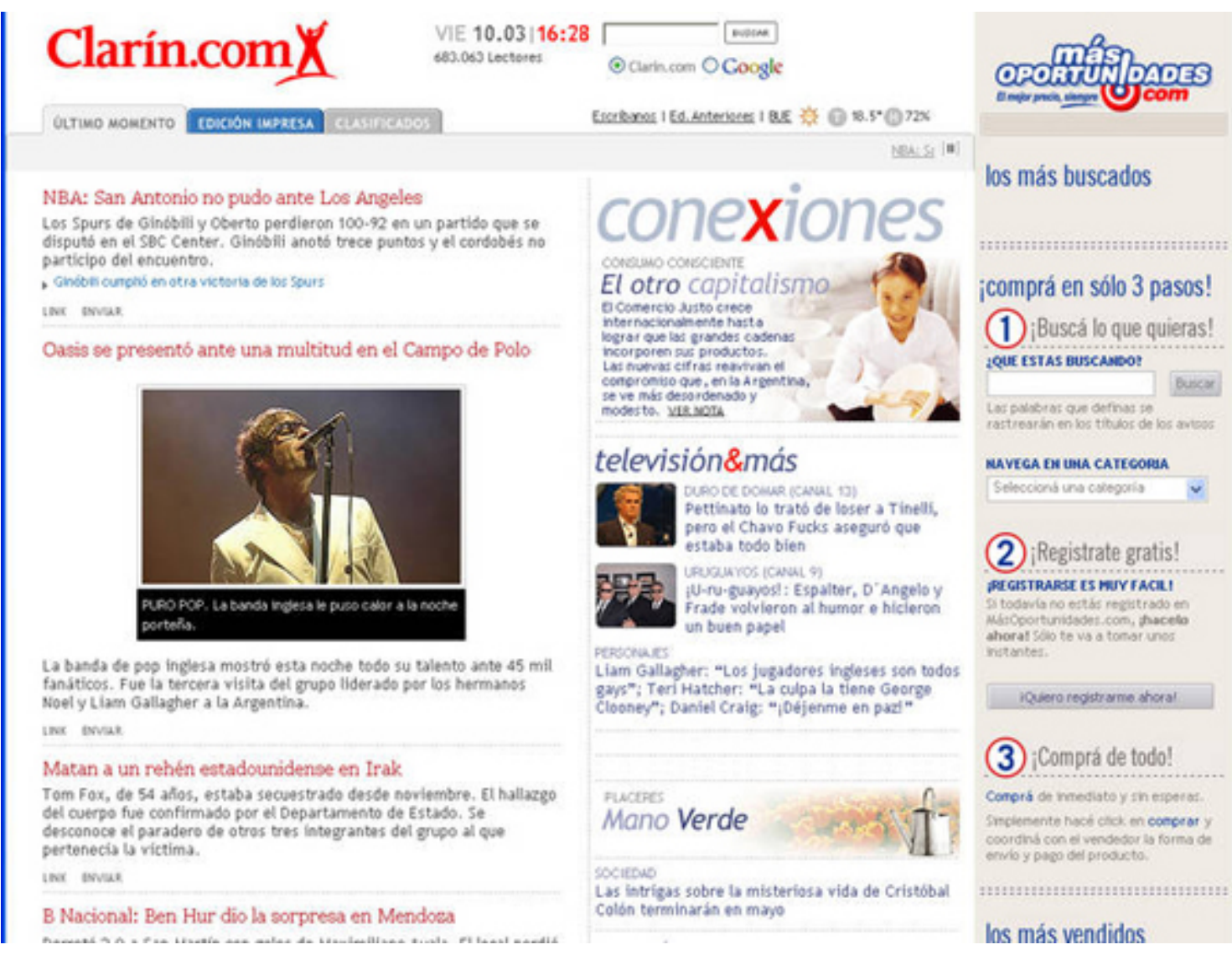

El sitio web continuó sin cambios significativos hasta 2008, aunque agregó cada vez más contenidos y herramientas multimediales: 


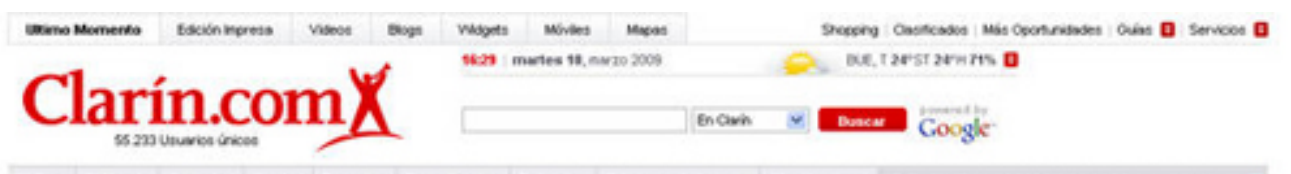

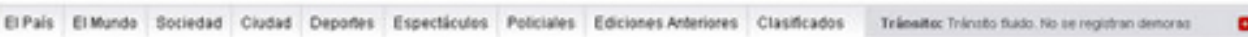
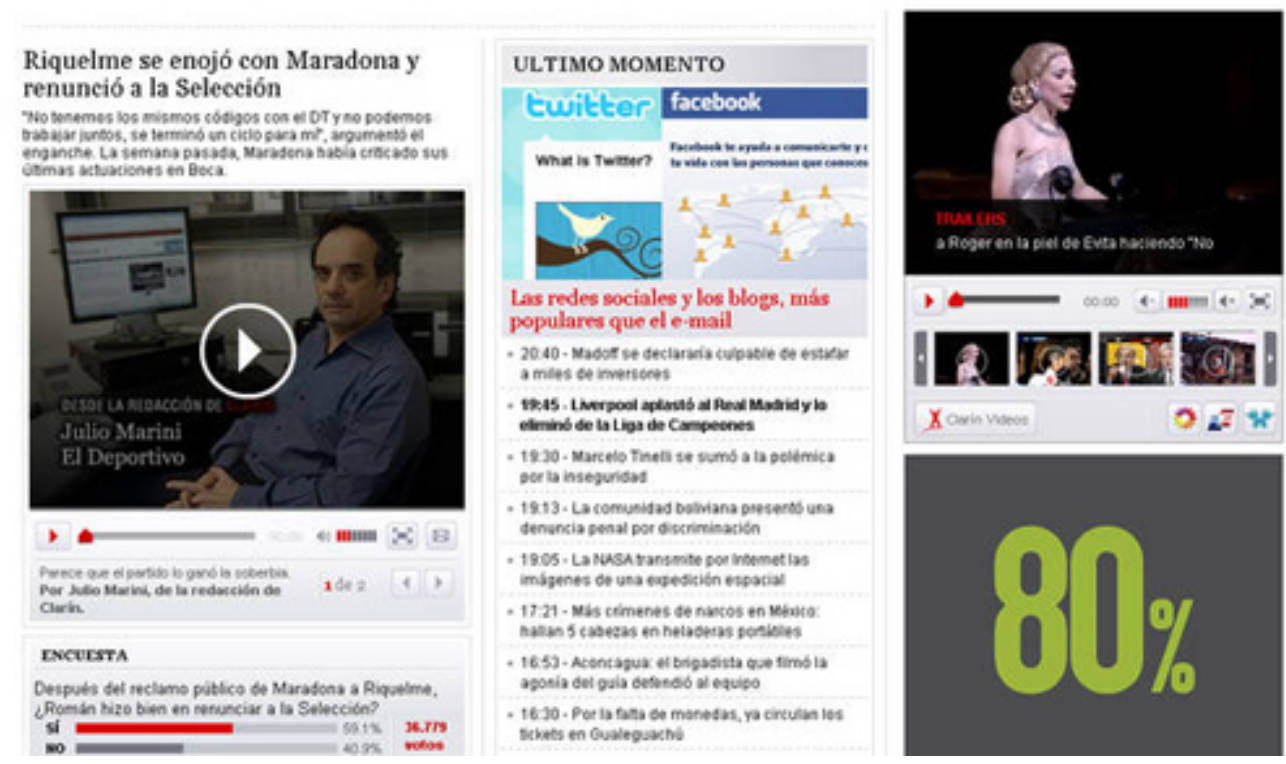

En 2010 introdujeron algunas variaciones en el isologo y en la portada, así como también crearon una sección que se ocupara de los contenidos multimediales bajo el nombre de "Clarínwebtv": 


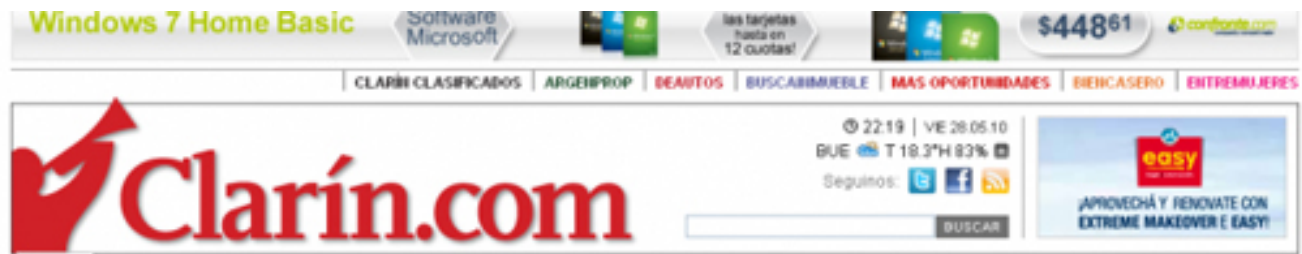

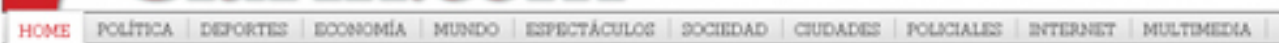

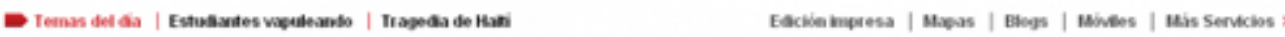

Tras el escándalo, en Santa

Cruz niegan que los fondos se hayan gastado en su totalidad

DIO | $000010000 \mid$ | 1 IIIIIII

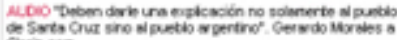

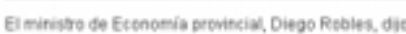

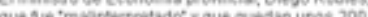
millones de oblares. Aver, en una erbevista rabal hasia munciado que les fondos se pastaren "en s movilusar.

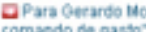
jastioun los fondos extracrdinariod

Cuatro heridos y 11 chicos detenidos durante una rateada convocada por

Facebook en La Plata

Numnas de colegiss nales se enthertarton en sieno corto do la captal bonsewnte Yluego atacaron a is

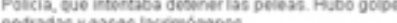

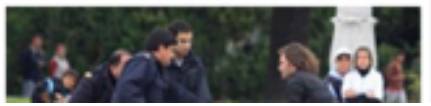

El viaje más esperado

El plartol de la selectión despego esta tarde hacia

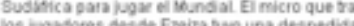
emotin de la gertie

ances |vero

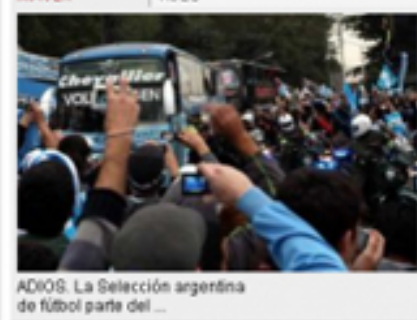

Otro revés judicial para Macri: revocaron su sobreseimiento en el mobiliario urbano

La Cimara del Camen ie suginib al jefte de Ootiems

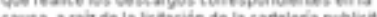

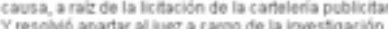

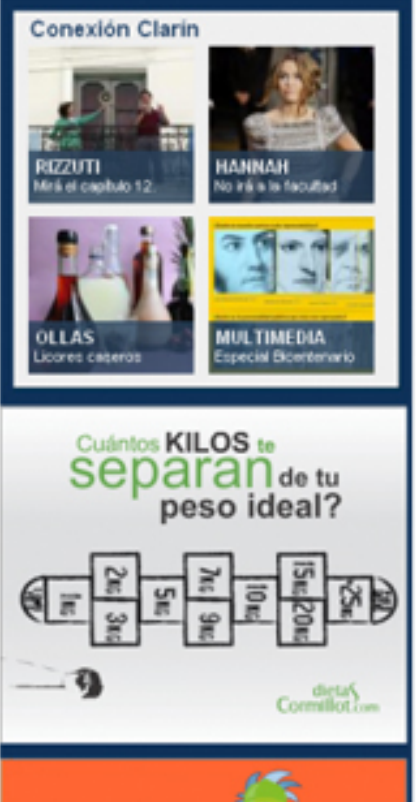

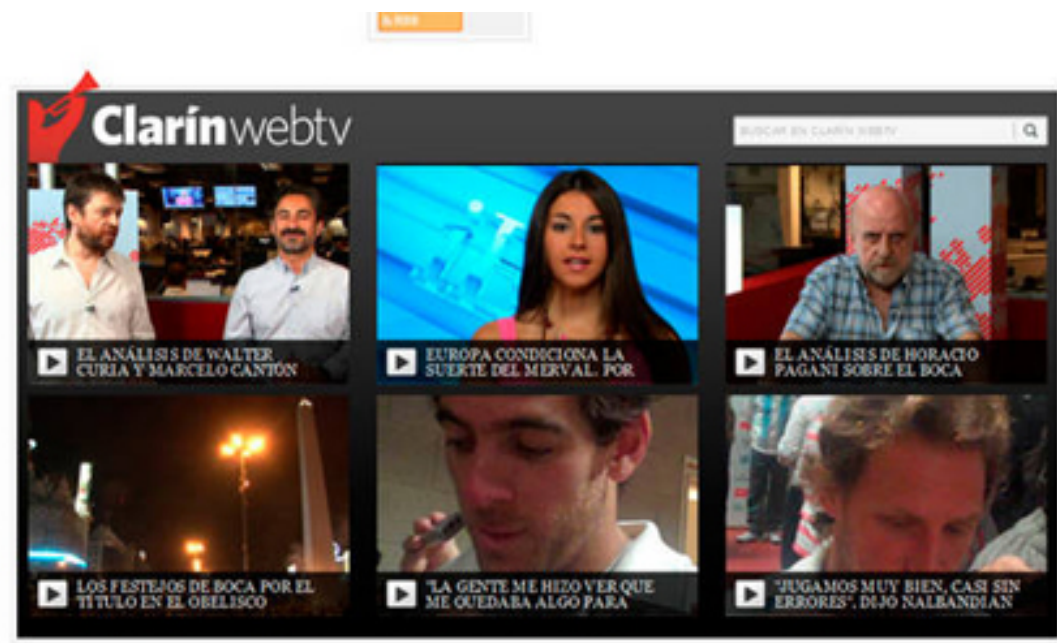
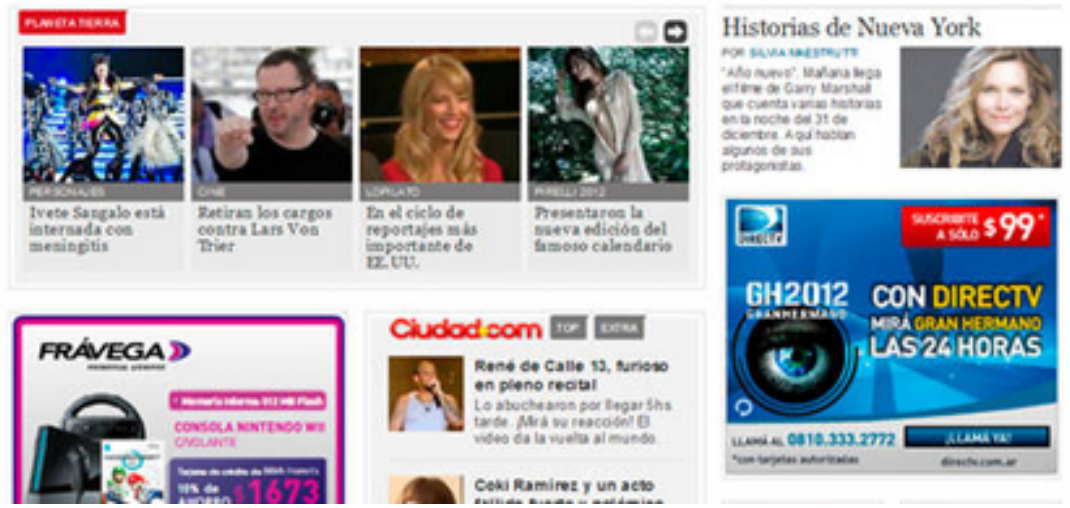
De esta manera las diferencias entre las ediciones digital e impresa son significativas. Si bien continúan rasgos identificatorios entre la edición papel de Clarín y la edición de clarín.com, cuyas informaciones digitales son actualizadas varias veces al día en la edición online ${ }^{51}$.

En cambio, lanacion.com plantea distintos modos de lectura posibles en su sitio web respecto al formato sábana ${ }^{52}$ de su edición impresa, e introduce marcadas innovaciones en el diseño multimedia y en la posibilidad de uso de las herramientas de participación para los lectores-usuarios (Diéguez, 2012, 2015).

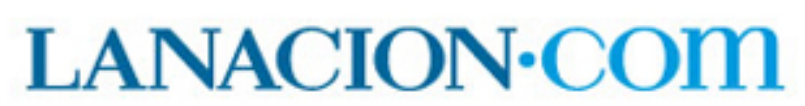

\author{
Centro del lector \\ Ingresar | Registrarse
}

Buscar

Buscador avanzado

| Noticias - Deportiva Entretenimientos Tecnología Opinión Edición impresa Autos * E

Jueves 01.11.2007 Actualizado 18:45 (hace $18 \mathrm{~min})$ | BUE $\quad$ T: 22 $2^{\circ}$ S: $20^{\circ}$ H: $43 \%$ Pronóstico | Tránsito

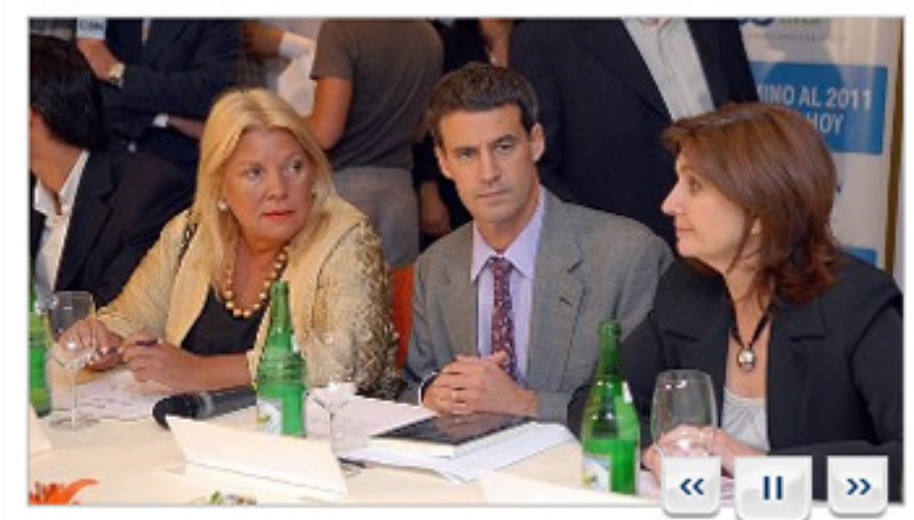

Presentó Carrió su nuevo espacio político

Convocó a todos los que "compartiendo los principios se sumen a un proceso donde nadie sea cooptado", e introdujo a su equipo técnico y las áreas de su fuerza
Recursos públicos

Creció un $32,1 \%$ la recaudación en octubre

18:35 | Ingresaron a las arcas del Estado $\$ 17.650$ millones; superó las previsiones de los analistas; en los últimos 10 meses se acumula un crecimiento del 32,5 por ciento

Informe: Recaudación de octubre

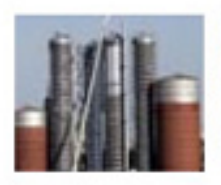

Botnia: sube la tensión por las marchas y contramarchas Por Lucas Colonna > Ver video

\footnotetext{
${ }^{51}$ El aumento cuantitativo en las noticias de la portada digital de los diarios es creciente y las actualizaciones cada vez más frecuentes, de acuerdo a las observaciones sobre diarios digitales que realizamos desde 2005 en los trabajos prácticos de las comisiones en las que me desempeño como docente en la cátedra Comunicación y Cultura I de la Facultad de Periodismo y Comunicación Social de la UNLP.

${ }_{52}$ En 2016 La Nación modificó por primera vez en su historia el formato sábana a uno tabloide, aunque el diseño y diagramación de la edición impresa conservó su similitud en el nuevo tamaño.
} 


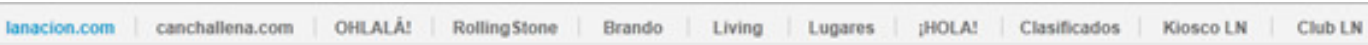

$$
\text { lanacion.com }
$$

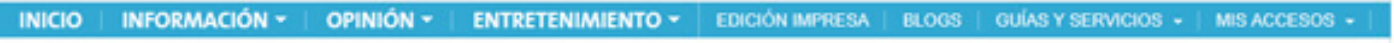
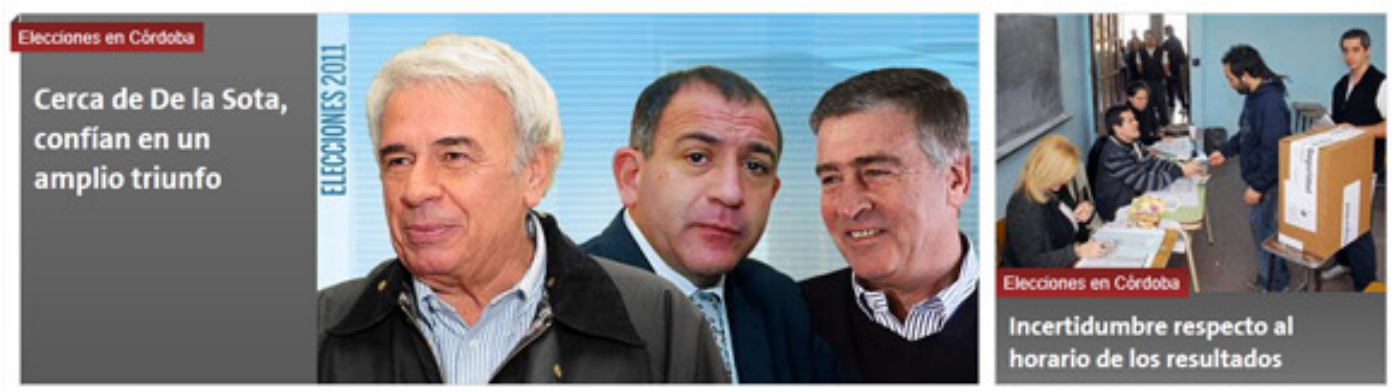

TEMAS DE HOY Elecciones en Córdoba Doble crimen en Salta Crisis económica global Torneo Apertura

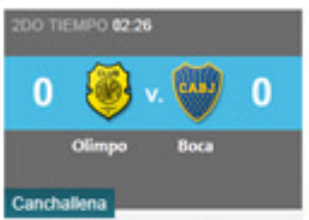

En Bahía, Boca no la pasa bien

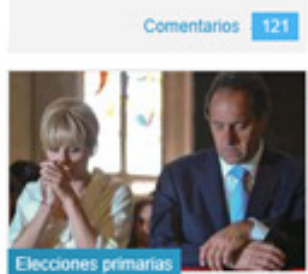

El aviso espiritual de Scioli despierta polémica en Twitter

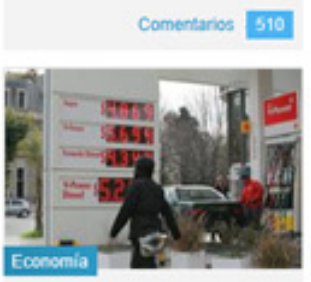

comida en casa, una buena forma de combatir la inflación
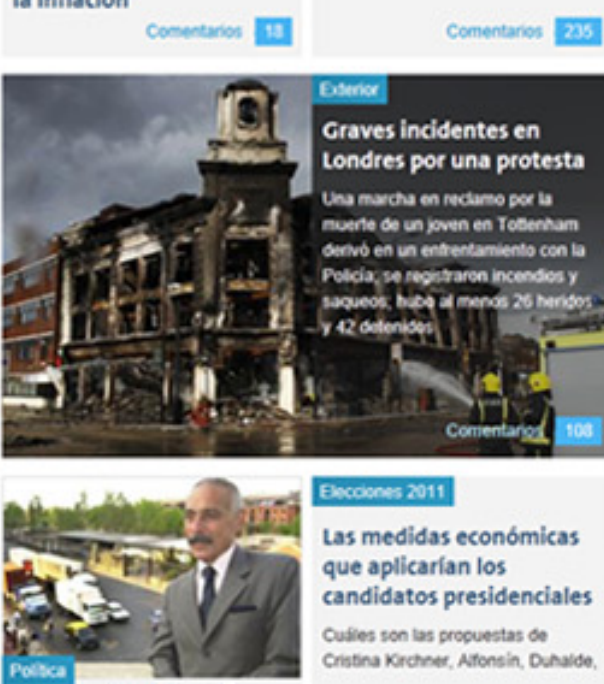

Erocosens 2011

Las medidas económicas que aplicarian los

candidatos presidenciales

Cuiles son las propuestas de

Cristina Kroterer, Afonsin, Danalde.

más de mil alertas de lavado

bebe muerta confesb que

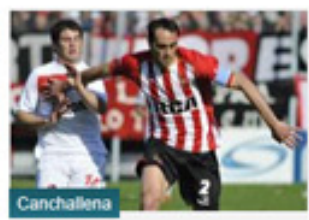

I8 AÑOS ACOMPASANDOO

Estudiantes no pudo, Newell's no quiso

Comentarios 53

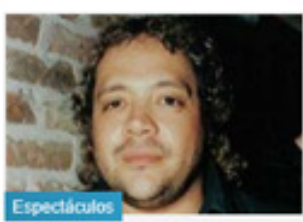

Murió el cantante bailantero Leo Mattioli Comentarios 123

\section{Polisa}

Difunden nuevos e-mails privados de funcionarios del Gobierno

Se trata de correos revelados por el sto LealyMals, segin una investigación de Clarín
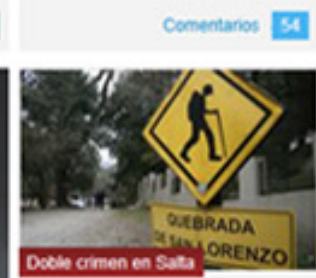

Creen haber resuelto el doble crimen de las francesas

Comentarios 39

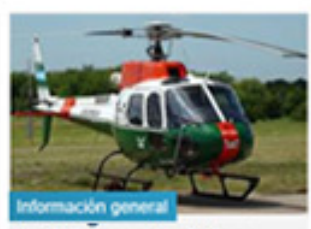

helicóptero derribó una avioneta con drogas
@LNespectaculos

LUGARES

Leés Lugares, ya estuviste un poco ahi.

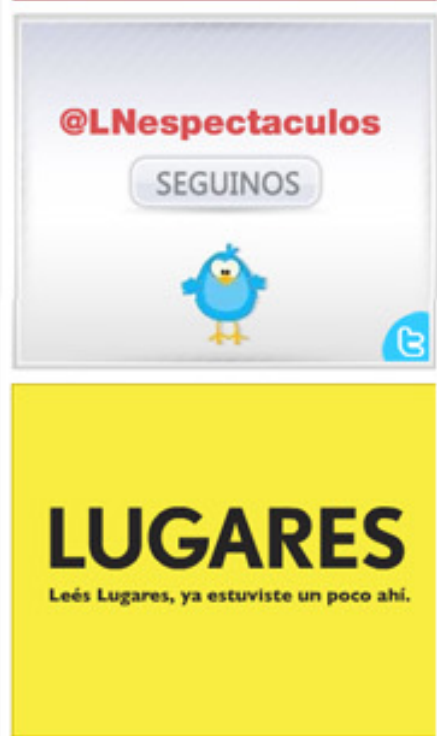

Factura Electrónica

NOTAS MÁS LEÍDAS AHORA Ver lodas

1 Festejos en el buinker de De la Sota tras los comicios en una provincia clave

2 El aviso espirtual oe Sciol despierta poltmica en Tweter

3 Ayacucho: la madre de la bebe muerta contesb que minso

4 Munb el cantante batantero teo Matbol

5 Santiago oet Estero un nescodotero 5 derrob una anoneta con arogas
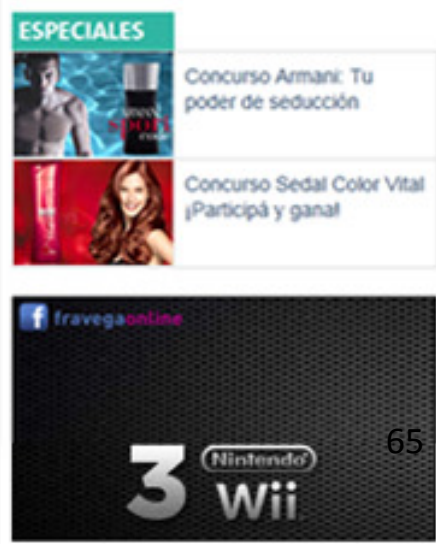
En el tratamiento que los diarios digitales hicieron de los fenómenos de religiosidad, analizados desde el enfoque sociosemiótico propuesto, se visibilizaban sus diferencias por sus estilos socialmente reconocibles. Si bien la sola clasificación estilística no alcanza para describir los funcionamientos mediáticos de un diario, también es cierto que estas asignaciones sociales de sentido ya estaban presentes en las tradiciones, prácticas e historias de cada medio y que han pasado a formar parte de sus condiciones de producción como saberes sociales.

Con los fenómenos de mediatización (Verón, 1997, 2001, 2013) las sociedades contemporáneas construyen sus acontecimientos informativos también de acuerdo al saber social sobre la presencia de los medios en los espacios públicos:

El proceso que nos interesa es el inaugurado por la prensa escrita de masas en el siglo XIX, que se acelera con el advenimiento de la fotografía, del cine, de la radio, de la televisión, y cuyos avatares conciernen hoy a lo que habitualmente se designa como los "nuevos medios". Soportes tecnológicos cada vez más complejos se han vuelto socialmente disponibles y han dado nacimiento a nuevas formas de discursividad.

En un primer momento, ese proceso ha sido pensado a la luz de una concepción representacional, característica de la modernidad y fundada sobre una visión funcional e instrumental de la comunicación: todos esos nuevos soportes que han aparecido a un ritmo cada vez más rápido son, como su nombre lo indica, medios al servicio de un fin: la comunicación. Esta ideología representacional acompaña la localización de lo que llamaría la sociedad industrial mediática, y provee así a esta última de un principio de inteligibilidad que le permite "comprender" aquello que está por llegar. Una sociedad mediática es una sociedad donde los medios se instalan: se considera que estos representan sus mil facetas, constituyen una clase de espejo (más o menos deformante, poco importa) donde la sociedad industrial se refleja y por el cual ella se comunica. (...) Ahora bien, la mediatización de la sociedad industrial mediática hace estallar la frontera entre lo real de la sociedad y sus representaciones. (...) Una sociedad en vías de mediatización es aquella donde el funcionamiento de las instituciones, de las prácticas, de los conflictos, de la cultura, comienza a estructurarse en relación directa con la existencia de los medios. (Verón, 2001b: 13-14)

La visibilidad pública en sus modos diferentes de presentar las noticias sobre religión, en el conjunto de la información de actualidad, se relaciona con transformaciones sociales amplias como las que mencionamos acerca de la mediatización, pero también con el rol institucional público (Casanova, 1994) que las religiones tradicionales 
adquirieron en el último cuarto del siglo XX y los primeros años de este siglo, además de los factores que atañen al cambio tecnológico (Castells, 1998, 2009; Scolari, 2008).

La privatización e individuación de las creencias religiosas y la desregulación en el campo religioso institucional (Hervieu-Léger, 2004) producen una fragmentación y diversificación del creer (Mallimaci: 2007, 2001; Esquivel: 2005). Al estudiar cómo las religiones históricas se vuelven religiones públicas, el teórico de la sociología de la religión José Casanova abre su libro con la siguiente frase:

La religión se $<<$ hizo pública $>>$ en los años ochenta en un sentido doble. Entró en la $<<$ esfera pública $>>$ y ganó, por ello, $<<$ publicidad $>>$. Diversos $<<$ públicos $>>-$ los medios de comunicación, los sociólogos, los profesionales de la política, y el $<<$ público en general $>>$ - comenzaron de repente a prestar atención a la religión. Este inesperado interés público derivaba del hecho de que la religión, abandonando el puesto que tenía asignado en la esfera privada, se había metido en la plaza de la controversia política y moral. (1994: 15).

De este modo, la mediatización de lo religioso se da por su mayor visibilidad pública institucional (Hjarvard, 2016, 2013, 2006) pese a su pérdida de influencia en las prácticas sociales privadas.

En esta historia de la mediatización de las sociedades industriales, algunos jalones o más bien algunos síntomas: el debate Kennedy-Nixon del que tanto se ha hablado, y que marcó el comienzo de la audiovisualización de lo político; el descenso del primer hombre sobre la luna, cuyos primeros pasos fueron programados en función de la cámara de televisión que debía difundirlos a todo el planeta; la estrategia de Juan Pablo II, primer papa mediático, quien comprendió que la religión será mediatizada o no será. (2001b: 15 , el subrayado es nuestro).

Las diferencias en la presentación de las noticias sobre religión, su visibilidad pública en cada medio, suelen ser identificables a partir de sus estilos, definidos como maneras de hacer (Steimberg, 2013, 1993); es decir, por sus formas de construcción y presentación de las noticias, por el vínculo que cada medio propone a los destinatarios, por sus maneras de decir lo dicho (Maingueneau, 1980; Verón, 1998; Metz, 1991) más que por la oposición sincrónica entre sus géneros periodísticos informativos (la entrevista, la crónica, la noticia, el reportaje, el informe, entre otros) y los opinativos (el 
editorial, la columna de opinión, la nota de análisis, la reseña, la crítica, entre otros posibles).

Es destacable que entre las secciones informativas clásicas de los medios como Política, Economía, Internacionales o Policiales, no se haya construido una clasificación que agrupe las 'noticias religiosas' en una sección, aunque no hay impedimento técnico alguno para que suceda ${ }^{53}$.

Existieron periódicos, revistas, suplementos y otro tipo de productos gráficos dedicados a las informaciones religiosas; sin embargo, el género o tipo de discurso religioso involucra a las noticias sobre religión en sus significaciones públicas también de un modo práctico, como nos hacer notar de manera involuntaria el gran antropólogo E.E. Evans-Pritchard:

...contestaría que las religiones primitivas son especies del género religión y que todo aquel que tenga algún interés por la religión debe reconocer que un estudio de las ideas y prácticas religiosas de los pueblos primitivos, que son de una gran variedad, puede ayudarnos a obtener ciertas conclusiones sobre la naturaleza de la religión en general y por tanto también sobre las llamadas grandes religiones o religiones históricas y positivas o religiones de revelación, incluyendo la nuestra. (Evans-Pritchard, 1991 [1965]: 12).

Si bien Evans-Pritchard se refería a los pueblos primitivos como sub-especies del género religión, es notable cómo la afirmación permite pensar las relaciones entre lenguaje y vida, en particular, de esas "correas de transmisión entre la historia de la sociedad y la historia de la lengua" que son los géneros discursivos de acuerdo a como los definía Bajtín (1982):

Los enunciados y sus tipos, es decir, los géneros discursivos, son correas de transmisión entre la historia de la sociedad y la historia de la lengua. Ni un solo fenómeno nuevo (fonético, léxico, de gramática) puede ser incluido en el sistema de la lengua sin pasar la larga y compleja vía de la prueba de elaboración genérica. (Bajtín, 1982: 254).

Si bien aquí no es el lugar para problematizar la noción de género, de todas formas podemos decir que la clasificación científica de Linneo la ha convertido en una

\footnotetext{
${ }^{53}$ Martín Vivaldi [1973: 236] cita un caso español: el del periódico YA, de Madrid, con una sección denominada "Iglesia postconciliar" lo que daría cuenta también del lugar que le asignaba ese medio al Concilio Vaticano II.
} 
herramienta de catalogación del mundo que requiere una revisión del concepto constructivista de género en sus imbricaciones con los modos de nombrar diversas prácticas sociales (Segato, 2003).

Decíamos que en los medios de prensa escrita seleccionados no aparecen géneros ni secciones sobre religión. En cambio, sus temáticas noticiosas suelen ser compartidas y articuladas en las secciones mayores (a grandes rasgos: política, economía, internacionales, sociedad, información general) y menores de la prensa escrita (entre otras: policiales, espectáculos, cultura, deportes). La recurrencia de informaciones sobre fenómenos de religiosidad la encontramos en las secciones de: internacionales, política, sociedad, información general, policiales y en sus posibles organizaciones particulares de cada medio.

\subsubsection{Observaciones descriptivas}

En este apartado presentaremos una aproximación al análisis propuesto por Oscar Steimberg (1993) en Semiótica de los medios masivos y Semióticas (2013).

En particular, trataremos de abordar las noticias sobre religión en tres diarios digitales argentinos: clarín.com, lanacion.com y pagina12.com. A partir de la observación y descripción analítica de sus rasgos retóricos, temáticos y enunciativos analizaremos las inscripciones genéricas y estilísticas como parte de las clasificaciones sociales sobre la prensa escrita que en sus interacciones realizan los medios informativos y la sociedad.

El análisis de los rasgos de las noticias desborda las clasificaciones genéricas y estilísticas por lo que también nos indicará algunas operatorias sociales para realizar la categorización sobre lo empírico que veremos en el próximo apartado.

En última instancia, el análisis enunciativo de las informaciones periodísticas de actualidad religiosa en la sociedad argentina del período 2001-2010 y en los medios señalados es el objetivo principal de nuestra investigación. 


\subsubsection{Descripción previa general}

Los mecanismos de configuración textual que dan cuenta de la dimensión retórica (Steimberg, 1993, 2013) en el análisis de las noticias de los diarios digitales encuentran posibilidades, relativamente novedosas, en los dispositivos tecnológicos (Traversa, 2001) que el entorno informático suma a la configuración formal del diseño, como parte de la disposición del estilo de cada medio, y en tanto marca identificatoria proveniente de los diarios en papel.

Los diarios digitales proponen una entrada de lectura que se convierte en orden y clasificación de ese particular tipo de descripciones del mundo, a los que llamamos acontecimientos informativos o noticias (Charadeau, 2003; Verón, 1987). Al mismo tiempo que los modos de su descripción forman parte de la web como portales del mundo periodístico (Scolari, 2008) o sitios de noticias, también informan sobre los acontecimientos referidos a los mundos públicos compartidos por una sociedad determinada por la historia y por sus prácticas.

Además, los diarios digitales clasifican otros órdenes como guías de recomendaciones de experiencias estéticas y urbanas (Diéguez, 2014) de la vida contemporánea, entre sus descripciones del mundo social, para posibles lectores del texto digitalizado. Lo hacen en sus notas y con informaciones disponibles sobre sitios relacionados, en especial gastronomía, espectáculos, moda, artes, ferias, etc.; en hipervínculos, archivos de noticias u otro tipo de páginas web, blogs y redes sociales a los que se puede acceder desde los espacios del diario digital ${ }^{54}$.

La configuración formal de las noticias en Clarín y CL.COM sobre fenómenos o acontecimientos ligados a la religiosidad no difieren de los mecanismos, operatorias y procedimientos habituales para el resto de sus noticias ${ }^{55}$.

\footnotetext{
${ }^{54}$ Tal como lo entiende Chartier (2008): “A diferencia del orden jerárquico del mundo de los impresos, la continuidad de la textualidad digital en la superficie de pantalla hace, en efecto, menos inmediatamente perceptible la desigual credibilidad de los discursos y así expone a los lectores menos advertidos a las falsificaciones" (2008: 44); y antes “¿Cómo preservar maneras de leer que construyan la significación a partir de la coexistencia de textos en un mismo objeto (un libro, una revista, un periódico) mientras que el nuevo modo de conservación y transmisión de los escritos impone a la lectura una lógica analítica y enciclopédica donde cada texto no tiene otro contexto más que el proveniente de su pertenencia a una misma temática?" (2008: 13-14).

${ }^{55}$ Salvo la excepción del formato particular que adquieren las noticias ligadas con el suplemento y sitio web de la asociación Valores religiosos -www.valoresreligiosos.com.ar- su edición gráfica acompaña al diario Clarín y encuentra remisiones hipertextuales en el diario digital; el suplemento se diferencia del cuerpo principal del diario impreso y trabaja informaciones específicas, muchas veces a modo de
} 
El diseño multimedial en similaridad con la edición gráfica, la habitual compañía de imágenes fotográficas y la capacidad de incorporar videos, hipervínculos a otras páginas y sitios web, estadísticas, rankings, entre otras posibilidades que remedan a los diagramas, gráficos e infografías suelen acompañar a las ediciones impresas ${ }^{56}$.

Respecto del estilo y las valoraciones sociales construidas desde la propuesta textual del medio, CL.COM apela al uso del color rojo en el isologo y a grandes letras desde los títulos de su portada ${ }^{57}$. El rojo, entre sus significaciones, actúa en remisión y permite identificar a la edición digital con la edición impresa pero también reenvía en sus condiciones de producción (Verón, 1987) a otros diarios como Crónica, Crítica y La Razón, con los cuales Clarín tuvo distintas relaciones, desde textuales hasta empresariales en el último caso ${ }^{58}$ (Sivak, 2015; De Diego, 2014).

El color rojo asociado en la portada impresa a la frase "Un toque de atención para la solución argentina de los problemas argentinos” según su lema y, por supuesto, la remisión histórica a la Marcha de San Lorenzo ${ }^{59}$, vincula la emergencia en hacer pública la información para resolver esos problemas. A su vez rememora la sirena de

informes especiales cuyas temáticas pueden estar ligadas o no con la información de actualidad; suele tratar: el diálogo interconfesional, las campañas de beneficencia, las celebraciones de diversas religiones, entre otros. Además, el sitio se autopresenta como una asociación sin fines de lucro ligada a autoridades religiosas -como el sacerdote Guillermo Marcó, ex vocero de Bergoglio- y cuyo editor periodístico es Sergio Rubin, periodista especializado en informaciones sobre religión del diario Clarín y CL.COM.

${ }^{56}$ Es interesante el hecho de que, en los últimos años, las ediciones gráficas del diario reenvían de manera explícita a la edición web para ampliar información sobre un tema noticioso, lo cual indica no sólo la posibilidad de actualización informativa del diario digital sino su peculiar capacidad productiva en el volumen de noticias y su funcionamiento como archivo, en combinación con las posibilidades que ofrece Google y los buscadores digitales. Scolari $(2004,2008)$ también da cuenta de la importancia que adquieren las actualizaciones en el diario digital y cómo cambia la lógica del diario impreso. Volveremos sobre esto.

${ }^{57}$ El impacto de la portada también cambia de significación entre otras diferencias del diario digital y el diario impreso. Entre otras razones, porque la edición digital permite corregir y ampliar informaciones publicadas en papel y porque ya no hay una hora de cierre de la edición en el diario digital que marque el paso de una jornada informativa y su continuidad en la siguiente, sino que con el diario digital hay una actualización relativa de las noticias que acentúa dinámicas del llamado sistema de medios, heredado del broadcasting de los medios tradicionales donde antes la prensa gráfica, la radio y la televisión se retroalimentaban y retrabajaban sus noticias (Scolari, 2008).

${ }^{58}$ De Crítica y Crónica, Clarín ha buscado distintas maneras de acercarse a su público supuestamente "popular": en la imitación de algunos rasgos de estilo como la claridad informativa, la enunciación breve de los títulos, las comparaciones metafóricas, entre otras. Clarín "heredó" los avisos clasificados de $L a$ Prensa cuando este diario fue expropiado en 1951 por el segundo gobierno peronista. Respecto a $L a$ Razón, Clarín fue su socio en Papel Prensa en la década de 1970 y compró el diario el 27 de diciembre de 2000; lo hizo de distribución gratuita en papel, al ser repartido en los medios de transporte públicos en la ciudad de Buenos Aires. Entre múltiples trabajos que hacen referencia a la historia del periodismo argentino citamos: Ulanovsky, 1997; Laiño, 1986; Ramos, 1993; Luna, 1986; Botana, 1977; Tálice, 1977).

${ }^{59}$ Es significativa la estrofa de la Marcha: "Son las huestes que prepara/ San Martín para luchar en San Lorenzo;/ el clarín estridente sonó/ y la voz del gran jefe/ a la carga ordenó”. De allí, tal vez, su nacionalismo inicial, proclamado en los primeros años de Clarín. 
alarma que había hecho instalar Natalio Botana en el frente del suntuoso edificio del diario Crítica, para alertar a la población de los acontecimientos informativos que consideraba relevantes.

Con este haz de remisiones y significaciones pareciera que no hace falta explicar por qué Clarín tiene ese nombre de origen ${ }^{60}$. Sin embargo, una revista llamada Clarinada fue uno de sus antecedentes en el mundo de la prensa gráfica:

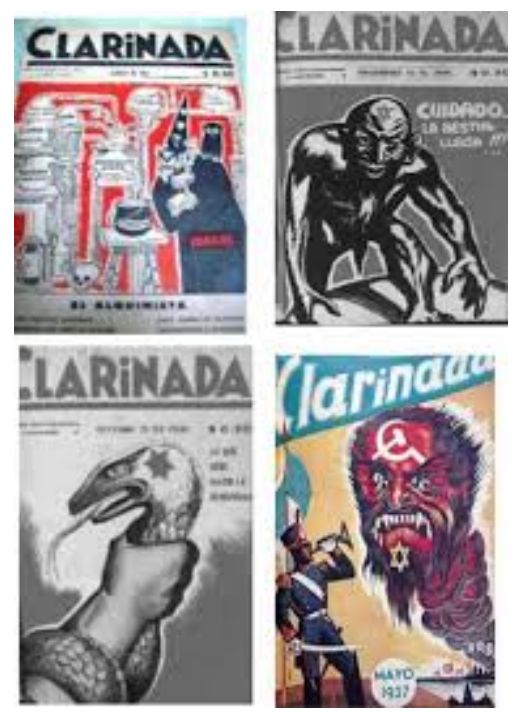

Publicada entre 1937 y 1945 esta revista se declaraba anticomunista, antisemita y fascista. Dirigida por Carlos Sylveira, Clarinada representaba al nacionalismo católico argentino de ese entonces. El nombre de la revista proviene del vocabulario militar, una clarinada es un "toque del clarín" y por desplazamiento de sentido remite a "... un dicho intempestivo o desafortunado" (según diccionario de la Real Academia Española, http://dle.rae.es/srv/fetch?id=9PV6So2).

\footnotetext{
60 “El diario salió a la calle por primera vez el 28 de agosto de 1945. Sivak pone en cuestión el "mito fundacional" construido alrededor de las fuentes de financiamiento. Según la versión difundida por Noble, los fondos provinieron de la venta de su estancia. Sin embargo, el autor comprueba dos datos que lo desmienten: la transacción fue cerrada después del lanzamiento de Clarín y la suma necesaria para montar un periódico de esas características era mucho mayor a la declarada públicamente. Ciertamente, Noble recibió dinero de un grupo de empresarios y gran parte del papel le fue provista por el periódico nacionalista Cabildo.”, reseña escrita por Nadia Koziner de la obra de Sivak sobre Clarín en: Revista Prismas, disponible en: http://www.scielo.org.ar/scielo.php?script=sci_arttext\&pid=S1852$\underline{04992014000100028}$
} 
Según el periodista e investigador Martín Sivak, en los comienzos del diario Clarín: "El caso de Noble, eran bobinas de un diario financiado por la embajada alemana y por un grupo de empresarios. $" 61$.

Sin embargo, actualmente y desde sus comienzos, la identificación de Clarín con el rojo funciona también para diferenciarse de otros diarios, y posteriormente del azul ${ }^{62}$. El estilo supuestamente europeísta, conservador e intelectual de La Nación, actúa en su identificación con el periodismo político liberal desde la fundación del diario por Bartolomé Mitre como representante de la facción liberal del último tercio del siglo $\mathrm{XIX}^{63}$.

Pese a la voluntad laica de su fundador que quería un periódico alejado de las presiones de la Iglesia Católica, La Nación estableció vínculos y alianzas con el Episcopado católico argentino desde comienzos del siglo XX: entre sus páginas escriben y escribieron líderes religiosos católicos, publican sus fallecimientos, conmemoraciones religiosas, aniversarios e incluso, hasta el momento actual, la liturgia del santoral católico es publicada cada día ${ }^{64}$.

A diferencia de esta posición y de sus relaciones en los comienzos con el nacionalismo católico, Clarín ha presentado la imagen de un distanciamiento en la construcción de las informaciones sobre religión (la supuesta "neutralidad" de la que hablamos en la postulación de un "periodismo independiente", que paradójicamente ha dependido en distintas épocas de una relación subsidiaria de beneficios y negocios con

\footnotetext{
${ }^{61}$ Entrevista a Martín Sivak de Ideas de Izquierda, disponible en: http:/laizquierdadiario.com/MartinSivak-La-debilidad-del-kirchnerismo-fue-entender-a-Clarin-solo-a-partir-de-1976

${ }^{62}$ En el Diccionario de los colores de Michel Pastoureau (2009) se puede leer que el azul es el color preferido por Occidente en la actualidad y que, en particular, lo fue en las cortes monárquicas de Europa al menos desde el siglo XII mientras que en Oriente las preferencias cambian. Aunque, por un lado, La Nación incorporó tardíamente el color en su diseño y, por otro, las remisiones de los signos no tienen un destino único en la significación pero, como señala el autor, también en el campo de los colores interviene lo cultural y ese diccionario es interesante para dar cuenta de sus usos y costumbres histórico-sociales.

${ }^{63}$ La Nación fue fundado el 4 de enero de 1870; según Sidicaro (1993: 7) desde 1909 se propuso ser un periodismo sin partido, que educara a las elites argentinas. Además Sidicaro (1993, Cap. 8 "El gobierno peronista: de la crítica al apoyo") afirma que el diario La Nación fue favorable al segundo gobierno de Perón, ya sea por estar de acuerdo con cambios en la política del gobierno peronista o como estrategia de supervivencia frente al cierre de La Prensa, pero nada dice del nacimiento de Clarín en 1945 en su análisis.

${ }^{64}$ La edición impresa de La Nación publica el santoral católico en el que se indica la lectura bíblica de ese día y se hace una breve reseña de la historia del santo; en la edición online, si bien el santoral no suele aparecer en la portada web, es posible reencontrarlo en las secciones o en el archivo digital del diario, bajo el título de la subsección "Culto católico". Sólo hay referencias a las religiones tradicionales (judaísmo, islamismo, cristianismo) en la subsección "Actualidad religiosa", en fechas celebratorias (Janucá, Ramadán, por ejemplo) o en otras ocasiones especiales.
} 
el Estado) pese a que, en las estrategias coyunturales, la posición política del medio muchas veces favorece y hace visible las posiciones eclesiásticas católicas.

Sin embargo, Clarín se afianzó históricamente en su vínculo con el gobierno asumido por Arturo Frondizi, llamado desarrollista ${ }^{65}$, si bien sobre la base de alianzas y estrategias políticas que proscribieron al peronismo en esas elecciones -y pese a que el crecimiento del diario de Roberto Noble fue posibilitado por el aumento de los avisos clasificados que Clarín aprovechaba y descontaba de la conflictiva situación del diario La Prensa, desde 1946 hasta 1951, cuando el diario fue expropiado. Los principios de la doctrina desarrollista se visibilizaron en el entramado político de la posición editorial de Clarín hasta sus rémoras en la actualidad (Sivak, 2015; Mochofsky, 2011).

Lejos de una posición laicista -como es la de Página/12 y P12.COM- Clarín y CL.COM reconocen a la Iglesia Católica como un actor político fundamental de la vida pública argentina: lo hacen al considerar la importancia que sus noticias le adjudican a la relación política de cada gobierno con las jerarquías eclesiásticas de la Conferencia Episcopal Argentina y del Vaticano, en la atención informativa sobre las reuniones y declaraciones de cardenales y obispos.

Como decíamos, Clarín y clarin.com proponen una distancia supuesta -que presentan como "neutralidad" política ${ }^{66}$ - respecto de las tensiones y fuerzas vivas de la sociedad, de sus disputas en el espacio público. Aunque en el centimetraje, los títulos y el enfoque construido de las noticias puede visualizarse la imagen en posición, el punto

\footnotetext{
${ }^{65}$ Clarín se proclamó como desarrollista aunque su crecimiento resultó del cierre de otros diarios, en particular de la intervención y expropiación de La Prensa, durante el gobierno de Perón, y en las dictaduras cívico-militares donde, en la última, consiguió apropiarse de la mayoría accionaria de la empresa de producción de celulosa Papel Prensa (Sivak, 2015; Mochofsky, 2011; Cecchini y Mancinelli, 2010; Ramos, 1993). Además de la bibliografía citada, existe un informe elaborado por la Secretaría de Comercio en 2010 y publicado bajo el título "Papel Prensa. La verdad".

${ }^{66}$ Coincidimos en varios puntos con la caracterización que hace Beatriz Sznaider sobre las ediciones impresas de La Nación y Clarín, en el caso del Bicentenario: "Sobre ese horizonte argumentativo, el tradicional diario La Nación -sostenido en su lema fundacional por el que asume un lugar rector frente a sus lectores- publicó su principal aviso conmemorativo del Bicentenario (...). Pero el nombre del diario en la tipografía tradicional que lo identifica-, queda jerarquizado tanto por el tamaño de la fuente como por uso del color. Entre el eslogan y la firma, el espacio en blanco impone una profundidad que invita a la reflexión. Pero el orden constructivo define casi un sentido unívoco: el motivo a celebrar es la existencia del diario. Su historia es la de la Patria; el Bicentenario, sólo su marco. El diario Clarín, históricamente orientado a sectores medios urbanos y caracterizado por una enunciación borrada, transparente, que tiende a disolver el lugar de la institución como emisor responsable, publicó como aviso principal del Bicentenario un acróstico sobre la palabra Argentina que contenía el nombre de todos los integrantes de la Primera Junta del Gobierno de 1810. El registro llano, horizontal, impone un espacio de alianza y juego entre enunciador y enunciatario, sin conflicto ni tensión, propio del estilo del diario", (el subrayado es nuestro; Sznaider, 2012).
} 
de vista distanciado: es un conjunto de efectos de sentido construidos para transparentar su acción mediática, por oposición a una enunciación que buscaría el efecto de opacar, de mostrar sus condiciones productivas (Recanati, 1981; Marin, [1977] 2015; Metz, 1979, 1991).

La construcción de representaciones sobre la participación y auto-representación del diario -perteneciente al Grupo Clarín- como actor político y como institución mediática corporativa ha formado parte, históricamente, en la configuración social de una supuesta clase media argentina, a veces, demasiado amplia para los parámetros periodísticos y aún sociológicos ${ }^{67}$ que involucrarían a la clase media empobrecida, a la clase media-media y media-alta, según los años ${ }^{68}$.

En resumen, el estilo periodístico de Clarín y CL.COM privilegia la sencillez, la rapidez de lectura y la "claridad" informativa incluso al costo de sacrificar la complejidad textual de los puntos de vista interpretativos -como puede suceder en La Nación y LN.COM- o, de las ironías y sátiras, entre otros juegos de lenguaje que suele proponer Página/12 y P12.COM. La “amplitud” y la supuesta masividad del lectorado al que Clarín y CL.COM pretenden dirigirse aparenta una distancia "objetiva" en las representaciones de las distintas posiciones sociales.

Este estilo realiza sus pasajes a la edición digital del diario que se actualiza, amplía y diversifica en clarin.com y, a veces, pareciera perder un poco la enunciación distanciada en las notas de color, en los suplementos, en las notas de secciones y temáticas "secundarias" a la jerarquización principal de la agenda del diario, es decir, en los márgenes de la información principal.

\subsubsection{El tratamiento periodístico de "la Iglesia y los demás cultos"}

\footnotetext{
67 Es frecuente encontrar en los diarios, sobre todo en las encuestas publicadas, las clasificaciones descriptivas pero también valorativas de: clases media-baja, media-media y media-alta.

${ }^{68}$ A este efecto enunciativo de supuesta 'neutralidad' pueden asociarse aspectos posibles del imaginario social argentino y, por otra parte, un contraejemplo fue el titular en tapa de Clarín "La crisis causó dos nuevas muertes" (27/06/2002, http://edant.clarin.com/diario/2002/06/27/portada.htm), cuando las autoridades del diario tenían fotografías que probaban la participación policial en esas muertes. No sólo no las hicieron públicas si no que distorsionaron la descripción y narración de los acontecimientos al ocultar la información, favorecieron y protegieron al gobierno de Eduardo Duhalde, electo por una asamblea y no por el voto popular, después de la crisis de diciembre de 2001.
} 
Respecto a las temáticas noticiosas relacionadas con el tratamiento informativo de las religiones verificamos una presencia cuantitativa de noticias sobre la Iglesia Católica, en particular, sobre la relación del Episcopado católico argentino con el gobierno y el Estado.

En Clarin y CL.COM, las informaciones relativas a las tensiones políticas que desde 2003 -poco después de la asunción presidencial de Néstor Kirchner el 25 de mayo- el periódico comienza a señalar en títulos y bajadas noticiosas, serán una constante en nuestro período de estudio (2001-2010) y continuarán durante el gobierno de Cristina Fernández de Kirchner ${ }^{69}$.

Esta presencia cuantitativa de noticias que tratan o refieren al culto católico, lógicamente, también se encuentra en LN.COM y en menor medida en P12.COM aunque con diferentes acentuaciones temáticas: LN.COM privilegia las informaciones internacionales entre las que aparecen gran cantidad de noticias sobre el Vaticano, los cardenales, el Papa.

En relación con el ámbito local, en LN.COM muchas noticias refieren a las temáticas polémicas y a los debates sobre educación sexual, aborto, discusiones del ámbito político legislativo; en las posiciones y opiniones de los principales referentes de la Iglesia Católica y, en menor medida, algunos representantes de las religiones históricas como el judaísmo, el islamismo y el protestantismo.

P12.COM en cambio privilegia las temáticas referidas a los derechos sexuales y reproductivos, las temáticas de la identidad de género en las que tiene una posición de militancia activa así como en la despenalización del aborto. Estas problemáticas forman parte de su línea editorial y de su estilo periodístico habitualmente calificado de "progresista".

En cuanto a los líderes religiosos que son visibilizados en mayor medida por CL.COM, podemos enumerar en primer lugar a los líderes católicos. En especial la figura del presidente de la Conferencia Episcopal Argentina que en nuestro período de

\footnotetext{
69 "Tensiones" o "gestos" que muchas veces son modalidades en la construcción de informaciones políticas propias de la empresa mediática, otras veces las del diario e incluso las de los periodistas, y otras, tensiones que involucran sectores corporativos: las disputas con el campo en 2008, el reclamo por falta de diálogo y la declaración por la pobreza de Benedicto XVI (http://edant.clarin.com/diario/2009/08/07/elpais/p-01973675.htm); las tensiones por la ley de educación sexual entre 2004 y 2006, las del matrimonio igualitario en 2010, entre otras.
} 
estudio, 2001-2010, fueron Estanislao Karlic y Jorge Bergoglio -antes de ser electo Papa en 2013. También fue habitual la mención de los cardenales argentinos -Leonardo Sandri, Jorge Bergoglio- y los obispos -Jorge Casaretto, Jorge Bergoglio, Héctor Aguer- como representantes de los sectores progresista, moderado y conservador, respectivamente y de acuerdo a los tres medios.

Los casos que marcaron hitos problemáticos en las relaciones del gobierno con la Iglesia Católica fueron los del obispo castrense Antonio Baseotto por sus declaraciones polémicas contra el ministro de salud Ginés Gonzalez García, del obispo Juan Carlos Maccarone, del cura Julio César Grassi por pedofilia o del Padre José "Pepe" Di Paola y el Padre Lorenzo "Toto" de Vedia, por la violencia y la droga en las villas miseria.

En el ámbito de las noticias internacionales destacan las referencias textuales a la figura del Papa y, a nivel regional, a algunos líderes del Consejo Episcopal Latinoamericano (CELAM) o de movimientos internos a la Iglesia Católica como el Opus Dei, Jesuitas, Sacerdotes para el Tercer Mundo, entre otros. La remisión a líderes latinoamericanos, que no sean religiosos argentinos, suele ser escasa en los tres medios.

Los líderes religiosos de otros cultos son visibilizados a partir de informaciones sobre sus participaciones en la sociedad, por sus incursiones en política (los casos del rabino Bergman o de la diputada evangélica Cynthia Hotton) o por las alianzas interconfesionales a partir de ciertos debates legislativos; por ejemplo, las disputas por el matrimonio igualitario en 2010 pero también la alianza de los principales cultos en los debates por la ley de educación sexual, desde 2004 hasta 2006.

Las informaciones sobre judaísmo e islamismo suelen ser tratadas por los medios como religiones tradicionales -junto con las iglesias protestantes de larga trayectoria en el país- que se configuraron en la Argentina a partir de los movimientos migratorios de finales del siglo XIX y principios del XX. Así, los medios dan cuenta de las celebraciones, procesiones y acontecimientos de esas religiones históricas -que suelen ser las religiones consideradas universales (Weber, 1998).

En cambio y paradójicamente, se le otorga a la Iglesia Católica nacional una antigüedad anterior a la de los "criollos": los nacidos en la Argentina antes de finales del siglo XVIII (Mallimaci, 2015, 1993; Esquivel, 2008). En el argumento de la doxa 
mediática esa "preexistencia" no tiene solución de continuidad entre la etapa colonial, en que la Iglesia Católica forma parte de la evangelización española, y la etapa revolucionaria con el nacimiento de la República Argentina.

La Iglesia Católica preexistiría a la nación pero también formaría parte de la época colonial dominada por los españoles; allí, habría una contradicción paradójica con el pasado de la Iglesia Católica, su participación en la conquista española de América. El apoyo de la francmasonería a la mayoría de las independencias americanas da cuenta de ese breve período "anticlerical" durante el siglo XIX.

Las primeras décadas del siglo XX alientan la construcción del retorno de lo que Loris Zanatta llamó ‘el mito de la nación católica’:

El militarismo católico, obviamente, no fue en absoluto homogéneo. Existían en efecto, como es natural, diversas corrientes y sensibilidades en el catolicismo. Estas, sin embargo, comenzaron a articularse en torno al ideal de restauración cristiana y a la correspondiente aversión hacia los principios liberales y socialistas, lo cual las condujo al "redescubrimiento" del Ejército como potencial aliado del revanchismo antiliberal. Tal proceso implicó a su vez la revisión del concepto de nación elaborado por el liberalismo. En esta perspectiva, el pensamiento de los padres del catolicismo argentino fue exacerbado hasta adherir a una tradición que identificaba nación y catolicidad. Fue por lo tanto en la confesión religiosa donde las diversas corrientes católicas identificaron el elemento fundante y el principio inmutable de la identidad nacional.

La cultura católica inauguró entonces la batalla por la "catolización de la historia nacional". De este modo fundó nuevamente el mito del Ejército como custodia de la catolicidad y negó que el liberalismo hubiera penetrado en él alguna vez. (Zanatta, 1996: 35-36, el subrayado es nuestro).

Las relaciones entre religión y política tuvieron distintas etapas en los diferentes gobiernos (Mallimaci, 1988, 1993; Soneira, 1989; Esquivel, 2004, 2008): el Concilio Vaticano II y el crecimiento del llamado Movimiento de Sacerdotes del Tercer Mundo, la Teología de la Liberación en las décadas de 1950-60, el rol de la Iglesia Católica argentina en la última dictadura cívico-militar (Verbitsky, 2007; Dri, 1997; Mignone, 1986; Martín, 1992; Cattoggio, 2015; Franco, 2012).

En cuanto a las noticias sobre islamismo, se puede resaltar su visibilidad durante las dos presidencias de Menem (1989-1999) y en la campaña política de 2003. No sólo por la ascendencia árabe del ex presidente y porque con él se inició la construcción de la 
mezquita de Palermo, proclamada de manera mediática y en ese momento como la más grande de América Latina, sino también por la vinculación que los medios de comunicación establecían con los atentados a la Embajada de Israel y la AMIA.

El seguimiento y resurgimiento de la temática a partir de los atentados a las Torres Gemelas, el 11/9/2001 en New York, también alimentó de noticias a los diarios impresos y digitales que muchas veces insistieron en diversos aspectos de la temática. Desde las posibles pistas y conexiones del atentado a la AMIA en la Argentina con el de Estados Unidos, hasta las sospechas diplomáticas de este último país sobre supuestas actividades terroristas en la zona de la Triple Frontera entre Argentina, Paraguay y Brasil (Giménez Beliveau, 2006).

Respecto a los cultos evangélicos ha sido notorio el seguimiento por los medios del proclamado crecimiento de fieles y el tratamiento noticioso de los grupos evangélicos. En algunos casos, los tratamientos mediáticos se aproximaron a la caracterización de sectas y a la estigmatización social, al ubicar sus informaciones en la sección de noticias policiales de modo semejante a lo que sucede con los cultos afroamericanos, entre otros ${ }^{70}$.

Los medios también han tratado con énfasis los megafestivales de algunos sectores evangélicos como la organización del Festival Buenos Aires 2003 que presentó al pastor argentino radicado en Estados Unidos, Luis Palau. Según el título del diario CL.COM, Palau convocó a cincuenta mil personas en Palermo y según el cuerpo de la nota periodística esa presentación no habría sido la primera:

Palau viene presentándose personalmente en la Argentina desde 1976. Autor de 44 libros sobre religión, predicó ya en 69 países ante unos 14 millones de personas, con un mensaje que los más críticos consideran "liviano". (http://edant.clarin.com/diario/2003/02/01/s-511055.htm).

En 2008 Palau realizó el festival "Sí a la vida" en la avenida 9 de julio y convocó la atención pública, junto con la primera diputada que se proclamó representante

\footnotetext{
${ }^{70}$ Desde el punto de vista periodístico: Silleta (1986) difundió y acompañó las denuncias con la creación de un movimiento antisectas; desde el punto de vista antropológico, Frigerio (1993) analiza ese tratamiento informativo como estigmatización social respecto al tratamiento de las religiones tradicionales. Soneira (2005) reubicó la problemática, a nuestro modo de ver correctamente, con el título de Sociología de los Nuevos Movimientos Religiosos en Argentina.
} 
legislativa de esos sectores evangélicos: Cinthya Hotton (Algranti, 2010; Carbonelli y Mosqueira, 2008).

Las noticias sobre la gran concurrencia de fieles en los actos evangélicos también dieron cuenta de la inquietud de los sectores religiosos tradicionales -el catolicismo principalmente- por el fenómeno de la pérdida de fieles. Este fue uno de los tópicos principales en la reunión de la CELAM, la que contó con la presencia de Benedicto XVI en Aparecida, Brasil, durante 2007 y en la que el cardenal Jorge Bergoglio tuvo un rol destacado.

Respecto a los cultos afroamericanos como los Umbanda, ha sido señalada su estigmatización por los medios (Frigerio, 1993). En Clarín y CL.COM hubo cierta recurrencia informativa que daba visibilidad y clasificaba como casos policiales acontecimientos relacionados con cultos afroamericanos y su tratamiento como sectas (por ejemplo: Detienen a un pai umbanda que prostituía a sus fieles, edant.clarin.com/diario/2009/04/03/policiales/g-01890234.htm). En general, el corpus con el que trabajamos daba cuenta de estos fenómenos ${ }^{71}$.

En cambio, los casos de pedofilia en la Iglesia Católica (por ejemplo, caso Grassi) u otro tipo de abusos relacionados con lo religioso, rara vez fueron clasificados y publicados en la sección policial.

A partir de la configuración formal y las temáticas recurrentes de las noticias que tratan sobre religión podemos dar cuenta de las puestas en escena que la prensa escrita conjuga entre palabras, imágenes, diseño, y propone tanto desde los diarios impresos y los diarios digitales aunque con la permanencia de sus distinciones específicas entre soportes y dispositivos mediáticos diferenciadores (Traversa, 2001; Scolari, 2004, 2008).

\footnotetext{
${ }^{71}$ El listado de titulares de las noticias de clarín.com de nuestro corpus en la palabra clave Pai, entre 2001 y 2010, está prácticamente relacionado con la sección policial: Cae un pai umbanda acusado de descuartizar a dos mujeres, Tigre: detienen a un pai umbanda acusado de asesinar a dos mujeres, Detienen a un pai umbanda que prostituía a sus fieles, Todo por amor: pagan hasta 3.000 pesos por recuperar 0 mantener a una pareja, Perpetua para un pai umbanda que descuartizó a una mujer, Juicio oral a un pai umbanda por descuartizar viva a una mujer, Lo matan y usan su sangre para un ritual umbanda, Delitos y Justicia, Hallan armas y huesos humanos en la casa de un pai umbanda, Asaltan y matan de un balazo a un pai umbanda y remisero, Creen que un pai umbanda es el asesino de dos amigas, Descuartizan viva a una mujer en su departamento, Detienen en La Plata a una asistente de la Procuración, Un pai reclama $\$$ 2.575.000 por torturas en una investigación, Seis detenidos por robar a pasajeros de taxis, Juicio oral con la Biblia y el calefón, Los rituales de los delincuentes antes y después de cada golpe, Detienen a un ex guerrillero por los robos a 70 cajas de seguridad
} 
A grandes rasgos, Clarín y CL.COM se caracterizan por presentar como parte de su estilo esa posición distanciada de la que hablamos más arriba y que pretende cierta objetividad periodística que luego será contradicha por la selección de sus estrategias narrativas, por sus jerarquizaciones y presentaciones de la información de actualidad, en las que necesariamente toman posición.

La importancia que Clarín y CL.COM otorgan a la Iglesia Católica es atribuible a un actor social que, en sus llamados y alocuciones a la sociedad, puede ejercer fuerte presión política y moral sobre los gobiernos -en gran medida, gracias a su visibilidad en los medios, por eso hablaremos de alianza entre ambos- al instalar posibles climas y temas de opinión pública ${ }^{72}$.

A su vez la posición pública del Episcopado católico argentino, en el ámbito de la educación y los derechos sexuales y reproductivos, ejerce presiones y trata de mantener una visión y valoración estática de la sociedad al oponerse a la mayor parte de los cambios legislativos que se discutieron en el Congreso Nacional (Esquivel y Vaggione, comps., 2015).

Así, la injerencia de los cultos religiosos en las decisiones políticas de los gobiernos ha sido observada como algo "normal" y habitual por los diarios de referencia dominante $^{73}$. A excepción de Página/12 y P12.COM, que históricamente han tratado este tipo de informaciones con ironías críticas en referencia a esas naturalizaciones mediáticas en las relaciones políticas argentinas.

Durante nuestro período de estudio (2001-2010), una de esas naturalizaciones mediáticas tuvo relación con la asistencia social en cuanto a la presencia de la Iglesia Católica como protagonista en la distribución de la ayuda, especialmente, en la crisis de fines de 2001 y en la Mesa de Diálogo de 2002.

\footnotetext{
${ }^{72}$ Uno de estos temas recurrentes en el período indagado fue el de la pobreza, que tuvo su punto de mayor tensión con las repercusiones locales por las declaraciones de Benedicto XVI en 2009 -más allá de cómo se interpretaron esas declaraciones-, acompañado en los medios por la regular publicación de un índice de pobreza elaborado por la Universidad Católica Argentina desde 2002 http://www.uca.edu.ar/index.php/site/index/es/uca/observatorio-de-la-deuda-socialargentina/presentacion/.

${ }^{73}$ Los diarios de referencia dominante (Albornoz, 2006: 17-29) representativos de los sectores sociales en el espacio público argentino los llamamos así dado que con las ediciones digitales, otra de sus reconfiguraciones es la de su "alcance": nacional, regional, local, al hacer difusas esas fronteras espaciales que estaban asociadas a la distribución física de los impresos en el país. Además, esos diarios cuentan con la figura de periodistas especializados en el tema religioso, que firman sus notas y que realizan un seguimiento sistemático de las relaciones entre religión y política -en sentido amplio.
} 
Históricamente, Caritas es una de las organizaciones sociales con larga trayectoria en la asistencia social, aunque también existe un servicio social de la Asociación Mutual Israelita Argentina (AMIA) y otro del Ejército de Salvación relacionado a los protestantes metodistas, que han tenido un rol participativo en la ayuda social durante la crisis de 2001. Los medios de referencia dominante, sin embargo, cada año sólo insistieron en la difusión de la colecta Más por Menos organizada por Cáritas en sus coberturas y tratamientos informativos.

\subsubsection{Formas y formatos mediáticos}

Otros rasgos formales que podemos destacar en la configuración de Clarín tienen relación con el formato tabloide de la edición impresa, que lo ubica con su predominancia informativa y coloca a este medio de comunicación como objeto comercial de presencia ubicua en la vida cotidiana. Suele considerarse que este formato impreso permite su lectura en los medios de transporte, en tensión con el formato sábana, del que suele decirse que requiere el despliegue sobre un escritorio para su lectura $^{74}$.

Además, podemos considerar la aparente seriedad y solemnidad de la "prensa blanca" (Steimberg, 2013: 167-177) de La Nación frente a los juegos de sentido en el diseño gráfico de Página/12. En cambio, Clarín se autopresenta como el diario nacional de mayor tirada, como representante de una clase media amplia -que en otro tiempo fuera considerada "masiva" y "popular"-, y supuestamente distanciado respecto a las orientaciones políticas y/o religiosas -a diferencia de La Nación y Página/12, y del posicionamiento político explícito que realizan otros medios en otros países, por ejemplo, el New York Times en USA.

También puede señalarse que algunos rasgos del estilo de Clarín se han extendido a otros medios del Grupo Clarín que es propietario de Canal 13, Radio Mitre, la agencia de noticias Diarios y Noticias (DyN), parte de la empresa papelera Papel Prensa, las empresas de televisión por cable Cablevisión y de internet, Fibertel, entre

\footnotetext{
${ }^{74}$ En 2016 La Nación modificó por primera vez en su historia el formato sábana a uno tabloide aunque el diseño y diagramación de la edición impresa conservó su similitud en el nuevo tamaño.
} 
muchas otras, y cuya posición monopólica fue cuestionada públicamente a partir de la sanción de la Ley 26.522 de Servicios Audiovisuales, conocida como Ley de Medios ${ }^{75}$.

Esta actuación corporativa de los medios del Grupo Clarín también ha permitido que CL.COM se posicione no sólo como un diario digital, sino como un portal de acceso a una cantidad de empresas noticiosas y de servicios de entretenimiento que se encuentran relacionadas, con sitios y enlaces disponibles en la propia portada del diario digital.

\subsection{Portadas impresas y digitales}

Sin embargo, más allá de los formatos, por donde el ojo entra en contacto con la información del diario impreso es la tapa o portada (Steimberg y Traversa, 1997). En los diarios digitales continúa existiendo una "portada" que es la de cada sitio de noticias. Aunque ha perdido el peso de la tapa impresa, la jerarquización de sus títulos continúa vigente en el tamaño tipográfico y en el orden de la lectura; incluso la espectacularidad que tenían las fotografías en la prensa llamada popular o "sensacionalista" ya no es una característica prioritaria que, entre otros rasgos, defina ese estilo.

En la portada digital gana espacio la posibilidad de actualización de las noticias, de corrección, de ampliación y reenvío a la información disponible en la web, de sus interacciones con redes sociales y otros sitios web. Incluso la portada puede presentar una sola fotografía que ocupe la pantalla, como sucedió en CL.COM y LN.COM al conocerse que el cardenal y arzobispo de Buenos Aires, Jorge Bergoglio, fuera electo Papa Francisco.

Si la portada impresa es por donde el ojo entra al mundo informativo, en cada título de cada noticia, de la edición digital habrá también un contacto específico para cada lector posible, una decisión en espera, una continuidad o un salto en el "hacer clic" (Scolari, 2004, 2008) que implica el uso del hipervínculo en la lectura, un acuerdo, un conflicto o, porque no, una indiferencia.

\footnotetext{
${ }^{75}$ http://www.infoleg.gov.ar/infolegInternet/anexos/155000-159999/158649/norma.htm Consultado: 18 de mayo de 2016.
} 
La enunciación del medio, impreso o digital en este caso, presupone desde su portada la identificación de su estilo mediático con el estilo asumido por el posible lector; después, la lectura podrá ser "oposicional" o negociada, como sostenía Hall (1996), resginificada (como afirmaban Martín-Barbero, 1991; Canclini, 1990), pero habrá que estudiarlo en recepción o en las llamadas condiciones de reconocimiento (Verón, 1987, 1993, 1997; Saintout y Ferrante, 2006).

\subsection{Títulos}

Los títulos de Clarín y CL.COM despliegan uno de los lugares privilegiados de contacto posible entre la información y el lector. La repetición de palabras que forman lugares comunes en los títulos de cada noticia, ya sea por referencia a acontecimientos anteriores en la continuidad informativa o ya por indicadores lingüísticos, asegura la comprensión de los temas presentados, el grado de su novedad, de su interés, de su expectativa, que se amplía a partir de los subtítulos y las volantas, los copetes, los recuadros y el cuerpo principal del texto e incluso con las imágenes fotográficas, epígrafes, infografías, diagramas y cuadros.

A diferencia de Página/12 y P12.COM, la ironía no es una invitada habitual entre los títulos de Clarín y CL.COM. La aparente construcción de "objetividad" periodística -diríamos mejor de una supuesta "neutralidad" con las fuerzas y sectores sociales- requiere la supuesta "claridad" y concisión de lenguaje. Incluso en los casos en los que el título presenta la declaración en cita directa de algún actor social, cuando alude a qué, quién, dónde, cuándo, por qué, cómo o para qué ${ }^{76}$.

\footnotetext{
${ }^{76}$ Las famosas $5 \mathrm{~W}$ de la información remiten al inglés who, what, where, when, why, es decir quién, qué, dónde, cuándo, por qué, a las que a veces se le agrega how, cómo. Los manuales de periodismo prescriben que entre título, subtítulo (o bajada) y primer párrafo (o copete) deberían estar agotadas estas cinco preguntas en cualquier noticia. El periodismo "tradicional" (aproximadamente 1850-1950) recomendaba sintetizar las respuestas a las cinco preguntas en el primer párrafo, también llamado "copete", en inglés lead (encabezado), y continuar el desarrollo de la noticia en orden de importancia para que, si faltaba espacio, el medio o el telégrafo cortara la información y no se perdiera lo más importante por falta de espacio o tiempo. Todo esto tiene muchas objeciones ya que la práctica desborda al pequeño modelo de las $5 \mathrm{~W}$ y siempre hubo por suerte excepciones notables, pero se ha desarrollado así históricamente en su relato y ha dado forma a un estilo periodístico que se reclama más "objetivo" que el Nuevo Periodismo de la década de 1960 y 1970. El periodismo "tradicional" también se hizo presente en los modos de la lectura de noticias en la radio de la primera mitad del siglo XX y en la televisión, incluso en la prehistoria de la televisión con los primeros noticieros cinematográficos (Gomis, 1991; Martín Vivaldi, 1973; Rodrigo Alsina, 1993; Verón, 1996, III Conferencia).
} 
Como hemos dicho el estilo de Clarín y CL.COM el periodismo "independiente" consiste en adoptar esa supuesta posición pública "neutral”, que depende de la negociación y la puja con los sectores sociales más visibles. No tanto porque no se admitan las presiones políticas, las relaciones empresariales, los "intereses", sino porque desde la lógica y el punto de vista periodístico del Grupo Clarín, justamente el periodismo debe ejercerse pese a esas presiones o "intereses" y Clarín aparecería como mediador en esa puja (Sivak, 2015; Mochofsky, 2011).

Esta es una concepción representacional que concibe a los medios como "espejo" de la realidad social, cuando es notoria y visible su actuación cada vez mayor como instituciones y actores políticos (Borrat, 1989) que tienen un rol en la sociedad, no sólo de mediación sino también de participación e intervención; en especial, a partir del fenómeno que hemos descripto bajo el término mediatización (Verón, 2001b; 2013).

\subsection{Subtítulos o bajadas}

En Clarín y CL.COM, la bajada suele actuar como nexo entre la volanta ubicada encima del título y el primer párrafo, llamado copete en la jerga periodística. Es una relación de explicación que vincula distintos componentes de la noticia, que amplía y compensa la escasez informativa del título por su falta de espacio, y en el que generalmente el verbo que orienta la acción del acontecimiento suele estar destacado en la noticia.

La bajada ocupa en general dos o tres líneas en la diagramación, tanto digital como impresa, y es el lugar textual de la noticia donde es posible presentar recursos para captar y reforzar la atención del hipotético lector hacia la información.

La bajada en este sentido puede ser interpretativa del acontecimiento, explicativa respecto al lector construido por el texto (que nosotros llamamos enunciatario [Steimberg, 1993, 2013]) y generadora de expectativas para favorecer la continuidad de la lectura. Es necesaria la hipótesis mediática acerca de que "del otro lado" hay alguien a quien le va a interesar lo publicado: un lector modelo que "coopera textualmente" con el medio de comunicación en su lectura, para decirlo en los términos de Umberto Eco $(1996,1993)$. 
A diferencia del discurso político, por ejemplo, el discurso de la información periodística de actualidad no construye un "contradestinatario" (Verón, 1987). En pocas ocasiones el discurso informativo de prensa escrita le habla a un supuesto adversario; en general, se orienta al conjunto de todos los "ciudadanos" (en cada caso puede variar lo que entienda por ciudadano) y es un discurso que se supone inclusivo, aún en el caso en que se dirija a un fragmento del público.

Dijimos antes que es destacable que las noticias sobre religión no presenten particularidades diferenciadoras respecto al resto de las informaciones en su configuración formal. En cambio, podemos afirmar que en la sección política hay un predominio de notas de análisis; en la sección economía, de datos y estadísticas presentes en notas que tienden hacia el formato del informe; que la sección cultura cuenta con mayor presencia de reseñas y entrevistas; que en la sección deportiva predomina la crónica como relato de los partidos y juegos.

Entonces no podemos decir que en las noticias sobre religión haya una particular forma de tratamiento de la información. O para decirlo de otro modo, las noticias sobre religión no instituyen suficiente previsibilidad genérica para organizarse en una sección noticiosa: las noticias que tratan sobre religión atraviesan diversas secciones y suelen involucrar temáticas compartidas por la política, la economía, la sociedad, entre otros rótulos diferenciadores de las secciones en la prensa escrita.

Tanto el diseño como la extensión y presentación de las notas sobre religión tienen las mismas características que las noticias sobre otras temáticas; lo interesante es el cambio de tema que acentúa la información sobre fenómenos de religiosidad, las "novedades" (en el sentido del material noticiable) que introduce, la representación de actores sociales, la construcción de espacios públicos de enunciación y los posibles destinatarios a los que se orientan sus textos. En particular, las construcciones enunciativas en las que la temática de noticias sobre religión conecta de manera sensible con el estilo y con la línea editorial de cada medio.

\subsection{Secciones}

En continuidad con el apartado anterior, decíamos que la temática religiosa en Clarín y CL.COM no construye una sección propia, pese a que podría hacerlo: no hay 
inconvenientes desde el punto de vista técnico, ni en el diario de papel ni en el diario digital, para que sea posible ${ }^{77}$.

Sin embargo, La Nación y LN.COM tienen una subsección llamada Actualidad Religiosa y también suelen publicar, en la edición impresa, un recuadro breve titulado Culto Católico donde el diario presenta informaciones a modo de anuncios sobre diversos acontecimientos relacionados con el catolicismo: celebraciones, presentaciones de libros, conciertos religiosos, fallecimientos, declaraciones, conmemoraciones, cursos, festejos, entre otros. Esta suerte de "cartelera" de anuncios que también puede hallarse transpuesta en la edición digital del diario, no existe en Clarín ni CL.COM ni en Página/12 ni P12.COM.

En Clarín y CL.COM como en Página/12 y P12.COM, las noticias sobre religión forman parte de las secciones habituales de cada medio: política, sociedad y opinión, principalmente, aunque puedan variar de acuerdo al tipo de noticia que se trate.

Si bien hemos señalado (supra, 1. Introducción y 3. Presentación conceptual) el caso paradójico del suplemento Valores religiosos en Clarín y CL.COM ${ }^{78}$, se trata de una publicación avalada por la asociación católica sin fines de lucro bajo el mismo nombre, el suplemento acompaña al diario de papel y tiene un espacio propio entre las columnas y noticias del diario digital, al menos, desde $2004^{79}$.

\subsection{Noticias}

\footnotetext{
${ }^{77}$ Pese a que advertimos acerca de la insuficiente previsibilidad genérica faltan elementos para explicar el fenómeno llamativo -por su ausencia, por la falta de tentativas- de que en el periodismo argentino no se haya constituido una sección temática específica de noticias sobre religión -ni siquiera luego de la asunción del Papa Francisco. Aunque pueda hacerlo o pueda haber existido en el pasado, en el que sí hubo varios diarios y revistas dedicados a lo religioso. Mencionamos antes la referencia al caso del diario español $Y a$, publicado en Madrid, que contaba con una sección fija titulada "Iglesia postconciliar" y que indicaba la importancia otorgada por ese medio a las transformaciones introducidas tras el Concilio Vaticano II (Martín Vivaldi 1973: 236).

${ }^{78}$ El diario no indica que se trate de un espacio pago como afirmó el periodista Sergio Rubin cuando lo entrevistamos, así que hay una ambivalencia en la asunción del suplemento como "propio" del diario, dado que tampoco es publicado como un espacio publicitario o promocional. Esa ambivalencia, la hemos notado como parte de las estrategias institucionales del medio frente al Estado y a la Iglesia Católica.

${ }^{79}$ El caso del suplemento Valores Religiosos demuestra una de las estrategias recurrentes en la historia de la Iglesia Católica argentina. Al crear una asociación que promueve un suplemento publicado en el diario Clarín y CL.COM, al mismo tiempo pretende representar la diversidad religiosa pero no deja de estar propiciado por el catolicismo y por un medio de comunicación hegemónico. Es decir, el catolicismo argentino muchas veces se confunde con el Estado y con los sectores hegemónicos en su búsqueda y conservación de las relaciones de poder en la sociedad argentina.
} 
Las noticias que tratan los fenómenos de religiosidad pueden variar desde un caso policial a una procesión popular, desde la declaración de un líder religioso a un encuentro litúrgico. El editorial, la columna de opinión, la nota de análisis, la crítica, la entrevista, la crónica, son géneros que en cada diario hacen sistema en sincronía (Steimberg, 1993, 2013) y que se diferencian entre sí por valores opositivos. Aunque en un sentido amplio, la mayoría de las informaciones producidas y publicadas son llamadas por igual noticias ${ }^{80}$.

La regularidad de las noticias sobre religión estaría marcada por la previsibilidad social que, sobre la agenda de temas, construye el diario: los espacios que proponen las secciones, las temáticas recurrentes y dominantes, los contenidos específicos que en cada período temporal involucran diversos acontecimientos, además de las decisiones editoriales de cada medio y la importancia con la que defina, en su estilo, a las temáticas sobre religión.

En nuestro objeto y período de análisis, incluso un diario como Página/12 y P12.COM por más que tenga posiciones a favor del laicismo, no puede escapar -ni por la negativa ni por la crítica- de hablar sobre los acontecimientos religiosos; lo hace necesariamente porque las temáticas sobre fenómenos de religiosidad atraviesan y se combinan con las demás temáticas y secciones de las noticias ${ }^{81}$.

Difícilmente cualquiera de las noticias sobre fenómenos de religiosidad pueda escapar y no involucrar a las secciones de política, sociedad e información general, consideradas las secciones "mayores" de la prensa gráfica tradicional; de allí, sus ambigüedades respecto a las clasificaciones en las rutinas productivas del periodismo.

\footnotetext{
${ }^{80}$ En este amplio sentido, entendemos que las noticias se oponen y diferencian de la publicidad, los avisos sociales y los clasificados, al menos en el diario tradicional de papel. No nos interesa tanto una definición de la noticia -hay muchas-, aunque estamos de acuerdo en diversos aspectos de las caracterizaciones relacionales acerca de la noticia, principalmente con Rodrigo Alsina (1993). También puede consultarse con una perspectiva interesante sobre la relación de los comentarios de las noticias en: Gomis (1991) y Charadeau (2003), quien enfoca el discurso de la información de actualidad periodística con diferenciaciones tipológicas sobre otro tipo de discursos e informaciones. En Construir el acontecimiento Eliseo Verón realiza un análisis sobre una cobertura periodística centrado en la noción de acontecimiento y mediatización en la construcción de las noticias.

${ }^{81}$ Es interesante como ejemplo que en sus comienzos y durante varios años, Página/12 no tuvo sección sobre deportes. Si se trataba el tema lo hacía Osvaldo Soriano desde la sección de Cultura o desde las otras secciones. Esto cambió con la sección Líbero aunque todavía hoy P12 y P12.COM le dedican un espacio reducido al deporte -en comparación con otros diarios- y un espacio mucho mayor que sus colegas a las temáticas de la cultura. Es decir, que no modificó su estilo aunque tuvo que incluir la sección deportiva.
} 
También, en el caso del diario digital hay cambios en el emplazamiento del soporte físico que se relacionan con los modos de presentación de las noticias que permite el entorno informático junto con herramientas novedosas como el etiquetamiento ("tags"), los ránkings de noticias más leídas, la proliferación de secciones y sub-secciones, así como la posibilidad de relacionar en un mismo espacio digital a las revistas y productos de cada grupo mediático con el diario.

Las noticias sobre religión forman parte de la agenda de los medios en el largo plazo porque los diarios - tanto digitales como impresos- ofrecen entre sus temas una continuidad informativa sobre los acontecimientos religiosos, con periodistas especializados que se ocupan de las temáticas sobre fenómenos de religión y, además, porque esas temáticas son previsibles en la construcción del género noticias -como “correas de transmisión" (Bajtín, 1982) entre la cultura y la historia-, y de su flujo informativo entre las que podemos destacar:

- las celebraciones religiosas que marcan el tiempo de lo social en los diversos cultos -aunque no con el mismo criterio de importancia, ni de proximidad, interés y actualidad-, son componentes de la selección del material noticiable;

- las procesiones populares que se repiten cada año y construyen informaciones de actualidad sobre ciertos modos de religiosidad "popular";

- las informaciones periodísticas sobre la liturgia y la doctrina religiosa "oficial" de cada religión, en particular, de las religiones tradicionales;

- las informaciones periodísticas sobre la relación que existe en la Argentina entre los cultos religiosos y la asistencia social estatal que ubica a esos cultos como organizaciones sin fines de lucro y participan de ese modo en diferentes programas y líneas de acción estatal, además de beneficios impositivos a los cultos reconocidos y aprobados por el fichero de la Secretaría de Culto de la Nación y privilegios del culto católico por su condición excepcional otorgada por la Constitución de la Nación;

- por último, las informaciones periodísticas de actualidad sobre las injerencias de los diversos cultos en materia de educación, sexualidad, derechos y obligaciones de las personas a través de la influencia que puedan tener en las familias creyentes, en las costumbres y leyes que regulan a la sociedad. 
Por estas y otras razones, las noticias sobre religión tienen una presencia continua en los diarios impresos y digitales argentinos que podrían constituir, en algún momento, una sección propia. Estos contenidos específicos marcan la regular presencia de noticias sobre los credos principales en el caso de la Argentina: el catolicismo, el judaísmo, el islamismo ${ }^{82}$.

\subsection{Temáticas}

Nos preguntábamos antes, ¿de qué están formadas las noticias sobre religión y por qué no suele haber una sección específica en los medios sobre esta temática, como sí la hay sobre política, economía, deportes, todas secciones que enuncian su tema?

En primer lugar, podemos decir que los contenidos específicos forman los "motivos" (en el sentido musical del leitmotiv, y en el sentido pictórico de fragmento que se repite [Steimberg, 1993; Segre, 1985]); esos contenidos específicos son a los que aludíamos al comienzo: qué acontecimientos tratan, cuándo sucedieron, entre quiénes, de qué manera, para qué y por qué, cómo ${ }^{83}$.

Las noticias que forman parte del corpus de análisis son aquellas que se han recolectado a partir de las siguientes palabras clave:

Aborto- Aguer- Bergoglio- Biblia- Budismo- Cardenales- Caritas- Casaretto- CEACELAM- Educación sexual- Evangélicos- Iglesia Católica- Igualdad religiosa- ImánJudíos- Ley de Cultos- libertad de cultos- libertad religiosa- Obispado castrenseObispo- Obispos latinoamericanos- Pai- Pastor Evangélico- Rabino- Secretaría de Culto- Sectas- Te Deum- Umbandas- Vaticano

Y que organizamos en dimensiones analíticas:

Educación sexual- Planificación familiar- Aborto- Estado/Iglesias- Vaticano- Asistencia social- Religiosidades populares- Cuestiones doctrinarias- Matrimonio igualitarioEducación religiosa- Diversidad religiosa

\footnotetext{
${ }^{82}$ No podríamos afirmar lo mismo respecto a lo que sucede en revistas, radios y televisión sin hacer un análisis específico de esos medios.

${ }^{83}$ Mencionamos ya, en una nota anterior, las $5 \mathrm{~W}$ de la información que no son más que las preguntas básicas de una investigación social. La práctica del periodismo debiera sustentarse en las ciencias sociales si no queremos que dependa sólo de las creencias aceptadas y del sentido común dominante en una sociedad. Tal vez, por ese motivo sería importante repensar la función de los colegios y las exigencias deontológicas para el ejercicio del oficio del periodismo.
} 
La selección de cada información para el armado del corpus tuvo que ver con la pertinencia de la noticia respecto a la palabra clave y a las dimensiones de análisis propuestas, además de su relación con el recorte temporal que supuso el período 20012010, y la localización en los archivos digitales de clarin.com, lanacion.com y pagina12.com.

\subsection{Editoriales}

Los editoriales de Clarín y CL.COM, La Nación y LN.COM -Página/12 y P12.COM no suelen publicar sección editorial- que aludieron a las temáticas religiosas solían hacerlo al retomar alguna advertencia del Episcopado Católico al gobierno, en materia política, o por alguna deficiencia en el funcionamiento estatal. Estos diarios también han editorializado sobre la pedofilia y la Iglesia Católica.

El editorial aparecía en menor medida con respecto a los demás cultos. A veces para saludar alguna celebración de las religiones llamadas "universales" (islamismo, judaísmo, protestantismo), o también para advertir respecto a nuevas creencias, prácticas o movimientos religiosos, publicaban noticias donde se los calificaba de “sectas" o "New Age" (Nueva Era).

Por su tono y su configuración, el editorial es un tipo de texto que presupone la puntualización de la relación entre el medio y el lector. Sin embargo, en el periodismo es habitual considerar que el editorial también es un género políticamente correcto, por lo general escrito por un periodista en las sombras y firmado por el director-propietario del medio como propio.

Es decir, el editorial contemporáneo es un tipo de nota periodística que en casos excepcionales pronunciará advertencias, sanciones, al modo en el que los grandes diarios del siglo XIX pretendieron formar al ciudadano, a través de la educación cívica, para que con su voto se convirtiera en el soberano elector político de sus gobernantes (Price, 1994).

En los casos de Clarín y CL.COM, La Nación y LN.COM observamos que el editorial funciona como describimos antes: un tipo de texto que se publica diariamente y que presupone la opinión representada del medio. 
En cambio, Página/12 y P12.COM carece de editorial y diariamente utiliza un suelto de página que publica en la portada impresa ${ }^{84}$. La contratapa y las columnas de opinión política y económica firmadas por periodistas del medio cumplen con la función editorializante que tiene la opinión publicada.

La función editorial no se pierde, se expande a otras áreas del diario al proponer en el estilo de Página/12 y P12.COM una relación distinta con el posible lector. Es diferente $^{85}$ respecto a la que proponen los medios nacionales de referencia dominante (Albornoz, 2006) que construyen la agenda y en oposición a la prensa tradicional, es decir, cercana al estilo del Nuevo Periodismo de fines de la década de 1970.

En el ámbito de las ciencias sociales argentinas, Sidicaro (1993) intentó analizar en los editoriales, las "ideas" del diario La Nación. Podríamos decir que abordar las “ideas" no es una tarea fácil; presupone que haya algo así como una "cabeza" del diario y que haya una traducción directa entre el pensamiento y el lenguaje de esa cabeza.

Pero un diario no es siquiera la representación de una mente sino un objeto de materialidad sígnica y física compleja, una organización institucional (Verón, 2004, 2013) al modo en que lo son los objetos culturales. Aun si aceptáramos la metáfora y consideráramos las existencias materializadas de los signos como representación de las ideas, entonces habría que reconocer que esas "ideas" podrían estar presentes en cualquier otro fragmento del diario y no necesariamente en el editorial.

Sin embargo, es cierto que uno de los efectos de sentido propuestos por el género editorial -en su propuesta textual a lo largo del tiempo- construye la relación de representación de las valoraciones, las opiniones, representaciones y creencias posibles del medio para con su lector modelo (Eco, 1993). De ahí tal vez surge la metáfora que corresponde al momento fundacional de los diarios argentinos, en el siglo XIX.

Resumiendo y más allá de la crítica metodológica, podemos decir que de los tres diarios seleccionados La Nación y LN.COM mantienen editoriales convencionales en sus páginas y sitio web. Página/12 y P12.COM no tuvieron editorial desde su nacimiento -tanto impreso como digital- al menos en el sentido tradicional del género,

\footnotetext{
${ }^{84}$ En la edición digital del diario sólo es visible si el lector se dirige a la sección "tapas" que presenta la portada del día con la versión "edición impresa" en internet, ya hemos hablado acerca de la paradoja que presupone este uso del diario digital.

${ }_{85}$ A tal punto, que en 2016 este medio comenzó a utilizar el slogan "La otra mirada" en sus publicaciones.
} 
porque muchas veces el chiste de portada, las columnas de opinión, las contratapas y los fotomontajes "editorializan" la información. A esto se suma el intenso componente interpretativo que posee este diario, en el que cada periodista firma su nota y tiene cierto margen textual para incluir la opinión y la ironía.

En el caso de Clarín y CL.COM, si bien durante algunos períodos tuvieron editoriales convencionales que se publicaban junto con las principales columnas de análisis político y económico, en particular en la edición impresa, en los últimos años varios editores se turnaron en la redacción de una breve nota firmada en la edición digital llamada "Del editor al lector".

Se trata de la opinión de editores de sección donde puntualizaban alguna información conectada con esa jornada, o con algún tema de relevancia nacional proveniente de las secciones de política, economía, sociedad, policiales o internacionales.

\subsection{Notas y columnas de opinión}

Si bien la opinión en una nota o columna suele representar a la figura que la firma, no deja de ser cierto que esa firma al ser seleccionada por el diario también lo representa a éste. Tal como decíamos que la función editorial puede estar presente en diversos fragmentos del texto $\mathrm{y}$, establecer así, un vínculo de delegación entre la representación de quien opina y la opinión del medio: el principal enunciador suele ser el medio, y es él quien habilita la distribución de la palabra a los especialistas para dirigirse desde columnas o notas de opinión, para enunciar desde sus páginas.

Con los diarios digitales hubo en los últimos años una multiplicación de los especialistas que puede ser comparada con lo sucedido en la historia de otros medios como la radio y la televisión (Verón, 2001b, 1997: III Conferencia). También es cierto que en los diarios digitales, las columnas y notas de opinión suelen permanecer durante algunos días, e incluso el lapso de una semana entera, en los sitios web de algunos medios ${ }^{86}$.

\footnotetext{
${ }^{86}$ En nuestro período de estudio estos funcionamientos son variables pero a grandes rasgos podemos señalar que clarín.com tendió a actualizar rápidamente sus contenidos, página12.com mantuvo las notas de sus columnistas en el período de la semana y lanacion.com cambió de acuerdo a la diferenciación entre
} 
En cambio, la repetición en la publicación de una columna no es habitual en la concepción del diario de papel que trabaja ligado a lógica de la novedad y en la que, luego de esa jornada, la información perece. El diario impreso es un objeto ubicuo, que pasada su periodicidad es usado más como papel para encender un fuego o envolver verduras, que como 'objeto diario' (Scolari, 2008; Boczkowski, 2006; Valdettaro, 2009) a excepción del archivo que realizan las hemerotecas.

El diario digital reutiliza la información ya desde el momento en que posee un archivo en su mismo sitio de noticias, y hasta que la temática noticiosa se agota. Además de las habituales columnas de política y economía, aparecen muchos temas específicos como finanzas o psicología, medicina o terapias alternativas que pueden ser tratados desde múltiples puntos de vista en el diario digital, que no tiene las limitaciones físicas ni de espacio del centimetraje del diario impreso.

Las columnas y notas de opinión firmadas por líderes religiosos católicos son habituales en La Nación y lanacion.com. Con mayor distancia, en Clarín y clarin.com pueden aparecer notas periodísticas firmadas por algún líder religioso entre un conjunto de especialistas; por ejemplo, en la discusión de las leyes de Educación Sexual entre 2004 y 2006. Entre los especialistas aparecía la representación de voces de la Iglesia Católica y también del protestantismo y judaísmo, que suelen gestionar escuelas privadas confesionales, y subsidiadas por el Estado.

En Página/12 y pagina12.com, en cambio, no sucede lo mismo: en el corpus seleccionado no se han observado con regularidad notas o columnas firmadas por religiosos -excepto por algún intelectual relacionado con lo religioso, como los ex sacerdotes de la Teología de la Liberación, Rubén Dri o Leonardo Boff- pero sí aparecen entrevistas a líderes religiosos, especialmente a Jorge Casaretto ${ }^{87}$, en las que los títulos suelen ser declaraciones tomadas de las entrevistas -que funcionan en el sentido del reportaje, como retrato de la personalidad entrevistada.

los días de semana y los días del fin de semana, con una fuerte presencia de las columnas de opinión y análisis así como de los suplementos, en el fin de semana o en los días previos.

${ }^{87}$ Según Washington Uranga, la recurrencia de la figura de Casaretto en este medio se debía al acceso que el periodista especializado en religión tenía con el líder religioso en aquél momento, según nos dijo en la entrevista que le realizamos. De todas maneras, es llamativo cómo el estilo "progresista" se retroalimenta -tal vez, por el carácter de las referencias múltiples y complejas de lo simbólico (Goodman, 1990)- en cuanto a que sea la figura del obispo de San Isidro la que mayor visibilidad tuvo en P12 y P12.com, en el período indagado. El sólo hecho de colocar de manera recurrente un entrevistado en la sección reportajes produce estas asociaciones sígnicas. La acción de la representación en los medios tiene mucho que ver con estas puestas en escena por proximidad, que construyen significaciones y figuraciones específicas. 


\subsection{Géneros informativos/opinativos}

Los géneros periodísticos se hacen evidentes más por su circulación y su uso social que por las definiciones que los periodistas tratan de establecer a partir de su práctica $^{88}$. Paradójicamente, el periodismo suele acentuar el aspecto del carácter productivo que permiten los géneros, más que el uso que cada sociedad instituye en su circulación, recepción y consumo.

Nosotros seguimos la propuesta teórica de la definición de géneros y estilos que plantea el semiólogo argentino Oscar Steimberg (1993, 2013). Esta tradición parte de una corriente inaugurada en la contemporaneidad por Bajtín (1982) pero que en sus lejanos comienzos puede remontarse hasta la Poética de Aristóteles, al establecer diferencias sistemáticas en el uso social de los géneros y de los estilos.

Diferencias y similitudes que producen y reconocen las sociedades, y que permiten agrupar objetos culturales en clases de textos. Sin esa producción y reconocimiento que hace una sociedad histórica y socialmente determinada no podría funcionar el sistema de clasificación de textos en géneros discursivos que, al decir de Bajtín (1982), actúan como "correas de transmisión entre la historia y la lengua"; tampoco lo harían las clasificaciones de textos por sus oposiciones estilísticas (Steimberg, [1993] 2013; Diéguez, 2011).

Como en nuestra indagación partimos del material empírico recolectado en el corpus de análisis, podemos decir que en las condiciones de producción (Verón, 1993) de las noticias seleccionadas aparecen los géneros informativos de la crónica, la entrevista, la noticia propiamente dicha, en el sentido de lo nuevo y más importante que ha sucedido, $\mathrm{y}$, tal vez podríamos agregar aquí, el informe especial, el periodismo de investigación. En cambio, entre los géneros opinativos encontramos la columna y nota de opinión, el editorial, la crítica y la reseña.

Estos suelen ser los géneros que circulan en el corpus de noticias que hemos seleccionado y en los que pudimos establecer distinciones como el periodismo

\footnotetext{
${ }^{88}$ Un breve repaso por la bibliografía sobre géneros periodísticos (Gomis, 1991; Martín Vivaldi, 1973; Rodrigo Alsina, 1993; entre otros) da cuenta más del desacuerdo en relación a los géneros discursivos del periodismo y de la poca consideración de las relaciones entre estos con los estilos.
} 
interpretativo (Gomis, 1991), en relación con el movimiento llamado "Nuevo Periodismo" (Tom Wolfe, Truman Capote, pero también Rodolfo Walsh antes que ellos temporalmente), y que nosotros consideramos como un estilo enfrentado al "informativo" o prensa seria, también llamada blanca, por contraposición a la denominada "sensacionalista", adjetivada de amarilla o popular (Steimberg, 2013: 167177).

También podríamos utilizar una clasificación social frecuente en la que se le otorgan orientaciones políticas y se clasifica como periodismo "conservador" al de $L a$ Nación, que tendría el estilo de la prensa seria blanca; "progresista" e interpretativo al estilo de Página/12 y, "popular" -aunque no llegaría al supuesto sensacionalismo de Crónica -o Crítica, en el pasado- al de Clarín ${ }^{89}$.

Por supuesto, hay muchas clasificaciones sociales diferentes que se superponen, intercambian y a veces también califican a los medios de comunicación. La prensa especializada o la prensa gratuita, la prensa que depende de organismos e instituciones, la prensa "independiente"/"militante" son otros modos de nombrar los mundos sociales de referencia que también tienen sus lógicas de competencia en oposición, combinación, superposición, entre otras posibles producciones periodísticas.

La teoría de los géneros y los estilos se propone retrabajar esas clasificaciones sociales para encontrar los modos en que las sociedades clasifican sus objetos culturales.

\subsection{Narración, argumentación, descripción, comentario}

Si bien no lo señalamos en el apartado anterior, el predominio de la narración es uno de los componentes y rasgos de configuración que permiten reconocer a un género como el de la crónica, por ejemplo; en cambio, la argumentación suele predominar en los géneros de opinión. Desde ya afirmamos que no hay narración sin descripción, sin argumentación, sin comentario (Hamon, 1991); desde este punto de vista no existen ni los textos, ni los géneros ni los estilos "puros".

\footnotetext{
${ }^{89}$ No del mismo modo que Crónica o Diario Popular, para incluir a los cuales tendríamos que redefinir y ampliar la muestra entre diarios nacionales, regionales y locales, aunque la digitalización de los periódicos también ha modificado esto; volveremos sobre este asunto.
} 
Cada texto trae consigo una manera de inscripción estilística y es acreedor de, al menos, una -muchas veces no sólo una- posible inscripción genérica por más que su hacedor haya pensado bien distinto respecto a su obra o producto ${ }^{90}$.

La noticia acentúa la narración sobre el qué de lo sucedido, lo imprevisto del acontecimiento, su novedad a partir del interés social, proximidad o actualidad de eso que sucedió. La crónica lo hace sobre el cómo, en especial, cuando trata de sucesos que se desarrollaron a lo largo de una jornada, como una marcha política, una procesión religiosa, la elección de un Papa, etc. La entrevista articula la modalidad del diálogo pregunta-respuesta en los que narración, argumentación y descripción se intercalan con los comentarios opinativos, las afirmaciones y negaciones, las retomas del propio discurso o del discurso ajeno y la presentación de una escena enunciativa de diálogo, que puede estar centrada en el retrato del entrevistado, en sus declaraciones, en su calidad de especialista, en su actuación en el pasado, entre otras posibles.

El informe especial suele ser un formato que en vez de acentuar el componente de la actualidad, en el sentido del interés social, la proximidad, la urgencia, acentúa la profundización de una noticia o temática previa; por esto muchas veces se titulan a esos informes o secciones, "En Foco", “Zona”, "Enfoques". Es decir, hay un predominio de lo contrario a la noticia principal, de tomarse un tiempo para evaluar, analizar, contextualizar, considerar un tema, por lo cual la descripción, argumentación y el comentario evaluativo, fundado racionalmente, son característicos para este tipo de informes ${ }^{91}$.

Tal vez por eso se emparente con el periodismo de investigación que, en tanto género, más que una manera de hacer periodismo es un tipo de discurso en el cual se trata de evidenciar algo que estaba oculto, temas que por intereses sociales

\footnotetext{
${ }^{90}$ Nos referimos al discurso del autor y al debate sobre la intencionalidad autoral: el autor y el lector, o espectador, también quedan implicados en las relaciones sociales de producción-reconocimiento de los géneros y los estilos, pero estos al ser producto de la sociedad escapan en múltiples sentidos a las intenciones conscientes de los sujetos. Es interesante en nuestro caso cómo el estilo de la figura autoral de los periodistas muchas veces suele no ser considerado, ya sea porque subsume sus características en el estilo del medio para el que trabaja, o porque no suele ser diferenciado del de sus colegas; y asimismo, cómo los estilos más diversos se adaptan, reconfiguran y limitan en los estilos mediáticos. Pensemos en los diversos escritores y artistas que han trabajado en el periodismo argentino.

${ }^{91}$ Este tipo de modalidades discursivas y ordenamientos clasificatorios en secciones, justifica hasta cierto punto algunos aspectos de la ligazón entre periodismo, crítica, opinión pública y democracia. En los informes especiales, los diarios suelen poner en juego el periodismo de investigación, los sondeos de opinión, las notas de análisis, la defensa y participación del ciudadano... Véase Muraro (2000), Eagleton (1996), Habermas (1981).
} 
contrapuestos al interés público -ya sea corrupción, secreto de Estado, interferencias con un gobierno, etc.- no podrían darse a conocer, sacar a la "luz" pública (como insisten los manuales de periodismo que sí se ponen de acuerdo sobre este aspecto genérico).

A veces el periodismo de investigación se desarrolla en el informe especial pero por lo general, si el tema tiene impacto por proximidad e importancia para una sociedad determinada, el asunto que trata el periodismo de investigación se transforma rápidamente en una noticia principal que absorbe el espacio de otras secciones durante algún tiempo; esto es, lo que llamamos noticia propiamente dicha.

Entre los géneros opinativos, el editorial por supuesto acentúa la argumentación que, en combinación con la descripción y el comentario, puede calificar, amonestar y llamar la atención sobre un problema o cuestión social.

La columna de opinión o análisis suele tener una frecuencia regular de publicación y ser escrita por una figura cercana al medio - por eso su pluma suele editorializar- un especialista en política, economía o en algún tema social; las columnas de análisis político de Joaquín Morales Solá, Mariano Grondona o Beatriz Sarlo en La Nación y LN.COM solían ser habituales, así como las de Eduardo van der Kooy y Marcelo Bonelli en Clarín y CL.COM; de Edgardo Mocca, Horacio Verbitsky, Osvaldo Bayer, Mario Wainfeld o Sandra Russo en Página/12 y P12.COM.

En el último tiempo han proliferado las columnas de opinión, en parte por aquello que decíamos de que el diario digital permite visualizarlas durante la semana. Las columnas no pierden tan rápido su actualidad y se renuevan, acumulan y cambian con la lógica temporal semanal, como muchos suplementos de noticias.

En cambio, la nota de opinión o de análisis suele ser de frecuencia esporádica y en la que se convoca a un especialista para esa ocasión particular. Muchas veces, se contraponen distintas notas de opinión o de análisis que se solicitan a distintos especialistas, por ejemplo, profesionales: un médico y/o un abogado, y esto se contrapone a las notas de un líder religioso y/o un líder político. Por supuesto que, en casi todos los casos, se trata de notas breves en las que se fundamenta una opinión o análisis sobre una temática específica que suele ser tratada como artículo principal por el diario. 
En los diarios digitales e impresos argentinos, el género periodístico de la crítica suele tratar sobre artes, en el sentido de "espectáculos" (en particular cine, música, danza, artes visuales), sobre productos de los medios (televisión, radio, incluso sobre páginas de internet) y también, desde las columnas de política y economía, ha habido combinaciones posibles con la crítica social y política para describir, argumentar y sobre todo calificar una situación o suceso.

Es frecuente el ejercicio de la crítica socio-política en los artículos publicados por La Nación y LN.COM de Beatriz Sarlo; por ejemplo, cuando se celebró el Bicentenario argentino (Barreiros, 2011).

Este tipo de "crítica socio-cultural" amplia es una suerte de herencia, de supervivencia, de la participación de los intelectuales en los medios; sobre todo en la prolífica tradición del periodismo de crítica sociopolítica argentina -desde Sarmiento en adelante con medios gráficos como El Mosquito, u otros como Caras y Caretas, PBT, Tía Vicenta, Satiricón, Humor, Barcelona. En la figuración mediatizada por Página/12 y P12.com, entre otros medios, de Horacio González podríamos hallar la oposición estilística a la contrafigura de Beatriz Sarlo.

La reseña a diferencia de la crítica suele abordar de manera puntual una obra o producto, que suele ser un film, libro, disco u obra plástica, y hacer con ella una breve descripción que puede tener una calificación final para recomendar, o no, su consumo a los lectores del diario.

\subsection{Estilos ¿enfrentados?}

De los estilos hemos dicho algo inevitable que apunta a su definición como manera de hacer (Steimberg, 1993, 2013), y que da cuenta también de que la clasificación estilística cruza distintos textos, obras que suelen oponerse entre sí en el tiempo sociohistórico y que atraviesa productos, lenguajes, medios, soportes. Así es que se pueden identificar algunos rasgos estilísticos que comparten diarios, como La Nación en nuestro período con La Prensa o El Mundo en el pasado, e incluso en la distancia, las 
coincidencias entre La Nación y Le Monde en la elección de su formato "sábana" para la impresión en papel ${ }^{92}$.

Los estilos, en su condición de clasificaciones sociales, agrupan a productos diversos entre las opciones de su hacer. Por eso, a los textos periodísticos propuestos por el modo estilístico de La Nación se lo suele clasificar como serio, conservador, en oposición al estilo informativo, conciso y popular de Clarín, y al estilo progresista, irónico e interpretativo de Página/12.

En los diarios digitales, estas diferencias no parecen tan claras -muchas veces incluso en los diarios impresos puede haber divergencias de la línea editorial. Esto sucede porque también intervienen estilos de autor, en el caso de las notas firmadas, y estilos de acuerdo a la sección temática. Por ejemplo, la manera de hacer periodismo en deportes no es similar a la manera de hacer política dentro del mismo diario La Nación en su edición impresa, y mucho menos en la edición digital donde las noticias de deportes se "autonomizan" en una página web propia de la temática, llamada Canchallena que tiene su diseño y publicidades propias.

Este estilo que podríamos llamar "de sección", "de suplemento" alude a la famosa frase de Jacobo Timerman "blanco en economía, rojo en cultura" según la cual, el mismo diario podía tener un estilo liberal en la sección económica y un estilo progresista en la de cultura, en referencia y de manera similar al modo de proceder estilístico dominante en la conducta de esos respectivos sectores sociales en un espacio y tiempo histórico determinados ${ }^{93}$.

Steimberg da cuenta en sus "Proposiciones" (1993: 42) que en otras épocas históricas cada género habría portado su estilo en cuanto habría una manera de hacer propia, genérica, a la hora de realizar una obra o producto. También los estilos se conjugan con un estilo de época que puede diferenciarse en el estilo latinoamericano, sudamericano, del Río de La Plata, de la Argentina, de Buenos Aires, etc. En el estilo de época contemporáneo o neobarroco (Calabrese, 1994) predominaría el revival, las citas

\footnotetext{
92 En 2016 La Nación modificó por primera vez en su historia el formato sábana aunque el diseño y diagramación de la edición impresa conservó su similitud visual. Sin embargo, ninguna edición del diario coincide plenamente con otra porque si no sería el mismo, siempre hay leves cambios en la manera de hacer de un medio que suelen ser percibidos a lo largo del tiempo.

${ }^{93}$ Esa caracterización responde más a la década de 1970; en oposición podríamos decir, en la de 1980 se contrapone la figura del hippie a la del yuppie.
} 
al pasado, las mixturas de géneros y estilos (Tassara, 2001; Calinescu, 1991; Lyotard, 1993; Jameson, 1991; Huyssens, 2002).

Más que enfrentados, los estilos existen en sus combinaciones: en sus contaminaciones, en sus permutaciones, y en el reconocimiento que la clasificación social opera sobre los productos, obras, textos, a lo largo del tiempo social e histórico. El enfrentamiento competitivo opera, muchas veces, como reconocimiento de un estilo opuesto a otro anterior, del cual el "nuevo" estilo se ocupa de realizar su "caricatura". 


\section{ANÁLISIS EMPÍRICO. El análisis sociosemiótico: las noticias como clasificaciones mediáticas en la construcción social de sentido}

Hasta aquí hemos trabajado la teoría del signo peirceana y el enfoque sociosemiótico para analizar las noticias que abordan lo religioso con las herramientas conceptuales propuestas a partir de la Teoría de los géneros y los estilos (Steimberg, 1993, 2013).

De acuerdo con la Teoría de los géneros y estilos, nuestra aproximación a las características empíricas de las noticias sobre fenómenos de religión en los medios seleccionados fue realizada a partir de 1) la configuración formal que describimos de los diarios digitales clarín.com, lanacion.com y página12.com, 2) de sus temáticas recurrentes y principales, y 3 ) de sus características enunciativas de estilo, a lo largo del tiempo histórico.

Por supuesto, hemos tenido en cuenta las tradiciones históricas e institucionales así como caracteres propios de la práctica periodística dentro de la descripción de esos rasgos. En este apartado, en cambio, trabajaremos de forma predominante con el material empírico de las noticias sobre religión, ahora reunido en categorías analíticas que enfocan de un modo distinto el material recolectado y observado en el corpus.

Las categorías se desprenden, a su vez, de los resultados de la búsqueda con palabras clave y su organización en dimensiones de análisis. Ambas herramientas adquieren aquí su importancia ya que permiten acceder a la categorización, en parte empírica y en parte analítica, de al menos seis ejes: 1) Religiosidad popular, 2) Educación, familia, sexualidad y reproducción sexual, 3) Diversidad religiosa, 4) relaciones entre Política y religión - Iglesias y Estado, 5) Vaticano, 6) Asistencia Social y Pobreza.

\subsection{Religiosidad Popular}

Las noticias sobre celebraciones, procesiones y festividades religiosas, entre otras manifestaciones de lo que se ha llamado "religiosidad popular", tienen una tradición acompañante que proviene de épocas premediáticas, con la crónica histórica y 
los almanaques (Chartier, 1992; Darnton, 2000; Goody, 1996 [1968], entre otros), y que continúa vigente en la relación temporal de los medios y de la sociedad.

No sólo por conmemorar acontecimientos y fechas en el calendario, sino también por las trayectorias de larga duración que indican momentos de trascendencia de lo sagrado, lo sobrenatural o, al menos, de trascendencia espiritual en la vida cotidiana de vastos sectores populares de la población argentina ${ }^{94}$.

Con el término "religiosidad popular" nos referimos a la dimensión de análisis en la que abordaremos el estudio de las noticias construidas sobre las devociones de sectores sociales considerados como populares en los medios: el culto hacia algunos santos, ciertos lugares sagrados, la devoción por reliquias, imágenes y apariciones milagrosas; las figuras populares que a partir de ciertos ruegos intermediarían con la divinidad, en promesas y pedidos que los creyentes formulan en una religiosidad amplia y difusa, muchas veces no formalizada por las instituciones religiosas o formalizadas mucho tiempo después ${ }^{95}$.

Una definición posible de religiosidad popular:

Religiosidad popular es el conjunto de creencias, gestos modelados (ritos, devociones, prácticas religiosas diversas) y actitudes a través de las cuales los sectores populares de la sociedad expresan sus vivencias de lo sobrenatural y el modo en que se vinculan con lo sagrado. (AA.VV Sociología de la religión, Editorial Docencia, 1996: 188).

De manera perspicaz, este manual de sociología de la religión destaca la ambigüedad de los términos y lo poco productiva que resulta cualquier definición cuando se trata de acontecimientos sobre fenómenos de religiosidad; el carácter cambiante que asumen, en nuestro caso, las reconstrucciones que implican su noticiabilidad en procesos que los ligan a creencias, actitudes y comportamientos insertos en lo social:

\footnotetext{
${ }^{94}$ Remitimos al Atlas de las creencias religiosas en la Argentina (2015, Biblos) dirigido por Fortunato Mallimaci y elaborado por el grupo del Programa Sociedad, Cultura y Religión del Centro de Estudios e Investigaciones Laborales (CEIL) perteneciente a CONICET, en base a datos de la Primera Encuesta sobre Creencias y Actitudes Religiosas en Argentina realizada por el mismo grupo y financiada por Agencia Nacional de Promoción Científica y Tecnológica (ANPCyT) en 2008. Desde una perspectiva etnográfica: Semán, P. (2004), La religiosidad popular, Capital Intelectual, Buenos Aires.

${ }^{95}$ Analizaremos las noticias sobre la beatificación de Ceferino Namuncurá, por ejemplo, sin embargo el Gauchito Gil o la Difunta Correa no son aceptados por la liturgia dogmática del Vaticano, al menos no todavía, aunque como veremos los medios de comunicación estudiados dan cuenta de estas devociones, de sus cambios y actúan en la consideración o la desestimación de tendencias y figuras religiosas.
} 
En el caso de la religiosidad popular latinoamericana podemos señalar que en la actualidad es un fenómeno constatable bajo las formas de la religiosidad popular indígena, del catolicismo popular, de los sincretismos indígenas, de los sincretismos afro-brasileños y de los evangelismos populares: una multiplicidad de realidades que muestran a las claras la complejidad del fenómeno. (AA.VV, 1996: 193).

Las informaciones sobre manifestaciones de religiosidad popular quedan asociadas fuertemente a los anuncios institucionales de la Iglesia Católica argentina, y en particular de su Episcopado. Por ejemplo, la peregrinación a Luján ${ }^{96}$.

En Clarín y clarín.com la religiosidad popular suele presentarse como parte de las festividades y creencias populares que pueden tener relación con el culto católico pero también con cultos y prácticas populares de distintas procedencias; entre otras las indígenas, las mixturas espirituales que asocian, por ejemplo, a Gilda o al Gauchito Gil con los milagros y el cumplimiento de promesas, hasta la peregrinación a santuarios llevando ofrendas.

Si bien el diario CL.COM como enunciador institucional presenta estas informaciones de manera distanciada, las alianzas institucionales y el punto de vista de actores políticos, sociales y religiosos, el enfoque periodístico y sus géneros, por ejemplo la crónica, permiten reconstruir el fenómeno religioso en sus marcos enunciativos (Mainguenau, 1999, 2004; Rodrigo Alsina, 1993) noticiables.

En esos marcos enunciativos mediáticos no faltan los testimonios, las explicaciones de especialistas, ya sean religiosos o científicos sociales, como parte de las representaciones de las voces sociales en juego:

\section{MILES DE PERSONAS LO VENERARON AYER EN DISTINTAS IGLESIAS PORTEÑAS}

San Expedito, el santo de las causas urgentes, cada año reúne a más fieles

Muchos devotos aseguran que el santo es milagroso y "cumple".

Patricio Downes

pdownes@clarin.com

Yo no tenía mucha fe, pero gracias a mamá, le recé a San Expedito y él me sacó de un momento malo y me dio fuerzas para encarar los días", contó a Clarín Carolina Suárez, una porteña de 30 años. Es imposible descubrir siquiera el rastro de horas amargas en el brillo de sus ojos negrísimos y en esa sonrisa radiante, pero ella -como otros fieles reunidos ayer en Balvanera- dijeron que le deben mucho.

\footnotetext{
${ }^{96}$ Es una de las tensiones irresueltas en LN y LN.COM: cuándo la presentación de noticias sobre manifestaciones de religiosidad popular forman parte de las prácticas oficiales y aceptadas, en especial, por el culto católico y cuándo no.
} 
(http://edant.clarin.com/diario/2007/04/20/sociedad/s-03401.htm)

En la noticia anterior, la crónica es firmada por el periodista Patricio Downes y en una columna de análisis el periodista especializado en religión de Clarín y cl.com, Sergio Rubín, explica el crecimiento de la devoción por San Expedito:

\begin{abstract}
Cada vez más devotos
La devoción a San Expedito es un verdadero boom en la Argentina. En apenas una década, el fervor por el santo de las demandas urgentes creció exponencialmente a lo largo y a lo ancho del país sin que aparezca otra explicación del fenómeno que la rápida respuesta a los pedidos que le atribuyen los creyentes que piden su intercesión. Y que se fue conociendo mediante el simple boca a boca.

En rigor, la devoción a San Expedito es muy antigua. Descendientes de italianos -en Italia el santo es muy popular- recuerdan que sus abuelos le rezaban con frecuencia. Sin embargo, en los '60 la devoción en buena medida se perdió a raíz de una tendencia a quitar de los templos algunas imágenes de santos para destacar las de Jesús y María. Pero en torno al 2000, resurgió con singular fuerza. Acaso influyó la distribución de estampitas del santo llegadas de un popular santuario brasileño. Muchos templos colocaron su imagen y lograron una respuesta sorprendente.

El caso más impactante es el de la iglesia porteña de Balvanera que hace tres años rescató de detrás del altar una imagen de San Expedito y la exhibió. Por ese templo, ayer, pasaron decenas de miles de fieles.

Sergio Rubín
\end{abstract}

Entre las noticias que se repiten cada año, las que tratan sobre la peregrinación a Luján están presentes en los tres medios indagados:

\title{
22:35 | MASIVA MUESTRA DE FE
}

Multitudinaria peregrinación a la Basílica de Luján

Miles de jóvenes marchan a pie hacia el santuario de la Virgen. Esta vez, además del fervor religioso hubo reclamos de justicia por Cromañón. La caminata terminará mañana a las 7 con una misa.

(http://edant.clarin.com/diario/2005/10/01/um/m-01015147.htm)

Publicada el 1 de octubre de 2005 en la sección Último Momento, se trata de una actualización nocturna de la información. En esta nota destaca el elemento de la masividad y el componente del pedido de justicia por el caso Cromañón. 
Peregrinación a Luján: para la Policía bonaerense hay 1.300.000 personas 19:45|La cifra es mayor al año pasado y podría ser un récord histórico. La caravana partió al mediodía desde General Paz y Rivadavia. La misa principal será mañana a las 7 . El lema de este año es "Madre, tu mirada renueva nuestra esperanza".

\section{Por: Sergio Rubin}

\section{(http://edant.clarin.com/diario/2009/10/03/um/m-02011479.htm)}

En la comparación de la noticia sobre la peregrinación a Luján de 2005 con la de 2009 podemos observar diferencias de acentuación en la preocupación constante por la asistencia, la cantidad de fieles, la supuesta masividad de 2005 al "récord histórico" de un millón trescientos mil fieles y cinco mil voluntarios en 2009.

Según la nota, la policía bonaerense es la fuente de información. En este sentido, la enunciación de la noticia es construida como si la procesión pudiera significar un índice o un indicador de la creencia religiosa, del número de fieles. Es presentado como una suerte de "censo" en vivo, una demostración de la fe y una reafirmación de la "nación católica", de la vigencia del culto tal como suelen resaltar los líderes religiosos en estas ocasiones.

Además, la noticia es publicada en la sección Sociedad e incluye una referencia acerca de que por primera vez se llevó una imagen de la Virgen a Malvinas; también es destacable que la procesión -como en otros años- parte hacia Luján desde el santuario de San Cayetano, otro lugar de devoción popular en el que se ruega por el pan y el trabajo, y que se conmemora cada 7 de agosto en la ciudad de Buenos Aires.

En 2010 la nota de CL.COM sobre la peregrinación a Luján resalta la presencia de más de un millón de fieles pero el titular de la noticia es conformado por el extracto de una de las declaraciones de Bergoglio con una frase que, según este medio, aludía al momento político:

Fuerte pedido de Bergoglio: "Que no crezca el odio entre nosotros"

MAS DE UN MILLON DE PERSONAS EN LA PEREGRINACION A LUJAN Ante una multitud, el cardenal hizo clara referencia al clima de confrontación. (http://www.clarin.com/sociedad/Fuerte-pedido-Bergoglio-crezcaodio $\left.0 \_347365308 . h t m l\right)$ 
El texto firmado por Sergio Rubín recurre, como otras tantas veces en CL.COM, a una enunciación de relaciones por proximidad que supone el diario con la Iglesia Católica $\operatorname{argentina}^{97}$.

En la alusión que el propio periodista especializado en religión construye en el párrafo citado debajo, el lema de Clarín queda envuelto en las declaraciones de Bergoglio al incluir en la noticia la frase "el toque de atención":

De hecho, Bergoglio aprovechó la principal manifestación de fe de la Argentina -que ayer revalidó cómodamente este título con una masiva asistencia- para formular el toque de atención. Además, aludió a otro motivo de gran inquietud de los obispos: la situación social.

(http://www.clarin.com/sociedad/Fuerte-pedido-Bergoglio-crezcaodio 0 347365308.html)

El párrafo final, en cambio, agregaba en ese momento un componente hacia la futura discusión parlamentaria prevista para el aborto, tanto por sectores que estaban a favor como por los que se oponían. Finalmente esa discusión en torno al aborto no prosperó luego de la sanción de la Ley 26.618, llamada de matrimonio igualitario:

En la plaza, frente a la basílica, sobresalía al amanecer una enorme bandera argentina de 50 metros traída por voluntarios con motivo del Bicentenario. Y una gran pancarta. "Tu mirada denuncia la injusticia del aborto", rezaba.

En el caso de Página/12 desde su comienzo, el 26 de mayo de 1987 (el sitio del diario digital P12.COM funciona desde 2002), es un diario con una declarada posición laicista.

\footnotetext{
${ }^{97}$ En la entrevista que realizamos a Sergio Rubín, el periodista de Clarín especializado en noticias sobre religión, afirmó que Néstor Kirchner "eligió como enemigo a Bergoglio", que esto le convenía al ex mandatario por su tendencia en política a generar el conflicto. Incluso sugería que esa era la posición interpretativa del propio Bergoglio y del Episcopado. Cuando mencionamos las disputas en torno a las políticas de derechos humanos, educación y salud sexual que hubo desde que asumió Néstor Kirchner con el Episcopado argentino, ya desde el tedeum de 2003, Rubin desestimó esos conflictos como el de Baseotto, Aguer, el juicio a Von Wernich y otros. La Ley 26.618 que permitía el casamiento entre personas del mismo sexo, le parecía el momento culmine de esa disputa. Luego de la muerte de Néstor Kirchner y con la asunción de Bergoglio como Papa, según Rubín, la estrategia de Cristina Fernández cambió por conveniencias políticas de ambos actores sociales. Lo interesante fue que rápidamente, respecto al extenso período en que tanto se habló de "gestos tensos y distensiones", los medios del grupo Clarín tuvieron que procesar de forma noticiable los repetidos recibimientos del ya Papa Francisco a Cristina Fernández. Con el cambio de gobierno, tuvo que informar también acerca del destrato del pontífice a Mauricio Macri en sus visitas oficiales.
} 
Sin embargo, la cobertura noticiosa sobre fenómenos de religión no es menor ni está ausente respecto de los otros diarios.

P12 y P12.COM dedican muchas de sus noticias a las informaciones de temáticas religiosas y sus periodistas, algunos de los más destacados como Horacio Verbitsky, prestan especial atención a las relaciones entre política y religión a partir de sus investigaciones periodísticas.

En nuestro período de estudio (2001-2010), Washington Uranga fue uno de los principales periodistas especializados en informaciones sobre religiosidad en P12 y P12.COM, aunque las temáticas religiosas suelen reaparecer en las secciones de sociedad por la atención que tanto el diario impreso como el digital le otorgan a los derechos humanos, sexuales y reproductivos, a las minorías, el aborto, la educación sexual, entre los más relevantes, cuyo tratamiento suele estar a cargo de la periodista Mariana Carbajal, entre otros.

Las fiestas, procesiones y religiosidades populares son abordadas como parte de fenómenos sociales que involucran las creencias y lo popular, y que requieren ser explicados en P12 y P12.COM desde enfoques 'desapasionados':

\footnotetext{
COMENZÓ LA $35^{\circ}$ PEREGRINACIÓN A LUJÁN

Miles de fieles partieron desde el Santuario de San Cayetano, en el barrio porteño de Liniers, en el marco de la 35 Peregrinación Juvenil a Pie a Luján, luego de que el obispo auxiliar de Buenos Aires, Eduardo García, despidió la imagen de la virgen.

PRINCIPAL |Ultimas Noticias [표 |Sábado, 3 de octubre de 2009
}

(http://www.pagina12.com.ar/diario/ultimas/20-132866-2009-10-03.html)

CADA 4 DE AGOSTO SE HARAN ACTIVIDADES EN SU CONMEMORACION

UN DÍA PARA RECORDAR A ANGELELLI EN LAS ESCUELAS

PRINCIPAL IEI país [ [I Jueves, 31 de diciembre de 2009

(http://www.pagina12.com.ar/diario/elpais/1-137862-2009-12-31.html)

Esta noticia sobre la conmemoración de la muerte del obispo Angelelli suma el contenido específico de la memoria sobre los curas del Tercer Mundo, a los motivos 
temáticos del recordatorio y homenaje: su asesinato planificado y ocultado como accidente de ruta por integrantes de la última dictadura militar ${ }^{98}$.

En la siguiente noticia sobre otro aniversario, el del padre Carlos Mugica, el periodista especializado en religión Washington Uranga identifica la "devoción popular" por las figuras de Mugica y Angelelli, en su condición de mártires, al final del primer párrafo del cuerpo principal de la nota:

\section{SOCIEDAD > ANIVERSARIO DE SU ASESINATO \\ 35 años de Mugica \\ Por Washington Uranga}

Sacerdote, militante social, peronista, hombre comprometido con los pobres hasta el punto de renunciar a todo para compartir junto a los marginados su lucha por la dignidad. Carlos Mugica, "cura del Tercer Mundo", sigue siendo, al cumplirse 35 años de su asesinato el 11 de mayo de 1974, un referente de vida para los cristianos identificados con "la opción por los pobres" y para muchos otros militantes de las causas populares. El cura Mugica y el también asesinado obispo Enrique Angelelli son muy probablemente las dos figuras religiosas contemporáneas más evocadas a nivel popular en virtud de su compromiso con la justicia. Existen otros, entre ellos las monjas francesas y los curas palotinos, pero Mugica y Angelelli tienen un espacio ganado en la devoción popular. Y ello se ubica aún más allá de la institución eclesiástica a la que tanto le ha costado reconocer a estos "mártires" y "signos de contradicción" dentro de sus propias filas. (http:/www.pagina12.com.ar/diario/sociedad/3124648-2009-05-10.html, el subrayado es nuestro)

Las imágenes fotográficas que acompañan estas noticias construyen las figuras de sacerdotes que aparecen retratados en situaciones sociales, rodeados por la gente, al aire libre, humildes en sus vestimentas y en su apariencia. Estas noticias tienen también algunos rasgos y componentes del homenaje.

\footnotetext{
98 "El 4 julio de 2014, el Tribunal Oral en lo Criminal Federal de La Rioja consideró delitos de lesa humanidad el homicidio del obispo y el intento de asesinato del ex sacerdote Arturo Pinto y condenó por ellos a los represores Luciano Benjamín Menéndez y Luis Fernando Estrella a prisión perpetua y cárcel común.”,www.elhistoriador.com.ar/articulos/dictadura/el_caso_del_obispo_de_la_rioja_enrique_angelelli .php. Consultado 25/07/2016.
} 
En cambio, la noticia sobre la peregrinación a Luján publicada por P12 y P12.COM se limita a la crónica informativa y cita como fuente a la agencia noticiosa Télam. El diario digital actualizó la información a las 15.25 horas, después del mediodía, en que había comenzado la procesión. Cita algunas declaraciones del obispo, de los creyentes; la nota no está firmada. En la imagen fotográfica la multitud lleva en andas una figura de la Virgen de Luján. La foto es una imagen simbólica típica de esta procesión, que podría haber sido tomada otro año y tal vez provenga de la agencia Télam o de algún sitio de internet.

La noticia de LN.COM sobre la procesión a Luján del mismo año 2009 publicada a las 16.07 horas enfatiza la participación de los jóvenes, a diferencia de la nota de P12 y P12.COM, y resalta en varias oportunidades las palabras del obispo al inicio de la peregrinación:

\section{Miles de jóvenes participan de la peregrinación a pie a Luján \\ La caravana partió pasado el mediodía desde Liniers, luego de que el obispo auxiliar de Buenos Aires, Eduardo García, despidió la imagen de la Virgen; mañana a las 7, Bergoglio celebrará la misa frente a la basílica; vea la fotogalería SÁBADO 03 DE OCTUBRE DE 2009 • 16:07}

(www.lanacion.com.ar/1182016-miles-de-jovenes-participan-de-laperegrinacion-a-pie-a-lujan)

La nota de LN.COM recae en una suerte de círculo argumentativo al destacar la participación de los jóvenes, ya que la peregrinación es organizada por esos mismos jóvenes como indica su nombre "peregrinación juvenil a pie a Luján”, por colegios y parroquias católicas que se identifican con emblemas e insignias.

Una circularidad $^{99}$ similar a la argumentación de la nota de LN.COM es la que utiliza el Episcopado católico argentino para demostrar "la renovación de la fe en la

\footnotetext{
${ }^{99}$ Este rasgo de circularidad en la información periodística es tal vez un modo de funcionamiento propio de la producción de las noticias: al reconstruir los acontecimientos y convertirlos en noticias, los medios retoman la palabra y argumentos de los actores sociales como si fueran "hechos objetivos" y no reparan en la conciencia internalizada que los actores sociales tienen acerca de la presencia e importancia de los medios de comunicación para sus propias actividades. Esto es en parte lo que Verón $(1997,2001)$, entre otros, ha llamado mediatización. De todos modos, la voluntad enunciativa (Steimberg, 1993) de incorporar esas voces y argumentos de manera acrítica es lo que diferencia a este medio; es decir, en otros
} 
juventud" como indica el subtítulo del video que es posible ver en un recuadro de la noticia de CL.COM que citábamos más arriba:

\section{másinformación}

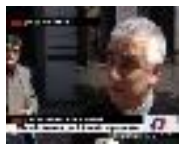

Video | "Esto desmuestra que hay una renovación de la Fe en la juventud", dijo el monseñor Lozano. (TN)

(http://edant.clarin.com/diario/2005/10/01/um/m-01015147.htm)

De este modo, los diarios CL y CL.COM, LN y LN.COM en algunas oportunidades construyen sus noticias "en espejo" respecto de cómo lo hacen las argumentaciones religiosas.

Esto puede deberse a que el enunciador-periodista retoma la palabra de los líderes religiosos y la hace propia en títulos, bajadas y volantas o porque el enunciadordiario ha elegido, entre las opciones argumentativas, plegarse al discurso religioso. Veremos en varias oportunidades esta tensión que, de modo comparativo, no se manifiesta en P12 y P12.com dado su laicismo como posición editorial y estilística al respecto.

En la última nota que citábamos de LN.COM, este medio destacaba la presencia del entonces cardenal Bergoglio en la misa que, decía el texto, recibiría a la peregrinación. La nota presentaba una foto-galería, como una de las posibilidades multimediales del diario digital.

La Nación y lanacion.com tienen una posición ambivalente respecto a la religiosidad popular: informan sobre los fenómenos religiosos tradicionales pero muchas veces las noticias sobre religiosidad popular involucran procesiones o festejos y

casos se contraponen diferentes voces, se desconfía o presenta como una voz parcial: tanto LN.COM como CL.COM suelen retomar la voz de diversas figuras de la Iglesia Católica argentina como autoridad -no así con otros cultos. En cambio, en P12.COM vemos un cuestionamiento permanente del conservadorismo como parte de las dinámicas de estilo y línea editorial en las condiciones de producción de sus noticias. 
otras veces, incluyen a figuras de la cumbia como Gilda o Rodrigo Bueno, e incluso figuras marginales como el Gauchito Gil o San La Muerte que se relacionan con credos de procedencia no legitimada por el dogma católico:

\section{El Gauchito Gil, San La Muerte y una leyenda que aún suma devotos}

En Once hay un santuario privado para pedir por quienes llevan vidas violentas MARTES 06 DE NOVIEMBRE DE 2007

Una pequeña talla en madera o hueso de la figura de un esqueleto incrustada en alguna parte del cuerpo puede proteger a quien la lleva de las balas y las puñaladas. Es la creencia de los devotos de San La Muerte, un culto que crece junto a la devoción al Gauchito Gil.

Según dicen, al policía que debía asesinar al correntino Mamerto Antonio Gil Núñez -acusado de desertar de las fuerzas de seguridad de fines del siglo XIX- le costó mucho trabajo hacerlo. "Porque estaba protegido por San La Muerte; tenía una imagen suya metida en el cuerpo", dicen quienes hacen promesas a uno u otro "santo pagano".

A juzgar por la multiplicación de los "altares" dedicados a ambas figuras populares, el número de sus devotos está en aumento.

(http://www.lanacion.com.ar/959741-el-gauchito-gil-san-la-muerte-y-unaleyenda-que-aun-suma-devotos)

Con letra capital en el primer párrafo del cuerpo de texto, subtítulos celestes e imágenes fotográficas ilustrativas de San La Muerte, la nota firmada por Silvina Premat y publicada en la sección Cultura citaba a especialistas religiosos e investigadores de las ciencias sociales, en un estilo de periodismo interpretativo, y sus opiniones acerca de este fenómeno de religiosidad popular. La noticia es parte de una serie de notas sobre las devociones populares. Para el día siguiente se anunciaba:

Gilda y Rodrigo, con menos visitas - 07.11.2007 - LA NACION www.lanacion.com.ar > Cultura

7 nov. 2007 - Gilda y Rodrigo, con menos visitas | Los devotos les piden milagros, pero son pocos los que hoy se acercan a sus tumbas - LA NACION. ... sus tumbas y santuarios conservan mensajes, pedidos y regalos de fanáticos y devotos que están convencidos de que "Gilda, la única" y "El Potro" hacen milagros. 
Cuando el Vaticano beatificó a alguna de las figuras de culto popular como Ceferino Namuncurá, pareciera que el diario La Nación y LN.COM se hubiera incluido a sí mismo en la enunciación del festejo, en el diminutivo y las comillas, en la sintaxis con el verbo en presente y en primer lugar, a modo de anuncio:

\section{Es beato Ceferino Namuncurá \\ Nacido en Río Negro, el "indiecito" es el primer candidato mapuche a la santidad \\ SÁBADO 07 DE JULIO DE 2007}

(http://www.lanacion.com.ar/923683-es-beato-ceferino-namuncura)

La nota anterior firmada por la corresponsal en Italia, Elisabetta Piqué, tenía un tono casi festivo respecto de la figura de Ceferino, muy distinto al tono de la noticia que Página/12 publicó al respecto:

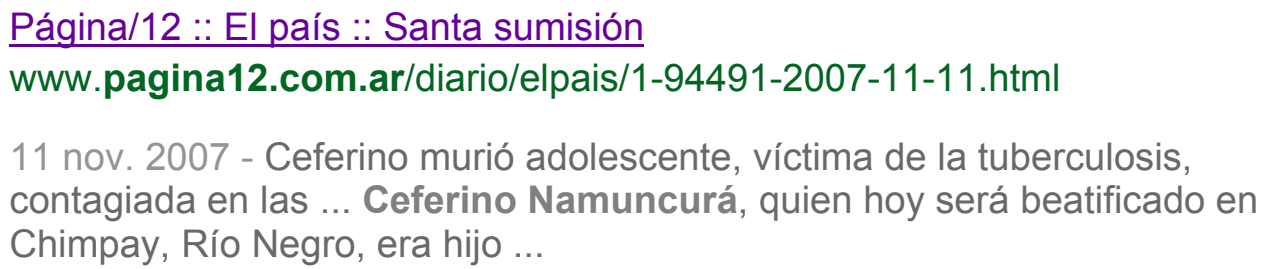

Firmada por Horacio Verbitsky, la nota planteaba una visión continuadora del proyecto secularizador del modernismo acerca de las religiones tradicionales e históricas como opresivas y visibilizaba la inclusión, entre sus santos, del mapuche como parte de las estrategias del Vaticano para reforzar un catolicismo popular y latinoamericano. No reprodujo el apodo de "lirio de la Patagonia" del que hablaba la nota de LN.COM ni su tono festivo.

La presencia de informaciones periodísticas sobre religiosidad popular se encontró en los tres medios de comunicación escrita que observamos: la atención a ceremonias, procesiones, peregrinaciones y festejos populares convocaban la 
mediatización y reclamaban su visibilidad en el espacio público. Los cultos no tradicionales tuvieron una menor visibilidad en el espacio público mediático ${ }^{100}$.

Podemos concluir respecto del tratamiento informativo de esta dimensión de análisis que hubo, al menos, dos posiciones bien distintas en los medios de comunicación escrita que analizamos: la posición de LN.COM y CL.COM que negociaban las significaciones de "lo popular" y lo religioso en cada noticia, con los actores y voces sociales presentes en la construcción que hacen de los acontecimientos, mientras P12.COM mantuvo una distancia crítica frente a lo religioso y, en particular, se opuso al conservadorismo religioso -como vimos en el caso de los aniversarios de los mártires del catolicismo popular, Angelelli o Mugica, pero también en el caso del conservadorismo judío ${ }^{101}$ y a las posiciones conservadoras musulmanas en las noticias sobre las discusiones acerca de laicidad y espacio público en Francia, por ejemplo.

En el período estudiado podemos caracterizar a Clarín y clarín.com como un diario que mantuvo una estrategia de alianzas y negociaciones con el Episcopado católico argentino ${ }^{102}$, alianza que según Sivak (2015) proviene de los últimos tiempos de la dictadura de 1976-1983:

Desde la derrota de Malvinas, Clarín dio visibilidad a los organismos de derechos humanos, ponderó a algunos de sus dirigentes (a los que había ignorado o destratado, como Adolfo Pérez Esquivel), acompañó sus reclamos y en un editorial llegó a exigir que el régimen declinante (al que empezó a llamar régimen) respondiera a los pedidos de las víctimas. (...) En esta nueva orientación de línea, el diario se apoyó en la jerarquización de las noticias, en sus editoriales y también en un actor externo: la Iglesia católica. Desde mediados de 1982, la Iglesia surgió como un punto de referencia central y recurrente en sus páginas, donde se elogiaba sus documentos o se los utilizaba como fuente de legitimación para justificar o exponer las posiciones propias. La Iglesia y Clarín compartían, además, el interés escaso por el examen de sus propias omisiones en los años previos. (Sivak, 2015: 45-46).

\footnotetext{
${ }^{100}$ En el caso del culto evangélico, muchas noticias han sido publicadas sobre los llamados festivales masivos de Luis Palau en la avenida 9 de Julio de Ciudad de Buenos Aires, o de otros líderes evangélicos en estadios de fútbol y en otras ciudades del país. Lo que sucede es que entre los evangélicos no hay devoción por santos ni figuras milagrosas. En este credo, la devoción y veneración es sólo por Jesucristo. ${ }^{101}$ Mientras el rabino progresista Daniel Goldman es un habitual columnista de P12 y P12.COM, los sectores cercanos a Guillermo Borger son identificados como conservadores u ortodoxos; históricamente Marshall Meyer es el referente del judaísmo argentino en la lucha por los derechos humanos que suele destacar P12 Y P12.COM.

${ }^{102}$ El caso que nos llamó la atención y que analizamos en el corpus fue el de Valores Religiosos que como asociación civil es dirigida por líderes de la Iglesia Católica, pese a que se propone como fruto del diálogo interreligioso, y como suplemento es publicado por la empresa periodística privada Clarín y clarín.com; pese al rol público de Valores Religiosos como asociación civil sin fines de lucro. Por otra parte, el trabajo de Martín Sivak (2015) es una investigación periodística basada en fuentes y testimonios para la reconstrucción de la historia de Clarín.
} 
La alianza institucional permitió a CL y CL.COM gestionar el material informativo, ya sea en forma de primicias o exclusivas, y tener una relación privilegiada con el Episcopado católico así como, un poco en espejo, éste la tiene con el Estado argentino. Al mismo tiempo, Clarín y Clarin.com se presentaban a los posibles destinatarioslectores con una enunciación distanciada, supuestamente "neutral", respecto a los intereses y representaciones de los actores políticos de la escena pública argentina.

La Nación y lanacion.com asumían una posición enunciativa cercana al catolicismo al publicar con regularidad noticias sobre acontecimientos religiosos católicos, ya sean aniversarios, ordenaciones, fallecimientos como también procesiones, celebraciones y peregrinaciones, o columnas de opinión firmadas por obispos y cardenales de la Iglesia Católica argentina.

Página/12 y pagina12.com presentaban una posición de defensa de la laicidad dentro de su estilo progresista, satírico e irónico; sin embargo, no dejaron de tratar las temáticas de índole religiosa desde el punto de vista de la crítica, a favor de la ampliación de los derechos sexuales y reproductivos de las mujeres, de las minorías y enmarcados en la defensa de los derechos humanos.

\subsection{Educación, familia, sexualidad y reproducción sexual}

Los principales contenidos específicos de las noticias sobre religión recolectados con la palabra clave educación sexual están relacionados, por un lado, a informaciones periodísticas acerca de la enseñanza escolar de los derechos sexuales y reproductivos de niños y adolescentes; por otro, a noticias sobre el debate y la sanción de leyes en el Congreso de la Nación.

Las notas sobre casos de aborto y aborto no punible, derechos de la mujer e identidad de género, las problemáticas de la infancia y la adolescencia (el llamado bulling y cyberbulling, entre otros) fueron algunos de los contenidos específicos recurrentes.

La Ley de Educación Sexual comenzó a debatirse en 2004 y fue sancionada en 2006, después de muchas discusiones y presiones de sectores conservadores religiosos ligados a las escuelas confesionales (Romero, 2015; Esquivel, 2013; Wainerman, 2008). Clarín.com presentaba notas de esos debates de esta manera: 


\section{Sociedad | SOCIEDAD}

\section{Una norma consensuada}

29/07/09 | El 4 de octubre de 2006 el Senado de la Nación sancionó la ley que establece la obligatoriedad en todas las escuelas del país, estatales y privadas, laicas y religiosas, de impartir un programa de educación sexual integral desde los 5 años. La...

\section{Sociedad | SALUD Y EDUCACION}

\section{Otra dura crítica de la Iglesia a la educación sexual en las escuelas}

29/07/09 | Los contenidos de la educación sexual en las escuelas fueron nuevamente objeto de críticas de parte de la Iglesia Católica. Esta vez, aunque no es la primera, salieron de la boca del polémico arzobispo de La Plata, Héctor Aguer, presidente de la...

Como se observa en las noticias, la aplicación de la Ley en las escuelas y la discusión de su enseñanza siguió siendo muy discutida por sectores religiosos. En particular, por aquellas autoridades religiosas más conservadoras como las representadas por el arzobispo platense Héctor Aguer.

Entre los diferentes tratamientos de las palabras clave, en lanacion.com se destacaban las noticias sobre paternidad y maternidad temprana en relación con la educación sexual, contenido que en clarín.com muchas veces aparecía en suplementos como "Entremujeres", en la revista dominical o en blogs asociados al sitio web.

Además, los contenidos específicos relativos a la educación, la familia, la sexualidad y la reproducción sexual atravesaban diversas noticias y secciones informativas de los medios de comunicación en general. En los diarios impresos y digitales indagados constituyen una temática recurrente que convoca la representación de figuras y narrativas de diversos actores y fenómenos sociales; entre ellos los que cruzan a la religiosidad, en especial, a sus líderes más conservadores que observan cómo la educación es cada vez secularizada en mayor medida ${ }^{103}$.

Desde la discusión y sanción de leyes hasta las tendencias de los "estilos de vida" en las relaciones entre los adolescentes y los padres, la aplicación de normativas

\footnotetext{
${ }^{103}$ Las noticias sobre los sucesivos debates y leyes en Francia por la prohibición de utilizar símbolos religiosos en los espacios públicos, en particular las escuelas, tuvieron lugar en los tres medios indagados.
} 
en espacios sociales públicos como la escuela, el barrio y otras instituciones sociales, las noticias con temáticas de educación sexual analizadas implicaban y cuestionaban los dogmas religiosos, el modelo de la patria potestad, la familia nuclear, entre otros motivos-temáticos recurrentes en las noticias indagadas.

Las secciones Sociedad, Editorial, Entremujeres de CL.COM involucran los contenidos específicos de la salud de la mujer, la familia, la reproducción y la educación sexual de los jóvenes en los ámbitos de la familia y la escuela. Los contenidos específicos suelen ser considerados polémicos en las presentaciones de este diario digital en cuanto a las problemáticas que abordan, tales como el aborto, las enfermedades sexuales, los índices y casos de mortalidad materno-infantil, el abuso sexual, la violencia, entre otros.

Si bien no podemos decir que la presentación enunciativa de estas noticias se haya dado sólo en relación con el mundo de la femineidad, sí fue observable que las construcciones representacionales que hacían estas secciones se opusieran en términos de géneros discursivos al mundo de las secciones presentadas en política, deportes y economía principalmente.

Los títulos, subtítulos y volantas de las notas, los nombres de secciones, resultan parte de las enunciaciones cotidianas en la información periodística de actualidad. CL y CL.COM los construían como tópicos frecuentes entre las noticias, que muchas veces permiten y reclaman la toma de posición del medio, incluso en sintonía con la representación de la opinión en la sección editorial:

\section{Opinión | EDITORIAL}

\section{$\underline{\text { Protección a la salud reproductiva }}$}

21/04/01 | Es una obligación básica de los legisladores el privilegiar el bienestar general por sobre cualquier consideración particular. En materia de salubridad pública ello es una prioridad aún mayor, como lo testimonia el debate en el Congreso Nacional en...

(http://edant.clarin.com/diario/2001/04/21/o-03001.htm) 
Esta editorial reclamaba la sanción y el cumplimiento de la Ley de Salud Sexual que según la nota promueve:

...la procreación responsable, a disminuir la mortalidad materno-infantil, a prevenir embarazos no deseados, a promover la salud sexual de los adolescentes y a garantizar información, orientación y métodos anticonceptivos a toda la población.

No aparece representada la posición de los actores religiosos aunque indicaba que:

La planificación familiar ha sido cuestionada por quienes interpretan el uso de barreras para el embarazo como una postura antinatalista e, incluso, abortista. Sin embargo, la experiencia mundial muestra que no se trata de desalentar la natalidad sino de asegurar que, con información y recursos sanitarios, esta se produzca en las mejores condiciones.

El uso de métodos anticonceptivos y el control ginecológico son usuales en los sectores medios y altos de la población, que cuentan con la información y la atención médicas adecuadas.

Los sectores de menores recursos, en cambio, no tienen el mismo acceso, quedando así en condiciones de desigualdad para planificar el número y momento en que desean tener sus hijos y para preservar su salud. También los adolescentes son un sector vulnerable por la falta de información y educación en materia de sexualidad.

Por eso es central que el Estado garantice acceso gratuito a la información, asesoramiento y asistencia.

En la identificación de posiciones natalistas y antinatalistas el editorial, sin mencionar a los sectores religiosos, sugería e incluso reclamaba una posición paternalista del Estado en cuanto a su intervención en la temática por la salud reproductiva y la supuesta falta de información-educación de los sectores de menores recursos.

\section{Opinión | EDITORIAL}

\section{$\underline{\text { Políticas sociales para prevenir la violencia }}$}


11/10/02 | Un reciente informe de la Organización Mundial de la Salud (OMS) sobre violencia en el mundo, presenta un cuadro inquietante que sólo puede revertirse, como recomienda la misma organización, con medidas preventivas de diverso orden. Según el...

(http://edant.clarin.com/diario/2002/10/12/o-02202.htm)

Las voces religiosas aparecían representadas en una posición crítica sobre la visión secular que propusieron las autoridades gubernamentales y los organismos nacionales e internacionales (ONU, UNICEF, etc.) respecto de la educación y la sexualidad. Sin embargo, era frecuente que sólo fueran citadas las voces de líderes religiosos del Episcopado católico y, en este caso, en conjunto con evangélicos:

\section{Sociedad | EMPIEZA HOY Y HUBO CRITICAS DE LAS IGLESIAS CATOLICA Y EVANGELISTA}

\section{Un congreso en Tucumán reúne a 20 mil mujeres}

09/10/09 | Con unas 20.000 participantes -según el cálculo de sus organizadoras- llegadas de todo el país y también del exterior, comienza hoy aquí el XXIV Encuentro Nacional de Mujeres, que debatirá hasta mañana por la tarde cuestiones candentes de la agenda...

\section{(http://edant.clarin.com/diario/2009/10/10/sociedad/s-02016001.htm)}

En el texto, la noticia mencionaba una sola vez al culto evangélico aunque dijera que fue una medida conjunta de la iglesia evangélica y católica. Sólo aparecía citada la voz del arzobispo católico:

La multitudinaria cita -que por segunda vez tiene a Tucumán como escenario, la primera fue en 1993- motivó el rechazo de las iglesias católica y evangélica locales. Ambas se unieron en la condena a lo que consideran una actividad dirigida a promover el aborto. $\mathrm{Y}$ anoche, en la plaza central de la capital provincial, realizaron en forma conjunta una "Marcha en Defensa de la Vida". 
Las organizadoras consideran que la disyuntiva a favor o en contra del aborto "es mentirosa", ya que lo que ellas defienden, dicen, "es el derecho de la mujer a interrumpir su embarazo en condiciones seguras en un hospital". Y criticaron a la Iglesia por presionar "para que el aborto se mantenga ilegal, no se distribuyan anticonceptivos y no haya educación sexual en las escuelas". El arzobispo Luis Villalba, que ya había defendido la "misión materna" de la mujer y alertado a sus feligreses en contra del encuentro durante la procesión de la Virgen de la Merced, el 24 de setiembre, dispuso que mañana no se oficien misas en los templos del centro de la ciudad "en prevención de posibles disturbios".

Las organizadoras calificaron esa decisión del arzobispo como un intento de hacerlas quedar como "mujeres extrañas y violentas".

Como en muchas noticias que tratan sobre fenómenos de religiosidad, el catolicismo predomina en la visibilidad de la escena pública aunque sostenga alianzas interreligiosas en las que los demás cultos suelen aportar la cantidad significativa de fieles en actos públicos, en especial, los evangélicos pentecostales.

Las autoridades de las religiones tradicionales muchas veces son consultadas por las autoridades gubernamentales. Juan Cruz Esquivel (2013a) narra los debates y tensiones en la elaboración de la Ley de Educación Sexual Integral que finalmente fue sancionada en 2006:

En 2006, se modificó la estrategia política. La incorporación de algunas de las reivindicaciones sostenidas por los sectores más ligados al catolicismo traslucía la relevancia política que detentaba la institución eclesiástica en los imaginarios de los diputados y senadores. La aceptación a que cada escuela procesase los contenidos definidos por el Estado en función de su proyecto educativo institucional, implicaba un recorte relativo de las facultades estatales para fijar los contenidos y, al mismo tiempo, otorgaba cobertura jurídica para que los colegios católicos no se vieran obligados a apartarse de sus principios axiológicos. (Esquivel, 2013a: 6) 
En 2009 seguía la polémica por la implementación de la Ley entre las noticias de CL.COM:

\section{Sociedad | SALUD Y EDUCACION}

Otra dura crítica de la Iglesia a la educación sexual en las escuelas

29/07/09 | Los contenidos de la educación sexual en las escuelas fueron nuevamente objeto de críticas de parte de la Iglesia Católica. Esta vez, aunque no es la primera, salieron de la boca del polémico arzobispo de La Plata, Héctor Aguer, presidente de la...

\section{Sociedad | MONSEÑOR AGUER HABIA DICHO QUE UNA MATERIA TIENE CONTENIDOS NEOMARXISTAS}

\section{Dura respuesta de Oporto a las críticas del obispo de La Plata}

22/06/09 | Es una antigua noticia que proviene de un pensamiento antiguo".

Fue una respuesta sutil y directa de la cartera educativa provincial a las polémicas declaraciones del arzobispo de La Plata, Héctor Aguer, quién este fin de semana volvió a cuestionar...

\section{Sociedad | ASEGURO QUE TIENE CONTENIDOS "NEOMARXISTAS" E IGNORA LA MORAL CRISTIANA}

\section{Polémica: el obispo de la Plata otra vez embistió contra la educación pública}

21/06/09 | El arzobispo de La Plata y principal referente de la comisión episcopal de Educación Católica, monseñor Héctor Aguer, denunció que la enseñanza que reciben los estudiantes en las escuelas públicas está "inficionada de una gran dosis de ideología" y...

\section{SOCIEDAD | NO CEDE LA POLEMICA}

Educación sexual: duro cruce entre un arzobispo y un ministro

01/11/05 I La polémica con la Iglesia por el modo en que se imparte la educación sexual en los colegios reapareció ayer con fuerza. El ministro de Salud, Ginés González García, criticó duramente al arzobispo de La Plata, monseñor Héctor Aguer, quien había... 
La polémica a la que aludía la volanta de la última noticia de CL.COM tenía relación con las declaraciones del vicario militar, Antonio Baseotto. En 2004 se hizo pública una carta que le había enviado al ministro de Salud, Ginés González García, con una cita bíblica que decía que aquellos que escandalizan a los niños debían ser arrojados al mar con una piedra de molino al cuello y en la que, según el religioso, sólo citaba palabras de Jesucristo.

La cita bíblica era explícitamente utilizada para atacar la posición que cuestionaba la penalización del aborto, posición que sostuvo el ministro de Salud en una entrevista publicada en Página/12 y P12.COM.

El gobierno kirchnerista interpretó como una provocación las declaraciones de Baseotto en relación con los crímenes cometidos durante la última dictadura cívicomilitar, conocidos como "vuelos de la muerte" donde arrojaban a los desaparecidos al río o al mar desde los aviones de la Fuerza Aérea. Además, la función de vicario militar de Baseotto, su pasado como obispo de Añatuya y su cercanía con Aguer, hacían que la referencia implícita resultara una provocación evidente hacia la política de derechos humanos del gobierno.

La polémica había comenzado previamente con unas declaraciones de Baseotto sobre la inseguridad en nuestro país cuando zarpaba el buque San Blas rumbo a Haití, a comienzos de 2004; allí se limitó a decir que en la Argentina también había inseguridad, no sólo en Haití.

Alimentada de críticas entre el gobierno kirchnerista y los obispos, la discusión había tenido como protagonistas al sector conservador del Episcopado católico argentino. En 2009, la polémica continuaba respecto a "contenidos neomarxistas", según Aguer, por el reparto de preservativos en las escuelas y en 2010, por el proyecto de ley de ampliación del matrimonio para personas del mismo sexo ${ }^{104}$.

Los distintos sectores conservadores de cada religión suelen establecer alianzas en ciertas coyunturas político-sociales: el conservadorismo que atravesaba al catolicismo, al evangelismo y al judaísmo se unió frente a la Ley 26.618, llamada de matrimonio igualitario, que habilitaba el casamiento entre personas del mismo sexo.

\footnotetext{
${ }^{104}$ Según la entrevista que realizamos con Sergio Rubín, el periodista especializado en religión de CL y CL.COM, las provocaciones habían comenzado desde el gobierno de Néstor Kirchner; al repreguntarle si no consideraba el inicio de las polémicas la realización de los tedeum y lo acontecido en cuanto a la política de derechos humanos con Baseotto, Aguer y otros, Rubín desestimó que hubiera una posición confrontativa desde la conducción del Episcopado en ese entonces (Bergoglio) y que esto era propio de los sectores más conservadores amparados en ese momento por Angelo Sodano, secretario del Vaticano y su sustituto, el cardenal argentino Leonardo Sandri.
} 
Esos sectores religiosos conservadores presionaron a los legisladores, hicieron campañas en medios de comunicación y en espacios públicos con una marcha frente al Congreso de la Nación el día en que comenzaba el debate parlamentario.

\footnotetext{
SOCIEDAD | HOY SE TRATA EL PROYECTO EN EL SENADO

Masiva marcha contra el matrimonio homosexual

14/07/10 | El naranja fue, ayer en la Plaza de los Dos Congresos, el símbolo de la respuesta homogénea frente a la diversidad. El color único contrapuesto a los símbolos multicolores, inclusivos, que contienen los estandartes de la comunidad homosexual y...

SOCIEDAD | ANALISIS
}

\section{La Iglesia puso todo en juego}

14/07/10 | Si se considera que no es fácil en la actualidad convocar gente en las calles, puede concluirse que la manifestación de anoche contra el matrimonio gay frente al Congreso tuvo una importante concurrencia. Si se piensa en la cantidad de personas que...

SOCIEDAD

\section{Fue masiva la movilización de agrupaciones religiosas contra el matrimonio gay}

13/07/10 | Convocados por organizaciones católicas, evangélicas y multirreligiosas, militantes en contra del proyecto que discutirá mañana el Senado y que propone legalizar el matrimonio entre personas del mismo sexo se concentraron esta noche en forma masiva...

SOCIEDAD | MAÑANA ES EL DEBATE EN EL SENADO

\section{Católicos y evangélicos se movilizan contra la boda gay \\ 13/07/10 | Bajo el lema "Los chicos tenemos derecho a una mamá y a un papá", militantes católicos, evangélicos y de otros credos marcharán a partir de las 18.30 al Congreso de la Nación en rechazo al proyecto de ley de matrimonio homosexual que se tratará...}

En LN.COM la educación sexual aparecía como un acontecimiento relacionado con la vida cotidiana. En especial, la de los adolescentes y sus padres, a partir de los debates sobre sexualidad en torno a la escuela y la familia. De este modo, LN.COM se acercaba a una visión humanista y tradicionalista, con acento en la familia, compartida a grandes rasgos con la mirada religiosa cristiana, en particular, próxima a la de la Iglesia Católica:

Tips para hablar sobre sexo con los hijos

...mundo donde el sexo está presente en todos lados. La educación sexual debe ser un capítulo más de los contenidos que los padres les...con respecto al embarazo y a las enfermedades de transmisión sexual. Es conveniente consultar a un médico especialista en estos... 
17.08.2010 | 10:19 | Información general | lanacion.com

(http://www.lanacion.com.ar/1295416-tips-para-hablar-sobre-sexo-con-los-hijos)

$\underline{\text { La influencia de los padres en la relación con el sexo opuesto }}$

...Edipo, ya que de él deriva la posición sexual y la actitud social de la vida adulta. El...en la pubertad, delimitan la elección sexual e imprimen un estilo personal de...partenaire a alguien con su misma conformación sexual", sostiene. Es decir, que se piensa...

10.08.2010 | 10:38 | Información general | lanacion.com

(http://www.lanacion.com.ar/1292979-la-influencia-de-los-padres-en-la-relacion-conel-sexo-opuesto)

\section{"Hay que retener a 168.000 alumnos"}

...ha extendido los derechos que posibilitan que dos personas del mismo sexo contraigan matrimonio y que no hacen a la educación sexual que tiene que estar vinculada con la otra cosa. Si algún chico pregunta sobre la homosexualidad, se le tendrá que contestar...

09.08.2010 $\mid$ Cultura $\mid \underline{\text { Edición impresa }}$

(http://www.lanacion.com.ar/1292736-hay-que-retener-a-168000-alumnos)

Etapa de crisis y de grandes riesgos

...sin el resguardo del preservativo, no sólo los lleva al riesgo del embarazo, sino a adquirir enfermedades de transmisión sexual. Todo lo anterior lleva a que los embarazos en la adolescencia sean -en su amplia mayoría- accidentales, con parejas ocasionales...

\subsubsection{0 | Comunidad | Edición impresa}

(http://www.lanacion.com.ar/1292155-etapa-de-crisis-y-de-grandes-riesgos)

Los desafíos de un padre adolescente

...de lado. Por lo tanto, no tienen con quién hablar sobre el tema de un probable embarazo, saben poco también sobre salud sexual y reproductiva, y carecen de espacios donde llevar sus problemáticas exclusivas de padres adolescentes. En la práctica...

07.08.2010 | Comunidad $\mid \underline{\text { Edición impresa }}$

\section{Ser papá antes de los 18}

...Ministerio de Salud la edad de inicio sexual es de 15 años para las mujeres y...El varón piensa en tener la relación sexual porque es hacer cosas de grandes, pero...muy poco el papel del varón en la salud sexual y reproductiva, y el espacio que se les...

07.08.2010 | Comunidad $\mid \underline{\text { Edición impresa }}$

De eso no se habla...ं̇o sí?

...nacimiento mismo. El campo de la salud sexual y reproductiva tiene algo en común en casi...sexualmente a esa edad. La edad de iniciación sexual no ha cambiado demasiado y es mayormente...contagio de infecciones de transmisiónsexual ha aumentado en algunas poblaciones mayores...

04.08.2010 | 12:59 | Ciencia/Salud | lanacion.com 
Los datos y estadísticas sobre reproducción sexual no fueron materia informativa privilegiada en el enfoque de estas noticias:

\section{$\underline{\text { La Legislatura tratará una ley que beneficiará a los homosexuales }}$}

...términos generales: Se entiende por unión civil a la conformada por dos personas con independencia de su sexo u orientación sexual. Que hayan convivido (...) por un período mínimo de dos años, salvo que entre los integrantes haya descendencia en común...

\subsubsection{2 | Información general $\mid$ Edición impresa}

(http://www.lanacion.com.ar/457372-la-legislatura-tratara-una-ley-que-beneficiara-alos-homosexuales)

En el final de la nota:

\section{Opina la Iglesia Católica}

El jesuita Enrique Fabbri, especialista en familia, se declaró absolutamente en contra del proyecto: "El poder civil está obligado a trabajar por el bien común y no puede equiparar una pareja heterosexual, que da la garantía del amor social y de educación de los hijos, en una estructura homosexual".

Fabbri finalizó diciendo que "habría que cuestionar si el Estado puede legislar dando la impresión de que es lo mismo cualquier unión entre seres humanos".

\section{LA NACION \\ Información general}

En 2010 la posición de LN.COM en cuanto al debate y sanción de la Ley 26.618, conocida como de matrimonio igualitario, tuvo noticias con títulos como el siguiente ${ }^{105}$ :

\section{Mamá-papá, mamá-mamá, papá-papá}

${ }^{105}$ Estas notas formaron parte de un corpus en el análisis de los comentarios de lectores de LN.com: Diéguez, F. (2015), "El conservadorismo religioso en los comentarios de lectores del diario digital lanacion.com", en: Esquivel, Juan Cruz y Vaggione, Juan Marco (dirección). Permeabilidades Activas. Religión, Politica y Sexualidad en la Argentina democrática. Buenos Aires, Editorial Biblos. 
...ambos padres influir en la orientación sexual de sus hijos? Si la especie humana deja...la misma no depende de su orientación sexual". Por su parte, un flamante informe...para la psique infantil. "La identidad sexual se construye en relación con la cultura...

18.07.2010 | Enfoques $\mid$ Edición impresa

$\underline{\text { Postales de una sesión que quedará en la historia }}$

...homosexual. Negre de Alonso, por ejemplo, se mostró preocupada por las consecuencias que tendría el proyecto en educación sexual. José Mayans, uno de los pocos kirchneristas que votó en contra, argumentó que considera al matrimonio entre un hombre y...

15.07.2010 | 10:17 | Información general | lanacion.com

Una áspera sesión en el Senado

...En un momento, leyó un fragmento de un Manual de Educación sexual y, mientras mostraba dibujos, expresó: "Les vamos a tener que enseñar...se cruzó con Negre de Alonso por el tema de la educación sexual. La senadora pidió la palabra para declarar que fue discriminada...

15.07.2010 | 02:42 | Información general | lanacion.com

\section{No alcanza con tolerar}

...Para la comunidad científica, la homosexualidad no es una enfermedad y, si bien la religión puede colocar la conducta sexual de las personas en el centro de sus sistemas éticos, el Derecho, no. La homosexualidad, entonces, no es un problema para...

08.07.2010 | Opinión | Edición impresa

Las secciones donde LN.com publicaba las noticias sobre educación sexual solían ser Información general, Comunidad, Ciencia/Salud. La toma de posición se visibilizaba en las notas de opinión firmadas y fue poco frecuente que la temática de educación sexual apareciera en el editorial. En cambio, la temática del matrimonio igualitario ameritó editoriales bajo tono imperativo:

\section{Matrimonio homosexual: ante una enorme responsabilidad}

Al votar un proyecto tan cuestionado, los senadores deberían seguir el dictado de sus conciencias y no las órdenes partidarias

\section{LUNES 12 DE JULIO DE 2010}

Con la perseverancia y el apasionamiento que suelen reservarse para la defensa de las grandes causas, el Gobierno ha salido a intentar provocar otra profunda división en la sociedad argentina.

Ha resuelto, en efecto, que, como si se hubiera tratado de alcanzar al fin la victoria por la cual el peronismo hubiera luchado toda la vida, la Argentina debe modificar las raíces del régimen matrimonial. Es decir, echar abajo, como consecuencia de la aceptación legal del matrimonio entre personas de igual sexo, una institución que tiene siglos de existencia.

Que varios países, representativos del cuatro por ciento de la población mundial, lo hayan hecho no autoriza a tomar ese camino. No ha sido la religión, sino la naturaleza la que 
introdujo en el sistema de valores de innumerables civilizaciones la idea de que el matrimonio legislado por la ley ha de ser entre un hombre y una mujer. (...)

Ningún desinterés entre los tantos manifestados por este gobierno en relación con las instituciones de la Nación ha ido más lejos, por haber ido más al fondo, que el haberse propuesto sacudir la institución madre, básica entre todas, de una sociedad: la familia.

La discriminación consiste en tratar de diferente manera dos situaciones iguales, no dos situaciones distintas. La perpetuación de la especie está en la base del matrimonio y dos personas del mismo sexo no pueden corresponder a ese requisito por razones antropológicas de toda evidencia. El Estado, como se ha dicho, no regula la vida afectiva de las personas; regula una institución que cumple una función social. (...)

(http://www.lanacion.com.ar/1283755-matrimonio-homosexual-ante-una-enormeresponsabilidad)

El editorial de LN y LN.com postulaba, en primer lugar, una demanda a los legisladores: que no votaran por obediencia sino por conciencia, dado que descontaba el tratamiento de la ley. En segundo lugar, argumentaba de un modo similar a las posiciones del conservadorismo religioso acerca de la "naturaleza" del matrimonio, de la voluntad de disputa del kirchnerismo y su enfrentamiento con "la religión" que en realidad era sólo con un sector de la Iglesia Católica argentina. Los argumentos que el editorial esgrimía apelaban más a las costumbres, la tradición y a la conservación de la "familia" heteronormativa.

En definitiva, la acción performativa del editorial buscaba reforzar el compromiso de aquellos senadores que iban a votar en contra de la llamada ley de matrimonio igualitario para que sus votos no cambiaran de signo. Fue una estrategia discursiva que LN y LN.com repitieron en 2010:

\title{
Legislar antes de que llegue el aborto
}

\author{
Cinco diputados nacionales de la oposición proponen crear herramientas para proteger a la \\ mujer y para garantizar al niño el derecho inalienable a la vida \\ SEGUIR \\ Mariano De Vedia \\ LA NACION
}

LUNES 06 DE DICIEMBRE DE 2010

Mujer embarazada y niño por nacer. ¿Por qué enfrentarlos, al extremo de promover la falsa opción entre los derechos de una y de otro y no ampararlos en forma conjunta? Unos 15 diputados de distintos bloques coinciden en que lo principal es anticiparse y no llegar al traumático instante del aborto. 
Por eso, presentaron la semana última un proyecto para crear herramientas que protejan a la mujer y garanticen al niño el derecho inalienable de la vida.

Como fórmula novedosa, la iniciativa contempla que cuando el embarazo surja de una violación la mujer recibirá una asistencia económica durante todo el período de gestación, que se abonará hasta los 18 años si la mujer decide asumir la crianza y educación del niño, en concepto de asignación universal por hijo por nacer.

Propone, además, el funcionamiento de centros de asistencia permanente en los hospitales públicos, especialmente para las adolescentes y mujeres de pocos recursos, y la posibilidad de acelerar los plazos de adopción, para los casos en que la madre renuncie a criar al bebe.

(http://www.lanacion.com.ar/1331083-legislar-antes-de-que-llegue-el-aborto)

Entre los autores del proyecto se encontraba la evangelista Cinthya Hotton y la principal organización que lo impulsaba era la Red Federal de Familias, que reúne varias organizaciones no gubernamentales llamadas "pro-vida" (Esquivel y Vaggione, 2015), donde fue frecuente la alianza interreligiosa de sectores conservadores de diversas orientaciones políticas.

Observamos que en LN y LN.COM no se postulaba la urgencia informativa por dar conocer las noticias, por informar a los posibles lectores, como planteaba CL y CL.com, ni de los juegos de lenguaje, irónicos, satíricos, de P12 y P12.com. En LN y LN.com de lo que se trataba era de adelantarse a las problemáticas, una suerte de “prevención" expresada en las dos noticias anteriores en la preposición 'ante' y en el indicador temporal 'antes': ante y antes de tal problemática es mejor hacer X, pareciera ser el enunciado del medio en estas noticias.

De este modo, decíamos cumple su acción performativa: La Nación tal vez ya no sea "una tribuna de doctrina", en línea con su lema creado por Mitre, pero el pedagogismo todavía pareciera ser un componente enunciativo importante en este medio. En este sentido hemos dicho que en LN y LN.com practican un periodismo interpretativo: la interpretación valorativa de los "hechos" sociales.

El seguimiento de la aprobación del aborto en España y los debates legislativos en el Congreso argentino sobre el aborto motivaron varias noticias en LN.com: 
Por Adrián Sack Especial para lanacion.com MADRID - La ley de "aborto libre" ya es una realidad que lamentan y festejan con similar intensidad los sectores conservadores y progresistas anticlericales...

\title{
24.02.2010 | 03:31 | Exterior | lanacion.com
}

\section{$\underline{\text { Vuelve al Congreso el debate por el aborto }}$}

...proyecto de ley que reglamenta los casos de aborto no punible avanza en el Congreso Nacional...entrada para la despenalización total del aborto en el país, reclamada por Ginés González...La norma autoriza la realización del abortocuando peligra la salud o la vida de la...

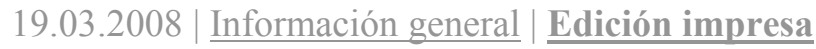

A diferencia de CL y CL.com que consideraban todas las temáticas vinculadas a la educación sexual como temas de debate, en LN y LN.com sus noticias plantearon el aborto como uno de los temas de mayor polémica en la Argentina. En cambio, P12 y P12.com asumían en sus noticias la representación a favor de las posiciones sociales de militancia activa respecto de los derechos sexuales y reproductivos de las mujeres, de las minorías, de la igualdad entre las diversas identidades de género:

\author{
UN DEBATE CONTRA LOS MIEDOS \\ Si bien cuestionan al presidente de la comisión por convocar a la audiencia cuando el año parlamentario expira \\ cuatro diputadas de distintos bloques destacan la importancia de la jornada pública de hoy. El debate en 2011 \\ obligará a definiciones de los candidatos. \\ PRINCIPAL |Sociedad |ㅛㅛ| |Martes, 30 de noviembre de 2010
}

\section{LAS MUERTES QUE SE PUEDEN EVITAR}

\author{
> Por Mariana Romero
}

PRINCIPAL ISociedad |Martes, 30 de noviembre de 2010

En una entrevista a Nora Cortiñas, la defensa de los derechos de las mujeres convergía en el marco de la defensa de los derechos humanos, por la falta de acciones del Estado frente al problema del aborto y las muertes maternas:

\section{CORTIÑAS: "TODOS PERMITIERON QUE TORTURARAN A LAS EMBARAZADAS PERO AHORA SE OPONEN AL ABORTO" \\ Nora Cortiñas, una de las fundadoras de Madres de Plaza de Mayo, acusó al arzobispo de Buenos Aires, Jorge Bergoglio, de "entregar" a los sacerdotes jesuitas Orlando Yorio y Francisco Jalics, quienes todavía se encuentran desaparecidos, y responsabilizó a la "jerarquía católica y política" por despreciar la vida. \\ PRINCIPAL |UItimas Noticias [}


La posición de P12 y P12.com también era observable en la selección de las declaraciones y citas en los títulos:

EN UN MULTITUDINARIO ACTO EN LA CASA DE GOBIERNO, CRISTINA KIRCHNER PROMULGO LA LEY DE MATRIMONIO PARA PERSONAS DEL MISMO SEXO

\section{"AHORA SOMOS UNA SOCIEDAD UN POCO MÁS IGUALITARIA" , Por Soledad Vallejos \\ Hubo emoción y euforia. Hubo aplausos y ovaciones. Ante cientos de militantes de la diversidad sexual y un variado arco de invitados, la Presidenta puso su firma al matrimonio igualitario. "Hemos promulgado una construcción social transversal", dijo. \\ PRINCIPAL |EI país 표 |Jueves, 22 de julio de 2010}

CARCEROLAZO CONTRA LA CORTE SUPREMA POR LA PILDORA

\section{“MI CUERPO ES MíO, MíO, MíO”}

PRINCIPAL | Sociedad |subnota |Viernes, 8 de marzo de 2002

Mientras CL y CL.com reclamaban una mayor intervención del Estado en las políticas de salud reproductiva, para P12 y P12.com el Estado debía asegurar el derecho al aborto. En LN y LN.com, en cambio, apareció manifestada la preocupación por la legalización del aborto.

A grandes rasgos podemos caracterizar cada medio frente a las temáticas de educación, familia, sexualidad y reproducción sexual a partir de la caracterización general de una posición militante (P12 y P12.com), una posición “conservadora” (LN y LN.com) y una posición que reclamaría la intervención estatal (CL y CL.com), en particular, respecto a la reproducción y salud sexual que involucran las problemáticas del aborto, de la adopción de niños, entre otras.

\subsection{Diversidad religiosa}

Si las religiones no pueden reducirse a los credos tradicionales de salvación y éstos tampoco al dogma institucional y al culto religioso porque involucran a la cultura, a la historia étnica y política de cada civilización, entonces el concepto de diversidad religiosa pone en discusión lo que entendemos por religión en nuestras sociedades. 
Por eso hemos utilizado con frecuencia el término fenómenos de religiosidad y mencionamos las espiritualidades como parte del paisaje religioso contemporáneo reconstruido por y en los medios.

Entre otras cuestiones, la diversidad religiosa confronta con un doble mito presente en la sociedad argentina contemporánea: el de la 'nación católica', por una parte, y el de la 'república laica', por otra. Para Zanatta (1996) la nación Argentina se constituyó en torno de una mitológica herencia católica que provendría de tiempos de la Colonia española; para Mallimaci (2015), la república Argentina no fracturó esa herencia católica y el laicismo formó parte de un mito de la generación de 1880:

Para comprender el largo plazo hay un mito a deconstruir en Argentina: el creer que en sus orígenes históricos hubo una sólida y única República laica, democrática y liberal, y que en las décadas de 1920 y 1930 fue suplantada por otra sólida y única Nación católica, orgánica y nacionalista. Debemos tomar distancia del mito de la Argentina laica. (Mallimaci, 2015: 25).

Ambas líneas de pensamiento concuerdan en considerar que estas posiciones antagónicas se convirtieron en mitos de origen (Barthes, 2003) antes que en una característica del "ser nacional", esa otra ficción construida por los mismos moldes míticos.

En el caso de los medios de comunicación escrita (en particular los que analizamos: Clarín y CL.com, La Nación y LN.com, Página/12 y p12.com) han formado sus estilos periodísticos en una relación estrecha con estas concepciones míticas de la 'nación católica' y la 'república laica' que forman parte de la doxa y del sentido común que circula en el espacio público mediático, con variaciones propias de las épocas.

El pluralismo en cuanto a fenómenos de religiosidad demuestra que el proclamado monopolio de la religión católica nunca fue tal, ni siquiera en épocas de la Colonia española:

Hay entonces un mito de la colonia católica, al que podemos sumar otros que ha acuñado la historiografía -sobre todo, pero no sólo, la declaradamente confesional- y que se relacionan con la idea del monopolio católico. Como el que afirma que en el siglo XIX los sectores subalternos nativos eran más devotos que las elites, imbuidas de ideas "foráneas" y en consecuencia ilegítimas (se piensa en especial, desde luego, en la 
cosmopolita elite cultural porteña). Los mitos también forman parte de la realidad, como bien sabemos y como bien ilustra, en relación con nuestro problema, la historia de la Iglesia. Para buena parte de la producción de inspiración confesional es indiscutible la identificación de la nación con la fe católica, como lo es también para los obispos y en general para el clero. Hay versiones de izquierda y de derecha, populistas y elitistas. (Di Stéfano, 2013: 9).

Desde este punto de vista parece inevitable la existencia de una diversidad de creencias y prácticas religiosas que exceden los marcos regulatorios de las grandes religiones históricas monoteístas. Incluso hacia el interior del propio cristianismo y también del catolicismo existe diversidad entre sus sectores conservadores, moderados y populares, entre los movimientos carismáticos y políticos de diversa orientación ideológica (Esquivel, 2004; Giménez Beliveau, 2008).

Según la Primera Encuesta sobre Creencias Religiosas (2008) elaborada por el Programa Sociedad, Cultura y Religión del instituto CEIL, perteneciente al CONICET, la diversidad del campo religioso en la Argentina reúne un 76,5\% que se define católico, un $9 \%$ que se declara evangélico y un $11,3 \%$ que se considera indiferente, es decir, ateo, agnóstico o sin religión.

En este sentido, es creciente el pluralismo y la diversidad del creer respecto a lo que declaran las autoridades religiosas, en especial las católicas. También es interesante que dentro de la diversidad evangélica, este grupo está conformado en su mayor parte por los Pentecostales (7,6\%) pero también reúne a Testigos de Jehová $(1,2 \%)$, Mormones $(0,9 \%)$, y en menor medida a Baptistas, Luteranos, Adventistas y creyentes en la Iglesia Universal del Reino de Dios.

Con todo y pese a los datos, decíamos, que mucho menos puede pensarse que otras manifestaciones de la espiritualidad contemporánea, que suelen ser rotuladas bajo el concepto de diversidad, puedan reducirse a un culto o a una religión. Hay creencias que exceden lo institucional y se presentan como filosofías de vida o terapéuticas existenciales, entre otras posibilidades:

Los estudios etnográficos recientes revelaron cómo estas expresiones propias de nuevas sacralizaciones populares o prácticas de sanación y auto-transformación, junto a otras, presentan una característica en común: su rechazo a adoptar la categoría "religión" como representativa de sus valores, ideales y acciones. (...) Las autoadscripciones podrán expresarse en términos emocionales ("es una pasión", "es un sentimiento"), o 
bien "estilos de vida" o "filosofías", pero otra categoría se insertó progresivamente para definir esta y muchas otras valoraciones y/o pertenencias: la "espiritualidad". (Ceriani Cernadas, 2013: 34).

Más allá de las estrategias de presentación de las espiritualidades, la diversidad religiosa también se encuentra en los límites difusos de las prácticas y creencias del judaísmo, el islam y el cristianismo, interrelacionadas con modos de vida cada vez más globalizados en las sociedades contemporáneas (Mallimaci, 1996; Bokser Liwerant, 2008). Como señala Marc Abélès en su antropología de la globalización:

\footnotetext{
Se trata más bien de mostrar que la dimensión cultural está en el centro del proceso, por el lugar que toma hoy en día el imaginario de la globalización y sus consecuencias inesperadas: mientras que durante mucho tiempo los teóricos de la modernización y de las críticas a la cultura de masas planteaban como ineluctable una secularización del mundo, cada vez más sometido a la racionalidad científica, nos percatamos de que, a la inversa, el desarrollo espectacular de los medios de comunicación hizo posibles nuevos e imprevisibles despliegues del imaginario colectivo. Los movimientos religiosos actuales atestiguan en particular esta búsqueda de nuevas trascendencias. (el destacado es nuestro, Abélès, 2012: 62).
}

Podríamos agregar que las creencias, prácticas y representaciones se imbrican en el acontecer y devenir de las sociedades globalizadas en las que también aparecen manifestaciones espirituales del budismo, la New Age, u otras formas de espiritualidad en el sentido amplio (Ceriani Cernadas, 2013; Viotti, 2011; Viotti y Funes, 2015).

En los medios seleccionados, la diversidad religiosa se compone de noticias sobre cultos no tradicionales, por una parte, y de noticias sobre prácticas espirituales de una variedad amplia, por otra. La estigmatización de minorías religiosas calificadas como "sectas" (Frigerio, 1993) es habitual todavía en las páginas de papel y en sitios web de los diarios digitales.

Pese al crecimiento de la diversidad y el interés por los nuevos movimientos religiosos, el pluralismo en el campo religioso argentino no llega a constituir la aceptación de cultos no tradicionales. Además, entre el culto católico y los demás cultos continúa el tratamiento institucional diferenciado y legitimado por el Estado. Según Juan Cruz Esquivel: 
...desde los albores de la evangelización, la Iglesia intentó asimilar la cosmovisión del ser cristiano con el ser nacional... desde antaño, el comportamiento histórico del catolicismo, lejos de recluirse en el ámbito de la sacristía, se extendió al espacio político y social, en base a la legitimidad que la idea de 'credo nacional' o 'doctrina de Estado' le confería (Amestoy, 1991)." (...) "La Carta Magna (de la Constitución Nacional de 1853) contempló la libertad de cultos aunque no la igualdad de los mismos. Al catolicismo se le reservó un lugar privilegiado, pese a que no se lo estableció explícitamente como 'religión oficial'.", (Esquivel, 2008: 173).

Desde la óptica del análisis del movimiento evangélico, Joaquín Algranti explica que:

La dificultad para producir la separación entre ambos agentes descansa en parte en el modelo del Patronato Regio, que habilita al poder político a intervenir directamente en los asuntos pastorales, a la vez que ofrece un lugar de privilegio a la Iglesia ante los recursos materiales y simbólicos del aparato estatal y la clase gobernante (Di Stefano y Zanatta, 2000). El Patronato no obedece a un contrato explícito, sino a una forma de relación, una mentalidad de los mismos eclesiásticos (Auza, 1996), que funciona como un instrumento de gobernabilidad, en donde la religión y la política se superponen constantemente." (Algranti, 2010: 34-35).

En el modelo del Patronato, las influencias y presiones irían tanto desde la religión a la política como de la política a la religión. Muchas veces es la clase política la que solicita distinto tipo de intervenciones al Episcopado argentino, tal como pudimos observar en las noticias sobre la Mesa del Diálogo argentino de 2001. Estas superposiciones no ayudan a transformar la diversidad de las creencias religiosas existentes en la sociedad argentina, en una pluralidad que coexista sin la sombra de la hegemonía católica:

El vínculo entre religión y política, que durante el siglo XX va a adoptar la forma de Iglesia y Estado, no solo sobrevive al impacto de dos fuerzas modernizadoras, como son la constitución del Estado nacional y el desarrollo del capitalismo, sino que también se logra estabilizar posteriormente una dinámica de relaciones por momentos de superposición, por momentos de competencia y rivalidad, en donde el catolicismo, como plantea Fortunato Mallimaci (1992), aparece con un proyecto propio de modernidad que rivaliza con la alternativa liberal y socialista. (Algranti, 2010: 36-37).

La lógica mediática continúa en este aspecto la del Estado al diferenciar al culto católico de los demás cultos. Incluso en un diario como Página/12, y su edición digital P12.COM, que en su posición editorial comparten la preocupación de que haya un mayor pluralismo religioso en nuestro país. 
Sin embargo, sus noticias no pueden dejar de tematizar las relaciones entre política y religión, la presencia pública de la Iglesia Católica argentina y de la fe evangélica. Tratadas de manera diferencial, respecto a las demás prácticas y creencias religiosas, esas informaciones suelen ser clasificadas en las secciones de política y sociedad.

Un ejemplo de P12.com es la nota publicada en la sección Psicología, de la psicoanalista francesa Elisabeth Roudinesco, donde plantea una visión modernista acerca de las sectas e incluso sobre el poder evangélico brasileño y sus relaciones con la deontología psicoanalítica:

\section{Ese otro terror}

Un análisis de las sectas, "cuyo espectro merodea en el futuro de las sociedades democráticas" y que, "a fuerza de borrar la separación entre sí y el otro, lleva hasta sus últimas e insoportables consecuencias el sacrificio del cuerpo, la anulación de la conciencia, la destrucción de la identidad".

\section{PRINCIPAL |Psicología |프 |Jueves, 12 de mayo de 2005}

La estigmatización a la que aludía Frigerio (1993) tiene relación con la clasificación en la sección policiales de las informaciones sobre algunos cultos como el umbanda, algunos grupos evangélicos y otros calificados de sectas.

En cambio, en el caso de delitos relacionados con líderes de la Iglesia Católica como sucedió en el caso Grassi, con acusaciones de pedofilia en la Fundación Felices los Niños- esas informaciones eran clasificadas por los medios en las secciones de política, información general o sociedad. Algunos ejemplos recurrentes de clarin.com (en el caso de la primera noticia, publicada dos días consecutivos):

\section{Policiales | Fue detenido en una isla de tigre}

\section{Cae un pai umbanda acusado de descuartizar a dos mujeres}


07/05/10 | Un pai umbanda fue detenido en el partido de Tigre, acusado de asesinar y descuartizar a dos mujeres (su esposa y una ex pareja), cuyos cuerpos desmembrados fueron hallados en distintos puntos de la zona norte del conurbano entre 2006 y 2008. El...

\section{Policiales}

Tigre: detienen a un pai umbanda acusado de asesinar a dos mujeres

06/05/10 | Un hombre de 48 años, practicante de la religión umbanda, fue detenido esta madrugada en el partido bonaerense de Tigre. Lo acusan de haber asesinado a su esposa, a su ex concubina y de haber abusado sexualmente de una nena de 9 años. El detenido...

\section{Policiales | EN SU TEMPLO DE MORENO}

\section{Detienen a un pai umbanda que prostituía a sus fieles}

02/04/09 | Las mujeres llegaban al templo desesperadas por problemas familiares o económicos. El pai las consolaba, les decía que tenían su protección y les ofrecía ayuda. Pero esa ayuda no era desinteresada, después de un tiempo, cuando había logrado su...

\section{Sociedad | INVESTIGACION ESPECIAL}

Todo por amor: pagan hasta 3.000 pesos por recuperar o mantener a una pareja

27/01/07 | Qué te pasa?, pregunta el Rey del Amor mientras saluda con la mano regordeta, rasposa - como su voz- y con un anillo de oro en el anular. En la mesa queda una flaca vela blanca apagada. En persona y sin el glamour de las fotos trucadas que lo...

\section{Policiales | EL CRIMEN OCURRIO EN COLEGIALES EN 2002}

\section{$\underline{\text { Perpetua para un pai umbanda que descuartizó a una mujer }}$}

09/05/05 | Reclusión perpetua. Esa fue la pena que recibió ayer un "pai umbanda" que asesinó y descuartizó a una investigadora del Conicet, en 
diciembre de 2002. La última jornada del juicio tuvo una particularidad: se desarrolló en el Hospital Muñiz y los...

Policiales | LOS TESTIGOS LO INCRIMINARON Y ESTA SEMANA SON LOS ALEGATOS

Juicio oral a un pai umbanda por descuartizar viva a una mujer

20/02/05 | Diciembre de 2002. Un hallazgo macabro conmocionó a los vecinos de Colegiales: una mujer fue descuartizada en su departamento. Un pai umbanda, detenido por el crimen, está siendo juzgado por el Tribunal Oral 21, acusado de "homicidio calificado por...

P12 y P12.COM muchas veces reprodujeron el prejuicio que señala Fortunato Mallimaci (2015): como la Iglesia Católica argentina ha tenido tanto peso en la historia argentina entonces se presupone que es importante seguir de cerca su accionar y estrategias. Es, en términos generales, la visión enunciativa que plantean las notas de Horacio Verbitsky y sus libros sobre la historia de la Iglesia Católica argentina, en particular Cristo Vence (Verbitsky, 2007) ${ }^{106}$.

En LN y LN.COM las noticias sobre diversidad religiosa ocupan un amplio espectro que va desde las relaciones del catolicismo con los demás cultos, al exorcismo y la diversidad religiosa como parte de la diversidad cultural, entre otros:

Iglesia y sectas en América

Jorge Rouillon

LA NACION

LUNES 22 DE ENERO DE 2007

Anteayer, en Roma, Benedicto XVI subrayó la "necesidad urgente de una nueva evangelización" en América latina, al recibir a los 40 miembros de la Comisión Pontificia para América Latina; entre ellos, el cardenal Jorge Bergoglio, arzobispo de Buenos Aires, y monseñor Héctor Aguer, arzobispo de La Plata. (http://www.lanacion.com.ar/877254-iglesia-y-sectas-en-america)

\footnotetext{
${ }^{106}$ Es una crítica, posible, desde la lógica del análisis social en el debate sobre la secularización; desde la lógica periodística el peso histórico que ha tenido la Iglesia Católica en relación con el accionar estatal es algo comprobable, como plantea Verbitsky, en los dos siglos de existencia de la República Argentina e incluso, desde la época colonial.
} 
"Los grupos pentecostales son el nuevo desafío para la Iglesia"

El cardenal Kasper dijo que la relación con los cultos cristianos está estancada VIERNES 21 DE SEPTIEMBRE DE 2007

La preocupación de los obispos latinoamericanos por la seducción que ejercen sobre los católicos las nuevas sectas religiosas y grupos pentecostales, carismáticos y evangélicos -expresada ante el Papa y los medios de comunicación en las últimas dos décadas- fue escuchada por el Vaticano. (http://www.lanacion.com.ar/945942-los-grupos-pentecostales-son-el-nuevodesafio-para-la-iglesia),

El exorcista de la calle 6

Jorge Fernández Díaz

LA NACION

\section{SÁBADO 18 DE JULIO DE 2009}

A Miguel se le aparecía en sueños una monjita que le señalaba el rostro de un hombre. En su desesperación, Miguel soñaba que esa mujer piadosa y consagrada le decía, sin palabras, "este hombre puede salvarte del averno". Miguel vivía en Entre Ríos y trabajaba con un miembro de una secta satánica que lo pretendía en amores. Se había resistido a ese requerimiento, había probado alimentos que el mago le había cocinado a modo de galante obsequio y, a partir de entonces, había sufrido convulsiones, violencias y toda clase de fenómenos autodestructivos. Lo habían tratado médicos y psiquiatras, y un sacerdote local le había diagnosticado "posesión diabólica". Al borde del suicidio, creyendo verdaderamente que estaba tomado por el demonio, llegó a la provincia de Buenos Aires y buscó, por medio de unos parientes alarmados, a un exorcista.

(http://www.lanacion.com.ar/1151854-el-exorcista-de-la-calle-6),

Hacia un renacimiento del islam

Reconciliación. El islam, la democracia y el mundo occidental (Norma) es el legado póstumo de Benazir Bhutto, la ex primera ministra de Pakistán, asesinada en diciembre pasado, tras volver a su país después de un largo exilio

DOMINGO 06 DE JULIO DE 2008

La emoción me abrumaba cuando pisé la pista del aeropuerto internacional Quaid-e-Azam en Karachi, el 18 de octubre de 2007. Como la mayoría de las mujeres que trabajan en la política, soy especialmente cuidadosa a la hora de mantener mi compostura; intento no revelar jamás mis sentimientos. Cualquier despliegue de emoción por parte de una mujer involucrada en la política o el 
gobierno puede ser malinterpretado como una manifestación de debilidad, lo cual sólo ayuda a reafirmar estereotipos y caricaturas.

\section{(http://www.lanacion.com.ar/1027647-hacia-un-renacimiento-del-islam)}

Uno de los aspectos que configura los fenómenos de diversidad religiosa es la búsqueda de diferenciación con el supuesto "monopolio católico": en primer lugar, de las creencias en la Argentina. En segundo lugar, podríamos ampliar este supuesto con el de la convivencia en nuestro país de las religiones abrahámicas, llamadas de salvación o tradicionales. El islam, el judaísmo y el cristianismo serían parte de la cultura formada por lo que se llamó el "crisol de razas" y que produjeron las inmigraciones europeas en el Cono Sur.

Otro eje posible sería el del desvío o apego a la ortodoxia/heterodoxia en las prácticas y creencias religiosas institucionalizadas (Frigerio, 2013): la diversidad religiosa podría ser considerada hacia el interior de cada uno de los cultos en cuanto a cómo permite o restringe las manifestaciones disidentes a la hegemonía institucional, cuantitativamente: los bautismos, la comunión y la confirmación, el matrimonio religioso, la asistencia al culto, opiniones y prácticas vinculadas a la educación y a la sexualidad, entre otros indicadores del Atlas de las creencias religiosas en la Argentina (2013).

\subsection{Política y religión. Iglesias y Estado}

Las relaciones entre religión y política en la década de 2001-2010 inician y finalizan con una fuerte presencia pública de lo religioso que tuvo continuidades de la década previa y momentos de auge en este período.

Si en el comienzo de la década, la situación argentina de 2001 fue marcada por la crisis política, social y económica de la caída del gobierno de la Alianza y a nivel internacional, por el atentado a las Torres Gemelas en New York, la década finalizó en 2010 con la polémica por los debates y la sanción de la Ley 26.618 que permitió el matrimonio entre personas del mismo sexo, conocida como ley de matrimonio igualitario. 
Entre esos años se debatió, desde 2004 a 2006, y finalmente se sancionó La Ley de Educación Sexual cuya discusión pública protagonizó polémicas en 2004 y 2005 como la del entonces vicario militar Baseotto con el ministro de Salud Ginés González García; o las polémicas declaraciones de Bergoglio respecto a la muestra artística de León Ferrari que incitaron a un grupo de católicos a destruir parte de la obra; el conflicto con el campo en 2008 y las constantes "tensiones" y "gestos" de distensión entre el gobierno y el Episcopado católico argentino, todos ellos acontecimientos sociales que los medios retomaron y convirtieron en noticias.

Las figuras principales y recurrentes de la Iglesia Católica argentina sobre las que centramos las observaciones en nuestro corpus fueron las de los líderes religiosos Jorge Bergoglio, Jorge Casaretto y Héctor Aguer. Una cronología posible de las temáticas y casos periódicos en la prensa escrita nacional, a partir del corpus con el que trabajamos las noticias sobre religión en lanacion.com, clarin.com y pagina12.com en el período 2001-2010, involucra de manera inevitable relaciones múltiples y diversas entre política y religión:

\footnotetext{
2001 Crisis argentina

> 2001 Atentado a las Torres Gemelas en New York

> 2002 Mesa del Diálogo Argentino

$>2002$ Caso Grassi

$>2003$ Caso Tejerina

$>2003$ Disputas por el Tedeum

$>2004$ Muestra artística de León Ferrari y disputa con Jorge Bergoglio

$>$ 2004-2006 Ley de Educación Sexual

$>$ 2005-2007 Caso Baseotto

$>2005$ Muerte de Juan Pablo II y elección de Joseph Ratzinger

$>2006$ Coalición Cívica del obispo Joaquín Piña en Misiones, enfrentamiento con Néstor Kirchner

$>2006$ Primera diputada evangélica Cinthia Hotton

$>2007$ Condena al cura católico Von Wernich por participación en crímenes de lesa humanidad durante la dictadura

> 2007 Reunión de obispos católicos de la CELAM en Aparecida, Brasil

$>2007$ Día de la libertad religiosa y propuesta de la nueva ley de cultos

$>2008$ Actos evangélicos (Luis Palau en avenida 9 de julio)

$>2008$ Conflicto gobierno y sector agropecuario

> 2009 Declaración de Benedicto XVI por la pobreza en Argentina

$>2009$ Asignación Universal por Hijo

2010 Disputas por el Tedeum

> 2010 Ley de Matrimonio Igualitario
} 
Esas relaciones entre política y religión, además, dan cuenta de una presencia creciente del culto y los fieles evangélicos pentecostales, que se manifiesta con las llamadas megaiglesias y megafestivales, el crecimiento de los lugares de culto y de su presencia pública, según LN.COM:

\section{Rezo multitudinario de los evangélicos}

Una multitud de fieles evangélicos se congregó ayer al pie del Obelisco para orar por la paz en el mundo y la crisis que afecta a la Argentina. El encuentro fue organizado por el Consejo Nacional Cristiano Evangélico (CNCE), que reúne a las principales federaciones de iglesias de esta vertiente

\subsubsection{1 $\mid$ Cultura $\mid$ Edición impresa}

Los evangélicos oraron por el país

Una concentración de fieles evangélicos convocada por más de 600 pastores protestantes de esta capital y de la provincia de Buenos Aires colmó ayer la Plaza de Mayo, en un acto de oración para rezar por el país en medio de la profunda crisis económica, social y política. Con el lema "Argentina,

\subsubsection{2 $|\underline{\text { Cultura }}| \underline{\text { Edición impresa }}$}

$\underline{\text { Los evangélicos convocaron a una multitud en el Obelisco }}$

Sólo una fe poderosa podía ayudar a soportar el sol impiadoso de ayer por la tarde en el asfalto de la avenida 9 de Julio. Entre las tres y las seis de la tarde, mientras la temperatura y la sensación térmica superaban largamente los 32 grados, una multitud protegida con sombreros y paraguas, que

\subsubsection{4 | Cultura $\mid \underline{\text { Edición impresa }}$}

\section{$\underline{\text { Crece el fenómeno de las iglesias evangelistas }}$}

"¡Sal! ¡Te ordeno, Satanás, que abandones este cuerpo grita Mario Herrera, de 62 años, dedicado a exorcizar espíritus malignos en Plaza Miserere. Gustavo Arnauti, de 40, reparte comida y bendiciones a indigentes en el mismo espacio. Hace muchos años ambos sufrieron un fuerte sacudón en sus

\subsubsection{4 $\mid$ Información general $\mid$ Edición impresa}

\section{La conquista religiosa de la ciudad}

Luis Palau es un evange lista; la mayor o una buena parte de quienes concurrieron a verlo ayer son evangé licos. Para los evangélicos, que son quienes pertenecen a una de las ramas del protestantismo, el evangelista es un especialista en transmitir la Palabra de Dios, el mensaje bíblico, con dones

\subsubsection{8 $|\underline{\text { Cultura }}| \underline{\text { Edición impresa }}$}

\section{Fuerte rechazo frente al Congreso}

Una marea naranja rodeó ayer el Congreso. El color elegido para simbolizar la oposición al matrimonio gay formó una férrea barrera de rechazo popular al proyecto cuyo debate está previsto para hoy en el Senado. Una multitud respondió a la convocatoria de la Iglesia Católica y de sectores

\subsubsection{0 | Información general $\mid$ Edición impresa}


En el período estudiado, los medios también destacaron la elección de la primera diputada evangélica Cinthia Hotton (Algranti, 2010; Carbonelli y Mosqueira, 2008), en una alianza de la agrupación Valores Para Mi País con el partido PRO de Mauricio Macri, alianza que se deshizo en 2009 por las disputas frente al proyecto de ley de matrimonio igualitario. En CL.COM:

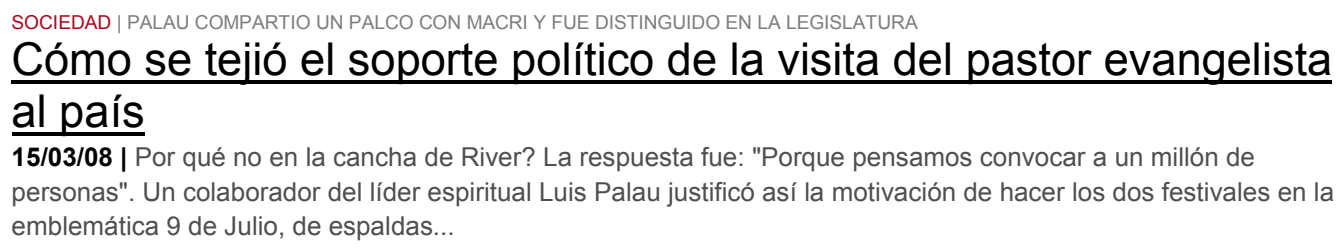

\section{Reclamo por la igualdad de todos los cultos}

28/04/08 | El Consejo para la Libertad Religiosa (CALIR) -que reúne a personalidades de los principales cultosreclamó ayer la sanción de una ley de "organizaciones religiosas" que suplante a la aprobada durante la última dictadura. Con ello, se busca...

\section{POLITICA | IDENTIKIT}

\section{La evangélica que le tiene fe a Cobos}

15/11/09 | Entró a la Cámara de Diputados en 2007 y enseguida encontró un lugar desde donde destacarse. De arranque, Cynthia Hotton difundió orgullosa su condición de cristiana evangélica y allí se paró para proponer proyectos como una nueva ley de adopción u...

\section{Católicos y evangélicos se movilizan contra la boda gay}

13/07/10 | Bajo el lema "Los chicos tenemos derecho a una mamá y a un papá", militantes católicos, evangélicos y de otros credos marcharán a partir de las 18.30 al Congreso de la Nación en rechazo al proyecto de ley de matrimonio homosexual que se tratará...

En P12.COM:

CRITICO DOCUMENTO DE LAS IGLESIAS EVANGELICAS

"UNA COMISIÓN DE LA VERDAD"

PRINCIPAL IEl país |Miércoles, 6 de febrero de 2002

\section{LOS AMIGOS DE PALAU}

> Por Washington Uranga

PRINCIPAL | Sociedad |Jueves, 30 de enero de 2003

\section{CRISTO LLAME YA!}

El crecimiento de las iglesias evangélicas desnuda un particular fenómeno social, político y económico. El periodista Alejandro Seselovsky lo investigó. Aquí, un adelanto de su libro Cristo llame ya!, de Editorial Norma.

PRINCIPAL ISociedad [Domingo, 30 de enero de 2005

FRAI BETTO CRITICA LA CRUZADA DE LA IGLESIA CONTRA LOS EVANGELICOS

\section{"EL VATICANO DEBERÍA SER MÁS UNIVERSAL"}

PRINCIPAL |EI mundo |subnota |Lunes, 14 de mayo de 2007

\section{"EL EVANGELISMO ESTÁ LLEGANDO A LAS CLASES MEDIAS"}

Las diversas ramas del protestantismo fueron ganando millones de adeptos en todo el mundo, a veces escudadas en el vínculo directo con la divinidad y otras en el más puro marketing. César Ceriani Cernadas, doctor en Antropología por la Universidad de Buenos Aires y especialista en religiones, traza un arco que va desde los 
mormones hasta la Iglesia Universal del Reino de Dios y analiza un fenómeno que, en Argentina, ya está comenzando a echar raíces en la clase media.

PRINCIPAL Dialogos 표 |Lunes, 20 de abril de 2009

\section{LOS POLÍTICOS DE CRISTO}

El nuevo sector macrista se llama Valores para mi país. En su lanzamiento estuvieron la vicejefa de Gobierno porteño, Gabriela Michetti, y los diputados Federico Pinedo y Paula Bertol. El rabino Sergio Bergman mandó un mensaje de adhesión.

PRINCIPAL IEl país 표 |Miércoles, 1 de abril de 2009

En cuanto a los vínculos entre el Estado y el Episcopado católico argentino, el gobierno de transición electo por la Asamblea Legislativa que sucedió a Fernando De la Rúa y encabezada por Eduardo Duhalde -el dirigente peronista que había competido y perdido frente a De la Rúa-, tuvo en los líderes de la Iglesia Católica argentina a uno de sus actores políticos principales a comienzos de 2002.

Junto con el PNUD de Naciones Unidas conformaron la Mesa del Diálogo Argentino: "Una instancia en la cual ninguna otra institución o grupo religioso había sido convocado e invitado a participar." (Ameigeiras, 2008: 201).

La exclusividad que lograba entonces el Episcopado católico argentino era parte de una de sus estrategias institucionales históricas (Soneira, 1989; Esquivel 2004, 2008). Evadía así la autocrítica por su rol durante el período del gobierno menemista y se presentaba como la iglesia única, el culto por antonomasia de los argentinos ${ }^{107}$.

Esa convocatoria legitimadora por parte del gobierno de transición en 2002 fue motivo de críticas desde otros sectores dado que reprodujo la ilusión de hegemonía y monopolio del catolicismo al presentar a este culto como 'reserva moral' del país y al opacar la diversidad existente en la Argentina en el terreno espiritual:

Un aspecto sobre el que se generaron cuestionamientos en relación a la participación de la Iglesia Católica en la Mesa [fueron los] referidos en particular a su participación de carácter "especial", en vez de hacerlo como una integrante más del diálogo, que debía asumir sus responsabilidades en la crisis como las otras instituciones y, sobre todo, que debía estar dispuesta a una reflexión crítica de ella misma en el contexto del país. (Ameigeiras, 2008: 216).

Sin embargo, la etapa inicial culminó con críticas de los dirigentes de la Iglesia Católica argentina a los sectores políticos que no facilitaban el acuerdo y privilegiaban los reclamos sectoriales. De la inicial Mesa del Diálogo se había pasado a una convocatoria social amplia y, sin embargo, el gobierno se retiró de la Mesa del Diálogo Ampliada:

\footnotetext{
${ }^{107}$ Una estrategia que Clarín y clarín.com imitan de la Iglesia Católica (Sivak, 2015) y que podríamos decir es propia de una posición dominante, en ambos casos, gracias a mediaciones y concesiones por parte del Estado nacional en distintos momentos históricos para ambas instituciones.
} 
Se inaugura entonces la etapa denominada "Mesa del Diálogo Ampliada". Ya no es la conformada por la Iglesia Católica y el PNUD más el Gobierno, sino una Mesa conformada por representantes de los credos fundamentales (de las comunidades judía, cristiana evangélica, islámica y católica), a los que se sumaron los de distintas instituciones y organizaciones de la sociedad civil: desde la Central de los Trabajadores Argentinos (CTA) y la Asociación Cristiana de Dirigentes Empresariales (ACDE), pasando por la Asociación Mutual Israelita Argentina (AMIA), la Delegación de Asociaciones Israelitas Argentina (DAIA) y Poder Ciudadano, hasta Conciencia, el Foro del Sector Social o la Red Solidaria. Un ámbito donde se manifiesta un amplio espectro de instituciones que intenta convertirse en espacio cívico articulador de consensos, constituido especialmente desde la sociedad civil pero ya sin una presencia directa del gobierno. (Ameigeiras, 2008: 213).

Luego del rol protagónico que tuvo la Iglesia Católica argentina en la crisis de fines de 2001 y como mediadora a comienzos de 2002, la palabra del entonces cardenal Bergoglio y otros líderes religiosos apareció en diversas noticias, de manera admonitoria respecto al gobierno de transición de Eduardo Duhalde y luego, en mayo de 2003, con el gobierno electo de Néstor Kirchner, se hicieron públicas las polémicas por la celebración del Te Deum que implicó desde el comienzo la relación "tensa" entre Estado e Iglesia Católica ${ }^{108}$.

Según publicaba P12.COM, en una nota firmada por el periodista Martín Piqué, en 2005:

La decisión del Presidente de trasladar el Tedéum a Santiago había generado polémica. Aunque había un antecedente cercano -en el 2003, Eduardo Duhalde organizó una misa en Luján con el arzobispo Rubén Di Monte-, las lecturas políticas eran obvias. Alejarse de la Catedral Metropolitana expresaba un distanciamiento con Bergoglio, arzobispo primado y animador del Tedéum cada 25 de Mayo. En el Gobierno eran conscientes de la situación: en cada funcionario se notaba un cuidado especial por transmitir humildad, apertura y hasta autocrítica. Una frase de Kirchner reflejó el clima general: "Nadie es perfecto. La Patria necesita de todos y de la verdad relativa de cada uno saldrá la verdad absoluta. Este 25 de Mayo debe servirnos para consolidar la humildad". (el destacado es nuestro, http://www.pagina12.com.ar/diario/elpais/1-51548$\underline{\text { 2005-05-26.html) }}$

En abril de 2002, lanacion.com publicaba con el título "Duhalde pidió que la Iglesia no abandone la mesa de Diálogo":

A pesar del hermetismo de las partes, esta agencia pudo saber de fuentes gubernamentales que el objetivo de Duhalde fue pedirle al cardenal Bergoglio

\footnotetext{
${ }^{108}$ El 25 de mayo de 2003 asume Néstor Kirchner como presidente electo; su gobierno insistió en realizar la celebración en diversas ciudades del interior del país. Algunos líderes de la Iglesia Católica argentina sostuvieron la tradición de hacerlo en la catedral metropolitana de la ciudad de Buenos Aires, con lo que durante varios años hubo dos celebraciones del Te Deum.
} 
que en su carácter de vicepresidente segundo el Episcopado evite una "salida intempestiva" de los tres delegados eclesiásticos -Jorge Casaretto, Juan Carlos Maccarone y Ramón Staffolani- que participan del equipo de concertación.

"La idea fue sugerirle al Arzobispo que es imprescindible la permanencia espiritual de los obispos en el diálogo y evitar así una mala lectura de la sociedad", dejaron trascender desde la Casa Rosada.

El apuro presidencial se debió a que el plenario episcopal decidirá la semana próxima, en la casa de ejercicios María Auxiliadora de San Miguel, si sigue prestando el "ámbito espiritual" para el proceso convocado por el propio titular de ejecutivo y que, con éxito dispar, mantuvo conversaciones con distintos sectores de la sociedad.

Si bien todavía no hay una posición tomada, las versiones más fuertes indicaban que hasta hoy no se le renovaría el mandato al trío dialoguista, ante la "falta de grandeza" de la clase dirigente para evitar el "colapso social e institucional" y por el "alto costo" pagado por aparecer cerca del gobierno.

(http://www.lanacion.com.ar/389721-duhalde-pidio-que-la-iglesia-no-abandonela-mesa-de-dialogo)

El rol público de Bergoglio y su visibilidad en los medios cambió a lo largo de 20012010. En 1998 Bergoglio accedió al cargo de arzobispo de Buenos Aires, que le auguraba la posibilidad de ser cardenal por la importancia de ese obispado, lo que sucedió en febrero de 2001.

La relación con el kirchnerismo fue tensa desde el comienzo de su gobierno, en 2003. Por esta posición admonitoria de la Iglesia Católica ${ }^{109}$ a la que hacíamos referencia y que ya estaba presente con la situación social de fines de 2001, en las negociaciones de la Mesa del Diálogo de comienzos de 2002, pese al "olvido" acerca del papel que tuvo el Episcopado argentino en la década de los noventa.

POLITICA | MENSAJE DE LA IGLESIA CATOLICA: LA SITUACION SOCIAL

\section{Dura crítica a la dirigencia en las homilías de Pascua 31/03/02 | La Iglesia Católica renovó ayer sus fuertes críticas a la dirigencia —especialmente la política-, a la cual reprochó por no escuchar los reclamos de la sociedad y sobre la que dirigió un profundo cuestionamiento moral. Alarmados por la crisis... POLITICA}

\section{Críticas de Bergoglio por la situación social}

10/04/02 | El arzobispo de Buenos Aires, cardenal Jorge Bergoglio, acusó ayer implícitamente al Gobierno porteño de pasividad ante un problema social, al revelar que "como resultado de un desalojo de un asentamiento, desde julio, hay en el barrio de Soldati...

\footnotetext{
${ }^{109}$ Entre muchas otras notas, puede observarse esa tensión en lanacion.com del 25 de marzo de 2002: http://www.lanacion.com.ar/383430-fastidio-ante-el-vacio-dirigencial, en lanacion.com del 28 de septiembre de 2002: http://www.lanacion.com.ar/435786-la-argentina-esta-postrada).
} 
En 2008 la disputa se profundizó con el conflicto entre el gobierno y el sector agropecuario por las retenciones impositivas al campo y en 2009 el tema de la pobreza fue mencionado en un discurso público de Benedicto XVI (véase sobre esto supra, apartado 5.5).

Las iniciales tensiones se transformarían en abierta confrontación entre el gobierno kirchnerista y la Iglesia Católica en 2010, con el debate y la sanción de la ley de matrimonio para personas del mismo sexo. Frente al Congreso Nacional hubieron marchas y manifestaciones públicas contra la ampliación del derecho de matrimonio para personas del mismo sexo, por parte de sectores religiosos conservadores.

Sobre la crisis de 2001 Bergoglio, recién nombrado cardenal en febrero de ese año, hizo declaraciones en diciembre:

POLITICA | EL TEMA DEL DOMINGO / LA CRISIS DEL NUEVO GOBIERNO: LA POSICION DEL ARZOBISPO DE BUENOS AIRES

\section{Bergoglio reivindicó el cacerolazo del viernes}

30/12/01 | La Iglesia porteña reivindicó la protesta pacífica de vecinos de la Capital Federal, que entre el viernes y ayer a la madrugada protagonizaron un nuevo cacerolazo en demanda del fin del corralito bancario. $Y$ en repudio de ciertos funcionarios del...

En 2002 participó como uno de los principales líderes religiosos y concertó reuniones entre sindicalistas, políticos, funcionarios y empresarios:

POLITICA | LA CRISIS / ESCENARIO: LAS GESTIONES ENTRE FUNCIONARIOS, EMPRESARIOS Y SINDICALISTAS

\section{Ofensiva final de la Iglesia para lograr resultados en la Mesa del Diálogo \\ 30/03/02 | Los representantes de la Iglesia y las Naciones Unidas en la Mesa de Diálogo —el nucleamiento que busca consensos que contribuyan a sortear la crisis - iniciaron una fuerte ofensiva para que el Gobierno, el Congreso, el Poder Judicial y los diversos...}

En una nota del domingo 11 de abril de 2010 titulada "Se consolida en la Iglesia el liderazgo de Bergoglio" y firmada por Mariano de Vedia, este periodista de La Nación y lanacion.com caracterizaba a los sectores de la Iglesia Católica argentina en dos tendencias:

A partir de ahí, en cada una de esas líneas se pueden encontrar posiciones cercanas a corrientes progresistas y otras identificadas con posturas más conservadoras, que los acercan o alejan, según las circunstancias, al poder político." (...) "Como ocurre en la sociedad y en los partidos políticos, es anticuado hablar de derecha y de izquierda", confió a LA NACION un colaborador del cardenal, al señalar que "pasa lo mismo que 
dentro del peronismo o en la política uruguaya: no hay divisiones tajantes". (http://www.lanacion.com.ar/1253007-se-consolida-en-la-iglesia-el-liderazgo-de-

bergoglio)

En el título, la nota identifica a 'la Iglesia' con la Iglesia Católica argentina y compara a los sectores religiosos con la política partidaria por lo que hace dos operaciones simbólicas precisas: primero en la retórica del título opera la sinécdoque (la parte por el todo) al postular a los católicos (una parte de los sectores religiosos argentinos) como la única iglesia (el todo); segundo, en la comparación metafórica asimila a la Iglesia Católica argentina con un actor político liderado por Bergoglio, cuando hace el símil: "como ocurre en la sociedad y en los partidos políticos" o "pasa lo mismo que dentro del peronismo".

En cuanto a la clasificación mediática de conservadores y progresistas (en la de lanacion.com faltaría la de 'moderados' que le atribuían justamente a Bergoglio) se hizo habitual en el período estudiado y se superpuso a otras anteriores, como las que se organizaban en torno a los cambios que introdujo el Concilio Vaticano II con posiciones de los sacerdotes denominados tradicionalistas, conservadores y renovadores (Esquivel, 2004; Obregón, 2005).

Esta construcción representacional, hecha en y por los medios, a partir de clasificaciones socio-históricas y teóricas de los sectores eclesiásticos argentinos propone una escena enunciativa donde las noticias sobre las relaciones políticas entre la Iglesia Católica y el gobierno se articularían a imagen y semejanza, en analogía podríamos decir, de las distintas facciones representativas en las relaciones políticas del Vaticano que también tendría sus sectores conservadores, moderados y progresistas ${ }^{110}$.

En el caso de la figura del arzobispo de La Plata, Héctor Aguer (otra de las palabras clave con la que buscamos las noticias en esta dimensión de análisis) los tres medios indagados clasificaron y calificaron su conservadurismo por su apego a la doctrina vaticana y al dogma- por lo que Página/12 y P12.COM lo han calificado también de "fanático", "cruzado", "ultracatólico":

\footnotetext{
${ }^{110}$ Es interesante que en este caso a partir de la elección de Bergoglio como Papa Francisco, su figura realiza un pasaje del sector moderado -en el ámbito argentino- al sector progresista -en el Vaticano- por lo que en el extranjero muchos hablaban en su momento de un Papa "revolucionario", al que se lo comparaba con el Che Guevara, por la procedencia biográfica de haber nacido en la Argentina y frente al conservadurismo que representaba y encarnaba la figura de Ratzinger.
} 


\section{UN CRUZADO DE RATZINGER}

Abanderado de la ultraderecha católica, el arzobispo de La Plata velará por la formación de las futuras generaciones. Un repaso de sus ideas a través de sus propias expresiones.

PRINCIPAL |EI país 표 |Domingo, 16 de noviembre de 2008

\section{LOS ÚLTIMOS CARTUCHOS DE LA CRUZADA}

Diversos sectores eclesiásticos reclaman un plebiscito, promueven un petitorio y aleccionan a los alumnos de las escuelas confesionales. El ministro de Educación, Alberto Sileoni, advirtió que es un "abuso" esa utilización de los chicos.

PRINCIPAL | Sociedad |ㅛㅛ |Viernes, 2 de julio de 2010

En su filiación político-partidaria a Aguer se lo ha considerado como cercano al menemismo y en sus polémicas por la educación, la educación sexual y el matrimonio igualitario, como crítico del gobierno kirchnerista. Un ejemplo de CL.COM:

SOCIEDAD | NO CEDE LA POLEMICA

Educación sexual: duro cruce entre un arzobispo y un ministro

01/11/05 | La polémica con la Iglesia por el modo en que se imparte la educación sexual en los colegios reapareció ayer con fuerza. El ministro de Salud, Ginés González García, criticó duramente al arzobispo de La Plata, monseñor Héctor Aguer, quien había...

En página12.com:

\section{LA EDUCACIÓN SEXUAL Y LOS ELEFANTES}

El arzobispo Héctor Aguer consideró "farragoso", "ateo" y de "inspiración neomarxista" un manual oficial para formadores escolares en sexualidad. Aquí le responden la dirigente docente Stella Maldonado y el profesor Sergio Wischñevsky.

PRINCIPAL |El país |묘 |Martes, 4 de agosto de 2009

\section{OPORTO: "NO ME GUSTA EL TONO ACUSATORIO CON TERMINOLOGÍA} PROCESISTA"

\footnotetext{
El director General de Escuelas bonaerense, Mario Oporto, calificó de "totalitario y procesista" el tono de las declaraciones del arzobispo platense, Héctor Aguer, quien criticó el contenido de manuales para docentes que imparten educación sexual a alumnos.

PRINCIPAL |Ultimas Noticias |subnota |Jueves, 30 de julio de 2009
}

Considerado un discípulo del cardenal en el Vaticano Leonardo Sandri, Aguer se formó como seminarista en la época de la última dictadura cívico-militar de la Argentina, entre 1976-1983. Los medios de comunicación han publicado noticias acerca de su 
rivalidad $^{111}$ con Jorge Bergoglio, quien era identificado en ese momento con el sector moderado de las autoridades religiosas de la Iglesia Católica argentina, antes de ser nombrado Papa en 2013.

En el 2003 el nombre de Aguer volvió a tener presencia mediática a partir de sus declaraciones polémicas en torno a la educación sexual:

\title{
SOCIEDAD I LA HIZO EL ARZOBISPO PLATENSE
}

\section{Crítica a la educación sexual en las escuelas}

17/05/03 | El arzobispo de La Plata, Héctor Aguer, cuestionó la educación sexual "basada en la genitalidad y promotora de la práctica del sexo seguro". El prelado realizó una defensa de la

"educación para el amor", en el transcurso de una jornada de reflexión...

La Ley de Salud Reproductiva y la derogación de las leyes de Obediencia Debida y Punto Final, junto al decreto que impedía extradiciones de represores de la última dictadura cívico-militar argentina, fueron ocasiones en las que Aguer pronunció su disconformidad de manera pública y polémica. Clarín y CL.COM retomaron sus declaraciones en forma de noticias:

\section{POLITICA | EXTRADICIONES Y LEYES DE PERDON}

\section{Dura crítica de un obispo}

14/07/03 | El arzobispo de La Plata, monseñor Héctor Aguer, criticó implícitamente en duros términos a quienes consideran inconstitucionales las leyes de Punto Final y Obediencia Debida y a los que propician la anulación del decreto que impide la extradición...

SOCIEDAD | SANCIONAN LA LEY DE SALUD REPRODUCTIVA EN LA PROVINCIA DE BUENOS AIRES

\section{Podrán recetar anticonceptivos en los hospitales bonaerenses}

28/05/03 | El parlamento bonaerense sancionó una legislación para proveer métodos anticonceptivos a las pacientes atendidas en hospitales y centros sanitarios. La denominada Ley de Salud Reproductiva y Procreación Responsable promueve también un programa de...

En el cuerpo del texto de esta última noticia refiere que:

\begin{abstract}
"El programa de Salud Reproductiva bonaerense amenaza con abrir una polémica con sectores eclesiásticos. Antes de su tratamiento en la Legislatura, el arzobispo de La Plata, Héctor Aguer advirtió sobre "la cultura fornicaria que se nos impone tiránicamente desde las escuelas". El prelado cuestionó la "educación sexual basada en la genitalidad y promotora de la práctica del sexo seguro". En La Plata se escucharon las primeras oposiciones a la normativa. La Pastoral Familiar de la capital bonaerense se solidarizó con la "preocupación manifestada por Aguer".".
\end{abstract}

${ }^{111}$ Estas notas "de fondo" o artículos han aparecido más que nada en revistas políticas: http://www.latecla.info/3/nota 1.php?noticia id=57467, http://www.lapoliticaonline.com/nota/68861/, http://www.lapoliticaonline.com/nota/68221/ 
La legislación sobre educación sexual en las escuelas, cuyo debate fue iniciado en 2004 y hasta 2006 no logró sanción como Ley de Educación Sexual, y obtuvo la oposición del Episcopado católico argentino. La implementación de la ley fue lenta y todavía es incompleta $^{112}$.

\section{INFORMACIÓN GENERAL I VALORES RELIGIOSOS: LA MIRADA DE EDUCADORES CATOLICOS \\ "La Iglesia no se opone a la educación sexual en sus aulas" \\ 06/04/04 | Las autoridades educativas pueden pedirle a los colegios de gestión privada la inclusión de la educación sexual, pero no deben obligarles a enseñar determinados contenidos", señaló el director del Instituto de Bioética de la Universidad Católica... \\ SOCIEDAD | DISPOSICION DE LA DIRECCION DE ESCUELAS DE LA PROVINCIA DE BUENOS AIRES \\ La Iglesia se resiste, pero garantizarán con inspectores la educación sexual escolar \\ 04/03/04 | La Dirección de Escuelas bonaerense pondrá 222 inspectores para garantizar que todos los colegios privados — laicos o religiosos - cumplan con la ley que dispone la inclusión de educación sexual en los programas de estudio. Los supervisores visitarán... \\ SOCIEDAD | LA IGLESIA \\ "Una norma tiránica" \\ 03/03/04 | La Iglesia es reacia a que el Estado le imponga contenidos sobre educación sexual a sus colegios porque teme que se centre "sólo en lo genital y no en la integridad de la persona humana". El arzobispo de La Plata, monseñor Héctor Aguer, denunció el...}

Según el corpus de noticias de Clarín y CL.COM, durante 2004 hubo una serie de críticas entre el entonces presidente Néstor Kirchner y los obispos.

La principal crítica del Episcopado católico argentino fue por la situación social y por las manifestaciones piqueteras. Uno de sus principales voceros fue Aguer, a quien Néstor Kirchner le respondió recordando su pasado como garante de $\operatorname{Trusso}^{113}$ y la estafa a miles de ahorristas en 2001 con la quiebra del Banco Crédito Provincial.

La polémica creció hasta culminar en las declaraciones del vicario castrense Baseotto al comparar, durante la ceremonia de zarpada del buque 'Bahía San Blas' rumbo a Haití, la inseguridad en la Argentina con la situación de emergencia humanitaria que los efectivos encontrarían en Haití ${ }^{114}$ :

\section{POLITICA | DURO MENSAJE DEL OBISPO CASTRENSE \\ El buque San Blas parte hoy hacia Haití}

\footnotetext{
112 En algunas provincias como Salta, la educación religiosa católica sigue dictándose incluso en las escuelas de gestión pública.

${ }^{113}$ Francisco Trusso fue un banquero condenado a ocho años de prisión por fraude en el Banco Crédito Provincial y cuya excarcelación dependió del aval presentado por el arzobispo de La Plata, Héctor Aguer, dispuesto como fiador personal por la suma de un millón de pesos en 2003.

114 http://www.pagina12.com.ar/diario/elpais/1-38280-2004-07-17.html
} 
17/07/04 | Pareció una ironía del destino. La ceremonia de zarpada del buque de la Armada "Bahía San Blas" a Haití no fue empañada por un escrache de la izquierda, como se temía, pero el mal trago para el Gobierno igualmente llegó, y del costado menos pensado.... POLITICA | RELACIONES COMPLICADAS

\section{Por ahora, la Iglesia y Kirchner no se reunirán}

15/07/04 | Quizás inspirado en la parábola del buen samaritano, que se leyó en las misas del domingo pasado, el ministro del Interior, Aníbal Fernández, procuró en los últimos días sanar las heridas de la relación entre el presidente Néstor Kirchner y la...

POLITICA | NUEVA SEÑAL DE DISTENSION CON LA IGLESIA

\section{Kirchner dijo que espera a los obispos "con los brazos} abiertos"

10/07/04 | La intención era esta vez no confrontar y, por el contrario, mostrar gestos de acercamiento hacia la Iglesia. Sin embargo, el presidente Kirchner tuvo que escuchar desde un púlpito un reclamo dirigido "a toda la sociedad, pero sin duda a la...

Esa polémica que se inició con el contenido específico de la "inseguridad" tuvo en 2005 un desarrollo, respecto a las discusiones públicas sobre la Ley de Educación Sexual que se debatía sin conseguir aprobación, que alarmó a la Iglesia Católica y que sumó reacciones de rechazo del gobierno y de algunas personalidades de la sociedad civil (véase el apartado 5.2).

La polémica alimentada de críticas entre gobierno y obispos había tenido como protagonistas de la Iglesia Católica, además de Héctor Aguer, a los obispos Olmedo y Musto según CL.COM. La defensa pública del obispo castrense Baseotto fue asumida con énfasis por Aguer y preocupó a Bergoglio:

\section{POLITICA | ADVERTENCIA DEL ARZOBISPO DE BUENOS AIRES, CARDENAL BERGOGLIO}

\section{La Iglesia, preocupada por la escalada}

17/07/04 | Si el Gobierno cree que solo un puñado de obispos conservadores están preocupados por la escalada violenta de las protestas sociales, ya es tiempo de que revea su evaluación.

Cada vez más miembros del Episcopado expresan su temor. Ahora —en...

La polémica que menciona clarín.com probablemente se acentuó por las tensiones políticas entre el kirchnerismo y la Iglesia Católica, y a su vez reforzó el apoyo de los líderes católicos a las protestas por las retenciones al sector agropecuario en 2008 y las disputas por el matrimonio igualitario en 2010, tensiones que sólo concluyeron con la elección de Bergoglio como Papa en 2013 al proyectarlo a un liderazgo mundial.

En 2005, cuando se produjo el incidente de la carta del obispo castrense Baseotto al ministro de Salud Ginés González García por sus declaraciones en favor de la despenalización del aborto para terminar con las muertes maternas, clarín.com publicó: 


\section{El obispo castrense dijo que el ministro de Salud merecería ser "tirado al mar"}

18/02/05 | El ala dura de la Iglesia no deja pasar ninguna declaración del ministro de Salud, Ginés González García, donde este defienda la despenalización del aborto, la difusión de métodos anticonceptivos que la Iglesia juzga abortivos —como el DIU— o el...

SOCIEDAD | POR LA POSICION DE GONZALEZ GARCIA SOBRE AL ABORTO Y EL REPARTO DE PRESERVATIVOS

\section{Silencio del Episcopado en la polémica entre un vicario y el ministro de Salud}

20/02/05 | Mientras la cúpula del Episcopado optó por el silencio más absoluto -lo que parece un intento de ceñir el incidente a un problema puntual entre un religioso y el Gobierno- la durísima carta que el obispo castrense, monseñor Antonio Baseotto, envió...

En 2005 tras la muerte de Juan Pablo II, Joseph Ratzinger es electo Papa pero la polémica entre la Iglesia Católica argentina y el gobierno continuó, en particular, entre el sector conservador del catolicismo que se imaginaba mejor posicionado con la elección de Ratzinger:

\section{POLITICA | KIRCHNER Y SU VINCULO CON LA IGLESIA \\ Una relación difícil y que todavía no consigue ser encauzada}

06/07/05 | La decisión de desplazar a monseñor Baseotto del obispado castrense que se apresta a tomar El Vaticano permitirá destrabar una situación harto delicada que se había planteado en los últimos meses luego de que el presidente Néstor Kirchner decidió...

POLÍTICA | MONSEÑOR AGUER

\section{Un obispo denunció amenazas}

30/08/05 | El arzobispo de La Plata, monseñor Héctor Aguer, fue amenazado de muerte a través de una llamada telefónica anónima recibida en la sede de la curia platense, según denunció ayer el propio arzobispado ante la Justicia. Fuentes eclesiásticas dijeron...

POLÍTICA | LA RECOMPOSICION DE UN VINCULO EN PERMANENTE TENSION

\section{La Iglesia ahora espera el diálogo}

25/10/05 | Luego de lo fortalecido que salió el Presidente en las elecciones, la Iglesia espera que Néstor Kirchner abandone la confrontación y se abra al diálogo con la oposición y todos los sectores. Fuentes de la conducción del Episcopado dijeron ayer que...

SOCIEDAD | NO CEDE LA POLEMICA

\section{Educación sexual: duro cruce entre un arzobispo y un ministro}

01/11/05 | La polémica con la Iglesia por el modo en que se imparte la educación sexual en los colegios reapareció ayer con fuerza. El ministro de Salud, Ginés González García, criticó duramente al arzobispo de La Plata, monseñor Héctor Aguer, quien había...

En 2005 continuaban las polémicas entre el gobierno nacional y los líderes del episcopado católico argentino. Según clarín.com: 


\section{Un cardenal moderado frente al desafío de un difícil}

\section{equilibrio}

08/11/05 | Dicen que es muy difícil saber qué piensa un jesuita. Ya no es fácil muchas veces escudriñar en la mente de un cardenal. ¿Qué hará Bergoglio, jesuita y cardenal, como "jefe" de la Iglesia argentina? De perfil moderado, preocupación social y nada...

\section{SOCIEDAD | OPINION}

\section{Una señal dirigida a la Iglesia}

$\mathbf{0 8 / 1 1 / 0 5}$ | Con el despido del funcionario que repartió preservativos y anticonceptivos orales en una escuela a chicos de entre 11 y 13 años, el Gobierno envió una fuerte señal conciliatoria hacia la Iglesia. Si bien se trató de una decisión de la gobernación...

POLÍTICA | COMENZO EL PLENARIO DE OBISPOS

\section{El Episcopado trata de evitar una nueva polémica con el Gobierno}

07/11/05 | El centenario de obispos del país iniciaron ayer un plenario clave con el extendido ánimo de no quedar atrapados en la virulenta polémica que se originó luego de que el arzobispo de La Plata, monseñor Héctor Aguer, denunciara el reparto de...

SOCIEDAD | POLEMICA EN LA PROVINCIA DE BUENOS AIRES

\section{Nadie se hace cargo del reparto de anticonceptivos en una escuela}

03/11/05 | Quién entregó anticonceptivos a niños de 11 y 12 años de una escuela pública de La Plata? Las autoridades educativas y sanitarias de la Provincia no tienen la respuesta a casi una semana de la polémica iniciada cuando padres de $6^{\circ}$ y $7^{\circ}$ año de la EGB...

El 23 de octubre de 2006 fue promulgada la Ley 26.150, llamada Programa Nacional de Educación Sexual Integral. En 2008, Aguer se pronunció en calidad de miembro permanente de la Comisión Episcopal de Educación Católica contra los contenidos de la enseñanza de educación sexual en las escuelas:

\section{SOCIEDAD | PARA MONSEÑOR AGUER, LA MATERIA CONSTRUCCION DE CIUDADANIA ES "NEOMARXISTA" \\ Polémica crítica de un arzobispo al nuevo secundario bonaerense \\ 22/02/08 | El arzobispo de La Plata, Héctor Aguer, criticó con dureza uno de los pilares de la reforma educativa bonaerense: calificó de "neomarxista" y de "instrumento peligroso de ideologización de los adolescentes" a la asignatura Construcción de...}

POLITICA I CRECE LA TENSION ENTRE LA CUPULA ECLESIASTICA Y LA CASA ROSADA

\section{Vaivenes de una relación complicada}

23/04/07 | 1. La relación entre el Gobierno de Néstor Kirchner y la Iglesia comenzó a complicarse cuando la Casa Rosada nominó a Carmen Argibay para la Corte y esta se declaró atea militante y a favor de la despenalización del aborto. Tiempo después, el..

Como en esta última noticia, CL.COM no deja de publicar informaciones que relatan las relaciones de la Iglesia Católica y el gobierno nacional a lo largo del tiempo; también este discurso periodístico reconstruye la cronología de acontecimientos, narra la 
participación de los actores sociales, analiza causas y consecuencias de los debates públicos.

El tratamiento pretendía ser objetivo y neutral aunque caracterizaciones como las de 'política gestual' de Bergoglio ya comenzaban a destacarse en la visibilidad mediática construida por Clarín:

POLITICA | EL IMPACTO DEL AJUSTE: DOCUMENTO DE LA CUPULA CATOLICA Y OTROS CULTOS CRISTIANOS

\section{Gestión de dirigentes religiosos para disminuir la tensión social}

01/08/01 | En un gesto conjunto inédito que revela hasta dónde preocupa el momento actual, la Iglesia católica y las demás confesiones cristianas tradicionales se comprometieron ayer a promover mancomunadamente un acercamiento entre los diversos

POLÍTICA | DESPUES DEL CASO BASEOTTO

\section{Gestos públicos entre la Iglesia y el Gobierno}

07/09/05 | El Gobierno y la Iglesia intercambiaron anoche los primeros gestos públicos de acercamiento luego del fuerte cortocircuito que produjo el caso de monseñor Baseotto. La presentación de un libro sobre América Latina del subsecretario del Consejo para...

POLITICA | KIRCHNER Y BERGOGLIO PODRIAN REUNIRSE EN POCO TIEMPO

\section{El Gobierno y la Iglesia cruzaron fuertes gestos de acercamiento}

06/03/06 | La presentación de un compendio de los documentos de los obispos de las últimas décadas sobre la situación nacional en el marco del aporte del catolicismo al retorno y la consolidación de la vida democrática permitió ayer que el Gobierno ensayara...

POLITICA | LA RELACION DE KIRCHNER CON LOS OBISPOS

\section{Antecedentes}

16/07/07 | Un vínculo distante. Desde la llegada de Néstor Kirchner a la Presidencia, hace más de cuatro años, la relación entre el Gobierno y la Iglesia fue fría, distante, conflictiva. Aunque hubo, es verdad, algunos gestos tendientes al acercamiento, nunca... POLITICA | GESTO DE ACERCAMIENTO DE LA IGLESIA A LA PRESIDENTA ELECTA

\section{Bergoglio felicitó a Cristina por carta y se comprometió a rezar por su gestión}

01/11/07 | Después de más de tres años de haber estado en un potente freezer, las relaciones entre el matrimonio presidencial y el Episcopado comienzan a mostrar tenues señales de descongelamiento. Pruebas al canto: la cúpula del Episcopado -encabezada por el... POLÍTICA | LA RELACION DEL NUEVO GOBIERNO CON LA CUPULA ECLESIASTICA

\section{Reacción positiva de la Iglesia ante los primeros gestos de Cristina}

$\mathbf{3 0 / 1 0 / 0 7 ~ | ~ L a s ~ u ́ l t i m a s ~ s e n ̃ a l e s ~ c o m o ~ c a n d i d a t a ~ y ~ l a s ~ p r i m e r a ~ c o m o ~ p r e s i d e n t e ~ e l e c t a ~ d e ~ C r i s t i n a ~}$ Fernández de Kirchner cayeron bien en la Iglesia. Tanto "su actitud conciliadora" que pronunció la noche del domingo, cuando despuntaba su triunfo, como la...

POLÍTICA | GESTO POLITICO DEL JEFE DEL EPISCOPADO ARGENTINO

\section{Para acortar distancias, Bergoglio le pedirá una audiencia a Cristina}

01/12/07 I Luego de que hoy toque suelo argentino, tras haber estado dos semanas en El Vaticano, el presidente del Episcopado, cardenal Jorge Bergoglio, dará una instrucción precisa a sus colaboradores, esperada durante mas de tres años por todos aquellos que... 


\section{Otro gesto de los obispos: esta semana piden ver a}

\section{Cristina}

10/12/07 | En un paso clave para reforzar el incipiente acercamiento entre el Gobierno y la

Iglesia, la Conferencia Episcopal se apresta a solicitarle esta semana una audiencia a la presidenta Cristina Fernández de Kirchner. Fuentes eclesiásticas dijeron que...

POLÍTICA | UNA CITA CARGADA DE GESTOS

\section{Medallas y puntos en común}

19/12/07 | Si se quería apostar al comienzo de una nueva etapa en la relación entre el Gobierno y la Iglesia, los significativos gestos que poblaron ayer la reunión entre Cristina Fernández de Kirchner y la cúpula de la Iglesia encabezada por el cardenal Jorge...

En 2009 el diario Clarín y su edición online CL.COM vuelven a publicar una noticia que ya en 2008 (la citamos más arriba y aquí debajo de nuevo) había publicado de manera casi idéntica: similar título y volanta con contenidos específicos similares y el planteo enunciativo de la polémica en el título, tales componentes hacían contacto con el posible lector:

\section{SOCIEDAD | ASEGURO QUE TIENE CONTENIDOS "NEOMARXISTAS" E IGNORA LA MORAL CRISTIANA \\ Polémica: el obispo de la Plata otra vez embistió contra la educación pública \\ 21/06/09 | El arzobispo de La Plata y principal referente de la comisión episcopal de Educación Católica, monseñor Héctor Aguer, denunció que la enseñanza que reciben los estudiantes en las escuelas públicas está "inficionada de una gran dosis de ideología" y... \\ Polémica crítica de un arzobispo al nuevo secundario bonaerense \\ 22/02/08 | El arzobispo de La Plata, Héctor Aguer, criticó con dureza uno de los pilares de la reforma educativa bonaerense: calificó de "neomarxista" y de "instrumento peligroso de ideologización de los adolescentes" a la asignatura Construcción de...}

Con la discusión de la ley llamada de matrimonio igualitario, Aguer salió a reprochar a Daniel Scioli, gobernador de la provincia de Buenos Aires en ese entonces, por no haber intervenido. De manera similar, algunos meses antes, Bergoglio lo había hecho con Mauricio Macri, jefe de gobierno de la Ciudad Autónoma de Buenos Aires por aquellos años:

\section{SOCIEDAD}

\section{Dura crítica del arzobispo de La Plata a Scioli}

29/05/10 | El arzobispo de La Plata, Héctor Aguer, consideró que el gobernador bonaerense Daniel Scioli "faltó gravemente a su deber" al no apelar el fallo judicial que permitirá el casamiento entre dos mujeres, a la vez que calificó el hecho como una... 


\section{El cardenal Bergoglio le recriminó a Macri su apoyo al matrimonio gay}

24/11/09 | La cúpula de la Iglesia Católica, encabezada por el arzobispo de Buenos Aires, cardenal Jorge Bergoglio, se reunió este mediodía con el jefe de Gobierno porteño, Mauricio Macri. Hubo varios temas de agenda, como la pobreza, pero también una...

LN.com presenta la voz de Aguer como "autorizada" en las temáticas de educación y sexualidad, dos temas por los que suele ser consultado o suele generar polémicas el arzobispo platense. El diario La Nación y lanacion.com también utilizaba la presentación del nombre del religioso en el título ${ }^{115}$, en tanto una de las voces de autoridad representativas de la Iglesia Católica argentina:

$\underline{\text { Aguer se quejó de las "presiones violentas" en el conflicto escolar }}$ ...arzobispo de La Plata, monseñor Héctor Aguer. Y continúa: "En su momento he confiado...sentirse desilusionados con la postura de Aguer y reiteraron que no enviarán a sus hijos...ayer, parecía no ceder, a pesar de que Aguer intervino el colegio el viernes pasado...

26.03.2002 $\mid$ Cultura $\mid \underline{\text { Edición impresa }}$

"Aún no salimos de la crisis", dijo Aguer

...El arzobispo de La Plata, Héctor Aguer, afirmó que los argentinos

"todavía...interna y en su proyección social". Aguer hizo estas declaraciones al anunciar el lanzamiento...la que todavía no hemos salido", dijo Aguer, que "se ha manifestado de un modo duro...

20.07.2003 $|\underline{\text { Cultura }}| \underline{\text { Edición impresa }}$

Aguer deploró la clonación

...mundo mejor", el arzobispo de La Plata, monseñor Héctor Aguer, criticó duramente las supuestas clonaciones de la secta de....aprendices a los sabios de Hitler." Al comenzar el programa, Aguer expresó: "Seguramente ustedes se enteraron de que el 28 de...

13.01.2003 $\mid \underline{\text { Cultura } \mid \text { Edición impresa }}$

${ }^{115}$ En el caso de las noticias sobre Bergoglio y Casaretto sucede lo mismo. Si bien respecto de otros religiosos no es similar su tratamiento informativo, también es cierto que se trata de un recurso periodístico para construir la cita directa o indirecta en la representación gráfica de la voz de quien habla. 
En todas estas noticias, LN.COM presenta de manera distanciada a Aguer como un religioso influyente junto con Bergoglio y Casaretto, principales referentes de los sectores eclesiásticos conservador, moderado y progresista, respectivamente, del Episcopado católico argentino.

LN.COM no suele presenta adjetivación en los títulos, aunque en el siguiente caso aparece una valoración explícita:

\section{$\underline{\text { Recelo de }}$ Aguer ante un congreso}

...y otros temas. El arzobispo de La Plata, monseñor Héctor Aguer, dijo que "la Iglesia previó enviar mujeres capacitadas....para aceptar la división clasista en el matrimonio". Según Aguer, congresos de este tipo "insisten en el alejamiento del concepto...

19.08.2001 | Cultura $\mid \underline{\text { Edición impresa }}$

En el uso de figuras retóricas que construyen ironías y sarcasmos en los títulos y bajadas, en las fotos seleccionadas, en los tonos y en el tratamiento informativo, Página/12 y P12.com cuestionan las declaraciones públicas del religioso por considerarlas de extrema derecha, conservadoras e incluso anacrónicas:

\section{AGUER AGITA LAS MANIFESTACIONES CONTRA EL MATRIMONIO GAY}

Organizaciones religiosas marcharán mañana contra el proyecto de matrimonio homosexual, en una movilización que denominaron "Caravana y acto por la familia". Los convocantes iniciarán una caravana automovilística desde Avenida 1 y 32, y se concentrarán en Plaza San Martín, a las 16.

PRINCIPAL | Ultimas Noticias |Sábado, 3 de julio de 2010

\section{LOS ÚLTIMOS CARTUCHOS DE LA CRUZADA}

Diversos sectores eclesiásticos reclaman un plebiscito, promueven un petitorio y aleccionan a los alumnos de las escuelas confesionales. El ministro de Educación, Alberto Sileoni, advirtió que es un "abuso" esa utilización de los chicos.

PRINCIPAL ISociedad 国 |Viernes, 2 de julio de 2010

Los contenidos específicos y motivos temáticos de las noticias suelen ser los que hemos marcado anteriormente y son compartidos con los de CL.COM y LN.COM: el matrimonio igualitario, la educación sexual, la pobreza.

En cuanto a la enunciación, P12.COM vuelve a presentarse como un diario laico, a favor de la despenalización del aborto, por eso califica de retrógradas las posiciones de la Iglesia Católica y en particular las posiciones de líderes religiosos como Aguer en 
contraposición a las de los llamados 'curas villeros' o las posiciones progresistas representadas en este medio en figuras como la de Casaretto.

En el caso de la palabra clave Bergoglio sucede algo bien distinto a lo que señalábamos con la palabra clave anterior: en el período estudiado, sus contenidos específicos se relacionan con una variedad de temas de actualidad política, económica y social.

Esas noticias dan cuenta de los espacios públicos mediáticos que este líder religioso fue asumiendo desde que reemplazó a Antonio Quarracino como arzobispo de Buenos Aires y como cardenal primado de la Argentina, a partir del 21 febrero de 2001.

Las noticias seleccionadas en el corpus se relacionan, entre otras, con la presidencia de Bergoglio en la Conferencia Episcopal Argentina (CEA) entre noviembre de 2005 y noviembre de 2011, es decir, durante dos períodos consecutivos. Con el cónclave papal de 2005 comenzaron a publicarse con mayor asiduidad noticias sobre Bergoglio como posible sucesor de Juan Pablo II. Finalmente fue electo Joseph Ratzinger, quien bajo el nombre de Benedicto XVI renunció al papado en 2013. En febrero de ese año fue elegido el Papa Francisco.

Los contenidos específicos de la palabra clave Bergoglio se relacionan con el supuesto conflicto por la celebración del Te Deum, sus declaraciones en el juicio por la causa ESMA ${ }^{116}$.

También respecto de noticias que trataron sobre inseguridad ciudadana, el debate y la sanción de la ley conocida como ley de matrimonio igualitario; las reuniones del entonces cardenal con distintas fuerzas políticas y con el gobierno, sus declaraciones sobre la pobreza, los trabajadores "esclavos" y la trata de mujeres en el país.

Bergoglio fue considerado por los tres medios uno de los representantes de los sectores moderados de la Iglesia Católica argentina e identificado con el peronismo, en términos político-partidarios. Las notas de Horacio Verbitsky en Página/12 y P12.COM denunciando la supuesta complicidad de Bergoglio durante la última dictadura cívicomilitar argentina fueron frecuentes ${ }^{117}$.

En cambio, Clarín y CL.COM presentó su habitual enunciación distanciada que ya hemos señalado, incluso en el caso del suplemento Valores Religiosos, la asociación

\footnotetext{
${ }^{116}$ Escuela Superior de Mecánica de la Armada que funcionó como centro clandestino de detención de personas que fueron desaparecidas por la dictadura cívico-militar entre 1976-1983.

${ }_{117}$ También es cierto que esa frecuencia decayó en cuanto fue elegido como máxima autoridad de la Iglesia Católica.
} 
de mismo nombre que dirigía el sacerdote Guillermo Marcó cuando era vocero de Bergoglio y la relación con el periódico tanto impreso como digital.

A diferencia de los otros medios, La Nación y LN.COM presentaba a Bergoglio como un importante líder religioso que además era lector y columnista habitual del diario en el que publicaban como textos completos sus declaraciones, sermones y homilías.

En 2002 participó como uno de los principales líderes religiosos de la Mesa del Diálogo Argentino y concertó reuniones entre distintos sectores. Según CL.COM:

POLITICA | LA CRISIS / ESCENARIO: LAS GESTIONES ENTRE FUNCIONARIOS, EMPRESARIOS Y SINDICALISTAS

\title{
Ofensiva final de la Iglesia para lograr resultados en la
} Mesa del Diálogo

\author{
30/03/02 | Los representantes de la Iglesia y las Naciones Unidas en la Mesa de Diálogo —el \\ nucleamiento que busca consensos que contribuyan a sortear la crisis - iniciaron una fuerte \\ ofensiva para que el Gobierno, el Congreso, el Poder Judicial y los diversos...
}

POLITICA | MENSAJE DE LA IGLESIA CATOLICA: LA SITUACION SOCIAL

\section{Dura crítica a la dirigencia en las homilías de Pascua}

31/03/02 | La Iglesia Católica renovó ayer sus fuertes críticas a la dirigencia —especialmente la política-, a la cual reprochó por no escuchar los reclamos de la sociedad y sobre la que dirigió un profundo cuestionamiento moral. Alarmados por la crisis...

POLITICA

\section{Críticas de Bergoglio por la situación social}

10/04/02 | El arzobispo de Buenos Aires, cardenal Jorge Bergoglio, acusó ayer implícitamente al Gobierno porteño de pasividad ante un problema social, al revelar que "como resultado de un desalojo de un asentamiento, desde julio, hay en el barrio de Soldati...

POLITICA | EL NUMERO UNO DE LA IGLESIA ARGENTINA, FRENTE A LA CRISIS

\section{Bergoglio, un jesuita al que le gusta aparecer muy poco y decir bastante}

14/04/02 | Suele decirse que el jesuita — por su rigurosa formación_ es un sacerdote acerca del cual nunca se sabe qué es lo que piensa realmente, una persona inescrutable; en fin, todo una incógnita. El arzobispo de Buenos Aires, Jorge Mario Bergoglio, de 64...

En 2003, las noticias que se relacionaban con la palabra clave Bergoglio tenían, por un lado, al nuevo gobierno como protagonista y por otro continuaban el rol de la Iglesia Católica como mediadora de diversos sectores sociales en pugna.

Una inesperada situación por el Te Deum de ese año generó que se realizaran dos ceremonias, como luego sucedió en otros años ${ }^{118}$ a raíz de los conflictos entre el gobierno kirchnerista y la Iglesia Católica, según CL.COM:

\footnotetext{
${ }^{118}$ En esta nota de P12.COM se menciona los dos Te Deum de 2003 como antecedente de la situación en 2005: http://www.pagina12.com.ar/diario/elpais/1-51548-2005-05-26.html
} 


\section{La idea de dos Tedéum abrió una polémica}

21/05/03 | La coincidencia de traspaso del mando con la conmemoración del 25 de Mayo suscitó una insólita situación. Por primera vez en casi 200 años de historia, podría haber dos Tedéum para celebrar la fecha patria. La única diferencia es que uno sería por...

La continuidad del rol del Episcopado argentino respecto a la crisis de 2001 tuvo un documento publicado por los obispos que, según sus declaraciones, le "daban crédito" al nuevo gobierno de Néstor Kirchner:

POLITICA | DOCUMENTO SOBRE LA CRISIS POLITICA, SOCIAL Y CULTURAL

\section{Los obispos hacen hoy un diagnóstico severo}

30/05/03 | Los obispos finalizarán hoy su primer plenario del año con la difusión de un extenso documento que contiene un severo diagnóstico político, social y cultural del país de los últimos años. El texto, de unas 30 carillas, será presentado este mediodía...

Las declaraciones de Bergoglio por la salud de Juan Pablo II también ocuparon espacio entre las noticias de 2003 y en 2004 el rechazo de la Iglesia Católica a la designación de Carmen Argibay a la Corte Suprema generó tensiones con el gobierno nacional por la posición pública de la jurista que se declaraba atea y a favor de la despenalización del aborto. Además, Argibay estaba en contra de los símbolos religiosos en las salas judiciales y en los espacios públicos en general:

\section{POLITICA | DESPUES DE LAS CRITICAS DEL EPISCOPADO A LA CANDIDATA A LA CORTE \\ Argibay, un toque de atención en la relación entre Kirchner y la Iglesia}

$\mathbf{0 8 / 0 2 / 0 4 ~ | ~ L a s ~ c r i ́ t i c a s ~ q u e ~ l o s ~ o b i s p o s ~ h i c i e r o n ~ e s t a ~ s e m a n a ~ a ~ l a ~ c a n d i d a t a ~ o f i c i a l ~ p a r a ~ c u b r i r ~ o t r a ~}$ vacante en la Corte Suprema de Justicia, Carmen Argibay, por autodefinirse como "atea militante" y también a favor de la despenalización del aborto, pusieron...

La situación social en 2004 también fue uno de los contenidos específicos de la relación entre la conducción de la Iglesia Católica argentina y el gobierno, relación que a poco de asumir el nuevo gobierno ya era una temática frecuente en los medios:

POLITICA | POLEMICA EN TORNO A LA SITUACION SOCIAL Y AL CONFLICTO PIQUETERO

\section{Dura respuesta de Kirchner a críticas que formulan obispos}

06/07/04 | En un nuevo frente de conflicto, el presidente Néstor Kirchner ayer criticó -y con dureza- a "algunos pastores" de la Iglesia que, en los últimos días, se preocuparon por el accionar violento de sectores piqueteros y acusaron al Gobierno de... 
27/08/04 | El Gobierno comenzó a desplegar una estrategia de acercamiento a la Iglesia Católica a raíz de los roces que sufrió la relación en los últimos meses. Por lo pronto, la Casa Rosada anunció ayer que el presidente Néstor Kirchner recibirá finalmente el...

Otros contenidos específicos se relacionaban con el debate de la Ley de Educación Sexual, las oposiciones e impugnaciones públicas de la Iglesia Católica argentina, y su sanción legislativa tanto a nivel nacional como en la Ciudad de Buenos Aires; la polémica por la muestra artística de León Ferrari, el caso Baseotto. En 2005 hubo declaraciones de Bergoglio a la prensa por la llamada tragedia de Cromañon, la salud de Juan Pablo II, su muerte y el cónclave de cardenales para la sucesión papal.

Como hemos señalado para otras palabras clave y noticias, Clarín y CL.COM publican informaciones en las que los títulos plantean ciertos temas y el medio espera las repercusiones. Esta modalidad "autorreferencial" (en el sentido de Luhmann, 2001) se acentúa con los diarios digitales, si bien forma parte de una estrategia de los medios para producir la continuidad informativa bajo la forma de declaraciones de los actores sociales y al reconvertir esas respuestas en una "nueva" noticia (Gomis, 1991).

Así la información vuelve a publicarse como noticia cuando muchas veces es el resultado de la acción del medio en el espacio público mediatizado. Veamos como ejemplo de esa dinámica las siguientes notas:

\section{En medio de la interna, Duhalde se juntó con Lavagna}

\section{y Bergoglio}

17/06/05 | El ministro de Economía, Roberto Lavagna, y el ex presidente Eduardo Duhalde se reunieron ayer a la mañana, para muchos en forma sorpresiva, en el Palacio de Hacienda. El encuentro, cuyo contenido fue manejado con total hermetismo, disparó...

\section{Se le escuchó a Kirchner: "No voy a firmar otro Pacto} de Olivos"

17/06/05 | Yo no voy a firmar un Pacto de Olivos con Duhalde". La sentencia se escuchó ayer en el despacho presidencial, donde Néstor Kirchner parece estar poniendo finalmente una lápida sobre la última posibilidad de acuerdo con Eduardo Duhalde. La relación...

POLITICA | VIII JORNADAS DE LA PASTORAL SOCIAL DE LA IGLESIA CATOLICA

\section{Bergoglio: "El internismo político es la gran enfermedad del país"}

25/06/05 | A poco de arrancar la carrera con vistas a los comicios de octubre, el arzobispo de Buenos Aires, cardenal Jorge Bergoglio, salió ayer a reivindicar con fuerza la actividad política. Pero alertó contra "el pensamiento único", el "creer que todo... 
En esta dinámica, la noticia resulta más bien una "profecía auto-cumplida" (Verón, 2001: $73^{119}$ ) antes que una novedad del acontecer social en su pasaje informativo a los medios.

Estos efectos de autorrepresentación (Marin, [1977] 2015: 57-58) y autorreferencia se encontrarían en la base de la relación entre los dispositivos mediáticos y la relación de representación: "Este es uno de los efectos de circularidad de la máquina mediática, condenada como está a fabricar información incluso sobre sí misma" (Charaudeau, 2003: 28).

Clarín, especialmente, actúa como institución mediática al prever las acciones que puede generar la publicación de ciertas noticias y comentarios de las noticias, ya que se trata de un diario de referencia dominante en la prensa gráfica y digital en el sistema de medios nacional (Albornoz, 2006).

También es cierto que su legitimidad como medio de comunicación, que brinda un servicio de información pública, ha sido cada vez más cuestionada en tanto empresa periodística con posición monopólica por sus relaciones con el gobierno kirchnerista y con la sociedad civil por casos como el de Papel Prensa, la adopción irregular de los hijos de la directora del diario, Ernestina Herrera de Noble, los problemas para la afiliación sindical en el Grupo Clarín, su oposición a la Ley 26522 de Servicios de Comunicación Audiovisual, llamada Ley de Medios, entre otros.

En La Nación y LN.COM, la palabra clave Bergoglio aparece asociada a noticias en las que la figura del líder religioso es construida como representación de un actor social que con voz de autoridad declama lo que hay que hacer, por encima incluso de los actores políticos del gobierno y de la oposición.

La Nación y LN.COM construyen una figura de Bergoglio que convoca y arbitra entre las partes con superioridad y legitimidad espiritual:

\section{Los obispos criticaron a la clase dirigente}

El cardenal Bergoglio presidió en la Catedral la misa crismal 25.05.2001 | $\underline{\text { La Nación }}$

Esta construcción representacional proviene de comienzos de la crisis de 2001, por el papel que asumió la Iglesia Católica argentina en la Mesa de Diálogo, y conecta con su

\footnotetext{
${ }^{119}$ Este autor cita a Gregory Bateson en Pasos para la ecología de la mente, pero al menos en esa obrael original en inglés- no figura el término "self-fulfilling prophecy".
} 
posición histórica en la Argentina y en América Latina como decíamos al comienzo de este capítulo: una representación monopólica en la gestión de las creencias religiosas (Mallimaci, 1996) que proviene de la época colonialista por la que la institución católica, muchas veces para justificar sus privilegios frente a otros cultos, se presenta como preexistente incluso a la nación argentina (Zanatta, 1996; Mallimaci, 1993; Esquivel, 2004, 2008).

El rol de liderazgo de la Iglesia Católica argentina que asumió Bergoglio a lo largo de la década de 2000 le permitió acceder al rango de cardenal y luego a candidato papable, lo que se concretó en 2013 al ser elegido sumo pontífice.

En LN.com, la presencia de la representación de la voz religiosa se encuentra incluso en la publicación de los sermones utilizados por Bergoglio en la liturgia (http://www.lanacion.com.ar/401649-texto-completo-de-la-homilia-de-corpus-christi):

\section{$\underline{\text { Texto completo de la homilía de Corpus Christi }}$}

...corazón las palabras de su Hijo: "hagan esto en memoria mía". Buenos Aires $1^{\circ}$ de junio de 2002

Card. Jorge Mario Bergoglio, s.j.

01.06.2002 | 05:15 | Cultura $\mid \underline{\text { lanacion.com }}$

En columnas y notas de opinión, como la que debajo firma Marcos Aguinis, Bergoglio es citado por el intelectual como una de las figuras destacadas en la información de actualidad argentina:

\footnotetext{
El cuento del tío

...muy costoso. Los buenos políticos, como los buenos jueces, son víctimas o prisioneros de los malos. El cardenal Jorge Bergoglio sugirió el parecido que tienen con los buitres. Se basó en la lectura sobre las aves voraces que el patriarca Abraham...

27.03.2001 | Opinión | Edición impresa
}

Los contenidos específicos sobre la pobreza, la inseguridad, las relaciones políticas con el gobierno y el Estado, entre otros tópicos, aparecen con frecuencia en relación a la figura de Bergoglio en La Nación y LN.COM, ya sea por su rol institucional o por su figura pública personal:

\section{La Conferencia Episcopal presentó un nuevo documento}

Los prelados despliegan una serie de propuestas donde plantean "la erradicación de la pobreza y la exclusión" como "el objetivo principal". (TN) 


\subsubsection{8 | Actualidad | lanacion.com}

\section{Bergoglio pidió una actitud de grandeza a los dirigentes}

El arzobispo de Buenos Aires leyó un documento que el Episcopado elaboró en marzo último (Gentileza América)

25.05.2010 | Actualidad | lanacion.com

El diálogo interreligioso, la condena del "clientelismo" político ${ }^{120}$, son otros de los contenidos específicos que agrupan los motivos temáticos presentes en esta palabra clave de la información de actualidad sobre fenómenos de religiosidad y que construye esa crítica admonitoria, dirigida al poder político, de la que hablábamos antes.

En Página/12 y P12.COM los contenidos específicos de la palabra clave 'Bergoglio', en orden cronológico ascendente, fueron: la crisis de finales de 2001, las declaraciones de Juan Pablo II por la situación social luego de la crisis, las noticias sobre la Mesa del Diálogo Argentino convocada por la Iglesia Católica, el Tedeum de 2002, el caso Storni, las primeras menciones de Bergoglio como candidato papable, la designación de Carmen Argibay en la Corte Suprema, el proyecto de ley de educación sexual tanto nacional como de la ciudad de Buenos Aires cuestionado por Bergoglio y Aguer en 2004, las noticias sobre la muestra de León Ferrari, el caso Baseotto en 2005, la elección de Benedicto XVI, el caso Maccarone, las marchas contra la inseguridad convocadas desde 2004 por Juan Carlos Blumberg, la relación conflictiva entre el Episcopado católico argentino y el gobierno en 2006, el homenaje al obispo Angelelli por los 30 años de su asesinato, la cumbre de obispos latinoamericanos en la reunión CELAM 2007 en Brasil, las elecciones por la presidencia argentina de 2007, el juicio al capellán genocida Von Wernich, el conflicto entre el gobierno y el sector agropecuario en 2008 , el $30^{\circ}$ aniversario de la mediación del cardenal Samoré entre Argentina y Chile, las declaraciones de Benedicto XVI en 2009 sobre la pobreza en la Argentina, el Bicentenario de la Revolución de Mayo en 2010, el debate y sanción de la Ley conocida como de Matrimonio Igualitario, las declaraciones judiciales de Bergoglio en la causa por las desapariciones en la ESMA.

Lo que destaca en P12 y P12.COM es el tono crítico respecto a la Iglesia Católica en general y en particular a sus autoridades y sectores conservadores. Uno de los periodistas especializados en la cobertura informativa sobre el catolicismo argentino

\footnotetext{
${ }^{120}$ En el capítulo sobre Asistencia social y pobreza de esta tesis discutimos las relaciones que en los medios indagados tiene el concepto de clientelismo con la religión, en especial en el caso de Cáritas.
} 
es Horacio Verbitsky, quien publicó notas sobre distintos aspectos de la figura de Bergoglio en el entramado de la Iglesia Católica argentina:

\section{PAPABILIDADES}

El eventual papa argentino que mencionan especialistas y agencias noticiosas volcaría todo el peso del Vaticano en contra de la revisión de los crímenes de la dictadura. Bergoglio es la personalidad más avasalladora y conflictiva de la Iglesia argentina en décadas, amado y execrado por igual, como testimonia la dividida Compañía de Jesús. El secuestro de cuatro sacerdotes, la distinción académica a Massera y los manejos económicos de la USAL. ¿Es posible un Pontífice de Guardia de Hierro?

PRINCIPAL |EI país |묘 |Domingo, 10 de abril de 2005

\section{BENDITOS SOBRESUELDOS}

Los obispos de confianza de Menem también cobraron sobresueldos, que obraron milagros. Interior los pagó con Aportes del Tesoro Nacional, concebidos para paliar desequilibrios transitorios de las provincias. José Luis Manzano puso a los obispos en la lista, práctica que continuaron Beliz, Rückauf y Corach, hasta cubrir 29 millones de pesos. Esto fue al margen de los pagos legales de la Cancillería por el culto, de las provincias por los colegios y de otros aportes negros de SIDE y Presidencia.

PRINCIPAL |EI país |ㅛㅛ |Domingo, 15 de mayo de 2005

\section{SEPULCROS BLANQUEADOS}

Bergoglio inició la canonización de los palotinos asesinados en 1976. El cardenal necesita blanquear su historia con vistas a una hipotética sucesión papal. Documentos de las cancillerías argentina y norteamericana y la propia investigación del Episcopado y el Vaticano muestran que el crimen fue obra de la dictadura. Sin embargo, la Iglesia eligió callarlo. Paulo VI se entrevistó con Massera, quien fue recibido con honores en dos universidades jesuitas, cuando Bergoglio era el Superior de la Orden.

PRINCIPAL |EI país 国 |Domingo, 31 de julio de 2005

Para Verbitsky, Bergoglio es un "conservador populista" aunque la ironía que implica este oxímoron, es decir, la contradicción en los términos, y otros juegos de sentido son frecuentes en las adjetivaciones que el periodista realiza en sus notas de Página/12 que, además, refuerzan el estilo del medio:

\section{FLORES DEL MAL}

Dos coaliciones antagónicas quedaron delineadas esta semana. La ceremonia sadomasoquista de la Catedral sugiere que sólo Bergoglio puede conferir eficacia política a las insatisfacciones corporativas que se oponen al gobierno. Pero el conservador populista que conduce la Iglesia no lo hace en nombre del poder económico o militar sino invocando a los pobres y a los que tienen hambre y sed de justicia. Otro dato que refuerza la urgencia política de la redistribución de la riqueza.

PRINCIPAL |티 país [ㅛㅛ |Domingo, 28 de mayo de 2006

En algunas notas, entrevistas o noticias, P12 y P12.COM destacan a los líderes religiosos que realizan planteos progresistas, ya sean tanto católicos, judíos o de otras confesiones religiosas: 


\section{"LA POLÍTICA ES UNA CALESITA EN LA QUE LA SORTIJA LA SACAN SIEMPRE LOS MISMOS"}

Lo dijo el cardenal Jorge Bergoglio en su homilía de ayer. El arzobispo de Buenos Aires evitó referirse al caso Baseotto, pero su vocero remarcó que "no está dicha la última palabra".

PRINCIPAL |EI país |⿴囗玉 |Viernes, 25 de marzo de 2005

En cuanto a las relaciones entre el gobierno y la Iglesia Católica argentina, Bergoglio fue una de sus figuras protagonistas. En el año electoral de 2007, P12 y P12.COM dedicaron varias notas a este tópico, entre otras:

\section{CARRIÓ, LA PRIMERA DEL REBAÑO}

El ministro del Interior, Aníbal Fernández, bajó el tono a la discusión con Bergoglio. La líder del ARI respaldó al cardenal, quien había asegurado que la Iglesia "fue, es y será perseguida".

PRINCIPAL |El país [표 |Miércoles, 25 de abril de 2007

\section{BERGOGLIO HABLÓ DE "PERSECUCIÓN" Y KIRCHNER, DE "DAR LA OTRA MEJILLA"}

El cardenal Jorge Bergoglio hizo referencia al martirio de Esteban, al abrir la asamblea de la Conferencia Episcopal. El Presidente usó la frase bíblica al referirse a la oposición.

PRINCIPAL |EI país 国 |Martes, 24 de abril de 2007

EN GOBIERNO LO ACUSAN DE "ARIETE DE LA OPOSICION"

\section{REFLEXIÓN ECLESIAL Y ELECCIONES}

PRINCIPAL IEl país |subnota |Martes, 24 de abril de 2007

\section{CON LAS ELECCIONES COMO TELÓN}

> Por Washington Uranga

PRINCIPAL |EI país |Lunes, 23 de abril de 2007

LA COMPLICADA RELACION DEL KIRCHNERISMO CON LA IGLESIA CATOLICA

\section{BASEOTTO, LA PIEDRA DE LA DISCORDIA}

PRINCIPAL |EI país |subnota |Jueves, 20 de diciembre de 2007

Por lo que decíamos anteriormente, la consideración de Casaretto en el ala "progresista" de la Iglesia Católica lo acerca al estilo de Página/12. Casaretto es uno de los líderes religiosos nacionales de la Iglesia Católica a quien se lo considera principal promotor del sector progresista junto con su mentor Justo Laguna y otros líderes religiosos anteriores (http://www.lanacion.com.ar/1485460-casaretto-reemplazara-a-bargallo).

$\mathrm{Su}$ perfil se hizo muy visible en los medios cuando asumió la presidencia de Caritas y de la Comisión Episcopal de Pastoral Social y se dedicó a puntualizar los 
temas conflictivos de la pobreza, las drogas y a denunciar la proliferación de casinos y salas de juego que se multiplicaron en el interior del país.

En 2009 la temática de la pobreza ganó espacio en los medios nacionales por las declaraciones del Papa Benedicto XVI que clarín.com publicó y orientó como declaraciones que se relacionaban con nuestro país (en el apartado $\mathbf{5 . 6}$ explicamos en detalle esa operatoria):

\section{POLITICA | DESPUES DE QUE EL TITULAR DE LA PASTORAL SOCIAL ANTICIPO A CLARIN QUE RONDA EL 40 POR CIENTO \\ El Papa pidió reducir en el país el "escándalo de la pobreza" \\ 06/08/09 | La campaña de la Iglesia para instalar como tema prioritario tras las elecciones el combate a la pobreza recibió ayer un fuerte impulso que sacudió el tablero político. Nada menos que el Papa Benedicto XVI -aprovechando su habitual mensaje con...}

Otro de los temas que contiene la palabra clave Casaretto fue el pedido de diálogo, publicado como noticia en clarín.com, a las autoridades del gobierno y de la oposición política en 2008 en el contexto de lo que se llamó la 'crisis del campo', CL.COM publicaba:

POLITICA | EL TITULAR DE LA PASTORAL SOCIAL, EN UN DESAYUNO CON EMPRESARIOS

\section{Casaretto dijo que la Iglesia quiere ayudar pero no la dejan \\ 14/07/08 | Sea porque el momento actual deja poco margen para las abstracciones. Sea porque no fue una charla abierta, sino para dirigentes políticos, empresarios, diplomáticos y académicos. O por una mezcla de las dos. Lo cierto es que la primera espada de la...}

El conflicto del gobierno con el sector agropecuario durante 2008, la inflación y la corrupción aparecieron en menor medida en las noticias tratadas por los medios y relacionadas con la palabra clave Casaretto.

Una de las diferencias llamativas es que en LN.COM, Caritas tuvo espacio entre las noticias de 2001 a 2003 por su participación en la Mesa del Diálogo Argentino y en la organización de eventos solidarios por la crisis de 2001. En cambio, en P12.COM fue frecuente que el nombre de Casaretto aparezca en los titulares y se publicaran declaraciones y reportajes a este religioso.

La Conferencia Episcopal Argentina (CEA) fue dirigida desde 1999 hasta 2002 por quien fuera arzobispo de Paraná y luego cardenal, Estanislao Karlic; de 2002 a 2005 
por Eduardo Mirás y conducida por Jorge Bergoglio desde 2005 a 2008 y de 2008 a 2011.

De manera frecuente en nuestro período 2001-2010, la CEA hizo declaraciones políticas sobre: la pobreza, la pérdida de fieles, el matrimonio igualitario, la corrupción, el conflicto entre el sector agropecuario y el gobierno, el Estado, la asistencia social, la educación sexual, el caso del ex vicario castrense Baseotto, el caso Von Wernich (el religioso condenado por la justicia por violaciones a los derechos humanos en la última dictadura cívico-militar argentina), el aborto, el caso Angelelli, el conflicto con Uruguay por la papelera Botnia, que fueron retomadas y construidas como noticias en los medios indagados.

El contenido temático de las noticias sobre política y religión es similar en los tres medios observados. Su tratamiento en relación al Episcopado católico argentino difiere en las posiciones enunciativas respectivas al estilo de cada medio: a grandes rasgos, una enunciación distanciada en el caso de Clarín y CL.COM, interpretativa en La Nación y LN.COM, de oposición crítica en Página/12 y P12.COM.

La presencia de otros cultos, además del católico, entre las noticias sobre política y religión indica que los evangélicos tienen una visibilidad cada vez mayor a partir de su participación, ya sea en alianzas interreligiosas o de manera diferenciada, como sucedió en los proyectos de ley de libertad e igualdad religiosa.

Sin embargo, el período 2001-2010 se percibe signado por una fuerte hegemonía de la presencia pública del catolicismo argentino que reformuló la visibilidad sobre su participación pública durante la década de 1990 y la reconvirtió, otra vez con éxito, en su habitual papel de "reserva moral de la nación" con la crisis de 2001 en continuidad con sus momentos de mayor esplendor durante el siglo XX.

\subsection{Vaticano}

Entre los principales contenidos temáticos de las noticias de esta palabra clave en el período 2001-2010 destaca, por una parte, la muerte de Juan Pablo II y, el cónclave de la elección papal de 2005 que coronó a Benedicto XVI como sucesor y sumo pontífice. Si bien su renuncia y la posterior elección de Bergoglio como Francisco 
I en 2013 no forman parte de nuestro objeto de estudio, ya que este abarca hasta $2010^{121}$.

En este sentido, en las noticias previas y posteriores a la muerte de Juan Pablo II durante 2005 pudimos observar las menciones al entonces cardenal Bergoglio como uno de los posibles candidatos a sucederlo y, luego, en la publicación de notas periodísticas sobre la importante cantidad de votos que había logrado en el cónclave. Sin embargo, muchas informaciones descartaban la posibilidad de que fuera elegido por lo difícil que resultaba que un jesuita latinoamericano pudiera ocupar la cátedra de San Pedro.

Otros contenidos temáticos también se hicieron presentes en el corpus de noticias de diarios digitales e impresos: el papado y la muerte de Juan Pablo II, la pedofilia en la Iglesia Católica, los cónclaves y la política vaticana, el nombramiento de cardenales, la discusión y las posibles reformas doctrinarias en el catolicismo.

En clarín.com se destacaban las menciones a Bergoglio en los títulos y en noticias sobre el Vaticano, el matrimonio igualitario y en las informaciones acerca de las tensiones políticas con el gobierno, el Te Deum y la pedofilia.

Lanacion.com centró sus notas en la relación entre los cardenales y el Papa; en cambio, pagina12.com acentuaba los contenidos temáticos de la pedofilia en la Iglesia Católica, el conservadorismo de Benedicto XVI y las notas frecuentes de Horacio Verbitsky sobre la complicidad de la Iglesia Católica argentina durante la última dictadura militar. En pagina12.com son frecuentes las notas sobre derechos sexuales y reproductivos de mujeres y minorías sociales.

Ahora observaremos las noticias de la dimensión de análisis relativa al Vaticano en cada uno de los medios indagados, dada la extensión del corpus, en orden temporal descendente.

\section{CLARÍN Y CL.COM}

\footnotetext{
${ }^{121}$ Sin embargo, la elección del primer Papa latinoamericano cambió las condiciones de observación del análisis en cuanto ese acontecimiento modificó el modo en que observamos las relaciones previas de causalidad. Ahora otorgamos relevancia a ciertas noticias por la figura de Bergoglio, analizamos las estrategias y alianzas que actúan de forma inevitable en las condiciones de observación de las noticias del período. Podríamos decir que siempre sucede así pues la Historia no es contrafáctica, pero tampoco deja de ser cierto que todavía hay repercusiones mediáticas o extramediáticas por la elección de Bergoglio como primer Papa latinoamericano y la significación excepcional que tuvo para nuestro país. Por otra parte, el marco teórico que sostenemos con Peirce (1955 [1905]) postula que la semiosis, es decir, el conjunto de las significaciones sociales se encuentran en un proceso dinámico, donde los signos se conectan hacia el pasado y hacia el futuro. En el análisis de las significaciones esas fuerzas indiciales de los signos pueden revertirse (Verón, 1987, 1993, 2013).
} 
En 2010 varias noticias relacionadas con los casos de pedofilia cometidos por sacerdotes de la Iglesia Católica fueron publicadas por este medio con el calificativo de “escándalos” en títulos, subtítulos y volantas, que referían al Vaticano y a Benedicto XVI:

MUNDO | LOS ESCANDALOS QUE SACUDIERON A LA IGLESIA CATOLICA

\section{Dura condena del Papa a los curas abusadores de}

\section{menores}

21/12/10 | Sin ocultar su gran conmoción, el Papa dedicó ayer el núcleo central de su discurso a los cardenales y otros altos prelados de la Curia Romana (el gobierno central de la Iglesia) a la más dura condena de los abusos sexuales de menores por parte de...

MUNDO | CRITICA VISION DE LA EMBAJADA ESTADOUNIDENSE SOBRE UN ESCANDALO CLAVE EN LA IGLESIA

\section{Revelan que el Vaticano presionó a Irlanda por los} curas pedófilos

12/12/10 | Desbordó el río Tíber y embistió al Vaticano la avalancha Wikileaks, con las revelaciones de miles de cables diplomáticos norteamericanos. Son centenares de despachos reservados y secretos, convertidos en un cóctel explosivo de "extrema gravedad"...

MUNDO

\section{El Papa analiza junto a cardenales de todo el mundo el escándalo por pedofilia en la Iglesia}

19/11/10 | Ciento cincuenta cardenales de todo el mundo se encuentran reunidos hoy con el Papa Benedicto XVI en el Vaticano para "reflexionar" sobre los casos de pedofilia cometidos por miembros de la Iglesia, entre otros temas religiosos. La reunión se...

La clasificación de estas noticias en la sección "Mundo" indicaba el carácter internacional de la información, por encima del carácter delictivo, que lo habría ubicado en la sección policial.

Algunos rasgos del género periodismo de investigación aparecían en referencias a las filtraciones de información confidencial en internet a través del sistema creado por Julian Assange conocido como Wikileaks, en particular, aquellas que involucraron al Vaticano, llamadas por eso Vatileaks.

En ese año CL y CL.COM también publicaron noticias sobre el debate y la sanción de la Ley 26.618 conocida como ley de matrimonio igualitario:

\section{Intenso debate en el interior de la Iglesia}

18/07/10 | Un fuerte debate interno se desató en la Iglesia luego de que el Senado convirtió en ley el proyecto de matrimonio gay. Su eje pasa por la estrategia que siguió el Episcopado -o sea, el centenar de obispos del país- de salir a jugar fuerte a través... 
18/07/10 | ¿Cómo evalúa la aprobación en el Senado del matrimonio gay? Es el resultado del apuro y de una imposición ideológica. Subsisten los problemas señalados por especialistas de todas las disciplinas en audiencias del Senado. En el fondo, hay un...

\section{SOCIEDAD | SESION HISTORICA}

\section{El Senado convirtió en ley el matrimonio homosexual}

15/07/10 | En una sesión histórica, dominada por la expectativa sobre el resultado hasta el momento de la votación, el Senado aprobó esta madrugada el proyecto que avala el matrimonio gay. De esta forma, la Argentina se convirtió en el primer país de...

\section{SOCIEDAD}

\section{Duros discursos y extensas argumentaciones a favor y} en contra del matrimonio gay

15/07/10 | Entre largos y argumentativos discursos, ya comienzan a perfilarse algunas proyecciones en el debate sobre la ley de matrimonio gay en el Senado. El sorpresivo vuelco de los oficialistas Luis Vianna y Daniel Pérsico, quienes se esperaba que votaran...

\section{La Iglesia puso todo en juego}

14/07/10 | Si se considera que no es fácil en la actualidad convocar gente en las calles, puede concluirse que la manifestación de anoche contra el matrimonio gay frente al Congreso tuvo una importante concurrencia. Si se piensa en la cantidad de personas que...

\section{Los Kirchner ponen de nuevo en juego la fórmula del} "todo o nada"

14/07/10 | Hay una batalla pública que Cristina y Néstor Kirchner van ganando, más allá de los réditos políticos que esa misma batalla pueda traducirles en los futuros tiempos electorales. El matrimonio no sólo tiene la virtud de atizar temas de debate, muchas...

\section{SOCIEDAD}

\section{Fue masiva la movilización de agrupaciones religiosas contra el matrimonio gay}

13/07/10 | Convocados por organizaciones católicas, evangélicas y multirreligiosas, militantes en contra del proyecto que discutirá mañana el Senado y que propone legalizar el matrimonio entre personas del mismo sexo se concentraron esta noche en forma masiva...

En 2009, como hemos señalado en los apartados anteriores, Bergoglio había intentado que tanto Scioli como gobernador de la provincia de Buenos Aires - a través de Aguercomo Macri, jefe de gobierno porteño, apelaran el fallo judicial por los primeros casamientos entre personas del mismo sexo:

\section{SOCIEDAD | LA IGLESIA INTENTARA FRENARLO EN LA JUSTICIA \\ Dura crítica de Bergoglio a Macri por no apelar el matrimonio gay}

24/11/09 | El jefe de Gobierno porteño, Mauricio Macri, no consiguió ayer un acercamiento con el arzobispo de Buenos Aires, cardenal Jorge Bergolio, luego de que éste lo criticara por no apelar el fallo que hizo lugar a un pedido de casamiento de una pareja de... 


\section{El cardenal Bergoglio le recriminó a Macri su apoyo al}

\section{matrimonio gay}

24/11/09 | La cúpula de la Iglesia Católica, encabezada por el arzobispo de Buenos Aires, cardenal Jorge Bergoglio, se reunió este mediodía con el jefe de Gobierno porteño, Mauricio Macri. Hubo varios temas de agenda, como la pobreza, pero también una...

Con anterioridad, desde 2004 aproximadamente, hubo varias notas sobre las relaciones “tensas" entre el gobierno kirchnerista y la Iglesia Católica argentina. Sin embargo, el Episcopado católico repetía una de sus estrategias institucionales de "hegemonización" (Soneira, 1989; Ameigeiras, 2008; Esquivel, 2008, 2004) al arrogarse la representación general de las religiones en el debate por el matrimonio igualitario.

Pese a que algunos cultos no se opusieron a la sanción de la ley (por ejemplo, las iglesias protestantes históricas nucleadas en la Federación Argentina de Iglesias Evangélicas [FAIE], las iglesias luteranas, la Iglesia Metodista, la Iglesia Presbiteriana), la Iglesia Católica argentina se presentaba en representación de 'todos' los sectores religiosos cuando sólo era una 'parte' e incluso, para algunos, minoritaria en cuanto a la cantidad de fieles que convocaba ${ }^{122}$.

Una alianza interconfesional entre los sectores conservadores del catolicismo, del judaísmo y de algunos grupos evangélicos estuvo en contra del debate y la sanción de la ley de matrimonio igualitario para personas del mismo sexo.

En el sector de los evangélicos pentecostales estuvieron reunidos en la Federación Confraternidad Evangélica Pentecostal (FECEP) y en la federación Alianza Cristiana de Iglesias Evangélicas de la República Argentina (ACIERA), representados por Cinthya Hotton, junto a la Iglesia Católica argentina con el cardenal Bergoglio al frente de la Conferencia Episcopal Argentina (CEA).

Por más que algunas organizaciones y sacerdotes católicos se pronunciaron a favor de la ampliación de derechos civiles, estos sectores quedaron con poca visibilidad mediática. A su vez, CL y CL.COM presentaban las noticias relativas a estos acontecimientos en las secciones Sociedad, Editorial u otras, pero omitían clasificarlas bajo el título de Política.

\footnotetext{
${ }^{122}$ Esta operatoria que llamamos de "hegemonización" pervive desde el momento en que el catolicismo busca que se la considere 'la Iglesia' por antonomasia y tiene explicación en el devenir histórico, por su rol en nuestro país (Mallimaci, 1988, 1993, 2015; Esquivel, 2004, 2008).
} 
También respecto del Tedeum de 2010, año del Bicentenario, las tensiones entre el gobierno y el Episcopado católico tuvieron varias informaciones publicadas en Clarín y CL.COM.

En uno de los subtítulos de las noticias, este medio clasificaba y calificaba “Tedeum K". Esta modalidad le permitía establecer diferenciaciones entre dos supuestos tedeum, uno a favor del gobierno y otro en contra, así como ubicaba a la conducción de la Iglesia Católica argentina como parte de la oposición política al gobierno.

La figura principal en esas noticias era la del entonces cardenal Bergoglio:

OPINIÓN | EDITORIAL

\section{El mensaje de la Iglesia a la política}

29/05/10 | En las homilías centrales del 25 de Mayo, dos principales dignatarios de la Iglesia, el cardenal primado Jorge Bergoglio y el arzobispo Agustín Radrizzani, coincidieron en el llamado a superar la confrontación permanente y mejorar la calidad de...

POLÍTICA

\section{Ante Cristina, la Iglesia pidió "mayor independencia de los poderes" \\ $\mathbf{2 6 / 0 5 / 1 0 ~ | ~ T e d e u m ~ K ~ e n ~ L u j a ́ n . ~ L a s ~ b a n d e r a s ~ k i r c h n e r i s t a s ~ q u e ~ n o ~ s e ~ h a b i ́ a n ~ v i s t o ~ d u r a n t e ~ l a ~}$ celebración de estos días en la 9 de Julio aparecieron todas juntas ayer frente a la Basílica de Luján. Desde temprano, coparon la plaza pancartas con los nombres de la... \\ POLITICA}

\section{Frente a parte de la oposición, Bergoglio llamó a la unidad \\ 26/05/10 | El perfume opositor se sentía, es cierto, pero no fue tan intenso ni más allá de lo políticamente aconsejable para la fecha. Más bien, se vio voluntad de no agudizar el enfrentamiento con la Casa Rosada. Los opositores que fueron a escuchar la...}

POLITICA | LA PATRIA CUMPLE 200 AÑOS: LOS FESTEJOS RELIGIOSOS DEL 25 DE MAYO TAMBIEN GENERAN POLEMICA

\section{Gobierno y oposición, separados en los Tedeum del Bicentenario}

25/05/10 | Con una hora de diferencia, y a poco más de 60 kilómetros de distancia, el Tedeum oficial y el que dará el cardenal Jorge Bergoglio en la ciudad de Buenos Aires funcionarán como otra secuencia de los cruces políticos en el marco de la conmemoración...

GOBIERNO

\section{Bergoglio ofició el Tedeum en la Catedral: El país "merece un clima social y espiritual distinto"}

25/05/10 | El cardenal Jorge Bergoglio encabezó el Tedeum en la Catedral Metropolitana haciendo un fuerte llamado a la unidad y a la grandeza de los argentinos, en especial de sus dirigentes. Y comenzó la ceremonia saludando a quienes participan del otro...

POLÍTICA

\section{Antecedentes}

18/05/10 | En el 2003, apenas asumió, Néstor Kirchner asistió al Tedeum que el cardenal Bergoglio celebró, como es tradición, en la Catedral. Lo mismo hizo en el 2004. Bergoglio advirtió contra la intolerancia. Fue el último oficio patrio en Buenos... 
En 2009 hubo algunas noticias sobre la beatificación de Juan Pablo II:

EL MUNDO | EL 17 DE OCTUBRE DE 2010 SERA BEATIFICADO

\section{Juan Pablo II, más cerca de ser proclamado santo}

19/11/09 | Hay una fecha tentativa para la beatificación de Juan Pablo II: el domingo 17 de octubre, una jornada cargada de significados para la historia de los argentinos. Pero este 17 de octubre será el de 2010 y no el de 1945. Clarín hace diez días fue el...

Las declaraciones de Benedicto XVI acerca de la pobreza en Latinoamérica, como ya hemos señalado, tuvieron mucha repercusión en los medios argentinos. Tanto CL y CL.COM como LN y LN.COM las recontextualizaron como referencias que el líder religioso realizaba sólo en relación con la Argentina. Lo que en apariencia permitía la relación de referencia que hacían los diarios digitales era que en nuestro país se estaba llevando a cabo la colecta Más por menos:

POLÍTICA | DESPUES DE QUE EL TITULAR DE LA PASTORAL SOCIAL ANTICIPO A CLARIN QUE RONDA EL 40 POR CIENTO

\section{El Papa pidió reducir en el país el "escándalo de la pobreza"}

06/08/09 | La campaña de la Iglesia para instalar como tema prioritario tras las elecciones el combate a la pobreza recibió ayer un fuerte impulso que sacudió el tablero político. Nada menos que el Papa Benedicto XVI -aprovechando su habitual mensaje con...

En el cuerpo del texto de esta última nota se señala que: "Por lo pronto, Kirchner reafirmó que la pobreza "ronda el 22 ó 23 \%", contra el "casi 40 \%" que manejan los obispos en base a las mediciones que está procesando el Observatorio Social de la Universidad Católica”. Estas cifras contradecían los índices oficiales del Indec y otras mediciones efectuadas:

\section{Como el Papa, Bergoglio sostuvo que la pobreza es "escandalosa" \\ 07/08/09 | La Iglesia aprovechó la popular festividad del patrono del pan y del trabajo, San Cayetano, para insistir en la gravedad de la pobreza y la necesidad de aunar esfuerzos para combatirla. Fue así que -en línea con las afirmaciones del Papa, conocidas...}

La observación de la cronología de las noticias demuestra que esas palabras acerca del "escándalo de la pobreza" eran una insistencia del Episcopado católico argentino desde 2008: Clarín y CL.COM ya las habían publicado como declaraciones del sumo pontífice. 
Así este medio repetía otra de sus estrategias mediáticas institucionales, la capacidad autorreferencial o de autorrepresentación -a la que que ya hemos hecho referencia hacia el final del apartado 5 de Educación sexual (supra)- en la imposición de la agenda temática de los medios nacionales.

Incluso habían elegido repetir el término "escándalo" con el que se presentaría la noticia en una estrategia de visibilidad pública y de construcción informativa compartida que, en nuestro período indagado, se repite tanto en CL y CL.COM de un modo similar al que observáramos en el caso del suplemento Valores Religiosos.

En el cuerpo del texto de la noticia también se publicó el recuadro de un analista que confundía la explicación, con el supuesto cuidado que habría tenido Bergoglio respecto de las declaraciones del Papa:

\begin{abstract}
Crítica que duele
Mariano Thieberger

La estructura jerárquica de la Iglesia Católica impide que un obispo pueda ir más allá de las palabras del Papa. Allí está la explicación del cuidado que exhibió ayer el cardenal Bergoglio al hablar de la situación social en la Argentina. Pero, un día antes, las palabras de Benedicto XVI habían generado tal impacto que tampoco hacía falta más. El debate sobre el número de pobres ya está instalado y promete perdurar un buen tiempo. Y son las críticas que más le duelen al Gobierno. Más que las que se escuchan sobre el INDEC, los superpoderes o los tarifazos.
\end{abstract}

El periodista especializado en noticias sobre religión, Sergio Rubín, encaraba la noticia de otro modo:

\title{
POLÍTICA | REUNION DE LA CUPULA DEL EPISCOPADO
}

\section{La pobreza ya ronda el $40 \%$, insiste la Iglesia}

$\mathbf{1 8 / 0 8 / 0 9}$ | La Iglesia sigue firme en su propósito de convertir al combate contra la pobreza en un tema central del Gobierno, la oposición y de todos los sectores de cara a la celebración del Bicentenario de la Argentina. En la primera jornada de la reunión de...

Desde un primer momento, el periodista le otorgaba en su nota cierta voluntad política a la Iglesia Católica en las palabras "insiste”, "sigue firme en su propósito". En el primer párrafo del texto de esta última nota decía:

\footnotetext{
La Iglesia sigue firme en su propósito de convertir al combate contra la pobreza en un tema central del Gobierno, la oposición y de todos los sectores de cara a la celebración del Bicentenario de la Argentina. (...) Si bien no se anticipó cuál podría ser, no se descarta que consista en un proyecto de universalización del subsidio para los menores pobres, que miembros de la oposición vienen impulsando, pero que el Gobierno rechaza.
}

El reclamo del Episcopado católico argentino que adelantaba Sergio Rubín, y que estaba en discusión, parecía apuntar a lo que después se llamó Asignación Universal por Hijo, que el gobierno implementaría recién en octubre de 2009. 
En la nota se explica por qué el Episcopado católico argentino insistía en la visibilización mediática del tema de la pobreza, más allá de las discusiones por las cifras:

\footnotetext{
Además, Oesterheld informó que el Episcopado decidió realizar en 2011 un Congreso sobre Doctrina Social para analizar el tema de la pobreza a la luz de las enseñanzas católicas. Y que, con vistas a ese encuentro, procurará ir creando un clima de preparación para que sea muy participativo y fructífero.

Es evidente que la Iglesia quiere mostrar que su preocupación por la pobreza no es coyuntural, además de asegurarse que -como lo dijo en un documento en 2008-figure en la agenda del Bicentenario (2010/2016).

Por lo demás, Oesterheld aclaró que la Iglesia "no quiere entrar en una polémica sobre las cifras de la pobreza porque, sea cual fuere (el porcentaje), igual es escandalosa". Pero subrayó que, sobre esa consideración, la posición de los obispos "es unánime", en consonancia con lo dicho por el Papa con motivo de la [colecta] Más por Menos del Episcopado, que se hará en setiembre. Benedicto XVI había denunciado días atrás "el escándalo de la pobreza" en el país, lo que suscitó un gran debate y una reacción por parte de funcionarios del Gobierno.

"Lo importante es tomar como eje el documento de la Iglesia del año pasado, donde se alentaba al diálogo y encontrar cuatro o cinco políticas de Estado para combatir la pobreza", dijo.
}

En esta última nota se hace patente la contradicción existente en afirmar que las declaraciones del Papa en 2009 precedieron a las preocupaciones de los obispos, cuando existía el documento del Episcopado argentino de 2008.

La publicación de las declaraciones de la Iglesia Católica argentina y, en particular del cardenal Bergoglio, podían parecer una reafirmación y relocalización en nuestro contexto de lo que había dicho Benedicto XVI acerca de la pobreza en uno de sus mensajes papales, y varias veces los medios lo presentaron así -al menos por economía en la sintaxis periodística de sus titulares.

Al revisar el orden y las fechas de publicación de las noticias se puede observar que el Episcopado católico argentino ya había advertido sobre la pobreza en el documento de diciembre de 2008. Incluso fue la misma institución la que elaboró los datos en la Universidad Católica Argentina y esta "advertencia” a los gobernantes sobre datos de la pobreza, desde 2008, continuó en todo el período.

\section{POLITICA I IMPACTO DEL MENSAJE SOBRE LA POBREZA \\ La Iglesia instaló un debate que puso en aprietos al oficialismo}


15/08/09 | Bastó que la Iglesia llamara la atención sobre el incremento del número de pobres en el país para que el tema volviera a convertirse en uno de los ejes centrales del debate político. Y pusiera en aprietos al oficialismo Un Obispo influyente como...

En el cuerpo del texto de esta última nota, el periodista Atilio Bleta hacía la cronología de lo ocurrido:

\begin{abstract}
Un Obispo influyente como monseñor José [Jorge] Pedro Casaretto advirtió el 19 de diciembre del año pasado que hay en el país un "recrudecimiento de la pobreza", al que no se veía desde principios de 2007. Dijo también que estamos en una situación de alerta y preocupación". El 14 de marzo de este año, el cardenal primado de la Argentina Jorge Bergoglio le entregó en Roma un documento al Papa que puso de relieve la preocupación por "el escándalo de la pobreza y la exclusión social".

Y Benedicto XVI, el jueves 7 de este mes, conmovió al Gobierno al llamar a "reducir el escándalo de la pobreza y la inequidad social". Las palabras del Papa son casi las mismas del documento de Bergoglio y se conocieron el día en que la Iglesia lanzó la tradicional colecta "Más por Menos", curiosa coincidencia que ayudó a instalar como prioritaria la discusión sobre el número de pobres.
\end{abstract}

Luego de un viaje del cardenal Bergoglio al Vaticano, en 2009, Benedicto XVI incluyó en uno de sus mensajes la referencia al "escándalo de la pobreza" y el Episcopado católico argentino. Junto con CL y CL.COM insistieron en que esas declaraciones referían a la Argentina.

Incluso Clarín y CL.COM utilizaban la misma palabra en referencia al otro escándalo, el de pedofilia que implicaba al Vaticano y que, según los medios, el gobierno recriminaba en declaraciones off the record que el Papa no condenara los escándalos del gobierno de Silvio Berlusconi en Italia. En definitiva, había acusaciones cruzadas de "escándalos" mutuos, al menos según los titulares de CL y CL.COM.

En el siguiente editorial, se justificó el mensaje papal y la preocupación de la conducción de la Iglesia Católica argentina, por "la crisis" y por la supuesta falta de estadísticas confiables:

\title{
La relación entre la pobreza y la credibilidad
}

08/08/09 | La discusión sobre la pobreza se ha instalado en la discusión económica y social como consecuencia de la crisis y de la falta de confiabilidad en las estadísticas oficiales, que minimizan el alcance de la pobreza real. La recuperación de esos... 
La argumentación que hace el editorial periodístico es la siguiente:

Estas expresiones están en línea con el mensaje tradicional de la Iglesia sobre los problemas sociales, aquí y en el resto del mundo. Sin embargo, en este caso, los mensajes resonaron con una intensidad especial y causaron preocupación en el Gobierno argentino, porque según las estadísticas oficiales, la pobreza, lejos de constituir un escándalo, viene reduciéndose desde 2003. Esta tendencia que no habría cesado a pesar de la caída del empleo y de los ingresos debidos a la crisis, y a fines de 2008 afectaría a un $15 \%$ de la población. Esta curiosidad se debe a que las estadísticas oficiales subestiman el incremento de los precios con los que se miden el valor de la canasta que determina el nivel de pobreza. Si esa canasta se evaluara tomando en cuenta la inflación que informan las evaluaciones privadas, o la que surge de organismos estadísticos provinciales que no modificaron sus sistemas de cálculo en los últimos dos años y medio, se encontraría que la pobreza comenzó a subir a partir de fines de 2006, y alcanzaría en la actualidad a un $30 \%$ de la población. Notablemente, el propio ex presidente Néstor Kirchner, bajo cuya administración comenzaron a alterarse los cálculos de los precios al consumidor, acaba de afirmar que la pobreza sería en la actualidad de un $20 \%$ o un $23 \%$.

En un destacado del texto, se resumía así:

El Papa y el cardenal Bergoglio se refirieron al escándalo de la pobreza en la Argentina, una preocupación habitual de la Iglesia. Causó preocupación oficial porque las estadísticas públicas no dan cuenta del nivel real de la misma. La distorsión de las estadísticas es causa de falta de credibilidad en la política oficial, lo cual retrasa la inversión necesaria para reactivar la economía y reducir la pobreza. (El subrayado es nuestro).

Es una argumentación lógica frecuente y habitual en el estilo de CL y CL.COM: bajo una aparente claridad y sencillez de lenguaje se mezclan las causas con las consecuencias, se reúnen a los actores políticos en el espacio imaginario del género editorial, según el cual, la preocupación del gobierno se debía a que las estadísticas públicas sobre pobreza no fueran veraces cuando era el gobierno mismo el que las elaboraba (véase el subrayado nuestro en el texto).

En cambio, según el editorial las estadísticas no oficiales sobre pobreza a las que se refería la Iglesia Católica argentina eran un producto de su propia universidad, la Universidad Católica Argentina (UCA), de gestión privada y perteneciente al culto católico. La relación establecida en la noticia entre pobreza y credibilidad es la que le 
permitía al medio periodístico criticar al gobierno kirchnerista y justificar los reclamos de la Iglesia Católica.

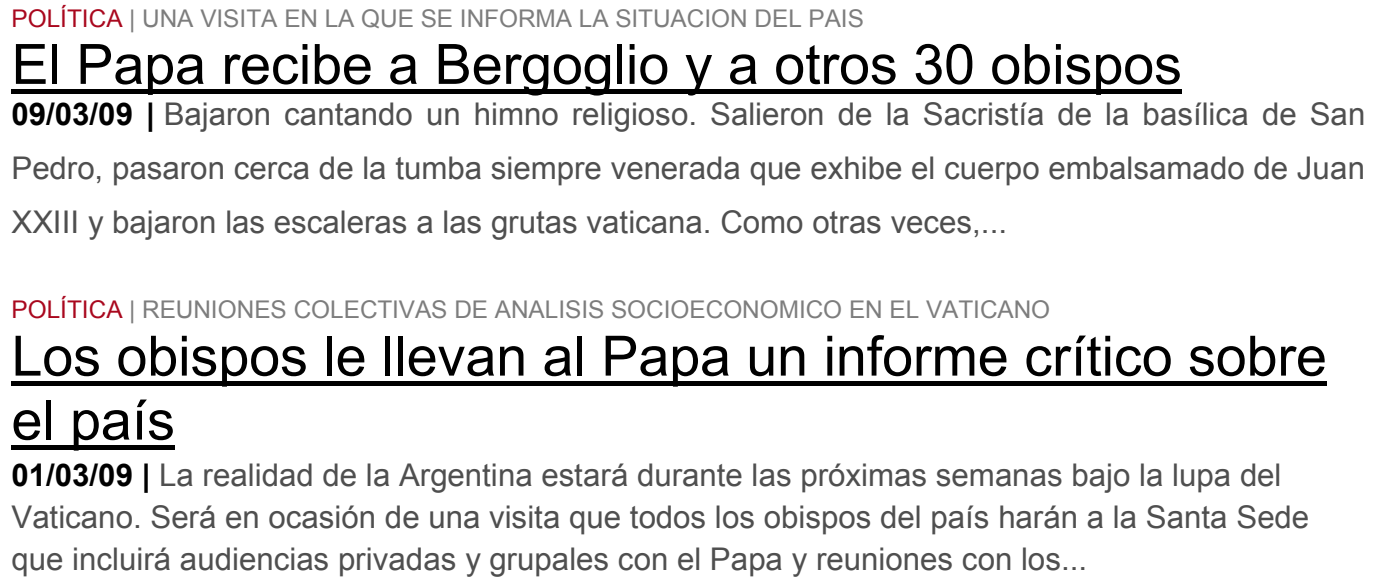

En 2009 hubo noticias sobre amenazas contra el sacerdote católico José María Di Paola, conocido como padre "Pepe" que trabajaba en villas de emergencia de la ciudad de Buenos Aires. Otra de las operatorias que observamos con frecuencia es el desplazamiento de ciertos nombres propios, en este caso del padre Pepe, y el protagonismo de otros líderes religiosos en los medios. El nombre de Bergoglio, por ejemplo, a diferencia de los de Casaretto y Aguer tuvo una visibilidad mucho mayor en títulos y subtítulos e incluso en el modo en que esos titulares eran construidos. En este caso, las amenazas al padre Pepe las hizo públicas y las denunció Bergoglio:

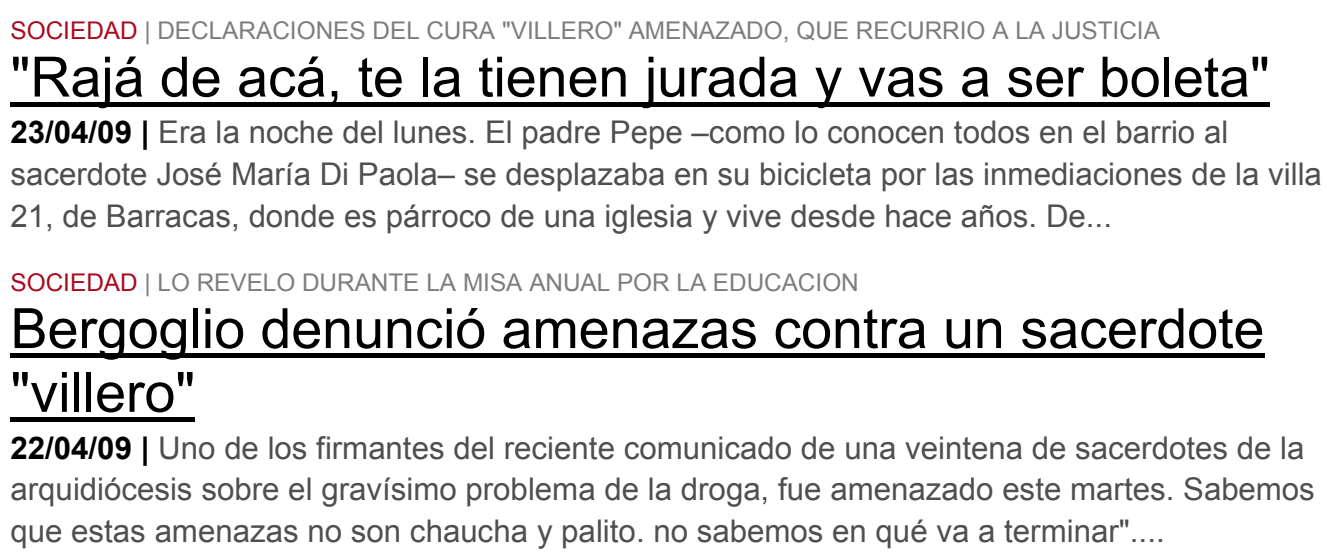

De este modo se construyó una figura de Bergoglio cercano a las villas de emergencia, figuración que resaltaron los medios cuando fue elegido sumo pontífice. También en 2009 hubo noticias sobre los sectores en conflicto del Vaticano: 


\title{
Benedicto XVI: aniversario papal en medio de una crisis sin precedentes
}

\author{
17/04/09 | Mañana se cumple el cuarto aniversario de la muy preparada elección del mejor de la \\ Curia Romana, órgano central de gobierno de la Iglesia: el 19 de abril de 2005, Joseph \\ Ratzinger, ministro para la defensa de la sana doctrina del Vaticano y el más... \\ EL MUNDO I LOS "CLANES" SE MUEVEN SEGUN INTERESES PUNTUALES

\section{La interna del Vaticano, al rojo vivo por el perdón a los lefebvristas} \\ 07/02/09 | Se oyó la voz fuerte, destemplada (está un poco sordo) del cardenal Giovann Battista \\ Re, que no ocultaba su bronca: "Castrillón, Pastichón". Acomodado en uno de los primeros \\ asientos del pullman que el 25 de enero llevaba a cardenales, obispos y...
}

En 2008, otras noticias trataron sobre la relación "tensa" entre el gobierno y la Iglesia Católica argentina: la calificación recurrente que veíamos con la palabra "escándalo" se repite aquí con la adjetivación acerca de las tensiones. En otras oportunidades CL y CL.COM titulaban acerca de los gestos de acercamiento o distanciamiento relacionados con las supuestas situaciones de tensión.

Otras noticias sobre religión en este medio, señalan que Benedicto XVI quería volver a instaurar la misa del Concilio de Trento, en latín y de espaldas a los fieles, anterior a las reformas del Concilio Vaticano II:

\section{EL MUNDO | MODIFICACIONES EN LA IGLESIA CATOLICA \\ La reforma de la misa, a cargo de un cardenal ultraconservador \\ 25/11/08 | Los enconos están al rojo vivo entre la España laica y la Iglesia ibérica, agravados por el caso del crucifijo y los símbolos religiosos en una escuela pública de Valladolid, que ordenó retirar un juez en nombre del Estado no confesional. Uno de los...}

A mediados de 2008, el conflicto entre el gobierno y el campo ocupó varios titulares:

\section{POLITICA | BERGOGLIO DESCARTO UNA MEDIACION ECLESIASTICA \\ La Iglesia pide que Cristina llame al diálogo y el campo levante el paro \\ 05/06/08 | En medio de un agravamiento del conflicto entre el Gobierno y el campo, la Iglesia le pidió ayer "encarecidamente" a la presidenta Cristina Kirchner que "convoque con urgencia a un diálogo transparente y constructivo con los dirigentes rurales".... intención de mediar}


03/06/08 | La Iglesia no se ofrecerá como mediadora en el interminable conflicto del Gobierno de Cristina Fernández y Néstor Kirchner con el campo. Pero la Conferencia Episcopal renovará el llamado a un diálogo urgente entre las partes y formulará...

POLITICA | PARTE HOY PARA PARTICIPAR DE UNA CONFERENCIA SOBRE LA CRISIS MUNDIAL DE ALIMENTOS

\section{Cristina viaja a Roma con la pelea del campo como}

\section{telón de fondo}

31/05/08 | El viaje que emprenderá hoy Cristina Kirchner a Roma podría venirle bien para tomar distancia del infierno en que se ha convertido el conflicto entre el Gobierno y el campo.Eso no quiere decir, aunque tiene previsto alojarse en el Hotel Eden, que en...

POLITICA | PIDEN EL APOYO DE LA IGLESIA, LA CORTE SUPREMA, EL CONGRESO Y EL DEFENSOR DEL PUEBLO

\section{El campo volvió al paro y no se venderán granos ni}

\section{hacienda}

28/05/08 | El campo anunció ayer su tercer paro en menos de tres meses. Será de seis días: comenzó anoche y durará hasta el lunes; los productores no venderán ni granos ni carne. Según los dirigentes del sector, esta protesta fue empujada por las...

POLÍTICA | LA CUPULA DEL EPISCOPADO, CON EL CARDENAL BERTONE

\section{Bergoglio analizó en el Vaticano los roces de la Iglesia y el Gobierno}

27/05/08 | El "primer ministro" del Papa, cardenal Tarcisio Bertone, recibió ayer a la mañana en su despacho en el Palacio Apostólico a la mesa ejecutiva de la Conferencia Episcopal argentina, encabezada por el arzobispo de Buenos Aires, cardenal Jorge...

POLITICA | CELEBRACION DE CORPUS CHRISTI

\section{Bergoglio: "El desafío de la hora es permanecer unidos como pueblo"}

24/05/08 | En medio de la fuerte pulseada entre el Gobierno y el campo -que derivó en que la celebración del 25 de Mayo estuviera signada por actos contrapuestos-, la Iglesia convirtió ayer la tradicional celebración del Corpus Christi en un enfático llamado a...

En retrospectiva, se entiende que la discusión de 2009 en torno a la pobreza también involucraba los conflictos que el gobierno había tenido con el campo en 2008 y con la Iglesia Católica argentina, conflictos que ya venían de larga data por ejemplo con las celebraciones del Te Deum.

CL y CL.COM editaban la información con componentes críticos hacia el gobierno respecto a esta situación, cuando es potestad del presidente de la República elegir el lugar donde se celebra el Te Deum:

\section{Cristina rompe una tradición de 198 años: no habrá}

\section{Tedéum el 25 de Mayo}

13/05/08 | Cristina Fernández de Kirchner no sólo continuará el camino iniciado por su marido de trasladar a una ciudad del interior el Tedéum del 25 de Mayo que tradicionalmente se celebró en la Catedral de Buenos Aires para esquivar una homilía que presume... 
Las noticias que referían a la palabra clave Cardenales tuvieron en 2007 informaciones relacionadas a la elección de dos nuevos cardenales argentinos y a la beatificación de Ceferino Namuncurá, el año en que Cristina Fernández de Kirchner fue electa presidente de la nación:

EL MUNDO | CONSISTORIO EN EL VATICANO CON FUERTE TENDENCIA EUROCENTRISTA

\section{Dos cardenales argentinos, entre los nuevos 23 nombrados por el Papa}

24/11/07 | El Papa nombró ayer en una solemne ceremonia celebrada en la basílica de San Pedro y no en la plaza por temor a la lluvia, a 23 nuevos cardenales, entre ellos los argentinos Leonardo Sandri, 64, y Estanislao Karlic, 81. Benedicto XVI acentuó los...

EL MUNDO | AMERICA LATINA AUN NO TIENE LA REPRESENTATIVIDAD QUE LE DA SU NUMERO DE FIELES

\section{El Papa nombra hoy a 23 nuevos cardenales y dos son argentinos}

23/11/07 | El Papa nombrará esta mañana a 23 nuevos cardenales, entre ellos los argentinos Leonardo Sandri (63) y Estanislao Karlic, (81), en una ceremonia en la plaza de San Pedro. Los nuevos príncipes de la Iglesia recibirán de manos del Papa cada uno el...

\section{Con una ceremonia mapuche, consagraron beato a}

\section{Ceferino}

11/11/07 | En una multitudinaria, colorida y emotiva ceremonia, que combinó los rituales mapuches con la liturgia católica, el indiecito Ceferino Namuncurá -el católico más popular de la Argentina- fue declarado ayer aquí beato poco más de un siglo después de...

POLÍTICA | GESTO DE ACERCAMIENTO DE LA IGLESIA A LA PRESIDENTA ELECTA

\section{Bergoglio felicitó a Cristina por carta y se comprometió a rezar por su gestión}

01/11/07 | Después de más de tres años de haber estado en un potente freezer, las relaciones entre el matrimonio presidencial y el Episcopado comienzan a mostrar tenues señales de descongelamiento. Pruebas al canto: la cúpula del Episcopado -encabezada por el...

POLITICA | LA RELACION DEL NUEVO GOBIERNO CON LA CUPULA ECLESIASTICA

\section{Reacción positiva de la Iglesia ante los primeros gestos de Cristina}

30/10/07 | Las últimas señales como candidata y las primera como presidente electa de Cristina Fernández de Kirchner cayeron bien en la Iglesia. Tanto "su actitud conciliadora" que pronunció la noche del domingo, cuando despuntaba su triunfo, como la...

Otras noticias que mencionaban a Bergoglio estaban relacionadas con incipientes críticas del Episcopado católico argentino al gobierno de Néstor Kirchner, o por el juicio a Von Wernich:

\section{Bergoglio criticó la falta de diálogo}


15/09/07 | El arzobispo de Buenos Aires, cardenal Jorge Bergoglio, volvió a criticar elípticamente ayer el estilo de diálogo institucional del presidente Néstor Kirchner, al asegurar que "la crispación no contribuye a la cultura del encuentro"."Es necesario...

\section{Juicio contra Von Wernich: una testigo cuestionó a}

\section{Bergoglio}

03/09/07 | La hermana de Elena de la Cuadra, quien tuvo una hija en cautiverio, cuestionó ayer al cardenal Jorge Bergoglio por su "silencio" en torno a la causa que se lleva adelante contra el cura Christian Von Wernich. Y declaró haber escuchado Von Wernich...

POLITICA | OTRO CRITICO DOCUMENTO DEL EPISCOPADO

\section{La Iglesia reclama diálogo y dice que no basta con que crezca la economía}

23/08/07 | En una semana signada por el conflicto en Santa Cruz y el insistente reclamo de los manifestantes para que la provincia del presidente Kirchner deje de ser manejada por el primer mandatario, la Iglesia volvió a reclamar "la promoción de un verdadero...

A diferencia de las declaraciones sobre la pobreza en 2008 y 2009, el Episcopado católico argentino reconocía en 2007 el crecimiento económico local, según este titular, aunque un término que luego fue resonante -el de "escándalo"- ya se había utilizado:

\section{POLITICA | DEFINICIONES DE MONSEÑOR FERNANDO BARGALLO \\ La Iglesia insiste en denunciar la "escandalosa" desigualdad social}

07/06/07 | Debemos celebrar la recuperación de la economía argentina y la mejora en los índices macroeconómicos. Pero también debemos preguntarnos, sin ánimo de criticar a nadie en particular, si este crecimiento económico es un crecimiento de todos y para...

El subtítulo de la nota firmada por el periodista especializado en religión de CL y CL.COM, Sergio Rubín, era parte de un entrecomillado y pertenecía a las declaraciones del obispo de Merlo-Moreno:

\footnotetext{
"Debemos celebrar la recuperación de la economía argentina y la mejora en los índices macroeconómicos. Pero también debemos preguntarnos, sin ánimo de criticar a nadie en particular, si este crecimiento económico es un crecimiento de todos y para todos, si no sigue habiendo un sector enorme de la población que continúa luchando por su supervivencia".

La reflexión pertenece al presidente de Cáritas, la institución oficial de la Iglesia para la ayuda a los más necesitados, Fernando Bargalló, obispo de Merlo-Moreno y se conoce en medio de la campaña electoral porteña por la segunda vuelta entre el candidato oficialista Daniel Filmus y el titular de PRO, Mauricio Macri, el domingo 24 de junio.
}

Ese año hubo varias noticias sobre la reunión de los obispos católicos en la cumbre de la CELAM en Aparecida, Brasil:

\section{"La Iglesia no adoptará una actitud proselitista por la pérdida de fieles"}


03/09/07 | La Iglesia católica negó que vaya a adoptar "una actitud proselitista" por la pérdida de fieles que sufre en América Latina, ni librará una "guerra" contra los nuevos movimientos religiosos, sino que impulsará una revitalización espiritual de sus...

EL MUNDO | QUEJAS DE LOS PURPURADOS POR EL DOCUMENTO DE LA ULTIMA CUMBRE DEL CELAM EN BRASIL

\section{El Vaticano modificó un texto clave de los obispos}

\section{latinoamericanos}

22/08/07 | El documento final que aprobaron los 266 obispos de las conferencias episcopales latinoamericanas en la asamblea del CELAM fue alterado con más de 200 enmiendas en el documento "oficial" que aprobó el papa Benedicto XVI en el Vaticano. Las...

Las reuniones del cardenal Bergoglio con políticos opositores al gobierno kirchnerista fueron frecuentes pese a que era un año electoral:

\section{POLITICA | ENCUENTRO CRISTIANO}

\section{Carrió, en un acto de Bergoglio}

20/08/07 | La precandidata presidencial Elisa Carrió participó ayer de un acto interreligioso en el Luna Park en el que habló el arzobispo de Buenos Aires, cardenal Jorge Bergoglio."No privaticemos el Evangelio, no privaticemos el nombre de Jesús", dijo...

\section{Bergoglio recibió a Michetti y a Castells y reiteró sus críticas \\ 08/08/07 | El arzobispo de Buenos Aires, cardenal Jorge Bergoglio, pareció ayer responderle a quienes, desde el Gobierno, lo critican por considerar que tiene una actitud opositora y sólo recibe a dirigentes que están en la vereda de enfrente del oficialismo...}

POLITICA | FRENTE A UNA MULTITUD REUNIDA EN SAN CAYETANO

\section{Bergoglio cuestionó el clientelismo político, la "dádiva $\mathrm{y}$ los privilegios" \\ 07/08/07 | En pleno año electoral y en el emblemático marco de la festividad de San Cayetano Patrono del pan y del trabajo-, el presidente del Episcopado, cardenal Jorge Bergoglio, criticó ayer el clientelismo político y la dádiva. A la vez que advirtió sobre...}

POLÍTICA | EN MEDIO DE LA TENSION ENTRE LA CASA ROSADA Y LA IGLESIA

\section{Macri se reunió con Bergoglio y generó suspicacias en el Gobierno}

02/08/07 | No hubo gestos ampulosos ni definiciones de peso. Ni siquiera circuló una fotografía como prueba del encuentro. Para los voceros del cónclave sólo se trató de un diálogo institucional, protocolar. Pero, aun así, la cita no dejó de convertirse en una...

\section{Bergoglio ante Moyano: "No se construye desde la queja, sino desde la lucha"}

30/06/07 | En el marco de la prédica que viene desarrollando la Iglesia en favor de un mayor compromiso cívico, dejando de ser meros habitantes para pasar a ser auténticos ciudadanos, el presidente del Episcopado, cardenal Jorge Bergoglio, advirtió ayer aquí...

\section{López Murphy, a solas con Bergoglio}


27/06/07 | Cuarenta y ocho horas después de la doble derrota del Gobierno que renovó las expectativas de la oposición para las elecciones presidenciales, Ricardo López Murphy se reunió el martes en el arzobispado con el cardenal Jorge Bergoglio, considerado...

Ya en la cumbre de la CELAM el tema de la pobreza había sido un tópico entre los obispos de América Latina y, evidentemente, era un punto de encuentro entre las preocupaciones de Ratzinger y Bergoglio:

EL MUNDO | LA CUMBRE DEL CELAM EN APARECIDA, BRASIL, EL 13 DE MAYO

\section{La pobreza, en el centro del debate de los obispos latinoamericanos}

04/05/07 | Tras obtener el "pleno apoyo" del Papa en una audiencia que les concedió ayer por la mañana, un grupo de altos prelados de los cinco continentes, encabezados por el cardenal hondureño Oscar Rodríguez Maradiaga, reclamó a los países más ricos del...

Las preocupaciones del Vaticano respecto a religiosos católicos latinoamericanos con candidaturas políticas fueron noticia a comienzos de 2007:

POLÍTICA | MONSEÑOR BERGOGLIO QUIERE EVITAR ROCES CON EL VATICANO, QUE SE OPONE A ESTAS INCURSIONES

Curas candidatos: una moda que se extiende y preocupa a la Iglesia

20/02/07 | La incursión de clérigos en el campo político comienza a ser un dolor de cabeza para la Iglesia argentina. La exitosa candidatura a convencional constituyente del obispo Joaquín Piña en Misiones para oponerse a la reelección indefinida que buscaba..

EL MUNDO | LA HEGEMONIA DEL PARTIDO COLORADO

\section{Paraguay: el Vaticano suspendió al obispo que busca ser presidente \\ 01/02/07 | El obispo paraguayo Fernando Lugo, de 55 años, fue suspendido "a divinis" de su cargo por la Santa Sede, negándole el pedido de ser reducido al estado laical para participar como candidato presidencial en las elecciones presidenciales de $2008, \ldots$}

La relación entre el Episcopado católico argentino y el gobierno kirchnerista fue tratada en muchas oportunidades por CL y CL.COM aunque en este caso consideraron la disputa en 2005 y 2006 con el obispo castrense Antonio Baseotto como el comienzo del conflicto:

\section{POLITICA | EL CONFLICTO POR EL OBISPO CASTRENSE ANTONIO BASEOTTO, COMO TRASFONDO \\ El Papa recibió a Bergoglio: hablaron de la tensa relación con Kirchner}

14/01/07 | El Papa recibió ayer en el Palacio Apostólico vaticano al cardenal Jorge Bergoglio y a los otros tres obispos miembros de la Comisión Ejecutiva de la Conferencia Episcopal de nuestro país. Fue un encuentro cordial, en el que Benedicto XVI hizo... 
POLITICA | PULSEADA POR EL OBISPO QUE PIDIO TIRAR AL MINISTRO DE SALUD AL MAR

\title{
Bergoglio analizó el caso Baseotto con altas autoridades del Vaticano
}

\author{
13/01/07 | El delicado caso del obispo castrense, monseñor Antonio Baseotto, fue evocado ayer \\ por el cardenal Jorge Bergoglio y los tres obispos que con él integran la Comisión Ejecutiva de la \\ Conferencia Episcopal argentina, durante el encuentro con el...
}

POLÍTICA | LA VISITA DEL CARDENAL ARGENTINO A ROMA

\section{Bergoglio habló en el Vaticano de su tensa relación con Kirchner}

11/01/07 | En el encuentro de trabajo más importante de su visita, el cardenal Bergoglio y los otros tres obispos de la Comisión Ejecutiva de la Conferencia Episcopal argentina se reunieron ayer con el nuevo "primer ministro" de la Curia Romana, el gobierno...

Pese a que en otra noticia se señalaba la renuncia de Guillermo Marcó como vocero de Bergoglio, por una crítica que le había hecho a Kirchner:

\section{POLITICA | HABIA CRITICADO RECIENTEMENTE A KIRCHNER \\ Marcó deja de ser el vocero de Bergoglio}

13/12/06 | El presbítero Guillermo Marcó - quien en octubre cobró notoriedad por un duro cruce con el presidente Néstor Kirchner- dejará de ser el vocero del arzobispo de Buenos Aires,

cardenal Jorge Bergoglio. La salida de Marcó fue enmarcada dentro de una...

Antes, el mismo medio había publicado:

\section{ZONA | EL PRESBITERO GUILLERMO MARCO CRITICO AL PAPA}

\section{El Vaticano está furioso con el vocero de Bergoglio}

07/10/06 | El caso argentino volvió a instalarse inesperadamente en estos días en el Vaticano y por momentos "no se habló de otra cosa", dijo una fuente interna a Clarín. Pero el tema que agitó al Palacio Apostólico tuvo muy poco que ver con el conflicto...

En 2006 también hubieron varias noticias sobre las relaciones entre el gobierno de Kirchner y el Episcopado católico argentino, aunque fue notoria la insistencia de CL y CL.COM en promover e insistir en el tópico de las reuniones o la falta de encuentros entre ambos como motivos de conflictos, oposiciones, distensiones, acercamientos, "gestos":

\footnotetext{
OPINIÓN | PANORAMA POLITICO ¿La Iglesia, al frente de la oposición?

07/10/06 | La tensión actual entre Néstor Kirchner y la Iglesia no puede representar ninguna sorpresa. Ha sucedido solamente otra ráfaga de palabras y de actos hostiles. La novedad, en todo caso, sería la nueva percepción presidencial sobre las razones ocultas...

ZONA

Para Kirchner, es un problema político y también personal
} 
07/10/06 | El problema, dicen en el Gobierno, no es con la Iglesia sino con el cardenal Jorge Bergoglio. La explicación, sencilla apenas en las formas, da en realidad una idea de la dimensión del conflicto: Bergoglio es el presidente del Episcopado y, al menos...

ZONA | QUE HAY DETRAS DE LA PELEA: UN CONFLICTO POLITICO QUE LLEGO A SU MAXIMA TENSION

\section{La Iglesia insistirá en un rol crítico hacia Kirchner}

07/10/06 | La Iglesia decidió presentarle batalla a Néstor Kirchner. La estrategia combativa está en marcha y Kirchner lo sabe. Ya no serán sólo declaraciones críticas, sino también gestos que evidencien el cuestionamiento al estilo presidencial confrontativo,...

\section{Bergoglio, verdadero destinatario de la carga del Presidente}

05/10/06 | Nadie cree en la Iglesia que la bronca que el presidente Kirchner descargó ayer desde una tribuna haya sido para el vocero del cardenal Jorge Bergoglio, el presbítero Guillermo Marcó, por haberlo acusado de sembrar divisiones. La impresión extendida...

POLÍTICA | DESPUES DE LOS CRUCES TRAS LA SALIDA DEL OBISPO JOAQUIN PIÑA

\section{La Iglesia le baja el volumen a la confrontación con el Gobierno \\ 04/10/06 | En medio de la fuerte tensión entre el Gobierno y la Iglesia, el arzobispado de Buenos Aires emitió ayer una señal de distensión. La curia metropolitana salió a decir que las duras críticas al presidente Néstor Kirchner que el vocero del cardenal...}

POLITICA | HOMILIA DEL PRESIDENTE DEL EPISCOPADO TRAS LA MASIVA MARCHA DE JOVENES A LA BASILICA DE LUJAN

\section{Tensión entre Gobierno e Iglesia: Bergoglio alertó por la "discordia" \\ 01/10/06 | Después de una semana signada por recriminaciones cruzadas por la actuación de instituciones y personas durante la última dictadura — que incluyeron una crítica del presidente Néstor Kirchner a la Iglesia y una durísima réplica de un obispo-, el...}

La asunción de Joseph Ratzinger como sumo pontífice y la prevalencia de los sectores conservadores de la Iglesia Católica percibían a Bergoglio como un competidor en las relaciones de poder, tanto en el Vaticano como en la Argentina.

El momento de mayor tensión que tuvo Bergoglio en sus relaciones con el Vaticano y en la disputa local con Aguer -discípulo de Sandri, como lo indicamos más arriba, que se sentía "respaldado" con la conducción de Ratzinger-, fueron resueltos por estas fechas:

\section{Un arzobispo argentino dejará un cargo estratégico en el Vaticano \\ 08/09/06 | El arzobispo argentino Leonardo Sandri pasará a otro cargo. Tras años de ser íntimo colaborador de los papas Juan Pablo II y Benedicto XVI, nuestro compatriota abandonará las funciones sustituto de la Secretaría de Estado, un cargo estratégico....}


El homenaje por los 30 años de la muerte del obispo Enrique Angelelli buscaba de alguna manera generar un acercamiento hacia la política de derechos humanos que llevaba adelante el gobierno:

POLÍTICA | LOS VINCULOS DEL GOBIERNO CON LA IGLESIA, ENTRE MINISTROS Y OBISPOS

\section{Kirchner y Bergoglio, sin relación: hace dos años que no hay diálogo}

14/08/06 | Néstor Kirchner y Jorge Bergoglio están cumpliendo este mes dos años sin dialogar. Suena a demasiado tiempo en un país donde seis meses parecen una eternidad. Y, sobre todo, dibuja sombras sobre las repetidas afirmaciones en el sentido de que la...

POLITICA | 30Ø ANIVERSARIO DE LA MUERTE VIOLENTA DEL OBISPO DE LA RIOJA

\section{Bergoglio: "Angelelli fue perseguido durante la dictadura"}

05/08/06 | Al cumplirse 30 años de la muerte violenta del obispo Enrique Angelelli, el cardenal primado, Jorge Bergoglio exaltó ayer su tarea pastoral al frente de la diócesis de La Rioja, en la dura década del 70 . En la homilía de la misa oficiada anoche en...

POLÍTICA | MONSEÑOR BERGOGLIO, EN LA RIOJA

\section{Homenaje de la Iglesia a Angelelli}

03/08/06 | Por primera vez, al cumplirse 30 años de su muerte, las máximas autoridades de la Iglesia Católica argentina realizarán hoy una celebración oficial en memoria del ex obispo Enrique Angelelli. El cardenal primado Jorge Bergoglio; el obispo de La...

Otras noticias sobre los líderes católicos argentinos y el Vaticano también fueron publicadas en 2006:

\section{EL MUNDO | EL PRIMER DIGNATARIO DE LA IGLESIA ARGENTINA QUE SERA SANTO \\ El Vaticano inició el proceso de beatificación del cardenal Pironio}
23/06/06 | Será santo algún día el cardenal argentino Eduardo Pironio. Ayer, en el majestuoso escenario de la Sala de la Conciliación del Palacio de San Juan en Letrán, junto a la histórica Basílica del Papa, se inició el proceso de beatificación 8 años...

\section{EL MUNDO I CAMBIOS EN LA CUPULA DE LA IGLESIA}

\section{El Vaticano cierra una etapa: se retira el cardenal Sodano}

22/06/06 | En una sofocante jornada de calor en Italia, el Papa inauguró ayer un nuevo escenario en la vida de la Iglesia Católica. Nombró Secretario de Estado vaticano, o sea el "primer ministro" de la Curia Romana, el gobierno central de la Santa Sede, a un...

\section{Una salida ansiada en Argentina por los obispos y el Gobierno}

22/06/06 | "Parece que falta poco para la salida de Sodano", decía por lo bajo hace pocos días un conspicuo obispo argentino, cuando arreciaban las versiones de un recambio en la poderosa Secretaría de Estado del Vaticano. "Solo hace falta que soplemos un... 


\section{Cardenal Sodano: me iré "cuando el Papa lo quiera"}

18/06/06 | El Secretario de Estado vaticano, cardenal Angelo Sodano, dijo ayer que "los años pasan para todos y espero poder transmitir a otros mi dicasterio, cuando el Papa lo quiera".El purpurado comentó así las versiones de su inminente sustitución en la...

La muerte del cardenal Primatesta tuvo espacio en Clarín y CL.COM como también el encuentro entre Kirchner y Bergoglio en un homenaje a los curas Palotinos en 2006, que reunía derechos humanos e Iglesia Católica:

\section{POLITICA | CUATRO VECES PRESIDENTE DEL EPISCOPADO}

\section{Murió el cardenal Primatesta, una de las figuras más influyentes de la Iglesia}

01/05/06 | No quiso ir a una clínica. Prefirió pasar sus últimos días en un modesto departamento de Córdoba. La calma con que esperó la muerte contrastó con una trayectoria agitada en tiempos álgidos para el país, producto de haber sido durante un cuarto de...

POLITICA | ORACION INTERRELIGIOSA POR LOS CURAS PALOTINOS ASESINADOS EN LA DICTADURA

\section{Señal del Gobierno: Kirchner se vio con Bergoglio en un oficio religioso}

12/04/06 | Aunque ambos protagonistas se negaron una y otra vez a confirmar la existencia de un clima de acercamiento tras la fría relación del último año, tanto Néstor Kirchner como el cardenal Jorge Bergoglio intercambiaron ayer gestos de mutua cordialidad...

Clarín y CL.COM se ocupaban en especial de las relaciones tensas entre gobierno y Episcopado católico argentino, y de éste con el Vaticano:

ZONA

\section{Los principales sectores en la cúpula episcopal}

04/03/06 | Dialoguistas El principal referente es monseñor Jorge Casaretto, obispo de San Isidro y presidente de la Comisión de Pastoral Social. Considera que debe hacerse un marcado esfuerzo por construir un puente de diálogo con el Gobierno. Tiene llegada...

EL MUNDO | LOS CAMBIOS EN LA IGLESIA CATOLICA

\section{Benedicto XVI nombró a 15 nuevos cardenales}

22/02/06 | Como adelantó Clarín en su edición de ayer, Benedicto XVI anunció que ha decidido "crear" una docena de nuevos cardenales electores menores de 80 años (en condiciones de elegir a un nuevo Papa en el Cónclave) y tres mayores de esa edad, que están...

\section{Una señal del Vaticano hacia el Episcopado}

22/02/06 | Luego de la tensión que se generó entre el Vaticano y la conducción de la Iglesia argentina por las últimas designaciones de obispos, la Santa Sede emitió ayer una señal conciliadora: el papa Benedicto XVI nombró al frente de la diócesis cordobesa... 
Bergoglio y Ratzinger habían estado en una relación conflictiva por la competencia en los votos del concilio que sucediera a la muerte de Juan Pablo II y que eligiera a Ratzinger como sumo pontífice, en el cual el jesuita argentino había tenido chances de disputarle ese puesto:

\section{OPINIÓN | KIRSCHBAUM \\ Una atención inusitada}

04/02/06 | Un influyente diario italiano publicó ayer una crónica sobre la poca sintonía que parece existir entre la Secretaría de Estado de la Santa Sede y el cardenal primado de la Argentina, Jorge Bergoglio. El motivo: las designaciones de obispos que no...

POLÍTICA | LA RELACION CON ROMA

\section{Bergoglio pega la vuelta, después de una difícil visita al Vaticano}

04/02/06 | Para el cardenal Jorge Bergoglio llegó el tiempo de las valijas y de la partida. Pero también de las evaluaciones. Esta noche emprenderá el regreso hacia Buenos Aires después de su paso más comentado por El Vaticano, su presencia en abril, cuando..

POLITICA | RECAMBIO DE OBISPOS

\section{Siguen las dudas, cuando faltan siete nombramientos}

04/02/06 | Es el secretario de Estado, cardenal Angelo Sodano? ¿Es su principal colaborador, el arzobispo argentino Leonardo Sandri? ¿Es el ex embajador del menemismo ante El Vaticano Esteban "Cacho" Caselli?. ¿Quiénes, realmente, están influyendo en las...

POLITICA | ANTECEDENTES

\section{Los cargos que generan inquietud}

03/02/06 | Las últimas designaciones de obispos en la Iglesia argentina no respondieron a las preferencias mayoritarias del Episcopado argentino. En rigor, el primer antecedente —que se convirtió en un fuerte toque de atención en los medios eclesiásticos..

\section{Con Bergoglio esperando en Roma, el Papa designó a} un nuevo obispo

03/02/06 | En otra señal hostil lanzada al presidente de la Conferencia Episcopal y cardenal primado de la Argentina, Jorge Bergoglio, un nuevo obispo del sector más conservador de la Iglesia fue nombrado ayer por el Papa. Un interlocutor de Clarín admitió que...

\section{La Iglesia busca distender el clima creado por los} últimos nombramientos

03/02/06 | La Iglesia argentina emitió ayer señales tendientes a desinflar la tensión que se creó entre ésta y el Vaticano luego de que la Santa Sede no optó en sus últimas designaciones de obispos por los principales candidatos sugeridos por el Episcopado....

En 2005, Clarín y CL.COM destacaban las noticias sobre las relaciones entre el gobierno y la Iglesia Católica, la elección de Bergoglio como presidente de la Conferencia Episcopal Argentina: 


\section{La Iglesia y el Gobierno, en una relación en punto muerto}

30/12/05 | Si el espíritu navideño —al que se abrazaron con singular fervor los obispos en su última reunión del año- alcanzó para conmover al presidente de la Nación. Apenas un puñado de días después de que el Episcopado —en su mensaje con motivo de la...

POLÍTICA | DURO DOCUMENTO SOBRE LA REALIDAD NACIONAL

\section{Para la Iglesia, hay "crecimiento escandaloso de la desigualdad" \\ 13/11/05 | En el primer pronunciamiento sobre la realidad nacional desde que asumió la Presidencia Néstor Kirchner, la Iglesia pareció no guardarse nada. Los obispos —ante todo- denunciaron "el crecimiento escandaloso de la desigualdad en la distribución de...}

\section{Recambio en la Iglesia: Bergoglio podría quedar al frente del Episcopado}

06/11/05 | El centenar de obispos del país iniciarán este lunes su segundo y último plenario del año durante el que elegirán a sus nuevas autoridades. Todo indica que el arzobispo de Buenos Aires, cardenal Jorge Bergoglio —actual vicepresidente primero—, sería...

\section{POLÍTICA | LUEGO DE LA ELECCION}

\section{La Iglesia espera cambios en la relación con Kirchner}

01/11/05 | Para mejor o para peor, hacia fin de año otro será el marco de la relación entre el Gobierno y la Iglesia. Los recientes comicios legislativos — de las que el presidente Néstor Kirchner salió fortalecido-, las inminentes elecciones en el Episcopado...

Podemos observar que en 2005 el Episcopado católico argentino hablaba de "crecimiento escandaloso de la desigualdad" y no del "escándalo de la pobreza". Si bien se mantenía el adjetivo escandaloso, el sustantivo desigualdad no tuvo la fuerza que tenía en 2009 para hablar de pobreza. Estos llamados "sustantivos abstractos" de todos modos son fuertemente calificativos, ya que derivan de adjetivos (por ejemplo, pobreza) ${ }^{123}$.

En ese año, también hubo noticias sobre cómo fue la elección en el cónclave papal:

\footnotetext{
123 "Un Sustantivo abstracto es aquel sustantivo que designa un objeto sólo percibido o creado por el pensamiento, en oposición a los sustantivos concretos, que designan objetos perceptibles por los sentidos. "Como los distintos grados de concreción y de abstracción corren sin interrupción de un extremo al otro, resulta que, por la misma naturaleza del asunto, es imposible trazar la división exacta entre los nombres concretos y los abstractos.", (Sahil Ureña y Amado Alonso)", disponible en https://es.wikipedia.org/wiki/Sustantivo_abstracto [Consultado: 3/11/2016].
} 
EL MUNDO | FRAGMENTOS DEL DIARIO PERSONAL DE UN PURPURADO DURANTE EL CONCLAVE

\section{Intimidades de una votación: cómo fue la carrera entre Bergoglio y Ratzinger}

22/09/05 | Domingo 17 de abril. "Esta tarde tomé posesión de la habitación en la Casa Santa Marta. Apenas dejé las valijas traté de abrir las persianas porque la habitación estaba a oscuras. No pude. La explicación fue que las persianas habían sido selladas....

\section{EL MUNDO | DETALLES DE UNA COMPLEJA INTERNA EN LA CUPULA DE LA IGLESIA}

\section{Revelan que hubo un acuerdo secreto para elegir al actual Papa}

17/09/05 | El del 18-19 de abril más que un Cónclave hubo un plebiscito que confirmó el poder de coalición de la Curia Romana, que había elegido bastante tiempo antes al cardenal Joseph Ratzinger como sucesor de Juan Pablo II, con el tácito consentimiento del...

\section{Mencionan al cardenal Bergoglio para un alto cargo en}

\section{El Vaticano}

16/09/05 | El Papa está preparando el equipo que lo acompañará en el ejercicio de su pontificado, que el lunes cumplirá cinco meses. Haría el anuncio en noviembre o diciembre, después del Sínodo de la Eucarístía que tendrá lugar durante octubre. En las..

\section{Bergoglio, en el medio de una movida que preocupa al} Gobierno

16/09/05 | El Gobierno conocía desde hacía semanas la versión sobre una inminente reorganización del equipo del papa Benedicto XVI, que incluiría la designación del cardenal Jorge Bergoglio en lugar del influyente secretario de Estado, Angelo Sodano. Tanto,...

POLITIICA | LOS OBISPOS ARGENTINOS, ATENTOS AL FUTURO DE MONSEÑOR BERGOGLIO

\section{Cautela en la Iglesia por una movida que podría repercutir en su interna}

15/09/05 | Suma cautela. Esa fue la actitud que se percibió ayer en los medios eclesiásticos vernáculos ante las versiones de que el arzobispo de Buenos Aires, cardenal Jorge Bergoglio, reemplazaría al cardenal Angelo Sodano al frente de la poderosa secretaría...

Entre las noticias sobre religión acerca de nuestro país reaparece el tópico del Te Deum, entre otras informaciones que se relacionaban con el cardenal Bergoglio, además de la continuidad informativa sobre el Papa electo, Benedicto XVI:

\section{POLITICA | POR PRIMERA VEZ LA MISA POR EL 25 DE MAYO NO SE HARA EN BUENOS AIRES \\ El Tedéum en Santiago suma otro roce entre el Presidente y Bergoglio}

22/05/05 | Las relaciones entre el presidente Néstor Kirchner y el arzobispo de Buenos Aires y cardenal primado, Jorge Bergoglio, no atraviesan un buen momento. Kirchner le acaba de infligir un severo desaire, al decidir trasladar el Tedéum del 25 de Mayo a...

\section{El Tedéum, otro problema con la Iglesia}

14/05/05 | La casi segura decisión de Néstor Kirchner de no encabezar el Tedéum del 25 de Mayo en la catedral metropolitana, sino en otro templo de una capital de provincia, suscita interrogantes en los medios católicos sobre los verdaderos motivos del.. 
POLITICA | SOSPECHAN QUE ALGUNOS SECTORES ACTUAN EN CONTRA DEL CARDENAL

\section{En la Iglesia ven maniobras para perjudicar a Bergoglio}

09/05/05 | El camino ascendente del cardenal Jorge Bergoglio en la consideración de la Iglesia - que se tradujo en el hecho de haber sido el latinoamericano que más votos obtuvo en una elección papal— no estuvo exento de piedras. En los medios eclesiásticos se...

OPINIÓN | EDITORIAL

\section{La llegada del nuevo Papa}

21/04/05 | La elección del cardenal alemán Joseph Ratzinger como nuevo Papa ha disipado rápidamente la incertidumbre sobre el futuro despertada durante la agonía y muerte de Juan Pablo II. Una larga etapa signada por profundos cambios en el mundo, la que...

EL MUNDO | EL CARDENAL ARGENTINO JORGE MEJIA

\section{"Ratzinger es un verdadero líder, discreto, respetuoso de las opiniones de todos"}

21/04/05 | El cardenal argentino Jorge Mejía - un hombre enrolado en un progresismo moderado - se muestra feliz por la elección de Joseph Ratzinger como Papa. Radicado desde hace un cuarto de siglo en la Santa Sede, donde fue director de la Biblioteca y el...

EL MUNDO | EL ARGENTINO SUPERO AL CARDENAL TETTAMANZI, EL OTRO FAVORITO JUNTO CON EL FLAMANTE PAPA

\section{En Italia dicen que Bergoglio llegó a estar segundo en el Cónclave}

21/04/05 | El cardenal Jorge Bergoglio dio el batacazo en el Cónclave que acaba de elegir Papa. Su nombre no sólo apareció en los escrutinios —como muchos vaticinaban desde hacía tiempo-, sino que su candidatura fue creciendo con las sucesivas votaciones hasta..

\section{EL MUNDO | PERFILES}

\section{Argentinos con llegada al Pontífice}

21/04/05 | Jorge Bergoglio ARZOBISPO DE BUENOS AIRES Siempre tuvo diálogo fluido y respetuoso con Ratzinger a partir de sus respectivas funciones eclesiásticas. La destacada participación de ambos en el reciente cónclave intensificó el vínculo. Aseguran en...

INFORMACIÓN GENERAL | EL ESTILO Y ELECCIONES DEL NUEVO PAPA

\section{Llevará a la Iglesia por un camino de ortodoxia}

19/04/05 | El Cónclave de un solo día y cuatro votaciones que eligió Papa al cardenal Joseph Ratzinger, favorito en los pronósticos, líder de los conservadores de la Iglesia y abanderado de la continuidad con el papado tradicionalista de Juan Pablo II, ha...

\section{Un latinoamericano muy bien posicionado}

09/04/05 | Nadie lo vio venir. Ni él mismo se lo imaginaba. El meteórico ascenso de Jorge Mario Bergoglio (68) en la Iglesia sorprendió a propios y extraños. De ser un sacerdote más en un templo jesuita de Córdoba a llegar una década después a obispo auxiliar,...

\section{EL MUNDO | EL CONCLAVE}

\section{El Cónclave: preparativos para una semana decisiva}

07/04/05 | Con la llegada a Roma del arzobispo de Buenos Aires, el jesuita Jorge Bergoglio, anoche se acercaban a 150 los cardenales presentes de los 183 que forman el Sacro Colegio. Ayer se celebró la quinta congregación de la sede vacante mien tras en la...

\section{$\underline{\text { Un apoyo polaco a Bergoglio }}$}


05/04/05 | El arzobispo de Varsovia y primado de Polonia, cardenal Jozef Glemp, aseguró que su par de Buenos Aires, el cardenal Jorge Bergoglio, reúne "todas las condiciones" para ser el sucesor de Juan Pablo II, informó ayer la agencia de noticias DyN. "Mi...

OPINIÓN | ROA

\section{¿Un Papa latinoamericano?}

05/04/05 | América latina es el centro demográfico del catolicismo universal. Se calcula que hay unos 1.100 millones de católicos en el mundo y 450 millones viven aquí. Las tasas de natalidad auguran que en pocas décadas los latinoamericanos serán la mayoría...

EL MUNDO | LA SUCESION DE JUAN PABLO ||

\section{El Primado de la Argentina rechaza ser considerado un "papable"}

04/04/05 | El arzobispo de Buenos Aires y Primado de la Argentina, cardenal Jorge Bergoglio, está disgustado por versiones periodísticas que lo señalan como uno de los candidatos a suceder al Papa Juan Pablo II, expresó su portavoz, sacerdote Guillermo...

EL MUNDO | EL PAPABLE CARDENAL CLAUDIO HUMMES RECLAMA QUE LA IGLESIA SE MODERNICE

\section{Audaz propuesta de la Iglesia brasileña}

03/04/05 | El cardenal brasileño Claudio Hummes, obispo que figura en la lista de los papables, declaró ayer que urge una renovación de la Iglesia Católica. Dijo que ésta precisa "adaptarse al mundo moderno" y advirtió que "la Iglesia no puede dar respuestas...

La muerte de Juan Pablo II en 2005 fue una noticia que desencadenó informaciones sobre el cónclave y los candidatos a ser elegidos como sumo pontífice:

\section{EL MUNDO | EL VIAJERO DE LA FE \\ Murió Juan Pablo II y se cierra un capítulo histórico \\ 03/04/05 | Devastado el organismo por una infección generalizada, tras dos días de agonía, el fuerte corazón de Karol Wojtyla, que el 20 de mayo debía cumplir 85 años, cesó de resistir a las 21.37 hora romana (las 16.37 en Argentina). La muerte del Papa que... \\ EL MUNDO | UNA AMPLIA LISTA DE CANDIDATOS AL TRONO DE PEDRO \\ Bergoglio, posible sucesor \\ 02/04/05 | El diario Le Monde de París, un periódico de extraordinario prestigio internacional, incluye al cardenal argentino Jorge Mario Bergoglio en una exclusiva lista de los cinco candidatos más probables para suceder a Juan Pablo II. "Jorge Mario... \\ EL MUNDO | DE CONFIRMARSE, LA MEDIDA SERIA ADOPTADA DESPUES DE LA PASCUA \\ Podrían retirar a un cardenal clave para la Argentina \\ $\mathbf{2 3 / 0 3 / 0 5}$ | El diario romano II Messaggero dio ayer la versión bomba (sobre todo para la Argentina) del retiro del secretario de Estado, Angelo Sodano, de 77 años, que sería anunciado después de la Pascua. Orazio Petrosillo, el vaticanista del cotidiano más...}

Uno de los principales conflictos entre la Iglesia Católica argentina y el gobierno kirchnerista se remonta hacia 2004 -como ya lo hemos tratado (supra, apartados 5.2, 5.3)-, a partir del debate de la ley de educación sexual y las declaraciones del obispo castrense Baseotto sobre el ministro de salud Ginés Gonzalez García. 
El conflicto giraba en torno de la ley de educación sexual, las políticas de salud sexual y reproductiva y las campañas de anticonceptivos que favoreció el gobierno de entonces.

\section{SOCIEDAD | POLEMICAS DECLARACIONES DE MONSEÑOR BASEOTTO \\ El Gobierno ya pidió al Vaticano que retire al vicario castrense}

24/02/05 | El Gobierno se preocupó ayer por evitar que la relación con el Vaticano se deteriorara luego de que en la víspera el presidente Néstor Kirchner decidió pedirle a la Santa Sede que remueva al obispo castrense, monseñor Antonio Baseotto, por los...

\section{SOCIEDAD | ES MONSEÑOR RENATO MARTINO, TITULAR DE LA PASTORAL SOCIAL DE LA SANTA SEDE \\ Fuerte respaldo de un cardenal del Vaticano al vicario castrense}

22/02/05 | La polémica que suscitaron las duras declaraciones del obispo castrense, monseñor Antonio Baseotto, contra el ministro de Salud, Ginés González García, está lejos de acabar. Ayer, Baseotto recibió un fuerte respaldo de un prominente cardenal del...

\section{Educación sexual: buscan consensuar con la Iglesia}

24/11/04 | Los autores del proyecto de Ley de Educación Sexual porteña que consiguió despacho de mayoría el martes en la comisión de Educación de la Legislatura se reunieron ayer con el arzobispo de Buenos Aires, cardenal Jorge Bergoglio. Ocurrió a pocos días...

\section{Educación sexual: legisladores acuerdan reunirse con Bergoglio \\ 01/11/04 | Las diferencias entre La Legislatura y la Iglesia católica y los demás cultos por el contenido del proyecto de Ley de Educación Sexual en las escuelas porteñas derivaron en los últimos días en un duro choque verbal. El cruce involucró al arzobispo...}

Entre las noticias de 2003 y 2004 se destaca la declaración de Juan Pablo II a favor del acuerdo por la deuda entre el gobierno argentino y el Fondo Monetario Internacional, la oposición a los matrimonios de personas del mismo sexo, el encuentro de Duhalde con Bergoglio a finales del período de la presidencia provisional, luego de la crisis de 2001, la muerte del cardenal Juan Carlos Aramburu:

\section{SOCIEDAD | SUFRIO UN PARO CARDIORRESPIRATORIO \\ Murió el cardenal Aramburu, un protagonista de la historia reciente}

19/11/04 | Uno de los hombres más prominentes de la Iglesia argentina de las últimas décadas, el cardenal Juan Carlos Aramburu, murió ayer en esta capital a los 92 años, a raíz de un paro cardiorrespiratorio. El purpurado fue encontrado sin vida por su...

\section{Mensaje del Papa por la muerte de Aramburu}


19/11/04 | Juan Pablo II expresó ayer su pesar por la muerte del cardenal Juan Carlos Aramburu, arzobispo emérito de Buenos Aires, fallecido el jueves a los 92 años. El Papa destacó la vida "sobria e íntegra" de Aramburu y su "servicio a la Iglesia". También...

POLÍTICA | LA SALUD DEL CARDENAL

\section{Primatesta}

31/10/04 | El cardenal Raúl Primatesta salió ayer de terapia intensiva luego de sortear exitosamente un accidente cerebrovascular. Primatesta — de 85 años— había sido internado de urgencia el jueves último en unag clínica de la ciudad de Córdoba. Su última...

\section{El Papa, "solidario y contento" con el acuerdo por la deuda}

11/03/04 | El Papa dijo que estaba "feliz de que los argentinos vayan arreglando sus problemas económicos" ayer por la mañana, durante los 20 minutos en el diálogo a solas con el canciller Rafael Bielsa. Juan Pablo II habló poco y escuchó mucho. El Pontífice...

EL MUNDO | BREVES

\section{Gente de mundo}

24/11/03 | >JORGE MEJIA Un cardenal dice adiós al Vaticano El cardenal argentino Jorge Mejía se despide del Vaticano. Aunque cumplió 80 años en enero, Juan Pablo II le había ratificado su apoyo como jefe del Archivo Pontificio. Pero, según analistas..

\section{SOCIEDAD | "ALARMA MORAL" EN EL VATICANO CONTRA LAS NUEVAS UNIONES CIVILES}

\section{Juan Pablo II llama a resistir las uniones entre homosexuales}

29/07/03 | La Iglesia iniciará mañana por orden del viejo Papa una movilización mundial de las conciencias católicas condenando en un documento oficial la legalización de las uniones civiles entre homosexuales. El severo cardenal alemán Josef Ratzinger,...

POLÍTICA | ENCUENTRO EN ROMA

\section{Bergoglio habló con el Papa}

06/07/03 | El arzobispo de Buenos Aires y cardenal primado, Jorge Bergoglio, mantuvo recientemente una prolongada reunión con el papa Juan Pablo II, con quien habría analizado la situación del país y de la Iglesia. El encuentro sorprendió en medios...

\section{POLÍTICA | LOS FESTEJOS DEL 25 DE MAYO}

\section{La idea de dos Tedéum abrió una polémica}

21/05/03 | La coincidencia de traspaso del mando con la conmemoración del 25 de Mayo suscitó una insólita situación. Por primera vez en casi 200 años de historia, podría haber dos Tedéum para celebrar la fecha patria. La única diferencia es que uno sería por...

\section{POLÍTICA}

\section{Duhalde, con Bergoglio}

12/05/03 | El presidente Eduardo Duhalde visitó ayer al arzobispo de Buenos Aires y cardenal primado, Jorge Bergoglio, para despedirse con motivo de la próxima finalización de su mandato. Al encuentro asistió también la esposa de Duhalde, Chiche. Sin embargo...

Desde que Bergoglio fue electo cardenal en 2001, Clarín y CL.COM comenzaron a publicar noticias sobre este líder religioso como uno de los principales candidatos papables: 


\section{Señalan a Bergoglio como el favorito para suceder al Papa \\ 03/12/02 | El semanario L'Espresso, uno de los más importantes medios periodísticos italianos, afirma en su último número que el favorito en la sucesión de Juan Pablo II es el cardenal argentino Jorge Bergoglio. Si hoy hubiera un Cónclave de los cardenales...}

EL MUNDO | NOMBRAMIENTO CLAVE EN EL VATICANO

\section{Un cardenal ultraconservador piloteará la sucesión}

papal

30/11/02 | El Papa nombró ayer al cardenal alemán Joseph Ratzinger Decano del Sacro Colegio Cardenalicio. Ratzinger es el Prefecto de la Congregación para la Doctrina de la Fe, el ex Santo Oficio, por lo que es considerado el guardián de la ortodoxia...

POLÍTICA

\section{Perfiles}

03/11/02 | CARDENAL JORGE BERGOGLIO: Nació en Buenos Aires y tiene 66 años. Es jesuita y obtuvo el título de técnico químico. Cuestiona severamente el neoliberalismo. Está a cargo transitoriamente del obispado castrense e integra varios organismos de la Santa...

\section{Incluyen a Bergoglio entre los candidatos a suceder al}

\section{Papa}

$\overline{\mathbf{2 4 / 0 5 / 0 2}}$ | El arzobispo de Buenos Aires se incorporó ayer a la lista oficiosa de "papables" al ser incluido como probable sucesor del anciano y enfermo Juan Pablo II. El cardenal jesuita Jorge Mario Bergoglio es dado como un candidato "en ascenso" por el...

En 2002, Clarín y CL.COM publicaron noticias sobre la participación de la Iglesia Católica argentina en la Mesa de Diálogo y sobre los casos de pedofilia del arzobispo de Santa Fe, Edgardo Storni:

SOCIEDAD | POSICION DEL EPISCOPADO

\section{Bergoglio habló del "caso Storni"}

28/09/02 | La Conferencia Episcopal reivindicó ayer la acción de la Justicia para aclarar la presunta responsabilidad del arzobispo de Santa Fe, monseñor Edgardo Storni, en las denuncias por abusos sexuales cometidos supuestamente contra seminaristas. Storni...

POLÍTICA | LA PELEA ENTRE EL GOBIERNO, LA IGLESIA Y EL EJERCITO

\section{Más cruces por la disputa sobre cómo y quién reparte alimentos}

$\mathbf{2 5 / 0 8 / 0 2}$ | La disputa entre el Gobierno, los militares y hasta la Iglesia, por la forma de encarar la asistencia alimentaria hacia los miles de argentinos que padecen hambre, escaló ayer con nuevas acusaciones y quejas de un sector del Gobierno hacia los...

SOCIEDAD | SOCIEDAD: SE CONMEMORO EL DIA DE SAN CAYETANO, PATRONO DEL PAN Y EL TRABAJO

\section{El cardenal Bergoglio llamó a "levantarse de las}

\section{ruinas"}

07/08/02 | En un país donde 6 millones de personas tienen problemas de empleo, con pasos lentos y avanzando cuatro cuadras cada dos horas, miles de peregrinos recorrieron ayer —como lo hacen cada 7 de agosto- más de veinte cuadras de cola para acercarse a la... 


\section{Una multitud con un reclamo en San Cayetano: pan y trabajo}

$\mathbf{0 6 / 0 8 / 0 2}$ | A las 12 de la noche de ayer, como en el primer minuto de cada 7 de agosto, las rejas de la Parroquia de San Cayetano se abrieron para que las manos de los peregrinos tocaran el vidrio que protege al patrono del trabajo y — según dicen en el...

OPINIÓN | EDITORIAL

\section{El peligro de la disolución nacional}

27/05/02 | El solo hecho de que la posibilidad de disolución nacional sea motivo de reflexión, marca la hondura de la crisis que atraviesa el país y la responsabilidad que le cabe a la dirigencia política y social para revertirla. En los últimos tiempos se...

POLITICA | EL GOBIERNO Y LA CRISIS: EN LA ANTESALA DE LA CUMBRE EN LA PAMPA

\section{Duhalde: "Mi gobierno tiene una debilidad congénita"}

26/05/02 | Habló de todo. Del corralito, la devaluación, el dólar. De los gobernadores, las elecciones y de su propia renuncia. Y apoyó sin reservas la severa advertencia que la Iglesia formuló el sábado. A pocas horas de iniciar la reunión con los...

RENUNCIA

\section{Duhalde: "Solo, sin apoyo, es muy difícil salir de esta crisis"}

25/05/02 | Eduardo Duhalde se declaró ayer como un presidente "solo, sin apoyo" y advirtió que en esa condición le "será muy difícil sacar al país de la crisis". Lo hizo en el espacio "Conversando con el Presidente", que va por Radio Nacional, grabado, todos...

POLITICA | EL TEMA DEL DOMINGO / EL GOBIERNO Y LA CRISIS: CONTUNDENTE PRONUNCIAMIENTO DE LA IGLESIA

\section{Bergoglio: "La disolución nacional está a las puertas"}

25/05/02 | En uno de los pronunciamientos más duros de los últimos tiempos de la Iglesia, el arzobispo de Buenos Aires y cardenal primado de la Argentina, Jorge Bergoglio, advirtió ayer que "el peligro de la disolución nacional está a nuestras puertas"....

POLITICA | OTRA ETAPA EN LA CRISIS: CON EL SELLO DE LA PASTORAL SOCIAL

\section{La Iglesia alienta voces críticas al FMI}

13/05/02 | Bajo la inspiración del presidente de la Pastoral Social, cardenal Raúl Primatesta, un grupo de empresarios y sindicalistas comenzó una discreta campaña a favor de un acotamiento de las exigencias del FMI y un proyecto de país productivo, que tenga...

POLITICA | EL NUEVO PLAN: NUEVO DOCUMENTO DE LOS OBISPOS

\section{La Iglesia criticó con dureza pero se queda en la Mesa del Diálogo}

27/04/02 | La Iglesia denunció ayer que la persistencia de "poderosos intereses sectoriales y corporativos" —a los que consideró como "la gran enfermedad que padecemos los argentinos"— impide que se concreten, a través de leyes, medidas y acciones, los...

POLITICA | EL NUMERO UNO DE LA IGLESIA ARGENTINA, FRENTE A LA CRISIS

\section{Bergoglio, un jesuita al que le gusta aparecer muy poco y decir bastante}

14/04/02 | Suele decirse que el jesuita — por su rigurosa formación— es un sacerdote acerca del cual nunca se sabe qué es lo que piensa realmente, una persona inescrutable; en fin, todo una incógnita. El arzobispo de Buenos Aires, Jorge Mario Bergoglio, de 64... 
POLÍTICA | LA CRISIS: COMPLICADA CONCERTACION SOCIAL

\section{Ultimo intento de la Iglesia para que el diálogo no fracase}

13/04/02 | Los tres obispos que integran la Mesa de Diálogo —la iniciativa que busca consensos para sortear la crisis - trabajan por estas horas a marcha forzada para lograr que la Casa Rosada, el Congreso, el Poder Judicial, los gobernadores, los partidos...

POLÍTICA

\section{Críticas de Bergoglio por la situación social}

10/04/02 | El arzobispo de Buenos Aires, cardenal Jorge Bergoglio, acusó ayer implícitamente al Gobierno porteño de pasividad ante un problema social, al revelar que "como resultado de un desalojo de un asentamiento, desde julio, hay en el barrio de Soldati...

POLITICA | LA CRISIS / ESCENARIO: LAS GESTIONES ENTRE FUNCIONARIOS, EMPRESARIOS Y SINDICALISTAS

\section{Ofensiva final de la Iglesia para lograr resultados en la} Mesa del Diálogo

30/03/02 | Los representantes de la Iglesia y las Naciones Unidas en la Mesa de Diálogo —el nucleamiento que busca consensos que contribuyan a sortear la crisis - iniciaron una fuerte ofensiva para que el Gobierno, el Congreso, el Poder Judicial y los diversos...

POLÍTICA | EL IMPACTO DE LAS MEDIDAS: REUNION DE DUHALDE CON LA CUPULA DEL EPISCOPADO

\section{La Iglesia será el ámbito para el diálogo político}

08/01/02 | El Gobierno dio ayer un paso clave en su proyecto de concertación social para afrontar la crisis económica y social, al lograr que la Iglesia ratificara su disposición a seguir colaborando con la implementación de un diálogo multisectorial tendiente...

SOCIEDAD | MAS DE 1.000 PERSONAS REZARON POR LA PAZ EN LA ARGENTINA

\section{Misa especial en la Catedral}

07/01/02 | Más de mil personas se reunieron ayer en la Catedral de Buenos Aires para rezar por la pacificación de la Argentina y la salida de la crisis económica, política y social. La misa celebrada por el arzobispo de Buenos Aires, cardenal Jorge Bergoglio-...

En 2001, la Iglesia Católica argentina avistaba el conflicto social y se posicionaba como una de las voces críticas del sector político, con lo cual hacía dos operatorias que ya hemos señalado: sustraer su pertenencia como actor político institucional y posicionarse por encima de los demás sectores -incluso de sus competidores religiosos- en la escena social y pública:

POLITICA | EL TEMA DEL DOMINGO / LA CRISIS DEL NUEVO GOBIERNO: LA POSICION DEL ARZOBISPO DE BUENOS AIRES

\section{Bergoglio reivindicó el cacerolazo del viernes}

30/12/01 | La Iglesia porteña reivindicó la protesta pacífica de vecinos de la Capital Federal, que entre el viernes y ayer a la madrugada protagonizaron un nuevo cacerolazo en demanda del fin del corralito bancario. $Y$ en repudio de ciertos funcionarios del...

\section{Críticas al plan desde la Iglesia}

04/12/01 | Las restricciones a las transacciones y la extensión de la bancarización dispuestas por el Gobierno cayeron como una bomba en la Iglesia. En los medios eclesiásticos era evidente anoche el malestar por las medidas, ya que se consideraba, sin... 
POLITICA I SI NO NOS UNIMOS, NOS VAN A TRAGAR UNO POR UNO, DIJO EL CARDENAL

\section{Fuertes críticas de Primatesta contra el FMI y el Banco Mundial}

30/09/01 | U n calificado miembro de la Iglesia cargó ayer contra los organismos financieros internacionales. El presidente de la Comisión de Pastoral Social, cardenal Raúl Primatesta, denunció que entidades "como el FMI y el Banco Mundial presionan" al país...

POLÍTICA | LA PROTESTA SOCIAL: CONTACTOS CON JEFES DEL EPISCOPADO

Todos recurren a la Iglesia para encauzar un diálogo 30/08/01 | El ruido de los bombos, redoblantes y petardos, que preanunciaban el multitudinario acto en Plaza de Mayo, se colaba ayer por las ventanas de los sobrios despachos de prominentes figuras de la Iglesia. Era un clima acorde con las reuniones que los...

POLITICA I EL IMPACTO DEL AJUSTE: DOCUMENTO DE LA CUPULA CATOLICA Y OTROS CULTOS CRISTIANOS

\section{Gestión de dirigentes religiosos para disminuir la} tensión social

01/08/01 | En un gesto conjunto inédito que revela hasta dónde preocupa el momento actual, la Iglesia católica y las demás confesiones cristianas tradicionales se comprometieron ayer a promover mancomunadamente un acercamiento entre los diversos sectores del...

POLÍTICA | LOS OBISPOS FRENTE AL SEPTIMO AJUSTE DEL GOBIERNO

La Iglesia avala la unidad nacional, pero no el recorte 23/07/01 | El Gobierno recibió esta semana una de cal y una de arena de parte de la Iglesia. Por un lado, celebró la acogida favorable que tuvo en el Episcopado el llamado de Fernando de la Rúa a la "unidad nacional" para sortear la crisis. Pero sufrió viendo...

\section{El obispo Bergoglio y el presidente de la DAIA piden por la paz}

13/07/01 | El arzobispo de Buenos Aires y cardenal primado, Jorge Bergoglio, y el presidente de la DAIA, José Hercman, hicieron ayer una exhortación conjunta contra la violencia y a favor de la convivencia pacífica ante la tensión social que vive el país. El...

POLITICA | INFORME ESPECIAL/ LA CRISIS SOCIAL: LOS OBISPOS ESPERARON EN VANO RESPUESTAS DEL GOBIERNO NACIONAL Y DEL PROVINCIAL

\section{La Iglesia avisó que venía la violencia}

24/06/01 | Los disparos que el domingo en General Mosconi acabaron con la vida de dos pobladores e hirieron a 24 gendarmes y 12 civiles confirmaron el temor que venían anticipando importantes miembros de la Iglesia: que la repetición de los cortes de rutas...

POLÍTICA | MENSAJE DE LA IGLESIA: CEREMONIA POR EL 25 DE MAYO

\section{La Iglesia advirtió sobre la crisis social y la violencia}

26/05/01 | La Iglesia siguió ayer con sus duras críticas a la dirigencia en general y a la política y económica en particular. Pero esta vez avanzó un paso más y les pidió que no demanden más sacrificios al pueblo si antes no los hacen ellos. Y, acaso para...

Acerca del Papa Juan Pablo II y el Vaticano también hubo otras noticias en CL y CL.COM: 
15/05/02 | Ante miles de fieles y 500 ex prostitutas que lo aclamaban en la audiencia general de los miércoles en la plaza de San Pedro en el Vaticano, el Papa Juan Pablo II, que el sábado cumplirá 82 años, salió al cruce nuevamente de las insistentes...

SOCIEDAD | CRECE EL ESCANDALO SEXUAL

\section{Abusos: el Papa citó a los trece cardenales de Estados Unidos}

15/04/02 | El papa Juan Pablo II convocó a una reunión a todos los cardenales de Estados Unidos (trece en total), tras los escándalos sexuales en los que están implicados sacerdotes de ese país. La reunión se hará durante la semana próxima. Los casos de abusos...

SOCIEDAD | A LOS 81 AÑOS, CONVOCO AL CONSISTORIO QUE PROBABLEMENTE SERA EL ULTIMO DE SU REINADO

\section{El Papa se despidió de sus cardenales}

26/05/01 | La Iglesia Católica ya no es la misma después de estos últimos cuatro días, en los que 155 de los 183 cardenales del Sacro Colegio venidos de todo el mundo hablaron de casi todo, convocados y estimulados por el viejo Papa, quien está en la parte...

\section{POLITICA | MENSAJE DE LA IGLESIA: PREOCUPACION DEL OFICIALISMO POR LA CRISIS SOCIAL}

\section{El Gobierno tomó nota de la advertencia}

26/05/01 | Anticipándose a las duras críticas realizadas ayer al mediodía en la catedral metropolitana por el cardenal Jorge Bergoglio, el presidente Fernando de la Rúa admitió que "está preocupado y le duele", la difícil situación social del país. Asimismo,...

POLÍTICA

\section{Advertencia en el momento justo}

15/04/01 | Fue la primera homilía del arzobispo Jorge Bergoglio en Pascuas como cardenal primado de la Argentina. Y la aprovechó para demostrar que no está dispuesto a diluir las implicancias concretas en la vida nacional del mensaje de la festividad religiosa...

POLÍTICA | PERFIL

\section{Bergoglio, un crítico de lo social}

15/04/01 | Se levanta poco después de las 8, almuerza solo o con su secretario, rara vez cena, y se acuesta alrededor de las 22. Habla alemán, italiano y también inglés. Enseñó literatura clásica pero, antes, se había recibido de técnico químico. Nació en...

POLITICA | LA IGLESIA Y LA POBREZA

\section{Bergoglio pidió por los excluidos}

13/04/01 | El arzobispo de Buenos Aires, cardenal Jorge Bergoglio, exhortó ayer a los sacerdotes a estar "en medio de nuestro pueblo fiel", especialmente "y con toda la ternura posible", cerca de "los que la sociedad excluye y olvida". Lo hizo en su homilía de...

\section{Una oración con el Cardenal Bergoglio}

31/03/01 | El presidente De la Rúa, acompañado por su esposa, Inés Pertiné, recibió ayer al cardenal Juan Bergoglio y le pidió "una oración para el pueblo argentino". Hablaron de la próxima audiencia con el Papa, del lanzamiento del seguro de desempleo y de la...

ECONOMÍA | EL NUEVO GOBIERNO: LOS OBISPOS, PREOCUPADOS POR LA SITUACION ECONOMICA Y SOCIAL

\section{La Iglesia sigue la crisis de cerca y promueve el}

\section{diálogo}

25/03/01 | En los peores momentos de la crisis en el Gobierno, que derivó en la entronización de Domingo Cavallo en Economía, más de un empinado miembro del Episcopado consideró la posibilidad de que la Iglesia ofreciera su asistencia para facilitar el diálogo...

\section{Escándalo por abusos sexuales}


21/03/01 | Un escándalo de grandes proporciones estalló ayer al ser publicados cuatro informes presentados a las autoridades de la Santa Sede que denuncian el fenómeno de curas y hasta obispos que abusan sexualmente de monjas, les obligan a tomar píldoras...

SOCIEDAD | SE REALIZARA HOY UNA GRAN CEREMONIA EN LA PLAZA DE SAN PEDRO

\section{Asumen 44 nuevos cardenales}

21/02/01 | En un nuevo récord de su largo pontificado de casi 23 años, el Papa "creará" hoy en la plaza de San Pedro, en un octavo Consistorio, a 44 nuevos cardenales que le jurarán fidelidad.

Entre ellos se encontrarán, vestidos de rojo púrpura, los...

\section{Austero homenaje oficial a los futuros cardenales}

15/02/01 | Los dos futuros cardenales argentinos no quieren que el Gobierno organice grandes festejos con motivo de su elevación al purpurado, el 21 y 22 de este mes en El Vaticano. Por eso, el arzobispo de Buenos Aires, monseñor Jorge Bergoglio, y el...

\section{Dicen que el sucesor del Papa podría ser un}

\section{latinoamericano}

23/01/01 | El nombramiento de 37 nuevos cardenales —entre los que están los obispos argentinos Jorge Mejía y Jorge Bergoglio— abre una pregunta: ¿cómo queda el equilibrio interno de fuerzas dentro de la Iglesia, y en especial del Sacro Colegio de Cardenales,...

POLITICA | PERFIL

\section{Bergoglio, el veloz ascenso de un jesuita}

22/01/01 | Monseñor Jorge Bergoglio, el arzobispo de Buenos Aires, porteño, de 64 años, es el más joven de los dos nuevos cardenales argentinos. Pero, además, es el que tuvo el ascenso más vertiginoso en la estructura eclesiástica. A comienzos de los años $90, \ldots$

\section{POLITICA | LA RELACION CON EL VATICANO: ENTREVISTA AL FLAMANTE CARDENAL PRIMADO}

\section{Bergoglio: Si el blindaje ayuda, debe ser bienvenido 22/01/01|}

POLITICA | LA RELACION CON EL VATICANO: ANUNCIO DE JUAN PABLO ॥

\section{Nombran cardenales a dos obispos argentinos}

22/01/01 | El Papa anunció ayer el nombramiento de 37 nuevos cardenales de la Iglesia en un Consistorio que se realizará el 21 de febrero próximo. Entre ellos están los argentinos Jorge

Bergoglio, arzobispo de Buenos Aires, y Jorge María Mejía, director del...

El corpus sobre la palabra clave cardenales dentro de la dimensión de análisis Vaticano parece ser uno de los más densos en la cantidad de noticias publicadas por Clarín y CL.COM.

Cobra magnitud, retrospectivamente, el nombre de Jorge Bergoglio como una de las principales figuras catalizadoras de los acontecimientos sucedidos en nuestro país y construidos como noticias sobre religión en el período 2001-2010, así como el vínculo que lo une a la sede católica y que lo llevará a conducirla en 2013.

\section{LA NACIÓN Y LN.COM}


De manera comparativa, en LN y LN.COM destacan las noticias referidas a la pedofilia por parte de sacerdotes de la Iglesia Católica y a la figura del Papa en la dimensión de análisis 'Vaticano'.

En este medio, las noticias relacionadas con las palabras clave tienen un anclaje mayor en lo informativo desde los títulos y subtítulos, respecto al medio anterior, y es una de sus características de estilo, que lo remitiría a la llamada "prensa blanca" o seria por oposición al sensacionalismo de la "prensa amarilla" (Steimberg, 2013: 167-176).

\section{El Papa analiza los casos de abuso junto a cardenales del mundo}

...CIUDAD DEL VATICANO.- Ciento cincuenta cardenales de todo el mundo se encuentran reunidos...primera vez que un número tan elevado de cardenales analizarán junto al Pontífice escándalos...aprovechando la presencia en Roma de esos cardenales, venidos para el consistorio que se celebrará...

19.11.2010 | 02:30 | Cultura | lanacion.com

El Papa se reunió con cardenales para hablar de los abusos sexuales

CIUDAD DEL VATICANO.- Los cardenales del mundo iniciaron hoy una cumbre...papa Benedicto XVI convocó a los cardenales a un día de reflexión antes de una...mañana consagrará a 24 nuevos cardenales, los príncipes de la iglesia...

19.11.2010 | 02:28 | Exterior | lanacion.com

$\underline{\text { La atención ahora está puesta en los cardenales }}$

...período preparatorio antes de que los cardenales se reúnan en un cónclave que comenzará...la atención estará puesta sobre los cardenales que elegirán al próximo papa. Cada...especial oficiada principalmente por cardenales cuyas voces serán escuchadas atentamente...

09.04.2005 | Exterior | Edición impresa

\section{Los cardenales comienzan a revelar los secretos de la elección}

...silenciosa, ajeno al clamor del resto de los cardenales que, vestidos de púrpura, aplaudían...la mayoría, sin faja púrpura- los cardenales que lo eligieron comienzan a salir, bolsito...que representan los dos tercios de los cardenales electores. "Obtuvo más votos de...

21.04.2005 | Exterior | Edición impresa

El Papa convocó a hablar de pedofilia

...corresponsal).- En un año marcado a fuego por el escándalo de abusos de niños por parte del clero, el Papa decidió invitar a los cardenales de todo el mundo a hablar sobre este y otros temas el próximo viernes 19 en el Vaticano, un día antes del consistorio en el...

09.11.2010 | Cultura | Edición impresa 
Las informaciones acerca de la elección de Ratzinger y de la designación de nuevos cardenales en 2001, 2005, 2007 también estuvieron presentes en LN y LN.COM:

\title{
El Papa designará 24 cardenales
}

\begin{abstract}
...que el mes próximo nombrará 24 nuevos cardenales, de los cuales 20 son electores, es...italiana: en la lista hay ocho nuevos cardenales electores de la península. EI Papa designó...consistorio de Benedicto XVI, que designó cardenales en febrero de 2006 y en noviembre de...
\end{abstract}

\subsubsection{0 | Cultura | Edición impresa}

\section{El Colegio Cardenalicio prepara la elección papal}

\begin{abstract}
...deberá seleccionar al próximo papa, los cardenales del Sacro Colegio comenzaron hoy conversaciones...el segundo día consecutivo que los cardenales hablaron sobre las finanzas de la Iglesia...conversaciones, y se limitó a decir que los cardenales "comenzaron un intercambio de ideas...
\end{abstract}

12.04.2005 | 01:45 | Exterior | lanacion.com

\section{En el cónclave, las divisiones van más allá de la ideología}

\begin{abstract}
...conservadora y el ala progresista de los 117 cardenales electores, se ríe. Ojalá fuera tan...Pablo II. No es fácil separar a los cardenales en distintos grupos, de acuerdo con....analistas no es correcto, ya que los cardenales serán lo uno o lo otro según el tema...
\end{abstract}

\subsubsection{5 | Exterior | Edición impresa}

Otras noticias refirieron a diversas reuniones de los cardenales en el Vaticano o a las finanzas de la Iglesia Católica:

\section{Los números del Vaticano, al rojo vivo}

...embajadas de los países. En total trabajan 2762 personas. En un comunicado dado a conocer hace una semana por el Consejo de los Cardenales para el Estudio de los Problemas Organizativos y Económicos de la Santa Sede, las arcas vaticanas tuvieron durante 2009 entradas...

11.08.2010 | 12:32 | Economía | lanacion.com

\section{La Santa Sede perdió más de 4 millones de euros por la crisis}

...resultados del Estado de la Ciudad del Vaticano, el Consejo de Cardenales para el estudio de problemas organizativos y económicos de la...económicos fueron aprobados en la 45 reunión del Consejo de Cardenales para el estudio de problemas organizativos y económicos de...

10.07.2010 | 03:52 | Exterior | lanacion.com 
Las ceremonias de despedida, luego de la muerte de Juan Pablo II, y su pronta beatificación también fueron noticia en este medio:

\title{
Comenzó el largo adiós al Papa
}

...comenzará la primera reunión de la congregación general de cardenales para decidir los detalles del funeral solemne, que muy probablemente...el 22 de abril, y de los eventuales papables, decenas de cardenales, junto a miles de fieles, iban llegando a esta capital...

\subsubsection{5 | Exterior | Edición impresa}

\section{Abren al público la tumba del Papa}

...quedaría cubierto en cuestión de minutos", se indicó. Los cardenales se anticiparon. Ayer, en imponente procesión, desaparecieron...es un hecho es que las colas por verlo acompañarán a los cardenales rumbo al cónclave. Y eso, otra vez, será un mensaje para...

\subsubsection{5 | Exterior | Edición impresa}

\section{Benedicto XVI inició su pontificado con un mensaje optimista}

...personas, entre ellas jefes de Estado y de gobierno. El Papa llegó a las 10 (5 de la Argentina) seguido por una procesión de cardenales provenientes de la basílica. En la homilía, más optimista y menos severa con respecto a otros escritos del antaño cardenal...

\subsubsection{5 | 12:35 | Exterior | lanacion.com}

\section{Juan Pablo Il podría llegar a santo este año}

...y desde que se oyó el grito de la plaza, "¡Santo ya!", el día de su último adiós-, fue un tema que también los cardenales trataron durante las congregaciones generales de estos días de sede vacante. En una de estas reuniones previas al cónclave...

12.04.2005 | Exterior | Edición impresa

Entre 2008 y 2009, La Nación y LN.COM publicaron varias notas sobre declaraciones del Papa Benedicto XVI:

\section{Holocausto: Merkel pidió al Papa que se pronuncie}

\begin{abstract}
...negacionistas antes de decidir levantarle la excomunión junto a otros tres obispos. Mientras aumenta el número de teólogos, cardenales y obispos de países europeos alarmados por el escándalo, según pudo saber LA NACION, las peores reacciones llegan desde...
\end{abstract}

04.02.2009 | Cultura | Edición impresa

\section{El Vaticano quiere misas tradicionales}


...tradicional y solemne. Según reveló ayer II Giornale, en una reunión reservada en marzo pasado en el Vaticano, un grupo de cardenales y obispos miembros de la Congregación para el Culto Divino aprobó casi por unanimidad una serie de propuestas que apuntan...

\subsubsection{9 | Cultura | Edición impresa}

\section{El Pontífice pidió a los hispanos que superaran el "pesimismo"}

...apareció Benedicto XVI a bordo del papamóvil, que dio una vuelta completa al predio con sus ventanas bajas, mientras incluso los cardenales sacaban fotos. Pronto comenzaron los gestos hacia los hispanos. Con la primera lectura, de los Hechos de los Apóstoles...

\subsubsection{8 | Exterior | Edición impresa}

\section{El Papa pidió que no se repitan "barbaridades" como las de la II Guerra Mundial}

...y visitó la sala del Cónclave del Palacio de los Papas, donde en 1268 el gobernador de la ciudad encerró con llave a los cardenales para que eligieran a un nuevo Pontífice, ya que los purpurados habían dejaron vacante la sede apostólica durante más de...

06.09.2009 | 09:21 | uutura | lanacion.com

\section{EI Papa reclamó una "urgente" reforma de la ONU y pidió "ética" en la economía}

...La colaboración de la familia humana" y "Desarrollo de los pueblos y de la técnica". La encíclica la presentaron los cardenales Renato Raffaele Martino, presidente del Consejo Pontificio Justicia y Paz, y Paul Josef Cordes, presidente del Consejo Pontificio...

\subsubsection{9 | 07:57 | Cultura | lanacion.com}

\section{EI Papa llamó a reconciliarse con la Iglesia}

...número de los que cada año abrazan la fe católica". El estadio donde se desarrolló la popular misa, celebrada junto a 14 cardenales, 250 obispos y 1300 sacerdotes, se llenó desde muy temprano, con fieles que arribaron desde todas las diócesis de Estados...

17.04.2008 | 11:59 | Exterior| lanacion.com

\section{Invocación por la paz, a 70 años de la querra}

...San Egidio, con el lema de "Religiones y culturas en diálogo. El espíritu de Asís en Cracovia". Asistirán otros diez cardenales -entre ellos, el argentino Leonardo Sandri- y el patriarca melquita de Antioquía, por los católicos. Estarán también..

\subsubsection{9 | Cultura | Edición impresa}

Varias notas anticipaban la posibilidad de que Bergoglio fuera papable:

\section{El candidato: Bergoglio, il papabile}

...Bergoglio, ante la vista del Papa y de los cardenales de todo el mundo. Esa aparición pública...distingue por encima de muchos otros cardenales. "Es una persona silenciosa. Pero...elección, hay que señalar que otros cardenales han tenido una presencia internacional más... 
De todas maneras, la figuración textual de Bergoglio en las noticias sobre cardenales en LN y LN.com no es como en CL Y CL.COM. Pareciera que su enunciación acerca de la figura de Bergoglio, lo convertía en un actor social cercano al diario La Nación. En cambio, el tratamiento informativo de la relación de los cardenales con cada papado ocupa un importante espacio en la sección de Internacionales:

\title{
Benedicto XVI, cerca de autorizar la misa en latín
}

\author{
...fue dado a conocer a algunos obispos y cardenales con los que el papa acababa de \\ entrevistarse...de una hora aproximadamente" con los cardenales y obispos presentes que, \\ según información...A fines del año pasado, todos los cardenales señalaron a Benedicto XVI sus \\ reticencias... \\ 28.06.2007 | 01:35 | Cultura | lanacion.com
}

\section{Primera homilía de Benedicto XVI}

\begin{abstract}
....ayer en la Capilla Sixtina con los 114 cardenales que participaron del cónclave...través del voto de los venerados padres cardenales, me ha llamado a suceder a este gran....Espíritu Santo. "A ustedes, señores cardenales, con ánimo grato por la confianza...

21.04.2005 | Exterior | Edición impresa
\end{abstract}

Ratzinger defendió la ortodoxia católica amenazada por las "modas ideológicas"

\begin{abstract}
...desde el Aula de las Bendiciones. Los cardenales ocuparon sus puestos en las mesas instaladas...texto del juramento por el cual los cardenales se comprometen a mantener en secreto...sin aceptar presiones externas. Los cardenales desfilaron entonces para prestar juramento...

19.04.2005 | 03:00 | Exterior | lanacion.com

Los desafíos que enfrenta el Vaticano en la era de la globalización

...siguientes a la muerte del Pontífice. Los cardenales con derecho a voto se dividirán inevitablemente...siglo. El transporte aéreo facilita a cardenales y obispos visitar Roma y ayudó a internacionalizar...la Curia -menos de un tercio de los cardenales es italiano-, pero también en que...

02.04.2005 | Exterior | Edición impresa
\end{abstract}

La figura de Benedicto XVI tras la muerte de Juan Pablo II fue uno de los motivos temáticos recurrentes en las noticias de LN y LN.COM por las desavenencias que suscitaba su elección como sumo pontífice: 


\title{
Un doctrinario para continuar la obra de Juan Pablo II
}

...defendió la ortodoxia del catolicismo y alertó a los otros 114 cardenales electores que no debían seguir tendencias modernas ateas...II que, precisamente, fue quien designó a 114 de los 117 cardenales electores. En contra advierten de su edad avanzada -cumple...

19.04.2005 | 01:52 | Exterior | lanacion.com

\section{Decepción y reservas de algunos sectores}

...estaba a la derecha. Pero se vio que los cardenales estaban todos inclinados por la continuidad...decisión, fruto de la elección de los cardenales. Pero habrá dificultades para amar a...afirmó que la decisión de los 115 cardenales reunidos en el cónclave fue una "decepción...

\subsubsection{5 | Exterior | Edición impresa}

Entre los papables, también LN y LN.com mencionaban nombres que finalmente no fueron electos; uno de los cardenales favoritos era el italiano Tettamanzi, otro el brasileño Humes, el colombiano Hoyos, entre otros:

\section{Los posibles sucesores}

...expectativas. Actualmente el Sacro Colegio está compuesto por 117 cardenales de menos de 80 años, límite de edad para elegir en caso de...papabili" -como dicen los italianos- también aparecen dos cardenales latinoamericanos: el colombiano Darío Castrillón Hoyos...

02.04.2005 | 06:20 | Exterior | lanacion.com

\section{Ratzinger y Sodano, favoritos en las apuestas sobre el nuevo papa}

\begin{abstract}
...elegido papa es de 77 , los dos tercios más uno de los 115 cardenales electores que han asegurado su presencia en este primer cónclave...diario II Tempo, Ratzinger contaría con los apoyos de los cardenales más próximos a Juan Pablo II, desde el presidente de la...
\end{abstract}

13.04.2005 | 09:03 | Exterior | lanacion.com

Uno de los rasgos del estilo de LN y LN.COM es el de publicar notas y columnas de opinión que plantean una distancia -a veces analítica, a veces crítica, otras veces ambasrespecto de la información de actualidad. Incluso en temáticas propias de las noticias sobre religión. Tras la muerte de Juan Pablo II este medio publicó el siguiente artículo del teólogo Leonardo Boff:

\section{El Papa que detuvo las reformas que necesitaba la Iglesia}

...muchos cristianos a ingresar en los movimientos sociales de liberación y hasta en frentes armados, mientras numerosos obispos y cardenales asumieron un papel destacado en el 
combate a las dictaduras militares y en la defensa de los derechos humanos, entendidos principalmente...

05.04.2005 | Exterior | Edición impresa

En este tipo de notas observamos algunos rasgos del estilo periodístico interpretativo de LN y LN.COM, al describir y explicar el funcionamiento de la curia vaticana y el rol de cada uno de los cardenales. Este rasgo suele compartirlo con Página/12 y P12.COM, y, a su vez, lo diferencia del estilo de la supuesta claridad y concisión en lo informativo, que se adjudican Clarín y CL.COM:

\section{Giovanni Battista Re: el candidato que mejor conoce cómo funciona el Vaticano}

...Re, de 71 años, no sólo fue y es considerado por los especialistas uno de los tres mandamás de la Iglesia junto con los cardenales Ratzinger y Sodano, sino que desde hace años es, pese a su acostumbrado bajo perfil, uno de los protagonistas principales...

\subsubsection{5 | Exterior | Edición impresa}

\section{El Papa se planteó renunciar tras el Jubileo}

...principal sinagoga de la capital italiana, en 1986. Sin legado material. En la carta, leída ayer por la congregación de cardenales, el Santo Padre no deja legado material alguno y solicita que sus notas personales sean quemadas. Horas después de conocerse...

07.04.2005 | 12:02 | Exterior | lanacion.com

\section{Tarcisio Bertone}

...pastoral, un agudo sentido del humor y un excelente rapport con los jóvenes, lo que lo hace atractivo ante los ojos de los cardenales que buscan un Ratzinger más joven y menos intransigente. De carácter extravertido, el cardenal es un fanático seguidor...

\subsubsection{5 | Exterior | Edición impresa}

\section{Sandri podría llegar a cardenal en junio}

...vaticanista del diario La Stampa , que calculó que, ateniéndose a las reglas de Pablo VI -que impuso el límite de 120 cardenales electores (menores de 80 años)-, el pontífice alemán podría designar unas quince nuevas púrpuras, entre las cuales...

\subsubsection{7 | Cultura | Edición impresa}

Otra nota preanuncia una dimisión que no fue la de Juan Pablo II pero sí a quien él había consultado en el año 2000, el entonces cardenal Joseph Ratzinger quien luego renunció al trono de Pedro. 
La noticia cuenta vicisitudes en la vida de Juan Pablo II y hace comentarios sobre un libro que revelaba infidencias de quien fuera su secretario. Otra coincidencia con Ratzinger aunque sin los escándalos suscitados por las revelaciones del mayordomo de Benedicto XVI y por los Vatileaks, las filtraciones de información confidencial en internet a través del sistema creado por Julian Assange.

\section{Confirman que Juan Pablo II estuvo a punto de renunciar}

...seriamente en una renuncia al trono de Pedro. "El se preguntó si, análogamente a lo que Pablo VI había establecido para los cardenales de más de 80 años, que están excluidos de la elección pontificia, también el papa no debía renunciar a su cargo al cumplir...

02.02.2007 | Cultura | Edición impresa

Respecto del caso Baseotto, en 2005 LN Y LN.COM publicaban:

\section{"El caso Baseotto ya está terminado"}

...relación Gobierno-Vaticano a partir del recambio papal. Desde la óptica oficial, ni la ratificación en sus cargos de los cardenales con mayor influencia en la estructura vaticana (sobre todo la de Angelo Sodano, secretario de Estado y de buena relación...

\subsubsection{5 | Política | Edición impresa}

\section{Baseotto: réplica de Bergoglio al Gobierno}

...El único que designa a los obispos en la Iglesia es el Papa, respondió Bergoglio, arzobispo de Buenos Aires y uno de los cardenales según reconocidas publicaciones internacionales que más votos tuvo en el cónclave en que se eligió a Joseph Ratzinger para...

26.04.2005 | Política | Edición impresa

En 2003, LN.com hacía referencia a diversos acontecimientos que involucraban a los cardenales en su relación con el Papa Juan Pablo II y el Vaticano:

\section{El Vaticano y sus vecinos}

...nombramiento de más de treinta nuevos cardenales, y quién sabe si, como ya pasó otras veces, el número de los cardenales no será aún mayor. De esto se alegran...honor de vestir, además de a muchos cardenales, al mismísimo obispo de Roma, su..

14.10.2003 | Opinión | Edición impresa

\section{El Papa no viajará más al exterior}


...próximo, cuando asumirán 31 nuevos cardenales. "El Papa siente que se está muriendo...razones y prefirió aprovechar que los cardenales de todo el mundo ya habían sido...pontificado. Al respecto, entre los 31 cardenales designados Juan Pablo II se reservó...

\subsubsection{3 | Cultura | Edición impresa}

\section{Un argentino es hoy "la voz" del Papa}

...sostén, a tres personas: Sandri y los cardenales Joseph Ratzinger -prefecto de la Congregación...hizo más fuerte la presencia de los cardenales Ratzinger y Sodano, y del arzobispo Sandri...preocupación, trascendió ayer que un grupo de cardenales mayores de ochenta años -que no tienen...

\subsubsection{3 | Exterior | Edición impresa}

\section{El aniversario de su elección, la próxima prueba del Papa}

...octubre y que reunirán aquí a todos los cardenales del mundo. En momentos de signos de desconcierto...mismo día, horas más tarde, los cardenales de todo el mundo, junto con los presidentes...menos en una oportunidad para que los cardenales se conozcan mejor y charlen sobre candidaturas...

\subsubsection{3 | Cultura | Edición impresa}

\section{"Sean pastores, no burócratas", reclamó a los obispos del mundo}

...en una fecha clave, ante todos los cardenales del mundo, sacerdotes y 7000 fieles...que bajo y a diferencia de muchos cardenales que están aquí en una virtual "campaña...filas destinadas a los cerca de 150 cardenales presentes en Roma. Pero enseguida...

\subsubsection{3 | Exterior | Edición impresa}

En 2002:

\section{En medio de rumores, el Papa cumple hoy 82 años}

...1983, fue nuevamente mencionada anteayer por dos prominentes cardenales, el alemán Joseph Ratzinger, y el hondureño Oscar Rodríguez...Divina Comedia. Ahora el tema no es tabú, y son varios los cardenales que han hecho alusión a la posible dimisión. Según Marco...

\subsubsection{2 | Cultura | Edición impresa}

\section{Bergoglio seduce a Roma por su simplicidad, austeridad y espiritualidad}

...Pero Bergoglio no es un Karol Wojtyla, y creo que los cardenales no quieren elegir a alguien que repita las peculiaridades...espiritualidad." "Bergoglio no es un Karol Wojtyla y creo que los cardenales no quieren elegir a alguien que repita las peculiaridades de...

\subsubsection{2 | Cultura | Edición impresa}

\section{El caso Storni sobrevoló Roma}

...reunió al Santo Padre con toda la delegación argentina. En abril último Juan Pablo II fue categórico al convocar a los cardenales norteamericanos y anunciar la nueva política, de tolerancia cero, frente a estos escándalos. "La gente debe saber que... 
El nombramiento del arzobispo de Buenos Aires como cardenal el 21 de febrero de 2001 y la crisis argentina de fines de ese año hicieron que la atención pública mediática se concentrara en la figura del nuevo cardenal Bergoglio quien, a su vez, lideró la llamada Mesa del Diálogo Argentino y fue presidente de la Conferencia Episcopal Argentina dos períodos consecutivos:

\section{Bergoglio: el país debe apelar a sus reservas morales}

...contento con la designación de dos cardenales argentinos, eso es lo que siento. El Papa nos miró bien: dos cardenales de un mismo paísÉ es mucho...nombramientos aumentó el número de cardenales de América latina. ¿Crece la posibilidad...

\subsubsection{1 | Cultura | Edición impresa}

\section{"El país está dañado por los privilegios"}

...arriba", dijo el cardenal Bergoglio, que anteayer regresó de Roma, donde participó junto a Juan Pablo II del consistorio de cardenales más numeroso en la historia de la Iglesia. El arzobispo de Buenos Aires recordó que "no es cosa novedosa ni comienza en...

\subsubsection{1 | Cultura | Edición impresa}

\section{Debate crucial}

...apostólica, verdadera agenda del encuentro que hoy inician los cardenales. Trazar el rumbo evangelizador en esta época de globalización...se reunirá en octubre en la misma Aula que hoy ocupan los cardenales para discutir, precisamente, sobre el rol y la figura del..

\subsubsection{1 | Opinión | Edición impresa}

\section{Según Jorge Mejía, la Argentina va por el buen camino}

...visitar a familiares. Ayer participó de una misa junto con los cardenales Jorge Bergoglio y Juan Carlos Aramburu, otros nueve obispos...último, Jorge Bergoglio y Jorge Mejía fueron designados cardenales. Desde entonces, este último, que se radicó en Roma hace...

\subsubsection{1 | Cultura | Edición impresa}

\section{Los obispos y la crisis política}

...exclusión social, los obispos argentinos iniciarán hoy su primer plenario del siglo, durante el cual recibirán a los dos nuevos cardenales Jorge Bergoglio y Jorge Mejía, quienes en un par de semanas más participarán en Roma del consistorio convocado por Juan Pablo...

\subsubsection{1 | Opinión | Edición impresa}

\section{De la Rúa condenó una vez más el aborto}

...didáctica dispuesta en el vestíbulo de la universidad para recordar la historia de la casa. Por esos claustros pasaron los cardenales argentinos Raúl Primatesta y Jorge Mejía, y los obispos Estanislao Karlic, Desiderio Collino y Emilio Bianchi di Cárcano... 


\section{PÁGINA/12 Y P12.COM}

La ironía, la sátira y el sarcasmo en títulos y bajadas que plantean referencias a la literatura, el arte, el psicoanálisis y la filosofía, muchas veces bajo la forma del humor y de la comicidad, predominan como rasgos estilísticos del tratamiento informativo que Página/12 y P12.COM hacen de las noticias sobre religión.

Estas características propias de su manera de hacer (Steimberg, 1993, 2013) también demuestran que el diario de papel y el digital no pueden dejar de tratar esas informaciones de un modo socialmente compartido, tal vez, por la mirada "agnóstica" que plantea este medio en supuesta representación de un sector social que se considera parte del "progresismo" argentino contemporáneo.

En cuanto a la cantidad de noticias es sensiblemente menor en P12 y P12.COM respecto de los otros dos medios indagados. Este rasgo cuantitativo puede relacionarse con el tamaño y el volumen general de noticias que publica este periódico, al publicar una menor cantidad de páginas en la edición de papel y un menor volumen de noticias en la edición digital.

Los temas de las noticias suelen ser, sin embargo, similares en los contenidos específicos a los tratados por los medios que describimos antes: en 2010 las denuncias sobre curas pedófilos en la Iglesia Católica, el debate y sanción de la llamada ley de matrimonio igualitario en la Argentina; en 2009 las declaraciones de Benedicto XVI sobre la pobreza y la polémica con los lefebvristas negacionistas del Holocausto:

\section{"PERDÓN POR TAN LARGO SILENCIO"}

El obispo Miguel Asurmendi remarcó el "injustificable silencio de los medios oficiales de nuestra Iglesia" ante sus muertos. Es un primer gesto de reconocimiento de la alta jerarquía eclesiástica de los crímenes de la dictadura.

PRINCIPAL |EI mundo |프 |Lunes, 13 de julio de 2009

\section{EL DISCURSO DEL PAPA NO CONVENCIÓ}

Benedicto XVI fue criticado por no nombrar a los nazis como asesinos de la Shoá. Ayer, el Sumo Pontífice tuvo una agenda apretada: visitó el Muro de los Lamentos y el Templo de Jerusalén; además se reunió con líderes religiosos.

PRINCIPAL IEI mundo 国 |Miércoles, 13 de mayo de 2009

La agenda mediática de temas e incluso de algunos contenidos específicos recurrentes en las noticias es coincidente en los tres medios de comunicación indagados. En 
cambio, se diferencian por el tratamiento que cada uno hace de la información de la actualidad social.

Entre los contenidos específicos existe una diferencia en el tratamiento de lo sucedido con los lefebvristas de P12 y P12.COM, respecto a CL.COM y LN.COM, que se conectaba con el espacio concedido a los derechos humanos y el lugar que le otorgaba al gobierno kirchnerista en esa política: la falta de condena de Benedicto XVI al Holocausto y las declaraciones del obispo Richard Williamson, que mencionaban las noticias anteriores:

\section{SU RUTA}

La presidente CFK dispuso que el obispo negacionista Richard Williamson deje el país en diez días por sus "despreciables declaraciones antisemitas". El antisemitismo es una aberración y la negación del Holocausto agrede a la comunidad judía y a toda la sociedad, dice la resolución.

PRINCIPAL |EI país 国 |Viernes, 20 de febrero de 2009

\section{LA ÚNICA VERDAD}

La negación del Holocausto es coherente con la negación de cualquier verdad fuera de la Iglesia Católica, que el papa Ratzinger viene practicando en forma sistemática. Cómo repercutirá en el catolicismo argentino el indulto a los lefebvristas, que asesoraron a la dictadura militar. A medio siglo del Concilio y en la fecha de conmemoración del Holocausto, ningún pedido de disculpas disminuye la claridad del mensaje.

PRINCIPAL |티 país 표 |Domingo, 1 de febrero de 2009

\section{EL PAPA Y LOS LEFEBVRISTAS}

\section{EGO TE ABSOLVO}

PRINCIPAL | $\underline{\text { Sociedad }}$ [I] |Miércoles, 28 de enero de 2009

La atención a los acontecimientos regionales ligados a América Latina, al Cono Sur y, en particular, al catolicismo del Movimiento de Sacerdotes para el Tercer Mundo es privilegiada por P12.COM entre sus noticias:

\section{"LUGO FUE UN REVÉS PARA EL VATICANO"}

A cuatro días de la asunción del ex obispo Fernando Lugo como presidente de Paraguay, el padre De Paula Lima Alonso señala que este caso puede ser "un comienzo de cambios que estén conectados con la Iglesia".

PRINCIPAL |EI mundo |묘 |Lunes, 11 de agosto de 2008

\section{LA CIA VIGILÓ A LOS CURAS TERCERMUNDISTAS}

Según un documento desclasificado esta semana, a fines de los '60 la CIA estaba obsesionada con la posibilidad de una alianza entre el comunismo y la Iglesia en la región. Para la agencia, el énfasis que ponían los curas tercermundistas en la justicia social era un peligro.

PRINCIPAL |티 mundo 표 |Domingo, 1 de julio de 2007 
También son publicadas en P12 y P12.COM entrevistas con analistas y especialistas sobre el fenómeno religioso:

\author{
“ENTRAR EN EL VATICANO ES COMO LAVARSE EN UN MAR DE HIJOPUTEZ” \\ Vino a Buenos Aires a presentar su último libro, El poder y la gloria, un estudio lapidario del \\ reinado de Juan Pablo II. Es un experto en la Iglesia como institución del poder, de sus \\ complicidades y de funcionarios como Pío Laghi, el nuncio durante la dictadura, "que no sé cómo \\ hace para dormir con su conciencia, no debe tener una". \\ PRINCIPAL |Dialogos |묘 |Domingo, 9 de diciembre de 2007

\section{EL PAPA DE LA GENTE}

David Yallop ya había sacudido el mundo vaticano al escribir la hipótesis del envenenamiento de Juan Pablo I. Ahora no llega a tanto, pero revisa de un modo hipercrítico la entronización de Karol Wojtyla como el Papa de Papas.

니BROS 묘 |Domingo, 2 de diciembre de 2007

Respecto a cómo funciona la Iglesia Católica y el Vaticano, en particular, este medio también suma al estilo irónico el componente incluido de la crítica:

\title{
DOS CARDENALES ARGENTINOS
}

Uno es un viejo amigo de Ratzinger que recibe un reconocimiento a su trayectoria. El otro es un viejo insider del Vaticano con la edad suficiente para ser uno de los electores papales.

PRINCIPAL |티 país 国 |Domingo, 25 de noviembre de 2007

\section{DOS NUEVOS CARDENALES ARGENTINOS FUERON NOMBRADOS POR BENEDICTO XVI}

\begin{abstract}
Los arzobispos Leonardo Sandri y Estanislao Karlic fueron designados cardenales. El primero mantiene sólidos vínculos con Esteban Caselli, el operador del menemismo en el Vaticano.
\end{abstract}

PRINCIPAL |EI país |⿴囗口 |Jueves, 18 de octubre de 2007

\section{LA ALEGRÍA DEL DIABLO}

La última monarquía absoluta del mundo explica cómo debe ser la democracia y un club de sexagenarios célibes fija pautas sexuales y maritales para los jóvenes. El documento del Episcopado argentino oculta la conmoción causada en la Iglesia Católica por las mutilaciones vaticanas al documento del CELAM aprobado en Aparecida, Brasil. También el Comando Sur da clases de democracia a las fuerzas de seguridad de Sub América.

PRINCIPAL |티 país [표 |Domingo, 26 de agosto de 2007

FERNANDO VALLEJO HABLA DE “LA PUTA DE BABILONIA”, UNA PODEROSA

ACUSACION CONTRA LOS FANATISMOS RELIGIOSOS

“ES LA HORA DE PROSCRIBIR A ESTA INSTITUCIÓN CRIMINAL”

ESPECTACULOS |LITERATURA [표 |Domingo, 3 de junio de 2007

En 2007 la cumbre de la CELAM en Aparecida, Brasil, fue un acontecimiento relevante para P12 y P12.COM: 


\section{CUMBRE DE OBISPOS BAJO LA MIRADA DE BENEDICTO}

Con la presencia del Papa, obispos, teólogos y cardenales del Vaticano se celebrará la quinta conferencia general del Celam. Bergoglio encabeza la delegación argentina. Se espera una reafirmación de la postura de la Iglesia en contra de la práctica del aborto, la defensa de la familia y el rescate de las "raíces católicas".

PRINCIPAL IEI mundo 且 |Domingo, 13 de mayo de 2007

\section{BENEDICTO VIENE A FRENAR EL ÉXODO}

Además de canonizar al primer santo brasileño, hablar en contra del aborto, inaugurar una conferencia de obispos y reunirse con Lula, el Papa quiere frenar la sangría de la mayor feligresía católica en el mundo a manos de cultos protestantes.

PRINCIPAL IEI mundo 且 |Miércoles, 9 de mayo de 2007

En 2006 este medio publicó distintas noticias; tal vez entre las más llamativas, P12.com destacaba con sorna la supuesta refutación al filósofo Friedrich Nietzsche que habría hecho Benedicto XVI en una de sus encíclicas papales, 'Deus Caritas Est', aunque también estaba relacionado con su estilo "intelectual” y progresista, con la hipótesis sobre sus destinatarios posibles como lectores interesados en las referencias hacia la cultura:

\section{UN AÑO DEL PAPA RATZINGER}

La diferencia entre el poderoso obispo de Juan Pablo II y Benedicto XVI es imperceptible: el nuevo pontífice sigue las ideas que su antecesor en el Vaticano había aceptado.

PRINCIPAL |EI mundo |⿴囗玉 |Domingo, 23 de abril de 2006

EL PAPA NOMBRÓ A QUINCE CARDENALES, ENTRE ELLOS UNO ES “CASI ARGENTINO” Benedicto XVI anunció ayer los nombres de los primeros cardenales que nombra en su pontificado. En la lista figura un esloveno, ex arzobispo de la capital de ese país que vivió su adolescencia y juventud en el conurbano bonaerense, donde cursó los primeros años del seminario.

PRINCIPAL |EI mundo 国 |Jueves, 23 de febrero de 2006

\section{EL PAPA QUE DEFIENDE A (SU) EROS Y LE CONTESTA A FRIEDRICH NIETZSCHE}

Benedicto XVI publicó ayer su primera encíclica, Deus caritas est, en la que exalta el poder del amor, reivindica el eros y refuta a Nietzsche. También critica la doctrina marxista.

PRINCIPAL |티 mundo |⿴囗玉 | Jueves, 26 de enero de 2006

En 2005, luego de la muerte de Juan Pablo II, P12 y P12.COM publicó esta entrevista a un especialista en información sobre el Vaticano:

“POR PRIMERA VEZ UN PAPA HA ELEGIDO A SU SUCESOR” Josef Ratzinger fue elegido mucho antes del cónclave. La decisión le vino de un Papa antes de morir: Juan Pablo II. Y la seguridad mundial está peor, según el vaticanólogo y experto antiterrorista Eric Frattini.

PRINCIPAL |티 mundo 国 |Miércoles, 28 de septiembre de 2005 


\section{BERGOGLIO, CANDIDATO A NÚMERO DOS DEL VATICANO}

En Roma y en Buenos Aires se cuentan los datos para ver si el arzobispo porteño puede ser nombrado secretario de Estado papal, en reemplazo del muy poderoso Angelo Sodano. El argentino quedó bien colocado en la última votación que eligió al papa Ratzinger.

PRINCIPAL |EI país 묘 |Lunes, 19 de septiembre de 2005

Otra nota distintiva del estilo de P12 y P12.COM es una noticia que trató sobre la carta de "advertencia" que el cardenal y secretario de estado vaticano, Angelo Sodano, envió a la Conferencia Episcopal Argentina respecto de un petitorio en relación con el aborto, de la organización no gubernamental Católicas por el Derecho a Decidir:

\section{“ATENTI CON EL DEMONIO”}

PRINCIPAL |Sociedad |

Viernes, 9 de septiembre de 2005

La nota (http://www.pagina12.com.ar/diario/sociedad/3-56236-2005-09-09.html)

explica que:

"El secretario de Estado de la vicaría de Cristo, Angelo Sodano, advirtió sobre la organización Católicas por el Derecho a Decidir. La ONG, cuya voz resonó a favor de la libertad de Romina Tejerina, la chica que mató a su hijo recién nacido producto -según ella- de una violación, impulsa que los religiosos adhieran a un petitorio para que en la declaración política de la Cumbre de Jefes de Estado que se realizará en Nueva York entre el 14 y el 16 de septiembre, se incluya el término "salud reproductiva". La carta en que Sodano advierte sobre la organización "feminista" fue enviada al Episcopado nacional...

Y sigue:

"En ella se indica que "dicha expresión (salud reproductiva) inserta en la mencionada declaración de la Cumbre Milenio+5" fue utilizada "para incluir el aborto como medio de planificación" en las reuniones anteriores de El Cairo y Pekín. "Estén vigilantes -escribió Sodano parafraseando a Jesús-, a fin de que ningún líder religioso católico, sujeto a nuestras jurisdicciones caiga en la trampa firmando ese texto, para que la acción de la Iglesia en defensa de la vida no sea desacreditada."

Otra noticia que planteaba diferencias interesantes en el análisis comparativo de los medios es un artículo firmado por Horacio Verbitsky, donde se postulan relaciones entre 
el pasado del entonces cardenal Bergoglio y el Episcopado católico argentino con la dictadura de 1976-1983 y las estrategias actuales del Vaticano:

\begin{abstract}
SEPULCROS BLANQUEADOS
Bergoglio inició la canonización de los palotinos asesinados en 1976. El cardenal necesita blanquear su historia con vistas a una hipotética sucesión papal. Documentos de las cancillerías argentina y norteamericana y la propia investigación del Episcopado y el Vaticano muestran que el crimen fue obra de la dictadura. Sin embargo, la Iglesia eligió callarlo. Paulo VI se entrevistó con Massera, quien fue recibido con honores en dos universidades jesuitas, cuando Bergoglio era el Superior de la Orden.

PRINCIPAL |EI país 国 |Domingo, 31 de julio de 2005
\end{abstract}

En este tipo de notas el periodista Horacio Verbitsky planteaba y denunciaba la complicidad de Bergoglio con el gobierno de la última dictadura argentina. Varias noticias del período 2001-2010 publicadas en P12 y P12.COM compartieron estos contenidos específicos acerca del vínculo de complicidad entre la violación a los derechos humanos en la Argentina y la complicidad eclesiástica de las autoridades católicas, muchas de esas noticias firmadas por Horacio Verbitsky (entre otras: http://www.pagina12.com.ar/diario/elpais/1-50171-2005-04-24.html, http://www.pagina12.com.ar/diario/principal/diario/index-2005-04-10.html).

Otras notas de análisis y opinión fueron publicadas luego de la elección de Ratzinger como Benedicto XVI:

\title{
SE VA RATZINGER, SURGE BENEDICTO XVI
}

La prensa italiana habla de cuatro documentos de tono "aperturista" que podrían recibir la firma del nuevo Papa. Este empezaría así a abandonar su imagen de intransigente "guardián de la ortodoxia".

PRINCIPAL |EI mundo 国 |Sábado, 23 de abril de 2005

\author{
LA SANTA ALIANZA \\ Por Atilio A. Boron* \\ PRINCIPAL |EI mundo |Jueves, 21 de abril de 2005
}

\section{CÓMO LA SOMBRA DEL PODER LLEGÓ A PAPA}

Detrás de un cónclave que se desarrolló con la velocidad del rayo hubo una larga intriga que empezó en septiembre de 2004, tuvo un centro en la enfermedad del cardenal Carlo María Martini -único rival de peso de Josef Ratzinger-e incluyó un juego de mentiras y presiones y un peculiar sistema electoral para desembocar en el Papa de hoy.

PRINCIPAL IEI mundo 표 |Jueves, 21 de abril de 2005

DE CARA A AMÉRICA LATINA

, Por Washington Uranga

PRINCIPAL |EI mundo |Jueves, 21 de abril de 2005

¿ECUMENISMO? SÍ. ¿DIÁLOGO? SEGURO. 
Después de décadas de predicar la superioridad de la Iglesia Católica en el mundo cristiano y de menospreciar el aporte de otras religiones, Benedicto XVI usó ayer un tono inusualmente conciliador en su primera misa como Papa.

PRINCIPAL |티 mundo 且 |Jueves, 21 de abril de 2005

\section{DOS MIRADAS CRÍTICAS}

PRINCIPAL |EI mundo |subnota

Jueves, 21 de abril de 2005

\section{“JUAN PABLO III", ENEMIGO NÚMERO 1 DE LA MODERNIDAD}

Pese a su participación en el Concilio Vaticano II, la vida religiosa de Josef Ratzinger se orientaría después hacia el rechazo de toda reforma.

PRINCIPAL IEI mundo 표 |Miércoles, 20 de abril de 2005

\section{MUCHOS CONNACIONALES HABIAN SIDO CRITICOS DEL NUEVO PAPA}

\section{ALEMANIA ENTRE LAS DUDAS Y LA CERVEZA}

PRINCIPAL IEI mundo |Miércoles, 20 de abril de 2005

También sobre el cónclave papal P12 Y P12.COM publicaron varias noticias:

\section{SEIS PREGUNTAS Y RESPUESTAS DEL PROCESO QUE SE INICIA TRAS LOS MUROS}

\section{DE UNA LLAVE A HUMO BLANCO Y CAMPANADAS}

PRINCIPAL |EI país 표 |Lunes, 18 de abril de 2005

\section{CÓMO QUIEN ENTRA AL CÓNCLAVE PAPA SUELE EMERGER CARDENAL (O AL REVÉS)}

> Por Washington Uranga

PRINCIPAL |티 país 표 |Lunes, 18 de abril de 2005

\section{ULTIMAS MOVIDAS ANTES DE LA BATALLA}

Coincidiendo con el fin de los nueve días de misas por Juan Pablo II, conservadores y progresistas en el Vaticano se preparan para un intrincado combate por el trono de Pedro, que se inicia mañana.

PRINCIPAL |티 mundo 표 |Domingo, 17 de abril de 2005

\section{QUIÉNES Y CÓMO SON LOS PAPABLES TAPADOS}

Por O. G. Desde Ciudad del Vaticano

PRINCIPAL |EI mundo |Domingo, 17 de abril de 2005

UNA CAMPAÑA ELECTORAL CON PERMISO DEL ESPÍRITU SANTO

El cónclave para elegir nuevo Papa aún no comenzó pero sí lo hicieron las filtraciones y calumnias para tratar de decidir el resultado de la reunión que arranca el próximo lunes.

PRINCIPAL |티 mundo [요 |Sábado, 16 de abril de 2005

\section{LA REFORMA CONTRAATACA EN EL VATICANO}

Después de versiones de que el archiconservador Josef Ratzinger, titular del ex Santo Oficio y ex "príncipe negro" de Juan Pablo II, sería el favorito para sucederlo, tres temas parecen cambiar la tendencia: la economía, la colegialidad y la homosexualidad.

PRINCIPAL IEI mundo 国 |Viernes, 15 de abril de 2005 


\author{
LO QUE UN PAPA PUEDE CAMBIAR \\ Por Juan Arias* \\ PRINCIPAL |EI mundo |Viernes, 15 de abril de 2005
}

\title{
EL "PAPABLE” SOMBRÍO AVANZA
}

En los pasillos vaticanos resuena el nombre del alemán Josef Ratzinger para nuevo Pontífice. A cuatro días del cónclave, el cardenal ultraortodoxo de 78 años y de instintos autoritarios aparece como la carta de la transición, seguido por Carlo María Martini.

PRINCIPAL |EI mundo 国 |Jueves, 14 de abril de 2005

Tras la muerte de Juan Pablo II, varias notas de Página/12 y P12.COM abordaban la información de actualidad sobre la situación en el Vaticano:

\section{VIVIR SIN EL PAPA, O LA CIUDAD SIN REY}

\begin{abstract}
Muchos Iloran, algunos se burlan o protestan, pero toda Roma se prepara para recibir una afluencia sin precedentes de dos millones de personas para los funerales de Juan Pablo II, que encarnó el Pontificado más mediático de la historia. Y las apuestas sobre su sucesor están a toda marcha, mientras los cardenales llegan para su cónclave.

PRINCIPAL |Sociedad |ㅛㅛ |Lunes, 4 de abril de 2005
\end{abstract}

\section{ULTIMO VIAJE DE KAROL WOJTYLA EN MEDIO DEL DOLOR DE SUS FELIGRESES}

"El amor convierte el corazón y da la paz" en un mundo donde "a veces parece olvidado y dominado por el poder del mal, el egoísmo y el miedo", escribió en su mensaje póstumo Juan Pablo II, cuyos funerales comenzaron antenoche.

PRINCIPAL |

CURIOSOS PROTOCOLOS DE UNA SUCESION PAPAL

\section{ESCUDRIÑANDO UNOS TESTÍCULOS}

PRINCIPAL |Sociedad |Lunes, 4 de abril de 2005

JUAN PABLO II SEGUN LOS CATOLICOS PROGRESISTAS

\section{VISTO DESDE OTRA PERSPECTIVA}

PRINCIPAL |Sociedad |표 |Lunes, 4 de abril de 2005

\section{LA IGLESIA QUE EXISTE Y LA IGLESIA QUE SE VIENE}

"No se puede dar respuestas antiguas a preguntas nuevas", ha proclamado el cardenal brasileño Claudio Hummes, arzobispo de San Pablo y uno de los candidatos a la sucesión de Juan Pablo II. Y de eso precisamente se trata la sucesión, en un mundo profundamente cambiado desde que Karol Wojtyla fuera entronizado hace 26 años, con claves en lo político, lo social y la moral sexual.

PRINCIPAL |EI mundo 표 |Lunes, 4 de abril de 2005

En 2004, 2003 y 2002 se repitieron varios tópicos temáticos de otros años: la salud de Juan Pablo II, la designación de cardenales, la posible candidatura papable de Bergoglio, los casos de pedofilia - entre ellos, el caso del arzobispo de Santa Fe, Edgardo Storni. 


\section{LA CEREMONIA DE LOS 30 MÁS UNO DE LOS CARDENALES}

El papa Juan Pablo II nombró ayer a 31 nuevos cardenales. El Pontífice les entregó el capelo rojo cardenalicio a 30 obispos; el trigesimoprimero fue designado "in pectore" (quedará en el anonimato).

PRINCIPAL |EI mundo 표 |Miércoles, 22 de octubre de 2003

ANTE UNA MULTITUD, LA MADRE TERESA QUEDÓ A UN PASO DE SU CANONIZACIÓN

Seis años después de su muerte, la fundadora de las Misioneras de la Caridad y Premio Nobel de la Paz fue beatificada.

PRINCIPAL | Sociedad |ㅛㅛ |Lunes, 20 de octubre de 2003

\section{$\underline{\text { LA SALUD DEL PONTÍFICE }}$}

PRINCIPAL |EI mundo |

Miércoles, 1 de octubre de 2003

JUAN PABLO II PREPARA SU SUCESION

\section{NUEVOS CARDENALES}

PRINCIPAL |Sociedad |Lunes, 29 de septiembre de 2003

EL ESCANDALO DE LA PEDOFILIA EN ESTADOS UNIDOS

\section{VARIAS DÉCADAS DE OCULTAMIENTO}

PRINCIPAL IEl país |subnota |Viernes, 28 de febrero de 2003

UNA REVISTA LO DA COMO PAPABILE

\section{BERGOGLIO NO CREE}

PRINCIPAL |EI país |Miércoles, 4 de diciembre de 2002

\section{UN EXPEDIENTE CONTRA EL ARZOBISPO}

El obispo de Santa Fe fue investigado en 1994 por el Vaticano por abuso sexual de seminaristas. En ese entonces, capeó la tormenta, pero ahora se enfrenta a una investigación judicial.

PRINCIPAL | | Sociedad |표 |Domingo, 18 de agosto de 2002

Página/12 comenzó la digitalización de sus informaciones periodísticas en 2002. De la dimensión de análisis Vaticano, para finalizar este apartado, podemos resaltar algunos rasgos significativos para el análisis de las noticias sobre religión en la Argentina.

En primer lugar, la presencia de las informaciones internacionales sobre el Vaticano demuestra el preponderante espacio textual que ocupa el catolicismo en los tres medios indagados; en segundo lugar, el tratamiento que hace P12 y P12.COM nos muestra cómo, según la perspectiva de este medio, la sede vaticana actúa en sus relaciones con la Iglesia Católica argentina en una relación de interacción asimétrica (al menos en nuestro período de estudio). 
Por último, es significativa también la construcción informativa presente en los tres medios indagados acerca del rol político que adquieren los cardenales en cada país.

\subsection{Asistencia social. Pobreza}

En el período 2001-2010 en la Argentina, las noticias sobre religión que conciernen a la asistencia social y a la pobreza reunieron una diversidad de contenidos temáticos específicos (en el sentido de Segre, 1985) de los que trataremos de señalar sus recurrencias y diferencias en los medios de comunicación indagados.

Las noticias sobre religión trataron sobre la participación pública de la Iglesia Católica en la Mesa del Diálogo -con la sumatoria de otros credos en la ampliación de la Mesa-, las colectas anuales, las procesiones a la Virgen de Luján y a San Cayetano para pedir por pan y trabajo, el manejo de fondos y subsidios estatales, la presencia de manifestaciones religiosas en los barrios populares, hasta el reclamo y la implementación de la Asignación Universal por Hijo en 2009.

Durante 2008 el Episcopado católico argentino había reclamado al gobierno nacional un aumento en la ayuda social. En una operatoria en conjunto con Clarín y CL.COM construyeron la atribución a Benedicto XVI de declaraciones en referencia a la pobreza en nuestro país, como observamos en el capítulo anterior.

Los fenómenos sociales abordados por los medios como acontecimientos para ser convertidos en noticias han hecho que la presencia pública de lo religioso, en relación con la pobreza y la asistencia social, tuviera una amplia y continua visibilidad en el espacio público mediático durante la década de 2001-2010.

Como parte de la visibilidad pública de las relaciones entre las iglesias de distintos credos y el Estado, las informaciones periodísticas de actualidad sobre la asistencia social demuestran las superposiciones entre religión y política.

En estas relaciones entre las iglesias y el Estado es posible observar la presencia de la política en el campo de lo religioso y la presencia de la religión en el campo de lo político -tal como sucedía, de otras formas, en la dimensión de análisis relativa a la educación sexual.

Además ha sido señalado cómo los discursos, las prácticas y las creencias que involucran a la religión y a la política se hallan superpuestos en nuestro país como parte de aquella América Latina en la que no hubo separación laicista entre Iglesia y Estado, a 
diferencia de lo que sucedió en México o en Uruguay (Blancarte, 2008; Esquivel, 2008, 2010).

Estas imbricaciones muestran cuán impregnadas están las creencias religiosas con los modos en que se concibe la organización sociopolítica; en especial, en el andamiaje y funcionamiento de las áreas de políticas públicas para la implementación de la asistencia social del Estado (Carbonelli, 2015; Esquivel y Vaggione, 2015; Mallimaci y Villa, 2007).

En cambio, si se define la asistencia social como un derecho ciudadano que debe garantizar el Estado, entonces la perspectiva de la caridad con que las religiones suelen enfocar la ayuda social se transforma en la necesaria participación estatal para la protección y la consecución de los derechos ciudadanos (Alayon, 1992; Manrique Castro, 1982; Carballeda, 2008, 2006) que, además, prescriben la Constitución Nacional y los tratados internacionales a los que adhiere la Argentina.

Las imbricaciones del asistencialismo y sus relaciones con la política, en particular, han originado una perspectiva peyorativa en el mal llamado clientelismo (Auyero, 2001, 1997; Colabella, 2009, 2010; Vommaro, 2010, 2016; Soprano, 2002, 2005) que, como término despectivo, califica una parte de la ayuda social que se distribuye desde organizaciones, en especial, los partidos políticos, y a partir de los cuales se suele hablar de "favores por votos" (Auyero, 1997) o votos por comida u otras prebendas $^{124}$.

Cuando Javier Auyero (2001) analiza la distribución clientelar de bienes dice que:

El acuerdo más importante que se puede detectar entre quienes tienen una opinión positiva de "sus referentes" es que ellos son vistos como personalmente responsables por la distribución de bienes. La organización que confiere una pensión, ofrece un trabajo, da una medicina o una bolsa de alimentos, no es el Estado nacional, provincial o local sino que son Juancito o Matilde. Ellos son quienes "verdaderamente se preocupan", sienten algo por ellos, son sus amigos y, como buenos amigos, están siempre accesibles y dispuestos a ayudar. ... (Auyero, 2001: 43-44).

\footnotetext{
${ }^{124}$ Entre sus significados originarios, prebenda significa la renta anexa a un oficio eclesiástico (http://dle.rae.es/?id=TuMD5FX). Si bien el recurso etimológico no demuestra nada en sí mismo, es indicativo de que algunas significaciones del término se han desplazado del campo religioso al campo político en sus acepciones contemporáneas.
} 
Ahora bien, en la indeterminación pendular del clientelismo la ayuda distribuida "baja" en muchos casos de las manos de algún político que hace campaña o que, si tiene acceso al aparato de gobierno, la deriva de allí y la hace llegar por los canales informales de la supuesta relación clientelar. Vommaro y Quirós (2011) señalan:

Consideramos que, de la mano de la noción de "habitus clientelar", la preocupación por explorar las dimensiones culturales del clientelismo terminó por instalar — tal vez contrariamente a lo que el propio Auyero pretendía - la imagen de un cliente rehén, ya no de sus patrones o brokers, pero sí del conjunto de disposiciones que producía y reproducía de manera inconsciente - como opera el habitus - en sus relaciones de clientela. Al no dar suficiente peso a la capacidad reflexiva de los actores en las situaciones de intercambio en las que se encuentran involucrados, esta perspectiva perdió de vista la negociación y las controversias a partir de las cuales, cotidianamente, las personas tejen y destejen sus vínculos (Vommaro y Quirós, 2011: 68).

Nos parece que si el habitus es descripto como "conjunto de disposiciones reproducidas de manera inconsciente" entonces en términos psicoanalíticos (Lacan, 1995 [1964]) es difícil poder acceder a su estudio sin tener en cuenta alguna de sus manifestaciones específicas.

También se ha cuestionado en la teoría de Bourdieu (2010) la relativa autonomía de los campos de la religión y la política, en particular, en el contexto social e histórico de América Latina (Algranti, 2010; Cipriani, 2011, entre otros), como parte de esferas diferenciadas que recuerdan la teoría weberiana (Esquivel, 2000).

Vommaro y Quiros (2011) critican el término "puntero" por su uso peyorativo y prefieren hablar de referente en el barrio para aquellos intermediarios en la asistencia social:

En los universos que estudiamos, el término referente barrial es utilizado para denominar a los principales animadores de esas organizaciones territoriales. El referente tiene relación directa y cotidiana con los vecinos, al mismo tiempo que trabaja con o para algún candidato, figura política, línea partidaria o movimiento social, moviliza bases y recluta votantes. (Vommaro y Quiros, 2011: 69).

Sin embargo, en el caso de Caritas no se considera que la ayuda social de organizaciones religiosas sean "prebendas" de los religiosos hacia los pobres (Zapata, 2005). Opera una naturalización en el modo como se presenta en el escenario público de lo social, en cuya construcción narrativa los medios son en gran medida responsables como venimos observando-, acerca de la Iglesia Católica argentina como supuesta participante legítima y desinteresada en el reparto de la asistencia social. 
Los bienes de salvación se mezclan en estos casos con los bienes económicos:

... la asistencia social del Estado, según algunos analistas, adolece de problemas recurrentes y de difícil resolución. Si la ayuda gratuita (alimentos, planes de trabajo, medicamentos, subsidios, créditos, viviendas, etc.) que supone la asistencia social son utilizadas, por parte de sus intermediarios, con fines partidarios o personalistas se dice que eso no es asistencia sino "asistencialismo" o "clientelismo". Es decir, constituyen formas "corruptas" e inmorales de concentrar poder por medio de bienes estatales gratuitos. (Zapata, 2005: 21).

Y también en la concepción de la figura de los voluntarios aparece ese argumento diferenciador de la ayuda social:

Mujeres como Elena y Daniela son reconocidas como voluntarias de Caritas, personas que en esa organización de la Iglesia Católica ejercitan una virtud teologal: la caridad, el amor gratuito, no interesado, brindado al prójimo. "Dar sin esperar nada a cambio" no es una virtud que se desarrolle espontáneamente. La caridad de una voluntaria es una propiedad expresamente cultivada y perfeccionada. Como suelen explicarles los sacerdotes a las voluntarias: si la caridad no es gratuita y desinteresada, si ella busca recompensas en el beneficiado, lo que allí en verdad se generan son "lazos de dependencia" y no la "promoción liberadora de los pobres". Es por eso que el carácter genuino y legítimo de la caridad de la voluntaria es puesto permanentemente en duda y sometido a controles y autoconstricciones estrictas. (Zapata, 2005: 20).

Lo que no se cuestiona es que la Iglesia Católica utiliza hace siglos la caridad como método de evangelización de los necesitados, al menos, en América Latina. En este sentido, la periodista Mariana Carbajal en una nota de P12.com (https://www.pagina12.com.ar/diario/sociedad/3-129768-2009-08-11.html) da lugar al planteo de investigadores de la Universidad de Córdoba sobre la concepción de la pobreza que tiene Cáritas:

\title{
"VEN AL POBRE COMO UN SUJETO PASIVO"
}

\begin{abstract}
Tras la controversia por los planteos del Vaticano y el Episcopado sobre la pobreza, un estudio realizado en la Universidad de Córdoba concluye que Cáritas "opta por darles a los pobres, pero sin permitirles actuar y dependiendo de la solidaridad y la caridad ajena".

PRINCIPAL |Sociedad |표 |Martes, 11 de agosto de 2009
\end{abstract}

Este procedimiento textual que plantea el título y las argumentaciones de los investigadores presentados por la nota, es conocido en la retórica antigua como el recurso de la tesis en vez de la hipótesis (Barthes, 1993: 140-141). Es un procedimiento 
argumentativo en el cual se cuestiona la concepción subyacente (ejemplo: ¿hay que casarse?) antes que la posibilidad hipotética (¿debería X casarse?).

En todo caso la nota de P12.COM reafirma su estilo al establecer este planteo. En cambio en CL y CL.COM tanto como en LN y LN.COM es habitual que se haya objetado en nombre de la libertad y la igualdad religiosa (podríamos decir por la hipótesis antes que por la tesis) que esa ayuda social sea distribuida sólo por la Iglesia Católica y entonces se haya abierto el debate para dar participación a otros cultos, en particular, al evangélico como de hecho sucedió con la creación de ong's que responden a esta religión (Carbonelli, 2015):

\footnotetext{
Lanzaron en Pergamino el plan Solidagro

...Este centro estará administrado por las filiales locales de Caritas, del Consejo de Pastores Evangélicos, del Rotary Club, de los...la viabilidad de la iniciativa Carlos Shaw, coordinador de Caritas local, dijo que con sólo donar lo producido en 40 hectáreas...

18.11.2002 | Información general | Edición impresa
}

Otra de las estrategias institucionales de la Iglesia Católica argentina, cuya visibilidad pública han propiciado los medios, ha sido la alianza interconfesional con las religiones histórico-tradicionales en la organización de las colectas para ayuda social. Por ejemplo, tras la crisis de 2001:

\section{POLÍTICA | TRABAJO CONJUNTO DE CATOLICOS, EVANGELICOS Y JUDIOS \\ Piden tener control de planes sociales \\ 29/08/03 | La Iglesia Católica, los principales cultos evangélicos y la comunidad judía propusieron el control ciudadano de todos los planes sociales como forma de mejorar su eficacia y evitar el clientelismo político. La propuesta contempla mejorar y extender... \\ Una campaña solidaria sin distinción de credos \\ 19/12/01 | En estos días tan especiales, el Grupo Clarín se unió a Cáritas, la Congregación Israelita, la Iglesia Anglicana, el Centro Islámico y Red Solidaria para impulsar la campaña nacional Mi granito de arena. Se trata de una gran iniciativa solidaria...}

En este sentido, la hegemonía institucional del catolicismo en América Latina continúa la herencia colonial y sus modos de organizar el territorio, la fe, la distribución de los recursos y la propiedad privada.

Según el investigador Manrique Castro, el surgimiento del asistencialismo puede explicarse como: 
Lo que define que una determinada tarea sea calificada de asistencialista y otra no, no es la tarea propiamente tal. Una determinada actividad o tarea en un momento de la historia puede tener un cuño profundamente asistencialista de raíz religiosa y caritativa, y la misma mudar de sentido y de perspectiva inserta bajo condiciones sociales, donde el capital ordena las relaciones de producción.

Es dentro de esta perspectiva que tiene que ser vista la relación Iglesia - Trabajo Social, pues los vínculos de la primera con el asistencialismo pre profesional fue mudando de carácter conforme los cambios en la sociedad exigían una redefinición no sólo del asistencialismo católico, sino de la doctrina social de la Iglesia y de sus políticas y relaciones de poder dentro del nuevo cuadro de fuerzas emergente.

Es así como la aparición del Trabajo Social, en cuanto protagonista de una práctica diferenciada de la asistencia pública y de la caridad tradicional, está ligada a los objetivos político-sociales de la iglesia y de las fracciones de clase vinculadas más directamente a ella: Los elementos que más contribuyen al surgimiento del Trabajo Social se originan en la Acción Católica — intelectualidad laica, estrictamente ligada a la jerarquía católica - que propugna con espíritu mesiánico la recristianización de la sociedad mediante un proyecto de reforma social. Estos núcleos de legos orientados por una prédica política de cuño humanista y antiliberal, se lanzan a una vigorosa acción dirigida a penetrar dentro de todas las áreas e instituciones sociales, creando mecanismos de intervención en amplios sectores de la sociedad con la estrategia de ir progresivamente logrando puestos de importancia en el aparato del Estado. (Manrique Castro, 1982: 3).

En términos históricos y generales podemos decir que, a la promesa de redención en un 'más allá', las religiones universales como el judaísmo, el islamismo y el cristianismo basadas en El Corán o en la Biblia y denominadas de salvación-, suman la obligación de ayudar al prójimo: no hay salvación personal sin la participación en la vida comunitaria.

Si bien en todas las épocas hubo algún tipo de ayuda a los más necesitados por parte de distintas organizaciones sociales, según el teórico Ezequiel Ander-Egg (1985), puede tomarse a Vicente de Paul como uno de los referentes iniciadores de la asistencia social católica.

Para Manuel Manrique Castro, la Iglesia Católica planteaba un camino en términos de organización social:

En el terreno específico de lo que se denominaba asistencia social, organizó formas de tratamiento a los problemas de la época, previa a la explosión industrial.

La Iglesia, por otro lado, se movía dentro de un proyecto más general de reforma social, cuyo contenido principal era luchar en pro de la recuperación de la hegemonía cristiana, cuando ésta empezó a peligrar en virtud tanto de la influencia marxista, como la propuesta liberal. La lucha contra la secularización y la racionalidad que acompaña la expansión del capitalismo, asumió el carácter de utopía social, cuya inspiración procedía del pasado de la hegemonía ideológica de la Iglesia sobre la sociedad y el Estado, y residía en la búsqueda de la restauración de aquel dominio perdido.

Como parte de la estrategia destinada a la recuperación de su hegemonía ideológica, tanto la jerarquía católica como los legos valoraron en mayor medida la acción social, así como la participación activa y organizada del laicado en la vida social, 
creándose para ello los soportes de tipo legal e institucional que le dieran viabilidad. Dentro de estos canales se destacan la enseñanza católica, los centros de estudios, la acción católica, las universidades, los sindicatos católicos, nuevas formas de acción de las parroquias, etc. Esta respuesta de la Iglesia obedecía a los cambios operados en el seno de las sociedades latinoamericanas, en las que la acción de la Iglesia Católica y su labor a través de sus agentes, perdía significativo espacio. (Manrique Castro, 1982: 6).

Según este autor, la Iglesia Católica diferenciaba su visión de mundo respecto al liberalismo y al socialismo en términos de organización social, y trataba de recuperar una hegemonía humanista perdida:

En el período de tránsito del Trabajo Social hacia su profesionalización, cuando accede para ello a los centros superiores de enseñanza, y se vincula a ciertas instancias del Estado, o ingresa directamente a la universidad, dos encíclicas papales jugaron un papel sumamente importante para perfilar su desarrollo, aunque junto a ellas fue la acción directa de la Iglesia y su invariante inspiración ideológica lo que dio figura y fondo doctrinario a la formación de los primeros centros de formación superior. Nos referimos a la Encíclica Rerum Novarum aprobada por el Papa León trece el 15 de mayo de 1891 y la Encíclica Cuadragésimo Anno del Papa Pío once, aprobada dos años después del gran crack capitalista de 1929, el 15 de mayo de 1931. (...)

El derecho a la propiedad según la Encíclica es un derecho natural que procede de la generosidad divina, pues al haber dado Dios la tierra a todo el linaje humano - así se dice-, lo hizo para que use de ella y la disfrute sin que esto se oponga, en grado alguno, a la existencia humana.

Además, continúa el razonamiento de la Encíclica, "Cuando Dios dio la tierra en común a todo el linaje humano, no significa que todos los hombres indistintamente sean señores de toda ella, sino que no señaló Dios a ninguno en particular la parte que había de poseer, dejando a la industria de los individuos y de las leyes de los pueblos la determinación de lo que cada uno en particular había de poseer".

El poderoso recurso de la religión y de la Iglesia Católica fue esgrimido descarnadamente para justificar -a través de la incuestionable voluntad divina- la injusticia reinante en la tierra. Dios había dado la tierra a todos, pero, y enfatizado por la propia Encíclica, no lo hizo equitativamente; la industria de los hombres y sus leyes eran las que regían en supuesta condición de igualdad en el reparto del mundo. (Manrique Castro, 1982: 6-8).

La concepción católica respecto a la propiedad privada y a los poderes instituidos conecta en gran medida con la institucionalidad vaticana. Desde esta perspectiva la Reforma Luterana, en cambio, habría individualizado el ideal ascético monástico y lo habría secularizado en la prosperidad individualista como signo de la gracia, según señala otro autor, Anthony Giddens, en su comentario sobre la obra de Max Weber:

... el protestantismo rompió con el ideal monástico del catolicismo. Sin embargo, el protestantismo ascético es, en parte, la simple culminación de tendencias largamente arraigadas en la historia global del cristianismo. El ascetismo católico ya tenía un carácter racional, y hay una línea directa de desarrollo desde la vida monástica a los 
ideales del puritanismo. El principal efecto de la Reforma, y de la posterior historia de las sectas protestantes fue trasladar esto desde el monasterio al mundo ordinario. (Giddens, 1994: 222).

El rol de la asistencia social en otras religiones, por ejemplo, en el judaísmo y el islamismo se encuentra ligado a la identidad cultural y étnica, al sentido de pertenencia a un grupo de la colectividad y a sus lazos solidarios (Setton, 2008, estudia el desarrollo del grupo Jabad Lubavitch en la Argentina).

En los cultos protestantes históricos, la prosperidad y la moderna idea de profesión-vocación aparece como signo de aceptación divina. En el islamismo, la obligación de ayudar forma parte de las Suras del Corán; la limosna obligatoria (zakat) y la caridad voluntaria (sadagat) son parte de las fiestas de Ramadán y del sacrificio como obediencia a cumplir ${ }^{125}$. Sin embargo, las noticias sobre la asistencia social en relación con otras religiones que no sean cristianas suelen ser escasas en los medios seleccionados.

El diálogo interreligioso y las situaciones límite como momentos de crisis o catástrofes aportan, a veces, algún tipo de noticia sobre la presencia pública de organizaciones como la Delegación de Asociaciones Israelitas Argentinas (DAIA) en conjunto con la Asociación Mutual Israelita Argentina (AMIA), o de CIRA (Centro Islámico de la República Argentina) pese a que el trabajo social de estas entidades se desarrolla durante todo el año.

Algunos de los sectores o líderes religiosos como Abraham Skorka y Omar Abud en varias ocasiones se reunieron con Jorge Bergoglio, en Buenos Aires, y luego se hizo famosa la foto del abrazo entre los tres como símbolo del diálogo interreligioso y la convivencia de las religiones.

En P12 y P12.COM es habitual encontrar columnas de opinión y artículos del rabino Daniel Goldman; en cambio de Abraham Skorka, en CL y CL.COM. De todas formas, la ayuda social que no está relacionada con la institucionalidad católica y estatal, no suele ser noticiable en la información periodística de actualidad. Ni siquiera el trabajo del Ejército de Salvación aparece de modo comparativo con las noticias sobre Caritas.

Tampoco suelen aparecer con frecuencia noticias acerca del trabajo barrial de los evangélicos (Carbonelli, 2015), ni relacionadas con la prevención por el consumo de

\footnotetext{
${ }^{125}$ Agradezco a Agostina Zaros las referencias para esta cuestión.
} 
drogas y el delito, o con la amplia experiencia de los pabellones evangélicos en las cárceles del país (Algranti, 2010).

\subsubsection{Las noticias sobre Caritas}

El comienzo de Caritas como institución de ayuda social en nuestro país tiene un llamativo componente político. Surge luego de acontecido el derrocamiento del segundo gobierno de Juan Domingo Perón, en 1955.

Evita y la Fundación que dirigía, tuvieron un protagonismo fundamental en el pasaje del sistema de las sociedades de beneficencia, fundado por las "damas de beneficencia" como parte de la herencia colonial-católica, al sistema de asistencia social estatal (Zapata, 2005).

El Estado, llamado de "bienestar" -a semejanza del Welfare State y los planes de F. Roosevelt y J.M. Keynes en USA, pero también del Plan Marshall que ayudó en la reconstrucción de la Europa de posguerra-, comenzaron por reconocer la protección de los derechos de los necesitados, de los "desamparados".

El Estado peronista identificaba en las madres solteras o abandonadas, en los niños y ancianos pobres, en los discapacitados, a los sectores vulnerables cuyos derechos sociales debían ser protegidos en busca de la "armonía de clases" y la justicia social, después de las dos guerras mundiales en las que habían confrontado los fascismos, las democracias y los socialismos como sistemas de gobierno antagónicos:

Caritas surgió a nivel internacional en 1950, en pleno contexto de posguerra y descolonzación (en los continentes africano y asiático). Paralelamente a la emergencia de organismos multilaterales -como el Fondo Monetario Internacional, el Banco Mundial, las Naciones Unidas- el Vaticano creó "Caritas Internationalis". Con ello incorporaba sus prácticas "caritativas" o "solidarias" en la nueva configuración internacional. En la Argentina, su homónima nacional fue creada en 1956 por la Conferencia Episcopal Argentina, un año después del derrocamiento del gobierno constitucional de Juan D. Perón. Desde entonces se extendió por todo el territorio nacional por medio de parroquias y capillas. Fue el gobierno peronista el que estatizó, en 1947, a la centenaria y poderosa Sociedad de Beneficencia. Basada en los ideales cristianos de la caridad, esta Sociedad se ocupó de los pobres argentinos por más de un siglo. En abierta oposición a la "irregular y puntual" beneficencia, el peronismo colaboró en la consolidación del "Estado de Bienestar", institucionalizó y profesionalizó un modelo de "ayuda" estatal dirigida a los pobres, basado en la gratuidad: la asistencia social. (Zapata, 2005: 21). 
En el período que indagamos, 2001-2010, el principal evento con el que se relacionan las noticias relativas a Caritas es la colecta anual "Más por menos" que lleva adelante la Iglesia Católica argentina todos los años.

Además, fueron frecuentes las noticias que trataban sobre eventuales acciones solidarias, organizadas por la Pastoral Social católica ante distintas catástrofes y emergencias que sucedieron entre 2001-2010, dirigida en este período por el obispo de San Isidro, Jorge Casaretto.

Es interesante observar cómo intervinieron otros cultos en conjunción con la Iglesia Católica ${ }^{126}$, y cómo las declaraciones sobre la pobreza muchas veces fueron un preludio -y un llamado de atención, a las colectas y acciones sociales de Caritas y sus convocatorias a la sociedad por donaciones de dinero, ropa y materiales de construcción, entre otros.

La desnutrición infantil en provincias del interior del país, la crisis argentina de 2001 y las situaciones de emergencia en otros países han sido los motivos centrales de los pedidos de colaboración, muchas veces en conjunto con el Estado y otros cultos, u organismos nacionales e internacionales.

Con el obispo Jorge Casaretto como presidente de la Pastoral Social, Caritas fue una de las líneas de acción más activas dentro del catolicismo (Zapata, 2005) con su visibilidad en los medios de comunicación.

Página/12 y P12.COM tenían un particular énfasis en las noticias que involucraban la figura religiosa de Casaretto, a quien consideraba en el sector "progresista" de la Iglesia Católica ${ }^{127}$.

La Nación y LN.COM también otorgaba un espacio destacado a Casaretto entre sus noticias -aunque por motivos distintos a los de pagina12.com, ya no por el supuesto progresismo sino por su vinculación territorial con el tradicional municipio de San Isidro.

En Clarín y CL.COM, en cambio, fue frecuente la recurrencia del nombre de Jorge Bergoglio en sus noticias. Cuando se trataba de informaciones sobre acción social católica predominó entre sus títulos el nombre de Caritas, más que el de Casaretto.

\footnotetext{
${ }^{126}$ La interreligiosidad o interconfesionalidad, es decir el vínculo entre los distintos cultos, fue una estrategia implementada ya en el papado de Juan XXIII y continuada en el de Juan Pablo II, que Bergoglio se encargó de poner en práctica en la Argentina cuando era cardenal: (http://edant.clarin.com/suplementos/especiales/2004/03/03/1-00415.htm).

${ }^{127}$ Según nos dijo el periodista de P12 Washington Uranga, entrevistado para esta tesis, por motivos de accesibilidad informativa a la palabra de Casaretto.
} 
La Asignación Universal por Hijo (AUH) y su implementación fue tema de debate político legislativo y en los medios de comunicación, entre 2009 y 2010:

\title{
POLITICA | BUSCAN DEBATIR EL TEMA EN EL CONGRESO \\ Críticas de la Iglesia, el CELS, la oposición y el Defensor
}

10/09/10 | La Iglesia, la Defensoría del Pueblo, el CELS y dirigentes de la oposición criticaron la suspensión de la Asignación Universal por hijo a 300.000 chicos. Cáritas Argentina y el Consejo Superior de Educación Católica (Consudec) advirtieron que la...

\section{GOBIERNO | SU VISION SOBRE LA SITUACION SOCIAL}

\section{Para la Iglesia, la asistencia por hijo no es suficiente} 12/06/10 | Para la Iglesia, la asignación universal por hijo de \$180 mensuales "no resuelve la pobreza estructural", si bien constituye "un alivio importante". Más aún: considera que "la suba de precios acrecienta" el número de pobres. Y cree, en fin, que la..

\section{ECONOMÍA | SUBSIDIOS}

\section{Asignación por hijo: acuerdo con la Iglesia}

21/04/10 | El Gobierno se encamina a reconocer la constancia de escolaridad de los colegios privados y a seguirles pagando así la asignación por hijo a los padres de casi 300 mil chicos que habían visto peligrar la continuidad del beneficio....

Algunos ejemplos de lanacion.com:

\author{
Para Cáritas, se trata de un "avance extraordinario" \\ El director de Caritas, Gabriel Castelli, consideró hoy que el anuncio de la asignación mensual de 180 \\ pesos por hijo para desocupados y trabajadores... \\ 30.10.2009 | 11:23 | Política | lanacion.com
}

Para la oposición, se mantiene el clientelismo

La oposición criticó con dureza el decreto presidencial que instaura una asignación de 180 pesos para hijos de desempleados y trabajadores informales. Advirtió que no es universal y que, por ello, mantendrá las prácticas clientelares y, además, cuestionó que se financie con el dinero de los

30.10.2009 | Política $\mid \underline{\text { Edición impresa }}$

En pagina12.com:

\section{PARA CÁRITAS SIGNIFICA UN AVANCE HACIA "UN SISTEMA SOCIAL MÁS JUSTO" PERO RECLAMÓ UN DEBATE PARLAMENTARIO}

La Comisión Nacional de Justicia y Paz y Cáritas expresaron su satisfacción por la extensión de la asignación por hijo a los trabajadores informales y a los desocupados.

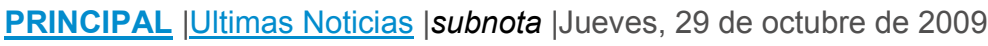

\section{LA IGLESIA QUIERE UN INGRESO BIEN}

La iniciativa eclesiástica propone crear un fondo Básico para la Igualdad y la Equidad de la Niñez (BIEN), que requeriría 12.900 millones de pesos. Propone reasignar fondos del Plan Familias y el Jefas y Jefes y obtener una partida extra equivalente al 0,9 por ciento del PBI.

PRINCIPAL IEI país 国 |Miércoles, 21 de octubre de 2009 


\section{"NI UN EXCLUIDO EN LA MESA DE LA VIDA" \\ , Por Washington Uranga \\ PRINCIPAL |Sociedad |Sábado, 10 de octubre de 2009}

La discusión entre el gobierno kirchnerista y la Iglesia Católica argentina por las cifras de pobreza en el país también estuvo presente en CL.COM a partir de una serie de notas sobre el supuesto crecimiento de la pobreza:

\section{POLITICA | LA POLEMICA POR LA SITUACION SOCIAL \\ El Gobierno volvió a cruzar a la Iglesia por el índice de pobreza \\ 19/08/09 | Un nuevo capítulo de una larga cadena de cruces se escribió ayer entre el Gobierno y la Iglesia Católica. Y, otra vez, el tema fue la pobreza. El Gobierno tomó distancia del número que difundió la cúpula del Episcopado (habló de un $40 \%$ de pobres) y... \\ POLÍTICA | REUNION DE LA CUPULA DEL EPISCOPADO}

\section{La pobreza ya ronda el $40 \%$, insiste la Iglesia}

18/08/09 | La Iglesia sigue firme en su propósito de convertir al combate contra la pobreza en un tema central del Gobierno, la oposición y de todos los sectores de cara a la celebración del Bicentenario de la Argentina.En la primera jornada de la reunión de...

POLÍTICA | ENCUENTRO EN LA GOBERNACION BONAERENSE

\section{Scioli les pidió ayuda a los obispos para luchar contra la exclusión social}

14/08/09 | Daniel Scioli pidió a los obispos de la provincia de Buenos Aires "un profundo apoyo como pastores de la Iglesia para trabajar juntos contra la exclusión social".A resguardo del sarpullido político que provocó en el Gobierno Nacional la declaración...

\section{Hay más familias que piden ayuda y los comedores comunitarios no dan abasto}

$\mathbf{1 1 / 0 8 / 0 9}$ | Distintas organizaciones sociales y religiosas se reunieron para fortalecer la lucha contra el hambre en el país. La realidad -sostienen los referentes sociales- es que los comedores comunitarios están otra vez repletos de familias que van a buscar...

En lanacion.com:

\footnotetext{
Casaretto: "La percepción es que está aumentando la pobreza"

En medio de la polémica por la fidelidad de los índices que ofrece el Indec, el encargado de Pastoral Social de la Iglesia Católica, monseñor Jorge Casaretto, consideró que puede percibir que la pobreza "está aumentando". Hace una semana, el Gobierno había dado a conocer que según el organismo 20.05.2008 | 11:41 | Política | $\underline{\text { lanacion.com }}$

"La mejoría convive con la pobreza"

...pasado se recaudaron casi \$ 6.723.000. Por teléfono, Caritas Argentina recibe colaboraciones por el 0810-222-74827. Por Internet, se puede donar a través de la página web www.caritas.org.ar . También se pueden hacer depósitos en cheque o...
}

09.06.2007 | Cultura $\mid \underline{\text { Edición impresa }}$ 


\begin{abstract}
$\underline{\text { La Iglesia reclama no olvidar la pobreza }}$
"No podemos ni debemos olvidar que la realidad de pobreza y exclusión nos sigue interpelando de manera muy fuerte a todos", aconsejó el presidente de Cáritas, monseñor Fernando Bargalló, al presentar un informe en la 92a. Asamblea Plenaria del Episcopado, que concluirá mañana en Pilar. Ante el

10.11.2006 $|\underline{\text { Cultura }}| \underline{\text { Edición impresa }}$
\end{abstract}

El obispo Jorge Casaretto tuvo un rol protagónico en 2008 y 2009. Sobre el tema de la pobreza, ligado al clientelismo, se publicaron varias noticias en pagina12.com:

\title{
"NO PUEDE HABER NINGUNA DISCUSIÓN QUE PONGA EN LA SOMBRA LA LUCHA CONTRA LA POBREZA"
}

\begin{abstract}
El titular de la Comisión Episcopal de Pastoral Social, obispo Jorge Casaretto, advirtió a la dirigencia política que ninguna ley, por importante que sea, puede estar por encima de la discusión para luchar contra "el gran problema" de la pobreza y la exclusión social en el país, que volvió a juzgar "escandalosa".

PRINCIPAL |Ultimas Noticias |표 |Sábado, 19 de septiembre de 2009
\end{abstract}

\section{"EL TEMA NO SON LAS CIFRAS"}

\begin{abstract}
El vocero del Episcopado, Jorge Oesterheld, dijo que "el tema no es discutir cifras, sino preocuparse por hacer algo". Después de tres días de debate, los obispos formaron una comisión para elaborar un proyecto de asignación universal por hijo.

PRINCIPAL |티 país 国 |Viernes, 21 de agosto de 2009
\end{abstract}

En 2009 el papa Benedicto XVI hizo declaraciones en general sobre la pobreza en América Latina y los miembros de la Episcopado Católico argentino las retomaron para relacionarlas con las cifras de pobreza en el país, tal como publicó CL.COM y vimos en el capítulo sobre Vaticano:

POLITICA | EL EX PRESIDENTE HABLO EN UN ACTO EN QUILMES Y DEFENDIO LAS RETENCIONES A LA SOJA

\section{Kirchner admitió que la pobreza es más alta que la que dice el INDEC}

06/08/09 | Poco más de un mes de abstinencia fue suficiente. Néstor Kirchner volvió ayer a pisar el Gran Buenos Aires, hablar detrás de un atril y enfrentar las cámaras con definiciones fuertes en todos los temas. El ex presidente desembarcó en un encuentro...

POLÍTICA | DESPUES DE QUE EL TITULAR DE LA PASTORAL SOCIAL ANTICIPO A CLARIN QUE RONDA EL 40 POR CIENTO

\section{El Papa pidió reducir en el país el "escándalo de la pobreza"}

06/08/09 | La campaña de la Iglesia para instalar como tema prioritario tras las elecciones el combate a la pobreza recibió ayer un fuerte impulso que sacudió el tablero político. Nada menos que el Papa Benedicto XVI -aprovechando su habitual mensaje con... 
La colecta de Caritas, las declaraciones del presidente de esta organización y un editorial publicado por CL Y CL.COM fueron noticias relevantes en 2009:

\section{SOCIEDAD | CAMPAÑA NACIONAL \\ Se realizó la tradicional colecta anual de Cáritas}

14/06/09 | Bajo el lema "Es posible. Tu solidaridad transforma. Compartir nos hace bien", se llevó a cabo durante el fin de semana la Colecta Anual de Cáritas. Este año, la entidad distribuyó en las 3.500 parroquias, capillas y centros misionales del país, pero..

POLÍTICA | PLANTEO DEL PRESIDENTE DE CARITAS, OBISPO FERNANDO BARGALLO

\section{La Iglesia reclama a los candidatos que digan cómo repartir la riqueza \\ 08/06/09 | En el tramo final de la campaña, la Iglesia salió a reclamarle con fuerza a los} candidatos que proponen la distribución de la riqueza, que expliquen cómo creen que debe hacerse. "Sería bueno que todos los que proclaman pomposamente que se van a...

OPINIÓN | EDITORIAL

\section{El desafío de promover la inclusión social}

14/02/09 | Las consecuencias de la crisis económica internacional que han comenzado a manifestarse en el país se reflejan en dimensiones, indicios e indicadores de diferente tipo, todos de relevancia, merecedores de atención y necesitados de respuestas...

En 2004 se discutió el "clientelismo" y los planes sociales en una serie de notas consecutivas publicadas por CL y CL.COM. A fines de 2003, Casaretto fue entrevistado por el tema del "clientelismo" como titular de Cáritas.

\section{ZONA | UN TERCIO SE DISTRIBUYE EN LA PROVINCIA DE BUENOS AIRES}

\section{Casi el $20 \%$ de los hogares vive de planes para pobres}

03/01/04 | No es sólo una cuestión de piqueteros: en la Argentina, casi dos de cada diez familias reciben un Plan Jefas y Jefes de Hogar y están pendientes de una discusión política que se saldará este año: ¿qué va a pasar con los planes sociales? Los planes...

En el texto, la nota señalaba la relación "clientelar":

El mecanismo de control fue ideado por la Mesa del Diálogo Social, integrada por organizaciones sociales y empresariales, que le planteó a Duhalde que los fondos deberían ser administrados por las comunas y controlados por las ONG, evitando pasar por las provincias, a las que calificaron de "corruptas". Sin embargo, en muchos distritos directamente no se creó el Consejo Consultivo, al tiempo que en otros los Consejos fueron sobrepasados por la velocidad de punteros y funcionarios municipales. En la mayoría de los distritos el intendente se quedó con el "poder" máximo respecto a los planes: es quien ordena las bajas. Esto quiere decir que puede quitarle el plan a un beneficiario si un puntero político suyo le indica que no aporta su "peaje" o no concurre a los actos políticos. "No sólo los piqueteros usan a los beneficiarios para los actos, los intendentes también. $Y$ el año pasado los planes fueron uno de los motores del PJ en todas las elecciones provinciales", explicó un líder de una ONG. A nivel nacional sucede lo mismo. Existe un Consejo Nacional de Administración, Ejecución y Control, presidido por el ministro de Trabajo e 
integrado por la CGT, la CTA, Cáritas, AMIA, Consejo Evangélico, Foro Social, Asociación Bancos Argentinos, Sociedad Rural y la UIA. El resultado de estar en esa mesa fue que muchas de esas organizaciones obtuvieron planes para sus proyectos. Pero el control y la decisión de políticas fueron escasos. "Los pasan como alambre caído", fue la expresión del líder piquetero Juan Carlos Alderete. Es cierto: según un estudio de las propias ONG, al que accedió el Equipo de Investigación, "es escaso el control social de los planes", por falta de personal, normas "confusas y cambiantes" y "poca claridad en los reportes". De acuerdo a este trabajo - firmado por Cáritas, la AMIA, el Grupo Sophia, el Foro del Sector Social y el Consejo Evangélico-, "no se les informa a los consejos sobre las altas y las bajas de los beneficiarios y no se les entrega informes, manuales de procedimiento ni capacitación que les permita conocer sus roles y atribuciones".

En la sección Zona, CL y CL.COM ampliaban la información cuya fuente era el Centro de Estudios Legales y Sociales (CELS):

ZONA

\title{
Informes
}

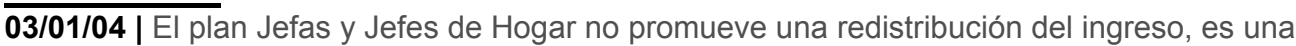
política asistencial focalizada. No es universal y no alcanza los requisitos mínimos para superar el umbral de la indigencia. Informe del CELS (mayo 2003) Hay...

\section{POLITICA | DESPUES DE LAS CRITICAS DEL GOBIERNO AL "MANEJO CLIENTELISTICO" EN LA PROVINCIA}

\section{Planes sociales: se encendió una mecha en el conurbano}

26/12/03 | El ministro del Interior, Aníbal Fernández, admitió que "hubo intendentes que hicieron las cosas mal" en el manejo de los planes sociales y encendió una mecha en el conurbano bonaerense. Fernández habló con una radio de la Capital el jueves y aceptó...

En lanacion.com:

Critican el plan Jefes y Jefas de Hogar

\begin{abstract}
...deben ser mejorados. Esa es la idea que Caritas Argentina intenta transmitir al Gobierno...rechazó el pedido minutos después. "Caritas plantea abrir el plan Jefes. Nosotros hoy...Según datos que manejan fuentes cercanas a Caritas, existen en la Argentina entre 200...
\end{abstract}

17.06.2005 | Economía $\mid \underline{\text { Edición impresa }}$

"Caritas es un freno al clientelismo"

...afirma el obispo, que desde 1999 preside Caritas Argentina. La institución lleva adelante...Queremos que el plan Remediar lo controle Caritas. Se trata de un plan que distribuye botiquines...estábamos en condiciones. Y nos dijo que si Caritas no entraba, el BID no acordaba el crédito...

24.12.2004 $|\underline{\text { Cultura }}| \underline{\text { Edición impresa }}$

"Fomenta una cultura de la vagancia"

El presidente de Caritas Argentina y obispo de San Isidro, monseñor Jorge Casaretto, aconsejó...educativa." Fomentar el trabajo Por su parte, el director nacional de Caritas, Eduardo Serantes, planteó ayer la necesidad de que "la educación...

20.11.2003 $|\underline{\text { Política } \mid}| \underline{\text { Edición impresa }}$ 


\begin{abstract}
Casaretto volvió a criticar la utilización política de los planes sociales
El presidente de Cáritas Argentina, monseñor Jorge Casaretto (San Isidro), insistió hoy en señalar que "los planes sociales sin contraprestación" fomentan "la vagancia", y ratificó que "en muchas provincias, en muchos lugares todavía hay utilización política de los planes". "Todavía hay una

24.12.2003 | 10:23 | Información general | lanacion.com
\end{abstract}

En esta entrevista con CL.COM, Jorge Casaretto "denunciaba" como presidente de Cáritas el manejo "político" de los planes sociales, luego de que 2002 fuera "el año" de la crisis, que había comenzado a fines de 2001:

POLITICA | REPORTAJE AL TITULAR DE LA ORGANIZACION CATOLICA CARITAS

\title{
Casaretto: "Hay muchos lugares donde sigue el manejo político de los planes"
}

25/12/03 | La Iglesia no está conforme con el modo en que se están implementando los planes de Jefas y Jefes desocupados y cree que — pasado el peor momento de la crisis — es tiempo de hacerle las correcciones. A casi dos años de que los obispos alentaran su...

SOCIEDAD | DONACIONES DE CIUDADANOS ESTADOUNIDENSES QUE PERMANECIERON VARIAS SEMANAS EN LA ADUANA

\section{Tucumán espera la mercadería de un polémico contenedor}

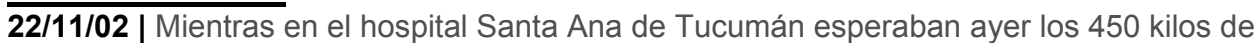
comida, ropa, medicamentos y juguetes enviados por ciudadanos estadounidenses, la polémica en torno del estado de las donaciones no se detuvo. De todas maneras, y para...

SOCIEDAD | SOLO CARITAS ATIENDE A 600.000 PERSONAS EN TODO EL PAIS

\section{Los comedores solidarios están desbordados}

20/11/02 | Es la una y el viejo galpón del ferrocarril huele a guiso. A las voluntarias de "Ayúdame a crecer" se les nota el cansancio en la cara. No es para menos: es el tercer turno del almuerzo en ese rincón de la villa 21-24 de Barracas. Allí comen 450...

\section{Historias de hambre, padecimientos y dolor en seis} provincias

19/11/02 | Dos gemelos de tres años con desnutrición avanzada en Córdoba Dos hermanitos gemelos de 3 años están internados desde el jueves en el hospital de Alta Gracia, 45 kilómetros al oeste de la capital cordobesa. Padecen desnutrición "grave y...

Además de la figura de Jorge Casaretto, CL.COM publicaba noticias sobre, la elección del gobierno de la Alianza de Juan Pablo Cafiero como ministro de Desarrollo Social al intentar incorporar algunos peronistas en su gobierno antes de la crisis de fines de 2001:

\section{Hoy la Patria requiere algo inédito}

13/05/01 | 1. Muchas veces en nuestra historia tuvimos que asumir situaciones difíciles. Los cristianos sabemos que Jesús es el Señor de la historia y que la fuerza de su Resurrección es siempre fuente de esperanza, sobre todo cuando las dificultades son... 


\title{
Cafiero busca sumar a la Iglesia en las tareas de ayuda social de su gestión
}

02/05/01 | En el debut como ministro de Desarrollo Social, Juan Pablo Cafiero dio ayer un paso adelante para sumar a la Iglesia a su propuesta de impulsar un Pacto por los Niños. Cafiero recibió una clara señal favorable a la iniciativa de parte del titular de...

Como vemos, en las noticias sobre religión que publicó CL.COM en la década 20012010 fue predominante la presencia pública de la Iglesia Católica: incluso aunque la temática religiosa no fuera el eje central de la noticia, si aparecía alguna figura o referencia religiosa era católica.

Las coincidencias entre los contenidos específicos de las noticias de LN y LN.COM respecto a las de CL y CL.COM fueron frecuentes:

\author{
Estaba en buen estado el $86 \%$ del contenedor \\ Personal de Caritas clasifica y embala las donaciones norteamericanas, que ya partieron para Tucumán \\ 05.12.2002 | La Nación \\ $\underline{\text { Aumenta la asistencia espiritual y social de los centros religiosos }}$ \\ Una niña disfruta del almuerzo en un centro de Caritas, en Belgrano \\ 27.01.2002 | La Nación \\ $\underline{\text { Duhalde convocará a un diálogo amplio, avalado por la Iglesia }}$ \\ Staffolani, Angulo Barturen, Pampuro, Caterbetti, Maccarone y Casaretto, ayer, en la sede de Caritas \\ 11.01.2002| $\underline{\text { La Nación }}$ \\ El gobierno porteño no ahorra en comida \\ Caritas alimenta a 250.000 personas por día; el Gobierno de la Ciudad paga 70.000 almuerzos; la \\ diferencia en el costo de las raciones es notable \\ 10.12.2001 | $\underline{\text { La Nación }}$ \\ "Al país hay que darle, no pedirle" \\ ...Jorge Casaretto es la cara visible de Caritas Nacional, organización no gubernamental...acciones de \\ asistencia y promoción humana, Caritas atiende las necesidades de un millón de...crecido", dice monseñor \\ Casaretto. Caritascuenta, además, con otras fuentes... \\ 29.07.2001 | Enfoques $\mid \underline{\text { Edición impresa }}$
}

CL.COM ha marcado la agenda mediática como diario de referencia dominante (Albornoz, 2006) tanto en su edición impresa como en la edición digital a nivel nacional, a la cual solía plegarse y complementar LN.COM desde un periodismo interpretativo con la firma de periodistas especializados y columnistas. 
En cambio, Página/12 y P12.COM han tendido a diferenciarse de ambos medios no sólo en cuanto a su política editorial, también en su diseño multimedia y en la elección de la plataforma de código abierto creada con el software libre Linux para el sitio web de su portal de noticias www.pagina12.com.ar.

En lo que se diferencian Clarín y La Nación, tanto en sus ediciones impresas como digitales, es en la respectiva presentación estilística de las noticias, como ya hemos resaltado en varias oportunidades. CL y CL.COM privilegian la urgencia y espectacularidad de los titulares mientras que LN y LN.COM tienen una manera de presentar las noticias ligadas al estilo de la prensa blanca o "seria", cuyo principal rasgo sería la mesura y la interpretación reflexiva de los acontecimientos. 


\section{CONCLUSIONES}

Todavía hoy, las construcciones enunciativas que la sociedad reconoce como informaciones de actualidad periodística sobre fenómenos de religiosidad constituyen uno de los insumos regulares de los periódicos impresos y digitales.

Los acontecimientos sobre religión, en cambio, implican diferentes reconstrucciones sociales $^{128}$. Las noticias sobre religión son una de esas reconstrucciones entre las que realiza la sociedad, y de las que se encarga en sus condiciones productivas e institucionales el sistema de los medios de comunicación (Luhmann, 2000) de un país o una región.

En este sentido las referencias, jerarquizaciones, enfoques y retomas -entre otras operatorias- del discurso de los medios en la elaboración de lo que llamamos actualidad (Verón, 1987) es un fenómeno y proceso social que tratamos de describir con el término mediatización (Verón, 2013, 1997, 2001b; Hjarvard, 2016).

De esta manera la construcción de representaciones desde los medios y las estrategias de las instituciones, tanto de las religiosas como de las mediáticas, forman parte de ese entramado de semiosis que llamamos espacio público mediático (Ferry, Wolton y otros, 1998; Muraro, 2000).

En el caso de los fenómenos relativos a la religiosidad, luego de los cuestionamientos a las teorías de la secularización (Hervieu-Léger, 1996, 2005; Casanova, 1994; Cipriani, 2011; Mallimaci, 1993, 1996, 2015; Ameigeiras, 2008; Esquivel, 2008), podemos decir que uno de los resultados de este trabajo investigativo ha sido constatar que también en los espacios de los medios sobrevive con vitalidad el discurso religioso y que presenta una visibilidad pública en incremento, con un corrimiento hacia la consideración de lo religioso como dimensión y actor político institucional en nuestra sociedad.

\footnotetext{
${ }^{128}$ Las consideraciones teóricas sobre las interacciones entre acontecimiento y construcción del acontecimiento noticioso señala el hiato existente entre la experiencia personal vivida (Luhmann, 1994; Bateson, 1991; Maturana y Varela, 1996; Varela, 2005) y el proceso de la mediatización que se produce en la construcción de acontecimientos (Verón, 1987, 1993, 1997, 2013). La construcción y reconstrucción de las noticias está planteada en la teoría de Niklas Luhmann (2000, 1994), en particular, en las relaciones sistema-entorno de los medios. El profesor Raúl Barreiros nos hizo reflexionar sobre esta cuestión en un seminario en la UNLP, en 2010.
} 
Si bien en los últimos tiempos, en particular desde 2001, la visibilidad pública y mediática de las manifestaciones de fanatismo religioso lejos de extinguirse han crecido -al menos en el espacio de los medios de comunicación-, el discurso y las instituciones religiosas no guardan ya posibilidades de imponer una 'verdad' que se pretenda única y rigurosa sobre la moral, las costumbres, el dogma, ni de regular la mayor parte de las prácticas sociales, al menos, en las sociedades occidentales contemporáneas (Casanova, 1994; Hervieu-Léger, 1996, 2005).

Con matices y diferentes acentuaciones, la dimensión religiosa forma parte de la vida pública social como uno de los sectores y factores presentes en las luchas por el sentido y por el poder (Casanova, 1994; Hervieu-Léger, 1996, 2005; Mallimaci, 1996, 2008, 2013; Esquivel, 2008; Esquivel y Vaggione, 2015).

En nuestro país, la encuesta que en 2008 realizó y difundió el Programa Sociedad, Cultura y Religión, dirigida por Fortunato Mallimaci y coordinada por Juan Cruz Esquivel, del Centro de Estudios e Investigaciones Laborales (CEIL) perteneciente al CONICET, indica que la Iglesia Católica sigue siendo la institución de mayor confianza entre los argentinos (59\%), seguida muy de cerca por los medios de comunicación con el 58\% (AA.VV., 2008: 9) dentro de parámetros por debajo del 60\% de credibilidad.

En cambio, las iglesias evangélicas (39\%) se ubican en el sexto lugar, luego de las fuerzas armadas (46\%), la policía (42\%) y la justicia (\%40). Con los más bajos índices de confianza institucional figuran, en cambio, el Congreso (36\%), los sindicatos (30\%) y los partidos políticos (27\%).

Consideramos que esta percepción social sobre la Iglesia Católica y los medios de comunicación como las instituciones con mayor credibilidad podría ser producto, entre otros factores, de esa "alianza estratégica" en la arena pública de la construcción de representaciones sociales que enlaza a ambas instituciones y de la que hemos tratado de dar cuenta en esta investigación.

Los medios de comunicación del grupo Clarín, y en menor medida de La Nación, trabajan en estrecho contacto con los principales líderes del Episcopado, al menos, desde tiempos previos a la última dictadura militar argentina. En la práctica del periodismo, su justificación es que estos líderes son una de las fuentes informativas 
privilegiadas pero resulta que, desde el punto de vista eclesiástico, también se prioriza el vínculo con ciertos medios de comunicación como parte de sus estrategias institucionales.

De este modo, no es llamativo que en épocas anteriores las alianzas de la Iglesia Católica argentina hayan sido realizadas también con instituciones que figuraban en los principales lugares de credibilidad en la sociedad, como las Fuerzas Armadas. Si bien esta relación entre militares y clérigos sigue vigente, el Episcopado argentino pareciera otorgarle una gran importancia a los medios y a la comunicación en la sociedad argentina actual (Sivak, 2015: 46-47).

Hemos tratado de analizar algunos rasgos de esas relaciones entre religión y medios en las condiciones de producción (Verón, 1993) de los periódicos Clarín y CL.com, y La Nación y LN.com. En cambio, la posición de Página/12 y P12.com nos ha advertido que un medio de comunicación no puede ignorar las noticias sobre religión, pese a su postura crítica y laica.

La reconfiguración de las relaciones entre cultura y religión (Roy, 2010) en las sociedades contemporáneas también es un rasgo significativo para las múltiples incursiones del discurso religioso en el discurso mediático, al fundirse con la cultura de una sociedad determinada y en el sentido amplio de las representaciones sociales, sus valoraciones éticas y morales.

En el final del milenio han sido popularizados términos como "choque de civilizaciones" (Huntington, 2001), o el postulado "Fin de la Historia" (Fukuyama, 1992). Asistimos con mayor perplejidad a cambios que tras la caída del Muro de Berlín, en 1989, redefinieron el mapa mundial con fenómenos que dieron lugar a lo que se comenzó a llamar globalización, con la popularización de internet y el desarrollo de las nuevas tecnologías de comunicación -como hemos tratado de presentar en el apartado 3.2 de la Presentación conceptual (supra).

El análisis en el que indagamos acerca de las noticias sobre religión en tres diarios digitales y en la comparación con sus correlatos impresos, nos ha advertido acerca de la significación que ocupa el recorte realizado en el período que estudiamos, caracterizado por cierta impronta de las relaciones entre las diversidades religiosas y las 
singularidades de los medios de comunicación seleccionados, en el contexto globalizado y de conexión tecnológica actual.

Esa impronta de los años 2001-2010 se opone a la década de 1990, podríamos decir estilísticamente, en cuanto a las maneras y modos de hacer entre política y religión (Esquivel, 2004). Si bien persisten algunas continuidades y similaridades, hemos destacado la presencia del credo evangélico y la figura del líder católico Jorge Bergoglio, entre las caracterizaciones de las noticias sobre religión y entre las figuraciones de las voces enunciativas principales en el espacio público mediático.

\subsection{El período 2001-2010}

Las relaciones entre religión y política, desde 2001 hasta 2010, inician y finalizan con una fuerte presencia pública de lo religioso que tuvo continuidades de la década previa y diferentes momentos de auge en este período.

En el comienzo de la década, la situación argentina de 2001 fue marcada por la crisis política, social y económica de la caída del gobierno nacional de la Alianza y a nivel internacional por el atentado a las Torres Gemelas, en New York.

Estos acontecimientos reforzaron las construcciones de sentido "apocalípticas", o al menos proféticas, ante el cambio de siglo. La primera década del nuevo milenio finalizó en 2010 según la cronología, con la polémica por los debates y la sanción de la Ley 26.618 que permitió el matrimonio entre personas del mismo sexo, conocida como ley de matrimonio igualitario.

Pese a que algunos cultos no se opusieron a la sanción de la normativa mencionada -por ejemplo, las iglesias protestantes históricas nucleadas en la Federación Argentina de Iglesias Evangélicas (FAIE), las iglesias luteranas, la Iglesia Metodista, la Iglesia Presbiteriana-, el Episcopado católico argentino en alianza con grupos evangélicos pentecostales asumió la representación de 'todos' los sectores religiosos que se oponían a la normativa cuando sólo era una 'parte' e incluso, para algunos, minoritaria en cuanto a la cantidad de fieles que convocaba y representaba. 
Esta estrategia discursiva en el espacio público de los medios, está asociada con la figura retórica de la sinécdoque ${ }^{129}$, que invierte la relación de la parte por el todo y que hemos visto repetir tanto por la Iglesia Católica argentina como por Clarín.

A su vez, la operatoria de convertir lo particular en general es una de las estrategias clásicas por la que, por ejemplo, la Ciudad de Buenos Aires se proclama 'La Ciudad', la provincia de Buenos Aires, 'La Provincia', Clarín "El gran diario argentino" y la Iglesia Católica argentina 'La Iglesia'.

En cambio, en el nombre del diario La Nación opera otra figura retórica como procedimiento. En el planteo de la equivalencia cruzada entre el diario y el país, en el contexto del siglo XIX y de la prensa de facción política actúa el quiasmo ${ }^{130}$ inscripto en el nombre del periódico por el cual, éste se presupone como representante de la nación argentina y viceversa ${ }^{131}$.

De este modo, la figura retórica habilita la comparación entre el diario La Nación y 'la nación' argentina, en esa cadena de reenvíos metafóricos que es el lenguaje (Lakoff y Johnson, 1995) y que permite otro paralelismo, el que iguala a 'la nación (argentina es) católica' con 'La Nación (es) católica'.

A diferencia de los medios de comunicación anteriores, Página/12 pareciera haber elegido su nombre en oposición a la habitual grandilocuencia de las empresas periodísticas: en sus inicios, la página 12 publicaba al pie los datos institucionales del periódico y fue el número inicial de páginas con el que contaba el primer ejemplar. En conjunción con otros rasgos como la ausencia de editoriales propiamente dichos en la

\footnotetext{
${ }^{129}$ La sinécdoque (en griego: $\sigma v v \varepsilon \kappa \delta o \chi \eta ́ ~\left[\operatorname{synekdok}^{\mathrm{h}} \mathrm{e}\right.$ :], 'entendimiento simultáneo') es un tipo de metonimia. La significación del término varía según se entienda como un término específicamente lingüístico o como un tropo retórico.1 (1). En la literatura lingüística, la sinécdoque es el tipo de metonimia en que se designa: (a) El todo por la parte: "Argentina ha jugado bien" por "el equipo de hockey cadete masculino de Argentina que ha alineado hoy el entrenador ha jugado bien". (b) La parte por el todo: "Danos hoy nuestro pan de cada día" por "danos el alimento necesario de cada día"; "en esta familia hay cinco bocas que alimentar"; "el cabeza de familia". (2). Como término retórico puede abarcar además de los usos de (1), algunas figuras relacionadas:La especie es usada por el género. El género es usado por la especie. El material de que algo está hecho es usado por la cosa. (https://es.wikipedia.org/wiki/Sin\%C3\%A9cdoque)

${ }^{130}$ El quiasmo es una figura retórica basada en la repetición. Se trata de un paralelismo cruzado, es decir, de la repetición de una estructura sintáctica... (https://es.wikipedia.org/wiki/Quiasmo)

${ }^{131}$ En sus primeros años, el diario La Nación se llamaba La Nación Argentina; luego ya no fue necesaria la aclaración.
} 
publicación, esta estrategia discursiva apela a la disminución o atenuación: la litote $^{132}$, figura opuesta a la hipérbole.

Volviendo a los contenidos específicos de las noticias que se relacionan con fenómenos sobre religión en los medios indagados, podemos decir que entre esos años se debatió, de 2004 a 2006, y finalmente se sancionó la Ley de Educación Sexual cuya discusión pública protagonizó polémicas en 2004 y 2005 como la del entonces obispo castrense Antonio Baseotto con el ministro de Salud Ginés González García, o las polémicas declaraciones de Jorge Bergoglio respecto a la muestra artística de León Ferrari que incitaron a un grupo de católicos a destruir parte de la obra.

El llamado "conflicto con el campo" en 2008 y las constantes "tensiones" y "gestos" de distensión entre el gobierno y el Episcopado católico argentino fueron otros de los acontecimientos que los medios convirtieron en noticias.

Como en muchas informaciones que tratan sobre fenómenos de religiosidad, el catolicismo predomina en la visibilidad de la escena pública aunque sostenga alianzas interreligiosas en las que los demás cultos suelen aportar la cantidad significativa de fieles en actos públicos, en especial, los grupos evangélicos pentecostales.

En las relaciones entre las iglesias y el Estado es posible observar la presencia de la política en el campo de lo religioso y la presencia de la religión en el campo de lo político. Como parte de la visibilidad pública de las relaciones entre las iglesias de distintos credos y el Estado, las informaciones periodísticas de actualidad sobre la asistencia social demuestran superposiciones entre religión y política: las noticias sobre las campañas de Caritas, pero también el manejo de fondos del Estado por parte de líderes religiosos de distintos credos, en ong's, comedores, y en sus distintas vinculaciones con políticos (Carbonelli, 2015).

Es significativo que se considere clientelismo a las relaciones entre política y pobreza, pero la religión quede exenta de ese calificativo peyorativo, al menos en las noticias de los medios de comunicación que indagamos.

\footnotetext{
132 La atenuación (del latín attenuatio), 1 también denominada litotes, lítotes (del bajo latín litŏtes, y este del griego $\lambda ı \tau o ́ \tau \eta \varsigma) \underline{2}$ o litote (del francés litote), $\underline{3}$ y con menos frecuencia extenuación (del latín extenuatio), $\underline{4}$ es una figura retórica, relacionada con la ironía y el eufemismo, mediante la cual se afirma algo, disminuyendo (atenuando) o negando lo contrario de lo que se quiere afirmar o decir: "No poco" = Mucho. "No está bien" = Está mal. Constituye en realidad una clase de perífrasis o circunloquio. https://es.wikipedia.org/wiki/Atenuaci\%C3\%B3n_(ret\%C3\%B3rica)
} 
A grandes rasgos podemos caracterizar cada medio frente a las temáticas de educación, familia, sexualidad y reproducción sexual a partir de tendencias a favorecer una posición militante (P12 y P12.com), una posición “conservadora” (LN y LN.com) y una posición que reclamaría la intervención y responsabilidad estatal (CL y CL.com), en especial, respecto a la reproducción y salud sexual que involucran las problemáticas del aborto, de la adopción de niños, entre otras.

De la dimensión de análisis Vaticano podemos resaltar algunos rasgos significativos para el análisis de las noticias sobre religión en la Argentina. La presencia de las informaciones internacionales sobre el Vaticano indica el preponderante lugar que ocupa el catolicismo en los tres medios indagados y, a su vez, nos muestra cómo la sede vaticana actúa en sus relaciones con la Iglesia Católica argentina y el rol político que adquieren los cardenales en cada país.

Es significativo que en la construcción de una memoria histórica de corto plazo, que tiene su anclaje en 2001 y a la que suelen referir las noticias, la Iglesia Católica argentina haya sido presentada como una de las "reconstructoras" del país luego de la crisis.

Tal vez sea, como dijimos antes, producto de una alianza exitosa entre el Episcopado católico argentino y los principales medios de comunicación, en particular, el consorcio de medios de los grupos Clarín y La Nación, luego de la década de los noventa y de los cambios en los lugares sociales de ambos grupos, el mediático y el de los líderes de la Iglesia Católica argentina, después de la dictadura argentina de 19761983.

En este sentido las "batallas mediáticas" del gobierno kirchnerista (De Diego, 2015) que instalaron una discusión sobre las retenciones impositivas al campo, la Ley de Medios y otras acciones gubernamentales, como ampliaciones de derechos civiles con la Ley de Matrimonio Igualitario y la Ley de Identidad de Género, o la Ley de Fertilización asistida, no lograron modificar la hegemonía en las relaciones de fuerza de ciertos sectores corporativos -no sólo los mediáticos, muchas veces esos sectores privilegiados formaron alianzas entre sí-, en la Argentina moderna y contemporánea.

Por otra parte, como señala Casanova (1994) verificamos una estrategia del Episcopado católico argentino tendiente a reforzar su rol, en lo que el autor entiende 
como "religión pública"; es decir, una presencia y visibilidad mayor en el espacio público $\mathrm{y}$, en particular, en el espacio público mediático de la información de actualidad.

Como actor social y político, la Iglesia Católica ha perdido injerencia en la vida privada de los individuos (Hervieu-Léger, 1996, 2005), pero como institución ha reforzado los lazos de su presencia en el Estado, de su influencia en la política local y global, de sus recursos para la asistencia social (Mallimaci y Esquivel, 2014), entre otros factores de crecimiento institucional que explicarían también la llegada en 2013 del primer Papa latinoamericano en la figura de un argentino, Jorge Bergoglio, fundamental en la política de nuestro país y en el período estudiado.

\subsection{Caracterizaciones de las noticias sobre religión}

La construcción representacional, hecha en y por los medios de comunicación que indagamos, retoman clasificaciones socio-históricas y teóricas de los sectores eclesiásticos argentinos y proponen una escena enunciativa donde las noticias sobre las relaciones políticas entre la Iglesia Católica y el gobierno se articularían a imagen y semejanza, en analogía podríamos decir, de las distintas facciones representativas en las relaciones políticas del Vaticano, que también tendría sus sectores conservadores, moderados y progresistas.

En esta Tesis hemos indagado acerca del cambio en la denominación de los grupos católicos conservadores, moderados y progresistas que fue una actualización de las clasificaciones previas al Concilio Vaticano II. La denominación preconciliar clasificaba a los sectores religiosos como tradicionalistas, conservadores y renovadores (Esquivel, 2004; Obregón, 2005).

De este modo, los diarios CL y CL.COM, LN y LN.COM en algunas oportunidades construyeron sus noticias "en espejo" respecto de cómo lo hacen las argumentaciones religiosas. Esto puede deberse a que el enunciador-periodista retomaba la palabra de los líderes religiosos y la hacía propia en títulos, bajadas y volantas, o porque el enunciador-diario ha elegido entre las opciones argumentativas la de plegarse al discurso religioso, entre otras variaciones posibles. Observamos en distintas 
oportunidades esta tensión que, de modo comparativo, no se manifestaba en P12 y P12.com dado su supuesto "pluralismo" y laicismo como posición editorial y estilística.

Ahora bien, el discurso y las voces religiosas no pueden estar ausentes en los medios de comunicación. Las declaraciones y acontecimientos ligados a fenómenos de religiosidad -además de celebraciones, procesiones, aniversarios, fallecimientos- son uno de los insumos regulares de la información periodística de actualidad. Como señalaba Eco (1978: 29) para los diarios impresos:

...la industria de la información, por el puro razonamiento del beneficio, lleva a magnificar acontecimientos minoritarios para hacer noticias excepcionales y a repudiar hechos continuos y repetitivos como antiperiodísticos. Por otra parte, la misma naturaleza del medio (un periódico tiene cada día el mismo número de páginas, haya pasado o no alguna cosa interesante) impone a la industria de la información el crear acontecimientos aun cuando no existen. (citado en Rodrigo Alsina, 1993: 40).

Algunos rasgos han cambiado, por ejemplo, ya no hay un número establecido de páginas y existe una proliferación de noticias sobre acontecimientos "minoritarios" debido, en parte, a la digitalización y a la inclusión de informaciones de las redes sociales y sus representaciones.

Sin embargo, el carácter circular en la información periodística tal vez dependa de un modo de funcionamiento propio de la producción de las noticias: al reconstruir los acontecimientos y convertirlos en noticias, los medios retoman las palabras y argumentos de los actores sociales como si fueran "hechos", en el sentido de que constituyen su material empírico para trabajar la información.

El nivel de crítica en estas retomas discursivas diferencia las posiciones de CL.com y LN.com respecto a la de P12.com. En esas retomas hay una apropiación de las palabras del otro, al mismo tiempo que una aceptación implícita y muchas veces acrítica que no cuestiona los usos y los juegos de lenguaje (Wittgenstein, 1989, 1999).

El periodismo no suele reparar en la conciencia internalizada que los actores sociales tienen acerca de la presencia e importancia de los medios de comunicación para sus propias actividades, lo que Verón $(1997,2001)$ ha llamado mediatización. Tal vez si lo hicieran entrarían en una suerte de análisis reflexivo y recurrente acerca de la 
sociedad, que los géneros de la crónica y la noticia no privilegian como sí lo hacen en la construcción de sus referencias ${ }^{133}$.

El grado de autoconciencia en la propuesta enunciativa de incorporar y reproducir las voces y argumentos religiosos es lo que diferencia a CL y CL.com y LN y LN.com, de P12 y P12.com.

Si bien la principal voz enunciativa es la propia voz de cada medio, como hemos visto con las posiciones editoriales y con los rasgos asumidos en cada estilo hacia el interior de las noticias, en particular, las noticias sobre religión plantean una enunciación sui generis en la relación de cada medio con la de los periodistas especializados en religión y con la voz de los actores sociales convocados, sean líderes religiosos o no.

En otras noticias se contraponen diferentes voces enunciativas, se desconfía o presenta como una voz parcial identificada con un sector sociopolítico: tanto LN.COM como CL.COM suelen retomar la voz de diversas figuras de la Iglesia Católica argentina como una voz de autoridad -no así con otros cultos- que se ubican en un lugar superior "por encima" de disputas partidarias y sectoriales.

En cambio, en P12 y P12.COM vemos un cuestionamiento permanente del conservadorismo, en particular del religioso, como parte de las dinámicas de las condiciones de producción de sus noticias.

En este sentido, también decíamos que los cultos no tradicionales tienen una menor visibilidad en el espacio público mediático, mientras que se ha naturalizado el hábito en el que las autoridades de las religiones tradicionales muchas veces son consultadas por las autoridades gubernamentales del país (Mallimaci y Esquivel, 2014; Esquivel, 2008).

\footnotetext{
${ }^{133}$ Por supuesto, es posible y en muchos casos necesario que el análisis periodístico incorpore las herramientas de las ciencias sociales en la construcción de las noticias y en el comentario de las notas de opinión, en la crítica o en el periodismo de investigación, donde el referente se construye al mismo tiempo que se problematiza. En esta Tesis abogamos en ese sentido, pero también hemos observado a lo largo de este trabajo que el mundo de la información tiene sus propias prácticas, rutinas y lógicas productivas distintas a otros mundos sociales como el mundo de la ciencia.
} 


\subsection{Caracterización de los medios indagados}

Observamos que la urgencia informativa por dar a conocer las noticias, por informar a los posibles lectores distingue a CL y CL.com, y los diferencia de los juegos de lenguaje irónicos, satíricos, que identifican la manera de hacer de P12 y P12.com. En LN y LN.com de lo que se trata, en cambio, es de adelantarse a las problemáticas; una suerte de prevención propositiva: 'ante tal problemática es mejor hacer $\mathrm{X}$ ', pareciera enunciar la voz del medio.

De este modo, decíamos cada medio cumple su acción performativa. La Nación tal vez ya no sea "una tribuna de doctrina" en línea con su lema creado por Mitre pero el "adoctrinamiento" y la enunciación pedagógica, todavía persiste en este medio como uno de sus componentes importantes. En este sentido hemos dicho que LN y LN.com practican un periodismo interpretativo: la interpretación valorativa de lo que ellos consideran los "hechos" sociales. Este rasgo es compartido con P12 y P12.com, aunque se opongan en sus estilos.

Los diarios del Grupo Clarín que van desde el propio Clarín pero que incluyen también al diario deportivo Olé y al diario de distribución gratuita en transportes públicos, La Razón, entre otros, reclaman para sí la "objetividad” e “independencia” del periodismo "tradicional" pese a que en otras características son muy distintos en cada uno de sus estilos. En cambio, Página/12 y P12.com se alinean con las búsquedas del Nuevo Periodismo y con las experimentaciones de las décadas de 1960 y $1970^{134}$.

Además de las alianzas institucionales, como en el caso del que hemos dado cuenta con el suplemento Valores Religiosos, Clarín y la Iglesia Católica argentina coinciden en la posibilidad de convertirse en actores políticos opositores al gobierno de turno y ejercer presión para conseguir sus objetivos. Según la periodista Graciela Mochofsky (2011) en la década de los noventa:

Menem había interpretado que construía una alianza con Clarín que le garantizaría una cobertura favorable: promoción de sus actos de gobierno y protección frente a sus errores, desvíos y prácticas más controversiales. Clarín, en cambio, había descubierto

\footnotetext{
${ }^{134}$ Esas experimentaciones también tuvieron su historia local con el libro Operación Masacre de Rodolfo Walsh, el diario La Opinión de Jacobo Timerman, las revistas Primera Plana y Confirmado, la revista Crisis, entre otras. Podemos destacar también las creaciones intelectuales que tuvieron lugar en el Instituto Di Tella de Buenos Aires; en particular, los happenings (Masotta, 1967).
} 
que los políticos en el poder protestan por el diario de hoy pero están pendientes de ganar el de mañana; siempre necesitarán conciliar, llegar a un acuerdo, evitar una ruptura definitiva. Esto significaba que siempre cederían a los pedidos del diario y que, una vez obtenido, no había por qué entregar demasiado a cambio." (Mochofsky, 2011: 111).

En este sentido, Clarín actúa como institución mediática al prever las acciones que pueden generar la publicación de ciertas noticias y comentarios de las noticias, como diario de referencia dominante en la prensa gráfica y digital del sistema nacional de medios (Albornoz, 2006).

Una de las diferencias principales entre un medio de comunicación y un actor social es que el medio genera institucionalidad; en cambio, el actor produce subjetividad. El medio tiene necesariamente un soporte de permanencia material, autónomo al sujeto y de acceso público (Verón, 2013).

Por eso hemos hablado de mediatización: el pasaje de prácticas sociales a los medios y las reconfiguraciones que generan los cambios de escala (Verón, 2001a) mediáticos hacen que la experiencia vivida se transforme en acontecimiento social y el acontecimiento se multiplique y agigante en cuanto a la acción mediática ${ }^{135}$.

De este modo los medios y los géneros discursivos son instituciones sociales que construyen significación a partir de sus usos sociales, en juegos de lenguaje (Wittgenstein, 1999) relativamente establecidos por la construcción de mundos posibles (Goodman, 1990) que alimentan la semiosis social.

Así, los medios ponen en relación a los ciudadanos informados con los actores políticos y sociales (Muraro, 2000). Lo hacen en un espacio público mediático que muchas veces es producto de las representaciones sociales de unos y otros, de sus interacciones, tamizadas, "refractadas" (Bajtín, 1982) por los medios de comunicación. Según la semióloga argentina Lucrecia Escudero Chauvel se trata de:

La verdad mediática. Aquello que es presentado y consumido como real y que tiene la forma de gran relato. Paolo Fabbri dice que los medios se han vuelto paisaje y sería ridículo discutir acerca de la verdad de un árbol. Son las formas de la naturaleza

\footnotetext{
${ }^{135}$ Las obras artísticas conceptuales de la década1960 en la Argentina jugaron con esta posibilidad en el llamado Arte de los Medios, en la Menesunda y en el pop-art, entre otras obras. Primera Plana publicó un happening que consistió en la crítica de una muestra de arte que nunca tuvo lugar, puesto que la obra conceptual era la crítica. Entre otros, véase: Masotta, 1967; Koldobsky y López Barros, 2004.
} 
moderna. Y tal vez una de las fuentes actuales de la historia. Y es en este punto donde la interfase entre discursos bélicos, diplomáticos, políticos o religiosos refleja la polifonía de las voces mediáticas en las que estamos inmersos y se amalgaman en un macrogénero que los sostiene. Apenas nos asomamos a esa extraordinaria industria que es la producción de la información, con sus fuentes, rutinas y estereotipos, el problema de la objetividad de la información no se vuelve más pertinente -es decir, no es la pregunta que debería colocar el investigador- y ésta se desplaza hacia la de la propia lógica de producción del medio, teniendo siempre presente que la primera lealtad de los medios es consigo mismos. (Escudero Chauvel, 2012: 28-29).

Es destacable que las noticias sobre religión no presenten particularidades diferenciadoras respecto al resto de las informaciones en su configuración formal: sí podemos afirmar que es habitual que en la sección política haya un predominio de notas de análisis; en la sección economía, de datos y estadísticas presentes en noticias que tienden hacia el formato del informe; que la sección cultura cuente con mayor presencia de reseñas y entrevistas; que en la sección deportiva predomine la crónica como relato de los partidos y juegos.

Entonces no podemos decir que haya una particular forma de tratamiento de la información en las noticias sobre religión, dado que atraviesan diversas problemáticas, temáticas, agendas y contenidos específicos de la información periodística de actualidad.

Esto no opaca la mayor presencia y visibilidad del discurso religioso en el discurso de la información de actualidad, a partir de acontecimientos que yuxtaponen las creencias sociales con las creencias políticas de una sociedad. Las temáticas y problemáticas que involucran a las religiones tradicionales crecen cada día porque la religión se hace pública (Casanova, 1994) y para contradecir las teorías modernas de la secularización de la sociedad, los líderes religiosos se hacen cada vez más visibles como referentes del entramado público.

La voz de las autoridades religiosas, en especial las de los credos tradicionales y en nuestro objeto de estudio, las voces del catolicismo, son una de las fuentes privilegiadas de las noticias y colaboran en determinar sus sesgos. Los líderes religiosos son parte de los actores políticos que entran en juego en el sistema de los medios como "lugar de confrontación entre diferentes actores" (Rodrigo Alsina, 1993: 37). Ese lugar 
de confrontación es lo que podríamos denominar espacio público propiamente mediático.

Sin embargo, como decíamos al comienzo de estas conclusiones, el fenómeno y proceso descripto con el término globalización provoca, entre otras cosas, que las sociedades también compartan sus "esferas públicas":

Pero lo que aquí importa señalar, sobre todo, es que especialmente el "espacio público social" no obedece en absoluto a las fronteras nacionales de cada "sociedad civil". En el marco de representación que proporciona el espacio público a las sociedades humanas, las sociedades civiles, políticamente delimitadas por las fronteras de Estadosnacionales, no obstante penetran sin problema unas en otras, de modo que el espacio público no es sólo el lugar de la comunicación de cada sociedad consigo misma sino también, y quizás ante todo, el lugar de una comunicación de las sociedades distintas entre sí. (Ferry, Wolton y otros, 1998: 20).

La participación ritual del público (Gomis, 1991; Rodrigo Alsina, 1993) que, como sostiene Jean-Marc Ferry (Ferry, Wolton y otros, 1998: 20) “...el público es, virtualmente, toda la humanidad...", crece en el género de opinión como parte de la producción de las noticias y de sus comentarios, casi en simultáneo con la recepción de las informaciones a partir de las redes sociales y con los comentarios de lectores en los espacios de los diarios digitales (Diéguez, 2015), entre otras formas posibles de "estar" en internet en sus configuraciones actuales.

Además, la participación ritual en los comentarios de lectores genera una suerte de "liturgia" de las noticias (Gomis, 1991) y las reacciones de la opinión pública reactualizan, de manera metafórica, la función del coro (Ander Egg, 1983: 316) como una presencia constante en la escena pública de la representación.

\subsection{Los "viejos" y "nuevos" medios con internet}

Antes de internet, la existencia del sistema de medios de comunicación argentino era algo relativamente estable. Los medios se retroalimentaban en sus informaciones a lo largo de la jornada: la prensa gráfica que incluía a las revistas y algunos otros 
impresos dominaba la mañana junto con la radio, y la televisión retomaba el trabajo informativo a partir del mediodía y la tarde.

La prensa generalista y la prensa especializada (Wolton, 1992; Scolari, 2008; Carlón y Scolari eds., 2009) fue otra de las divisiones en ese sistema mediático que estalló con internet.

En el caso de la radio, la frecuencia am/fm implicaba su alcance y la oposición respectiva entre los medios nacionales/locales. Un supuesto "target" joven en la fm, adulto en la am, caracterizado por el predominio de la música, por cierta tonalidad y cadencia en las maneras de hablar, por cierta modalidad periodística -que en la am le debía su organización al guión radiofónico, a su lectura, y en la fm a la "improvisación".

En el caso de la televisión nacional primero se desarrolló la de transmisión abierta; luego la de cable, paga y especializada en públicos "fragmentados", con canales de películas o canales de noticias, entre otras propuestas. Después, la televisión satelital permitió incorporar canales de variados países en un modo de transmisión que trascendía la distribución terrestre del cable, ya que gracias a la antena satelital, su señal podía captarse desde cualquier lugar.

Este "ecosistema" mediático (Scolari, 2008) fue alterado por la existencia de internet y sus posibilidades. La prensa gráfica ya no dependió más sólo de su soporte impreso: al tener una edición online no la afectaba el cierre de edición, ni la distribución física del objeto "diario" ni las huelgas de los trabajadores de prensa, repartidores, etcétera.

Con internet, la radio terminó de cancelar esa barra que separaba la fm de la am ya horadada por las mezclas y transposiciones de estilos y géneros (Steimberg, 2013), si bien algunos de sus rasgos y de sus maneras de hacer perduraron y perduran todavía. La televisión fue rearticulada por internet ya que las diferencias entre aire, cable y satélite se relativizaron con la web.

Las relaciones entre "viejos" y "nuevos" medios empezaron a alterar el ecosistema mediático y modificaron tanto a los medios de la transmisión de ondas y señales de audio y video, los de la era del broadcasting, como a los medios de la era de internet. 
El caso del cine también fue significativo en su doble estatuto de medio de comunicación con productos no ficcionales, como los primeros noticieros y los documentales, y como medio de expresión artística con sus productos ficcionales organizados en un sistema de géneros clásicos -western, policial, drama, comedia- y sus estilos de época, de director, regional, además de sus fusiones posibles. El cine en dvd reformuló el video, tanto como Youtube y Netflix lo hicieron con las series y la televisión (Carlón y Scolari, 2009; Sorlin, 2004).

No sólo cambiaron los medios y seguirán cambiando, también cambió la relación de esos medios con lo local, lo nacional y lo global. Sus funciones informativas se reconfiguraron con la llamada prensa digital, la radio digital y la televisión digital. En verdad "lo digital" sólo era el proceso por el que esos "viejos" medios pasaron a integrar, con internet, nuevas convivencias que modificaron los usos mediáticos.

Desde entonces, el fragmento radial o televisivo pudo estar en el mismo espacio que la noticia escrita. El "diario digital” no dejó de ser una plataforma, un sitio o página web, que como cualquier otra página o sitio, sea llamado blog o como fuera, puede reunir en su espacio fragmentos de información (en el sentido de la combinación en el lenguaje informático de 0 y 1) convertidos en bytes.

\subsection{Las paradojas de la 'edición impresa' en la edición digital}

Las interrelaciones entre diario impreso y diario digital hacen que el último haya sido una transposición del primero. A la vez que ambos ya se perfilaban en sus condiciones de producción, en especial, pero también en sus recepciones, como medios distintos por su soporte y por sus dispositivos: el diario de papel organiza sus espacios y discursos en el diseño gráfico, la tipografía y fotografía impresa. En cambio, la configuración informativa del diario digital presupone el uso y la lectura en la pantalla multimedial.

Es cierto que, como hemos dicho a lo largo de este análisis, la edición digital todavía reenvía a la edición en papel por la identificación simbólica del medio: por su logo, por los títulos y su tipografía, por los colores, por las firmas de los periodistas (Boczkowski, 2006; Scolari. 2008; Verón, 2013) entre otros rasgos enunciativos que 
construyen la imagen del posible lector que seguiría identificando a Clarín y CL.com, a La Nación y LN.com, a Página/12 y P12.com.

A la morfología de la primera página (Rodrigo Alsina, 1993: 17) se suma el contacto del ojo con la portada impresa como entrada privilegiada al diario de papel (Steimberg y Traversa, 1997). En cambio, con el diario digital no hay cierre de edición, la distribución ya no depende del transporte de mercancías pero sí de los servidores continuos de internet, del flujo de la información ininterrumpida (Diéguez, 2010, 2015).

Los diarios digitales son resultado de su emplazamiento en internet como un proceso de transposición que, a partir de 1995, a la par que se popularizaba la web, ganaban autonomía al convertirse en un medio relativamente nuevo (Boczkowski, 2006).

El diario digital incluye rasgos de otros medios y otros dispositivos en sus condiciones de producción y modifica muchas características de los diarios de papel gracias a los componentes de multimedialidad, interactividad, reticularidad, hipertextualidad y digitalización (Scolari, 2008), que el soporte de la web permite sumar.

Por estas mismas razones, los diarios digitales no pueden ser sólo la "versión electrónica" de los diarios de papel ya que el nuevo emplazamiento modifica radicalmente lo que llamamos diario impreso; pero tampoco pueden dejar de serlo, ya que la correlación identifica los nombres, los logos y algunas características estilísticas permanecen mientras otras cambian.

Esta doble indeterminación que mencionamos es probable que produzca como hipótesis a corroborar en un análisis de las condiciones de reconocimiento (Verón, 1993, 2013) que gran parte de los lectores considere a los diarios digitales como una "versión electrónica" aunque cada vez más internautas perciban las diferencias, incluso las diferentes estrategias que utilizan los medios online y offline -como es notable por sus dos estilos bastante disímiles en el caso de La Nación y lanacion.com.

En este sentido, hablamos de la permanencia de un correlato entre la edición digital y la edición en papel, ya que el término edición permite dar cuenta de cambios en el "viejo" medio de comunicación llamado diario impreso y en el "nuevo" medio llamado diario digital. 
Lo que no ha cambiado y se ha acentuado es la aceleración (Virilio, 1997) de la periodicidad de las noticias, de la diaria "necesidad" de estar provistos de informaciones de actualidad. Lo que configura un verosímil imposible de la definición de noticia:

Bertrand Russell propone que las escuelas enseñen el arte de leer los diarios con incredulidad. Pienso que esta disciplina socrática no sería inútil. De las personas que conozco muy pocas la cumplen. Se dejan engañar por artificios tipográficos o sintácticos: piensan que un hecho ha sucedido porque está impreso en grandes letras negras, confunden la verdad con el "cuerpo 12", no quieren entender que la afirmación "Todas las tentativas de los atacantes para avanzar hacia B se han frustrado sangrientamente", es un mero eufemismo para admitir la pérdida de B.

Jorge Luis Borges $(1980)^{136}$.

${ }^{136}$ Citado en Escudero Chauvel, 2012: 13. 


\section{Conclusiones comparativas sobre los medios de comunicación indagados}

A lo largo de este trabajo hemos observado que las relaciones y las modalidades de las informaciones periodísticas sobre religión cambian de manera significativa en cada medio analizado. No tanto por las temáticas que abordan las noticias, sino más bien por los modos de sus tratamientos y por los estilos mediáticos, es decir, en cuanto maneras de hacer (Steimberg, 1993, 2013) que cada diario digital y cada diario impreso elabora.

Incluso hemos advertido la imposibilidad de que no haya diferencias entre las ediciones gráficas y las digitales de LN y LN.com, CL y CL.com, P12 y P12.com, así como la imposibilidad de que este último medio deje de tratar las noticias sobre religión.

Las capacidades y restricciones técnicas que la edición digital tiene respecto de la edición impresa (diferencias entre los soportes impreso/digital) también se relacionan con las capacidades y restricciones discursivas (noticias sobre religión como uno de los tópicos temáticos presentes en todo medio).

La conjunción de lo técnico y lo discursivo es lo que hemos descripto en términos de dispositivo (Traversa, 2001) al que se suman las prácticas sociales regulativas del medio, ya sea la llamada "liturgia" de la lectura individual (Gomis, 1991; Rodrigo Alsina, 1993), o el "culto" moderno de la información (Roszak, 1988).

Aunque sospechemos que se trata de reenvíos metafóricos propios de la intersección de campos sociales con prácticas diversas, no deja de ser llamativo el lugar cuasi "religioso" de la comunicación en la contemporaneidad. El teórico argentino Diego Levis (1999) habla de mesianismo para relacionarlo con la tradición de la teoría cibernética creada por Norbert Wiener y, en términos más amplios, con la tradición cartesiana:

... la culminación provisional de un largo recorrido que lleva al encuentro del imaginario y la tecnología en la secular aspiración de crear un ser a imagen y semejanza del hombre, basándose en un modelo conceptual en el que lo humano se reduce a la inteligencia y ésta a la capacidad de tratamiento de la información. El resultado es un ser desprovisto de su dimensión biológica y espiritual, cuya identidad física, siguiendo la concepción cartesiana, no consiste en la materia de la que está compuesto, sino en la información que contiene. 
De este modo, los seres artificiales, la teoría matemática de la información y el racionalismo cartesiano se dan la mano en una máquina automática que, omitiendo la intermediación sensorial del cuerpo, pretende reproducir los mecanismos lógicos del cerebro humano, efectuando los cálculos más sencillos y los más complejos a través del tratamiento de información binaria. Un golem para la era de incertidumbre en la cual nació, hecho de silicio, acero y plástico: el ordenador. (Levis, 1999: 32)

Volviendo a nuestro objeto de estudio, si la entrada al diario de papel es por el contacto entre el ojo humano con lo impreso -y en esto se definía su carácter de "prensa gráfica"podríamos decir que la entrada al diario digital necesita de su paso, y su uso, por y en internet.

Además de las diferencias de la disposición técnica entre lo impreso y las textualidades digitales (Chartier, 2008), el entorno informático de internet suma una complejidad hipertextual que pone en contacto al diario, en tanto "viejo" medio (Igarza, 2008; Scolari, 2008) con una cantidad de referencias, fuentes, reenvíos, archivos, para el lector-usuario contemporáneo (Dorcé, 2009; Canclini, 2009).

La selectividad de la información se convierte entonces en uno de los modos en que los diarios digitales reconfiguran no sólo la agenda de temas públicos en una sociedad sino también el acceso, la distribución y la publicación de las informaciones, que consideran importantes. La distribución física por el espacio de la ciudad, vital para el diario de papel, ha cambiado con el diario digital tal como el correo tradicional lo ha hecho con el correo electrónico.

Además, la digitalización y el entorno informático permiten "ingresar" de manera figurada a los espacios textuales de la información periodística de actualidad (Chartier, 2008; Scolari, 2008; Diéguez, 2012, 2015). En este sentido, internet también ha reconfigurado el polo de la recepción y el consumo de las noticias.

Bajo la forma de los comentarios de lectores, de las redes sociales, cada lectorusuario tiene la posibilidad metafórica de atravesar y romper el antiguo "espejo" social de las noticias (la ilusión de la representación), para formar parte de esos espacios de producción de un fragmento de la realidad social. El espacio público así construido por los medios sólo forma parte de los procesos de producción mediáticos y de acotados colectivos de identificación (Verón, 2004). 
Hemos llamado mundos posibles (Goodman, 1990) a los conglomerados de significación social de la información deportiva, de la información política, de la información económica, de la información internacional, de la información sobre la moda y también, entre ellos, al mundo de la información religiosa. Cada uno de estos mundos posee sus lógicas propias, al modo en que sucede en las esferas de la praxis humana en la teoría weberiana (Esquivel, 1999; Aron, 1992; Giddens, 1994).

Las noticias sobre religión tienen la particularidad de atravesar diversas secciones y géneros discursivos del mundo de la información religiosa. Las informaciones periodísticas sobre fenómenos de religiosidad pueden estar presentes, como hemos analizado, bajo el género de la crónica en la sección Sociedad, por ejemplo, a partir de las peregrinaciones a Luján; bajo la forma de noticia en la sección Internacionales, entre las informaciones sobre el Vaticano, o en la sección política, como la entrevista a un líder religioso, entre otras modalidades posibles.

En cuanto a los modos o maneras de hacer, podemos decir que hemos llegado a caracterizar a Clarín y CL.com por un estilo cercano a lo "popular", en su relevo histórico de los diarios Crítica, La Razón y La Prensa. Preocupado por la claridad y sencillez en el modo de construir las noticias para destacar la urgencia y el impacto de cada información según su lema "Un toque de atención para la solución argentina de los problemas argentinos" $" 137$.

En cambio, La Nación y LN.com han privilegiado la interpretación de la información sobre la actualidad y en esto coinciden con Página/12 y P12.com. El estilo de La Nación, tanto en su edición digital como impresa, privilegia el componente propositivo y pedagógico a partir de su goce clasificatorio (Diéguez, 2010) del mundo social: impone una grilla ordenadora de los acontecimientos que se transforman en noticias. En esto se acerca a los grandes diarios de la prensa "seria" o blanca -por oposición a la prensa amarilla o "sensacionalista"- y conservadora, como Le Monde en

\footnotetext{
${ }^{137}$ Es una reformulación del lema "Un gobierno argentino de soluciones argentinas para problemas argentinos" que usaba durante su gestión el gobernador de Buenos Aires, Manuel Fresco, de quien Roberto Noble fue, antes de fundar Clarín, ministro de gobierno. El componente nacionalista de esta propuesta enunciativa ha dejado de ser significativo para el grupo mediático con el paso del tiempo (Sivak, 2015; Mochofsky, 2011).
} 
Francia o The Washington Post en USA, que coinciden en una fuerte diagramación geométrica y convencional ${ }^{138}$.

De manera complementaria y hasta opuesta al modo en que lo hacen LN y LN.com, Página/12 en su edición digital e impresa privilegian la relación irónica y satírica (Gonzalez, 1992) con la actualidad a partir de la propuesta de lo que hemos llamado "juegos de lenguaje" en múltiples referencias a la cultura y a la información política para sus lectores posibles. En este sentido, su estilo, irónico y satírico, se diferencia y opone al de LN y LN.COM donde lo interpretativo está en función pedagógica.

Cada uno de los medios indagados construye una relación particular con los acontecimientos y con la noticiabilidad de esos acontecimientos. Los mundos posibles tienen la posibilidad de combinarse en la creación de nuevas maneras de hacer mundos, según plantea Nelson Goodman (1990), y esto explica también la irrupción posible de la novedad y del cambio.

De este modo podemos decir que las referencias al país, la ciudad y el mundo que construyen P12 y P12.com, CL y CL.com, LN y LN.com, son relativamente diferentes. La información de actualidad religiosa es una noticia inevitable para P12 y P12.com, una noticia urgente para CL y CL.com, una noticia prevista para LN y LN.com.

Las problemáticas que encierran también son distintas de acuerdo a la perspectiva de cada medio: un motivo de "militancia" a favor de los derechos sociales y humanos para P12 y P12.com, un "objetivo" de acuerdos, negociación, pujas de poderes políticos y sociales para CL y CL.com, un "programa" de propuestas y reformas para LN y LN.com.

Para concluir, podemos decir que los estilos mediáticos, los géneros noticiosos y las secciones informativas se combinan para crear lo que llamamos la información periodística de actualidad religiosa o, brevemente, las noticias sobre religión. Cada medio, además, lo hace de un modo particular que es resultado de sus tradiciones, prácticas periodísticas y propósitos enunciativos, entre los que destaca la posición

\footnotetext{
${ }^{138}$ Según el historiador del arte Wilhelm Worringer: “...todo convencionalismo es también conservador” (Worringer, 1977: 21).
} 
editorial y las identificaciones con los estilos periodísticos y culturales previos a cada medio.

Desde nuestro punto de vista parece inevitable la existencia de una diversidad de creencias y prácticas religiosas que exceden los marcos regulatorios de las grandes religiones históricas monoteístas. Incluso hacia el interior del propio cristianismo y también del catolicismo existe diversidad entre sus sectores conservadores, moderados y populares, entre los movimientos carismáticos y políticos de diversa orientación ideológica (Esquivel, 2004; Giménez Beliveau, 2008).

El período 2001-2010 estuvo signado por una fuerte hegemonía de la presencia pública del catolicismo argentino, que reformuló la visibilidad sobre su participación pública durante la década de 1990 y la reconvirtió, otra vez con éxito, en su habitual papel de "reserva moral de la nación", con la crisis de 2001, en continuidad con sus momentos de mayor esplendor durante el siglo XX.

En 2001, la Iglesia Católica argentina avistó el conflicto social y se posicionó como una de las voces críticas del sector político. Con lo cual hizo dos operatorias que ya hemos señalado: sustraer su pertenencia como actor político institucional y posicionarse por encima de los demás sectores -incluso de sus competidores religiososen la escena social pública. Es significativo que en la construcción de una memoria histórica de corto plazo, que tiene su anclaje en 2001 y a la que suelen referir las noticias, la Iglesia Católica argentina haya sido presentada como una de las "reconstructoras" del país luego de la crisis.

Los fenómenos sociales en relación con la pobreza y la asistencia social abordados por los medios como acontecimientos para ser convertidos en noticias han hecho que la presencia pública de lo religioso tuviera una amplia y continua visibilidad en el espacio público mediático durante la década de 2001-2010.

Cobra magnitud, retrospectivamente, el nombre de Jorge Bergoglio como una de las principales figuras catalizadoras de los acontecimientos sucedidos en nuestro país y construidos como noticias sobre religión en el período 2001-2010, así como el vínculo que lo une a la sede católica y que lo llevará a conducirla, a partir de 2013, como Papa Francisco. En relación con esto, el corpus sobre la palabra clave cardenales dentro de la dimensión de análisis Vaticano fue uno de los más densos en la cantidad de noticias publicadas por Clarín y CL.COM. 
Si bien la principal voz enunciativa es la propia voz construida por cada medio, como hemos visto con las posiciones editoriales y con los rasgos asumidos en cada estilo hacia el interior de las noticias, en particular, las noticias sobre religión plantean una enunciación sui generis en la relación de cada medio con las construcciones representacionales de las voces de los periodistas especializados en religión y con la voz de los actores sociales convocados, sean líderes religiosos o no.

En otras noticias se contraponen diferentes construcciones de las voces enunciativas, se desconfía o presenta de las voces parciales identificadas con sectores sociopolíticos. En este sentido, tanto LN.COM como CL.COM suelen retomar las declaraciones públicas de diversas figuras de la Iglesia Católica argentina, en particular de su Episcopado, como una voz de autoridad que se ubican en un lugar superior "por encima" de disputas partidarias y sectoriales - no sucede lo mismo con otros cultos.

En cambio, en P12 y P12.COM vemos un cuestionamiento permanente del conservadorismo, en particular del religioso, como parte de las dinámicas de las condiciones de producción de sus noticias. El grado de autoconciencia en la propuesta enunciativa de incorporar y reproducir las voces y argumentos religiosos es, también, uno de los rasgos que diferencia a CL y CL.com y LN y LN.com, de P12 y P12.com. 


\section{Referencias bibliográficas}

ANDER EGG, E. (1983), Técnicas de investigación social, Humanitas, Buenos Aires. (1985), Apuntes para una historia del Trabajo Social, Humanitas, Buenos Aires.

ARON, R., (1992), Las etapas del pensamiento sociológico II, Siglo Veinte, Buenos Aires.

AA.VV. (1996), Sociología de la religión, Editorial Docencia, Buenos Aires.

AA.VV. (1982), La nueva comunicación, selección e introducción de Yves Winkin, Kairós, Barcelona.

AA.VV. (2008), "Primera Encuesta sobre Creencias y Actitudes Religiosas en la Argentina", dirigida por el Dr. Fortunato Mallimaci y coordinada por el Dr. Juan Cruz Esquivel, Programa Sociedad, Cultura y Religión del Instituto CEIL- CONICET. Disponible en: http://www.ceil-conicet.gov.ar/investigacion/sociedad-cultura-yreligion/linea-1-religion-y-estructura-social/primera-encuesta-sobre-creencias-yactitudes-religiosas-en-argentinal

AA.VV., (2009) Pensar lo contemporáneo: de la cultura situada a la convergencia tecnológica, Anthropos-UAM, México.

ABÉLĖS, M. (2012), Antropología de la globalización, Del Sol, Buenos Aires.

ALABARCES, P. (2001), “¿La vida por Batistuta? Ciudadanía y narrativas nacionales en el fútbol argentino contemporáneo (y en su televisión)", en: Globalización y nuevas ciudadanías, Reigadas, M.C., y Cullen, C.A. (coord.), Ediciones Suárez, Mar del Plata. ALAYÓN, N. (1992), Historia del Trabajo Social en Argentina, Espacio Editorial, Buenos Aires.

ALBORNOZ, L. (2006), Periodismo digital: los grandes diarios en la Red, Buenos Aires, La Crujía.

ALGRANTI, J.M. (2010), Política y religión en los márgenes. Nuevas formas de participación social de las mega-iglesias en la Argentina, Ediciones Ciccus, Buenos Aires.

ALONSO, G. (2003), La secularización de las sociedades europeas, en: Historia Social, núm. 46, pp. 137-157, España. 
AMEIGEIRAS, A. (2008), "La participación de la Iglesia Católica en la Mesa del Diálogo Argentino: pujas y tensiones en un "espacio espiritual".", en: AMEIGEIRAS, A., y MARTÍN, J.P. (editores), Religión, política y sociedad: pujas y transformaciones en la historia argentina reciente, Prometeo Libros, Buenos Aires.

ARON, R. (1992), Las etapas del pensamiento sociológico II, Siglo Veinte, Buenos Aires.

AUYERO, J. comp. (1997), ¿Favores por votos? Estudios sobre clientelismo político contemporáneo, Losada, Buenos Aires.

(2001). La política de los pobres. Las prácticas clientelares del peronismo, Editorial Manantial, Buenos Aires.

(2002), "Clientelismo político en Argentina: doble vida y negación colectiva", Perfiles latinoamericanos, Junio Nro 020: pp, 35-52.

-(2007) La zona gris. Violencia colectica y política partidaria en la Argentina contemporánea, Buenos Aires, Siglo XXI.

AUZA, T. (1985), Católicos y liberales en la generación del ochenta, Ediciones Culturales Argentinas, Buenos Aires.

AUSTIN, J. L. (1971), Cómo hacer cosas con palabras: palabras y acciones, Paidós, Buenos Aires.

BECERRA, M. y MASTRINI, G. (2006a), Periodistas y magnates: estructura y concentración de las industrias culturales en América Latina, Prometeo, Buenos Aires.

BECERRA, M. y MASTRINI, G., (2006b) "La economía política de la comunicación vista desde América Latina" en Revista Compos 2/20, diciembre 2006.

BARREIROS, R. (2011), “Límites de la mediatización”, en: Cuaderno de cátedra: Comunicación y Cultura. Cátedra I, Ediciones de Periodismo y Comunicación, Universidad Nacional de La Plata, La Plata.

BARTHES, R. (2003), Variaciones sobre la escritura, Paidós, Buenos Aires

(1989), "Variaciones sobre la escritura”, trad. de R. Campa, Sudamericana.

(1987), "La muerte del autor", El susurro del lenguaje. Más allá de la palabra y la escritura, Paidós, Barcelona.

(1991), "Introducción al análisis estructural de los relatos", en: A.A.V.V., Análisis estructural del relato, Premiá, México D.F.

(1993), La aventura semiológica, Paidós, Barcelona. 
BAJTíN, M. (1982), Estética de la creación verbal, Siglo XXI, México.

BATESON, G. (1991), Pasos hacia una ecología de la mente, Planeta-Carlos Lohlé.

BAUMAN, Z. (2002), Modernidad líquida, Fondo de Cultura Económica, Buenos Aires.

BAZIN, A. (1990), "Ontología de la imagen fotográfica" ¿Qué es el cine?, Rialp, Madrid.

BECK U. y BECK GERNSHEIM E. (2003), La individualización. El individualismo institucionalizado y sus consecuencias sociales y políticas, Paidós, Barcelona.

BELL, D. (1976), Las contradicciones culturales del capitalismo, Alianza, Madrid.

BENVENISTE, E. (2002), Problemas de lingüística general l y II, Siglo XXI, México.

BERGER, P. (1999), El dosel sagrado, Kairós, Barcelona.

BERGER, P. y LUCKMANN, T. (2001), La construcción social de la realidad, Amorrortu, Buenos Aires.

BLANCARTE, R. (2008), Los retos de la laicidad y la secularización en el mundo contemporáneo, México, El Colegio de México, Centro de Estudios Sociológicos.

BOCZCOWSKI, P. (2006), Digitalizar las noticias. Innovación en los diarios online, Buenos Aires, Manantial.

BOKSER LIWERANT, J (2008), en: Blancarte, R.J. (coord..), Los retos de la laicidad y la secularización en el mundo contemporáneo, El Colegio de México, Centro de Estudios Sociológicos, México D.F.

BORRAT, H. (1989), "El periódico, actor del sistema político", mimeo. Disponible en http://ddd.uab.cat/pub/analisi/02112175n12p67.txt

BOURDIEU, P. (2000), Intelectuales, política y poder, Eudeba, Buenos Aires.

(2010), El sentido práctico, Siglo Veintiuno, Buenos Aires.

BOURDON, J. "Sobre cierto sentido del tiempo, o de cómo la televisión conforma la memoria", en: Revista Figuraciones 1/2, Instituto Universitario Nacional del Arte, Buenos Aires, 2003.

BOTANA, H. (1977), Memorias. Tras los dientes del perro, A. Peña Lillo Editor, Buenos Aires. 
CABRERA, D. (2006), Lo tecnológico y lo imaginario: las nuevas tecnologías como creencias y esperanzas colectivas, Biblos, Buenos Aires.

CABRERA PAZ, J. (2009), "Convergencia: tecnologías del contacto", en: AA.VV., Pensar lo contemporáneo: de la cultura situada a la convergencia tecnológica, Anthropos-UAM, México.

CALABRESE, O (1994), La era neobarroca, Cátedra, Madrid.

CALINESCU, M (1991), Cinco caras de la modernidad, Tecnos, Madrid.

CANCLINI, N. (1990), Culturas híbridas, Grijalbo, México.

CARBALledA, A. J.M. (2002), La Intervención en lo Social, Paidós, Buenos Aires. (2008), Los cuerpos fragmentados. La intervención en lo social en los escenarios de la exclusión y el desencanto, Paidós, Buenos Aires.

(2006), El trabajo social desde una mirada histórica centrada en la intervención, Espacio Editorial, Buenos Aires.

CARBONELLI, M. (2015), "Pan y palabras. La inserción evangélica en la gestión pública Argentina", Religião e Sociedade, Rio de Janeiro, 35(2): 73-95.

CARBONELLI, M. y MOSQUEIRA, M. (2008). "Luis Palau en la Argentina: Construcción mediática del cuerpo evangélico, disputas por el espacio público y nuevas formas de territorialidad", en: Revista ENFOQUES XX, 1-2, 153-175.

CARBONELLI, M. e IRRAZABAL, G., (2009), "Católicos y evangélicos ¿alianzas religiosas en el campo de la bioética en Argentina?", en: http://www.ram2009.unsam.edu.ar/GT/GT\%2056\%20-

\%20Religiones \%20en\%20Transformación\%20en\%20las\%20Ciudades\%20Latinoameri canas/GT56\%20-\%20Ponencia\%20[Carbonelli-Irrazabal].pdf

CARLÓN, M. (2006), De lo cinematográfico a lo televisivo: Metatelevisión, lenguaje y temporalidad, La Crujía, Buenos Aires.

CARLÓN, M. y SCOLARI, C. A., eds. (2009), El fin de los medios masivos. El comienzo de un debate, La Crujía, Buenos Aires.

CASANOVA, J. (1994), Religiones públicas en el mundo moderno, PPC, Madrid. 
CASTEL, R. (1997), Las metamorfosis de la cuestión social. Una crónica del salariado, Paidós, Buenos Aires.

CASTELLS, M. (1998), La era de la información: economía, sociedad y cultura, Alianza, Madrid.

(2009), Comunicación y poder, Alianza, Madrid.

CASSIRER, E. (1967, [1944]), Antropología filosófica, Fondo de Cultura Económica, México.

CATTOGIO, S. (2016), Los desaparecidos de la Iglesia: el clero contestatario frente a la dictadura, Siglo XXI, Buenos Aires.

CECCHINI, D. y MANCINELLI, J. (2010), Silencio por sangre, Miradas al Sur, Buenos Aires.

CERIANI CERNADAS, C. (2013), «Diversidad religiosa y pluralismo espiritual: notas para repensar las categorías y sus dinámicas de producción», Corpus [En línea], Vol 3, No 2 | 2013, Publicado el 20 diciembre 2013, consultado el 30 septiembre 2016. URL: http://corpusarchivos.revues.org/582 ; DOI : 10.4000/corpusarchivos.582

CHARADEAU, P. (2003), El discurso de la información, Gedisa, Barcelona.

CHARTIER, R. (1992), El orden de los libros, Gedisa, Barcelona. -(2008), Escuchar con los ojos a los muertos, Katz, Buenos Aires.

CHOMSKY, N. (1998), El conocimiento del lenguaje, Altaya, Madrid.

CIPRIANI, R. (2011), Manual de sociología de la religión, Siglo Veintiuno, Buenos Aires.

COLABELLA, L. (2009), Fazer política ou lutar pelo social. Uma etnografia das formas de redistribuição da Grande Buenos Aires. Tese de Doutorado. PPGAS-MN- UFRJ.

(2010), "Patrões e clientes ou redistribuição entre iguais? Uma reflexão sobre clientelismo e suas transposições contextuais". En: Revista Mana. Estudos de Antropologia Social, 16(2), pp.287-310.

CRARY, J. (2015), 24/7 El capitalismo tardío y el fin del sueño, Paidós, Buenos Aires. DARNTON, R. (2000), La gran matanza de gatos y otros episodios en la historia de la cultura francesa, Fondo de Cultura Económica, México. 
DE DIEGO, J. (2014), La prensa escrita durante el gobierno de Néstor Kirchner, Tesis del Doctorado en Ciencias Sociales de la UNLP, inédita, versión electrónica disponible en: http://sedici.unlp.edu.ar/handle/10915/44362.

DENNETT, D. (1995), La conciencia explicada, Paidós Ibérica, Barcelona.

DE KERCKHOVE, D (1999), La piel de la cultura: investigando la nueva realidad electrónica, Gedisa, Barcelona.

DERRIDA, J. (1994), Mal de archivo. Disponible en: www.derridaencastellano.com

DE SAUSSURE, F. (1993), Curso de lingüística general, Planeta-De Agostini, Barcelona.

DIÉGUEZ, F. (2004), El pasaje de operaciones artísticas a los medios, Tesis de grado, Facultad de Periodismo y Comunicación social, Universidad Nacional de La Plata (inédita).

(2007), “¿Hay crítica en Internet?”, en: Anuario de Investigaciones 2006, Facultad de Periodismo y Comunicación Social, Universidad Nacional de La Plata; La Plata.

(2010), “¿Cuándo hay crítica?: Desplazamientos y posiciones de las discursividades de la crítica en los diarios digitales clarin.com y lanacion.com.ar", Actas del VIII Congreso Nacional y III Internacional de la Asociación Argentina de Semiótica "Cartografía de Investigaciones Semióticas", 6, 7 y 8 de octubre de 2010, Ciudad de Posadas, Misiones.

(2011), "Los géneros y los estilos insisten en los medios", Cuaderno de cátedra: Comunicación y Cultura. Cátedra I, Ediciones de Periodismo y Comunicación, Universidad Nacional de La Plata, La Plata.

(2012), "Posiciones ideológicas y categorías del pensamiento racial en los comentarios de lectores de lanacion.com", en: Revista de Antropología Experimental, Universidad de Jaén, Jaén, http://www.ujaen.es/huesped/rae/articulos2012/07dieguez12.pdf

(2014), "Las recomendaciones de Club La Nación y 365 Clarín en la construcción del gusto y la experiencia estética urbana contemporánea", Actas de las XVIII Jornadas Nacionales de Investigadores en Comunicación, Red Nacional de Investigadores en Comunicación (REDCOM), Ciudad de Buenos Aires. 
- (2015), "El conservadurismo religioso en los lectores de lanacion.com", capítulo de libro en: ESQUIVEL, JC y VAGGIONE, JM, (directores) Permeabilidades activas, Biblos, Buenos Aires.

DI STEFANO, R. (2013), « El monopolio como espejismo », Corpus [En línea], Vol 3, No 2 | 2013, Publicado el 20 diciembre 2013, consultado el 30 septiembre 2016. URL: http://corpusarchivos.revues.org/577 ; DOI : 10.4000/corpusarchivos.577

DORCÉ, A. (2009), Las audiencias y consumos de la televisión pública en México. Una aproximación desde la convergencia digital, (inédito).

DRI, R. (1997), Proceso a la Iglesia argentina, Biblos, Buenos Aires.

DUBOIS, Ph. (2001), "Máquinas de imagen: una cuestión de línea general”, en Video, Cine, Godard, Buenos Aires: Libros del Rojas (Universidad de Buenos Aires).

DUCROT, O. (2001), El decir y lo dicho, Edicial, Buenos Aires.

DUCROT, O. y SCHAEFFER, J. M. (1998), Nuevo diccionario enciclopédico de las ciencias del lenguaje, Arrecife Producciones, Madrid.

DURKHEIM, E. (1995), Las formas elementales de la vida religiosa, Diálogo Abierto, México.

--(2002), Las reglas del método sociológico, Fondo de Cultura Económica, Buenos Aires.

EAGLETON, T. (1996), La función de la crítica, Paidós, Barcelona.

ECO, U. (1993), Signo, Labor, Barcelona.

------(2000 [1976]) Tratado de semiótica general, Lumen, Barcelona.

---------(1987), La estrategia de la ilusión, Lumen- De la Flor, Buenos Aires.

--------(1984), Obra abierta, Planeta-De Agostini, Barcelona.

-----(1997 [1968]), Apocalípticos e integrados, Lumen- Tusquets, Barcelona.

---------(1996), Seis paseos por los bosques narrativos, Lumen, Barcelona.

---------(1993), Lector in fabula, Lumen, Barcelona. 
EISENSTEIN, E. (2010), La imprenta como agente de cambio. Comunicación y transformaciones culturales en la Europa moderna temprana, Fondo de Cultura Económica, México.

ENAUDEAU, C., (1998), La paradoja de la representación, Paidós, Buenos Aires.

ESQUIVEL, J. C. (2000), "Notas sobre las esferas diferenciadas de valor en Max Weber", en: Revista Ciências Sociais e Religiaa Nº1, Porto Alegre.

-(2004), Detrás de los muros: la Iglesia Católica en tiempos de Alfonsín y Menem (1983-1999), Universidad Nacional de Quilmes, Bernal.

(2008), "La presencia pública de la Iglesia Católica durante los gobierno de Carlos Menem (1989-1999)", Ameigeiras, A. y Martín, J.P. (eds.), Religión, Política y Sociedad, Prometeo, Buenos Aires.

-(2010), "Notas sobre la laicidad en Argentina", Revista Debates do NER, Porto Alegre, 2010, vol. II p. 149 - 171.

-(2013a), "Narrativas y políticas en la disputa por la educación sexual en la Argentina", en: Revista Cultura y Religión, Santiago de Chile, 2013, vol. 7 pp. 140 $-163$.

(2013b), "Cuestión de Educación (sexual). Pujas y negociaciones político-religiosas en la Argentina democrática", CLACSO, ebook: http://biblioteca.clacso.edu.ar/clacso/becas/20131122034410/JCEsquivel.pdf

ESQUIVEL, J. C. y VAGGIONE, J.M. comps. (2015), Permeabilidades activas, Biblos, Buenos Aires.

FABBRI, P. (2000), El giro semiótico, Gedisa, Barcelona.

FERRY, J.M., WOLTON, D. y otros (1998), El nuevo espacio público, Gedisa, Barcelona.

FRANCO, M. (2012), Un enemigo para la nación, Fondo de Cultura Económica, Buenos Aires.

FRIGERIO, A. (1993), "La invasión de las sectas: el debate sobre nuevos movimientos religiosos en los medios de comunicación en Argentina", en: Revista Sociedad y Religión, núm. 10-11, Buenos Aires.

-(2013) «Nuestra elusiva diversidad religiosa: Cuestionando categorías y presupuestos teóricos », Corpus [En línea], Vol 3, No 2 | 2013, Publicado el 09 
diciembre 2013, consultado el 20 diciembre 2013. URL : http://corpusarchivos.revues.org/313

FOUCAULT (2002), Las palabras y las cosas, Siglo XXI, Buenos Aires. (2010), Defender la sociedad, Fondo de Cultura Económica, Buenos Aires.

-(2009), Historia de la sexualidad 1: la voluntad del saber, Siglo XXI, Buenos Aires.

-(2002), Hermenéutica del sujeto, Altamira, La Plata.

FUKUYAMA, F. (1992), El fin de la historia y el último hombre, Planeta, Barcelona.

GARCÍA CANCLINI, N. (2009), "Los campos culturales en la era de convergencia tecnológica", en: Pensar lo contemporáneo: de la cultura situada a la convergencia tecnológica, Anthropos-UAM, México.

GENETTE, G. (1989), Palimpsestos. La literatura en segundo grado, Taurus, Madrid.

GIDDENS, A. (1994), El capitalismo y la moderna teoría social, Labor, Barcelona.

GIMÉNEZ BELIVEAU, V. (2008), "Pluralización del campo religioso y crisis institucional en Buenos Aires y periferia: una mirada desde las comunidades católicas", en: Ameigeiras, A., y Martín, J.P. (eds.), Religión, política y sociedad. Pujas y transformaciones en la historia argentina reciente, Prometeo Libros.

GIMÉNEZ BELIVEAU, V., y MONTENEGRO, S., (2013), "Religión y medios de comunicación a través del caso de la "Triple Frontera"', en: Giménez Beliveau, V., y Giumbelli, E. (coords.), Religión, cultura y política en las sociedades del siglo XXI, Biblos.

GOODY, J. y WATT, I. (1996 [1968]), "Las consecuencias de la cultura escrita", Cultura escrita en sociedades tradicionales, Gedisa, Barcelona.

GOODY, J. (1996 [1968]), comp., Cultura escrita en sociedades tradicionales, Gedisa, Barcelona.

GOODMAN, N. (1990), Maneras de hacer mundos, Visor, Madrid. --(1995), De la mente y otras materias, Visor, Madrid.

GOFFMAN, E. (2006), Estigma: la identidad deteriorada, Buenos Aires, Amorrortu. 
GOMIS, L. (1991), Teoría del periodismo. Cómo se forma el presente, Paidós Ibérica, Barcelona.

GONZALEZ, H. (1992), La realidad satírica. 12 hipótesis sobre Página/12, Paradiso, Buenos Aires.

GREIMAS, A. y COURTÉS, J. (1991), Semiótica. Diccionario razonado de la teoría del lenguaje, Tomo II, Gredos, Madrid.

HABERMAS, J. (1981), Historia y crítica de la opinión pública, Gustavo Gili, Barcelona.

HALL, S. (1996), "Codificar/decodificar", en: Culture, Media, Language. Working Papers in Cultural Studies, Londres, Routledge \& The CCCS University of Birmingham.

HAMON, P. (1991), Introducción al análisis de lo descriptivo, Edicial, Buenos Aires.

HARRIS, S. (2005), El fin de la fe, Paradigma, Sevilla.

HASELOFF, O. (1971) comp., La comunicación, Tiempo Nuevo, Caracas.

HAVELOCK, E. A. (2008, [1992]), La musa aprende a escribir, Paidós, Barcelona.

HERVIEU-LÉGER, D. (2001) La religion en miettes ou la question des sectes, CalmanLévy, Paris.

--------(2004) El peregrino y el convertido, México, Del helénico.

-------(2005) La religión, hilo de la memoria, Barcelona, Herder.

-------(1996) “Catolicismo, el desafío de la memoria”, en Sociedad y Religión №14/15, Bs. As.

HJARVARD, S. (2016), “Mediatización: la lógica mediática de las dinámicas cambiantes de la interacción social” en: La Trama de la comunicación, 20(1), 235-252.

-(2006), "The Mediatization of Religion. A Theory of the Media as an Agent of Religious Change", 5th International Conference on Media, Religion and Culture: Mediating Religion in the Context of Multicultural Tension, Stockholm/Sigtuna/Uppsala, Sweden, 6-9 July, 2006.

HOUTART, F. (1998), Sociología de la religión, México, PYV.

HUNTINGTON, S. (2001), El choque de las civilizaciones y la reconfiguración del orden mundial, Paidós, Buenos Aires. 
HUYSSEN, A. (2002), Después de la gran división, Adriana Hidalgo, Buenos Aires.

IGARZA, R. (2008), Nuevos medios, La Crujía, Buenos Aires.

IVINS, W. M. (1975), Imagen impresa y conocimiento. Análisis de la imagen prefotográfica, Gustavo Gilli, Barcelona.

JAMESON, F. (1991), Ensayos sobre el posmodernismo, Imago Mundi, Buenos Aires.

JENSEN, K. B. y ROSENGREN, K. E. (1997), "Cinco tradiciones en busca del público", en: Dayan, D., (comp.), En busca del público, Gedisa, Barcelona.

JODELET, D. (1985), en: “La representación social: fenómenos, concepto y teoría", en: Moscovici, Serge (ed.), Psicología Social I y II, Paidós, Barcelona.

KERBRAT-ORECHIONI, C. (1997), La enunciación. De la subjetividad en el lenguaje, Edicial, Buenos Aires.

KOLDOBSKY, D. (2008), "Un efecto de las vanguardias" en: Revista Figuraciones $N^{\circ}$ 4, IUNA, Buenos Aires, (http://www.revistafiguraciones.com.ar/numeroactual/articulo.php?ida=81\&idn=4\&arch $=1)$.

LACAN, J. (1995 [1964]), El seminario 11. Los cuatro conceptos fundamentales del psicoanálisis, Paidós, Buenos Aires.

LAIÑO, F. (1986), Secretos del periodismo. Un gran diario visto por dentro, Plus Ultra, Buenos Aires.

LAKOFF, G. Y JOHNSON, M. (1995), Metáforas de la vida cotidiana, Cátedra, Madrid.

LANDI, O. (1992), Devórame otra vez, Planeta, Buenos Aires.

LEAVIS, D., (1999), La pantalla ubicua. Comunicación en la sociedad digital, CICCUSLa Crujía, Buenos Aires.

LOTMAN, I. M. (1996), La semiosfera, Madrid, Frónesis - Ediciones Cátedra.

LUHMANN, N. (2000), La realidad de los medios de masas, Anthropos, Barcelona. (1994), "How can the mind participate in communication?", In: Hans Ulrich Gumbrecht et all. (Ed.), Materialities of Communication, Stanford University Press, California. 
LUNA, F. (1986), Perón y su tiempo, tomos I, II y III, Sudamericana, Buenos Aires.

LYOTARD, F. (1993), La condición postmoderna, Planeta-De Agostini, Buenos Aires.

MAINGUENAU, D. (1999), Introducción a los métodos de análisis del discurso, Buenos Aires, Hachette.

(2004), ¿“Situación de enunciación" o "situación de comunicación"?

Revista electrónica Discurso.org - Año 3 Número 5.

MALLIMACI, F. (1988), Catolicismo integral 1930-1945, Biblos, Buenos Aires.

-(2015), El mito de la argentina laica, Capital Intelectual, Buenos Aires.

-(1993), "Religión, modernidad y catolicismo integral en la Argentina", en: Perfiles Latinoamericanos, № 2, pp. 105-131, Distrito Federal de México.

----(1996), "Diversidad católica en una sociedad globalizada y excluyente. Una mirada al fin del milenio desde Argentina", en: Sociedad y Religión, № 14/15, Buenos Aires.

(1999), "De la homogeneidad a la diversidad: las actuales transformaciones del campo religioso en la sociedad argentina" en Revista SOCIEDADE E ESTADO NOVOS MOVIMIENTOS RELIGIOSOS- Volumen XIV - Nro. 1 - Brasilia, Brasil, Enero / Junio; pp. 127/144.

-(2001), "Prólogo", en: Esquivel, García, Hadida y Houdin; Creencias y religiones en el Gran Buenos Aires- El caso de Quilmes, Quilmes, Universidad Nacional de Quilmes.

MALLIMACI, F. y ESQUIVEL, J.C. (2014), "La contribución de la política y el Estado en la construcción del poder religioso", Revista Argentina de Ciencia Política, Nro. 17.

MALLIMACI, F. y DI STÉFANO, R. (comp.), (2001), Religión e Imaginario Social. Manantial, Buenos Aires.

MALLIMACI, F. GIMÉNEZ BÉLIVEAU, V. (2007), "Creencias e increencias en el Cono Sur de América. Entre la religiosidad difusa, la pluralización del campo religioso y las relaciones con lo público y lo privado", Revista Argentina de Sociología, vol. 5, núm. 9, Buenos Aires, pp. 44-63.

MALLIMACI, F. y VILLA, M. (2007), Las comunidades eclesiales de base y el mundo de los pobres en la Argentina, Buenos Aires, CEIL-PIETTE. 
MALLIMACI, F. (comp.), (2008), Modernidad, religión y memoria, Colihue, Buenos Aires.

(dir.), (2013), Atlas de las creencias religiosas en la Argentina, Biblos, Buenos Aires.

MALLIMACI, F. (1996), "Diversidad católica en una sociedad globalizada y excluyente. Una mirada al fin del milenio desde Argentina", en: Sociedad y Religión, № 14/15, Buenos Aires.

MANRIQUE CASTRO, M. (1982), De apóstoles a agentes de cambio. El trabajo social en la historia de América Latina, CELATS, Lima.

MARIN, L. (2015 [1977]), Destruir la pintura, Fiordo, Buenos Aires.

MARTÍN BARBERO, J., (2002), "La educación desde la comunicación", Norma, Buenos Aires, versión electrónica: www.eduteka.org (1991), De los medios a las mediaciones, Gustavo Gili, Barcelona.

MARTIN, J. P. (1995), Movimiento de sacerdotes para el Tercer Mundo, Gudalupe, Buenos Aires.

MARTIN VIVALDI, G. (1973), Géneros periodísticos, Paraninfo, Madrid.

MASOTTA, O. (1967), El "pop-art”, Editorial Columba, Buenos Aires.

MATURANA, H. y VARELA, F. (1996), El árbol del conocimiento, Debate, Madrid.

METZ, C. (1979), Psicoanálisis y cine. El significante imaginario, Barcelona, Gustavo Gili. (1991) "La enunciación antropoide" y "Cuatro pasos en las nubes", en La enunciación impersonal. O la visión del filme, trad. cast. M. R. del Coto, (L'énonciation impersonnelle, ou le site du film, Meridiens Klincksieck, París.).

MEUNIER, J-P, (1999), "Dispositif et theories de la communicaction", Hermés 25, Paris.

MEYER, M. (1987), Lógica, lenguaje y argumentación, Hachette, Buenos Aires.

MIGNONE, E. (1986), Iglesia y dictadura, Ediciones del Pensamiento Nacional, Buenos Aires. 
MONTENEGRO, S. y GIMENEZ BELIVEAU, V. (2006), La Triple Frontera. Globalización y construcción social del espacio, Buenos Aires, Miño y Dávila.

MOSCOVICI, S. (ed.), (1985), Psicología Social I y II, Paidós, Barcelona.

MOSCHOFSKY, G. (2011), Pecado original. Clarín, los Kirchner y la lucha por el poder, Planeta, Buenos Aires.

MURARO, H. (2000), Políticos, periodistas y ciudadanos, Fondo de Cultura Económica, Buenos Aires.

NORA, D. (1997), La conquista del ciberespacio, Andrés Bello, Santiago de Chile.

NIETZSCHE, F. (1951 [1873]), "Introducción teorética sobre la verdad y la mentira en su sentido extramoral”, en Obras completas, Buenos Aires, Aguilar, Tomo I.

OBREGÓN, M. (2005), Entre la cruz y la espada. La Iglesia católica durante los primeros años del "Proceso", Universidad Nacional de Quilmes, Bernal.

ORO, A (1996), "Considerações sobre a modernidade religiosa", en Sociedad y Religión, Na 14/15, Bs. As.

OROZCO, G. (2001), Televisión, audiencias y educación, Norma, Buenos Aires.

PARKER, C. (1999), "Globalización, diversidad religiosa y democracia multicultural", ponencia presentada IX JORNADAS SOBRE ALTERNATIVAS RELIGIOSAS NA AMERICA LATINA, 21- 24 Septiembre de 1999, Centro de Filosofía y Ciencias Humanas, Universidad Federal de Río de Janeiro- Brasil.

PASTOREAU, M. (2009), Diccionario de los colores, Paidós Ibérica, Barcelona. Vista preliminar disponible en google books: http://books.google.com.ar/books?id=BrCE2I3kwRsC\&printsec=frontcover\&hl=es\&sour ce=gbs ge summary $r \& c a d=0 \# v=o n e p a g e \& q \& f=f a l s e$.

PEIRCE, Ch. S., (1955 [1905]), "The Principles of Phenomenology"- "The Categories: Firstness, Secondness, Thirdness”, en Philosophical Writings, Justus Buchler (Ed.), New York, Dover Publications, p. 74 a 93.

- (1987), Obra lógico- semiótica, Taurus, Madrid.

PISCITELLI, A. (2005), Internet, la imprenta del siglo XXI, Gedisa, Barcelona.

PRICE, V. (1994), La opinión pública. Esfera pública y comunicación, Paidós, 
Barcelona.

PRIGOGINE, I. y STENGERS, I. (1983), La nueva alianza, Alianza, Madrid.

RÉCANATI, F. (1981), La transparencia y la enunciación. Introducción a la pragmática, Hachette, Buenos Aires.

RAMONET, I., (2011), La explosión del periodismo: Internet pone en jaque a los medios tradicionales, Capital Intelectual, Buenos Aires.

RAMOS, J. (1993), Los cerrojos a la prensa, Editorial Amfin, Buenos Aires.

RODRIGO ALSINA, M. (1993), La construcción de la noticia, Paidós Ibérica.

ROMERO, G. (2015), "Sexualidad e Iglesia Católica: la educación sexual en escuelas confesionales como arena de conflicto", en: Esquivel, Juan Cruz y Vaggione, Juan Marco (dirección). Permeabilidades Activas. Religión, Política y Sexualidad en la Argentina democrática. Buenos Aires, Editorial Biblos, 2015

ROSANVALLON, P. (1995), La nueva cuestión social. Repensar el estado providencia, Bs As, Manantial.

ROSENBERG, H. (1969), La tradición de lo nuevo, Monte Avila, Caracas.

ROSZAK, Th. (1988), El culto a la información, Crítica, Barcelona.

ROY, O. (2010), La santa ignorancia. El tiempo de la religión sin cultura, Península, Barcelona.

RUESCH, J. y BATESON, G. (1965), Comunicación. La matriz social de la psiquiatría, Paidós, Buenos Aires.

SAINTOUT, F. y FERRANTE, N. (2006), ¿Y la recepción? Balance crítico de los estudios sobre el público, La Crujía, Buenos Aires.

SAÍTTA, S. (1998), Regueros de tinta. El diario Crítica en la década de 1920, Sudamericana, Buenos Aires.

SARLO, B. (1985), El imperio de los sentimientos, Catálogos, Buenos Aires.

SIDICARO, R. (1993), La política mirada desde arriba. Las ideas del diario La Nación 1909-1989, Sudamericana, Buenos Aires.

SCHOPENAHUER, A. (2004 [1819]), El mundo como voluntad y como representación, 
RBA, Barcelona.

SCOLARI, C. (2008), Hipermediaciones, Gedisa, Barcelona. (2004), Hacer click, Gedisa, Barcelona.

SEBEOK, Th. A., y UMIKER-SEBEOK, J. (1987), Sherlock Holmes y Charles S. Peirce. El método de la investigación, traducción de Lourdes Güell, Paidós, Barcelona.

SEGATO, R. (2003), Las estructuras elementales de la violencia, Universidad Nacional de Quilmes, Bernal.

SEGRE, C. (1985), "Tema/motivo", Principios de análisis del texto literario, Crítica, Barcelona.

SEMAN, P. (2004), La religiosidad popular, Capital Intelectual, Buenos Aires.

SENNET, R. (1978), El declive del hombre público, Península, Barcelona.

SETTON, D. (2008), "Instituciones e identidades en los judaísmos contemporáneos. Estudio sociológico de Jabad Lubavitch", Informes de Investigación 21, CEILCONICET, Buenos Aires.

SHINER, L. (2004), La invención del arte, Paidós Ibérica, Barcelona.

SIDICARO, R. (1993), La política mirada desde arriba. Las ideas del diario La Nación 1909-1989, Sudamericana, Buenos Aires.

SILLETA, A. (1986), Las sectas invaden la Argentina, Contrapunto, Buenos Aires.

SINI, C. (1985), Semiótica y filosofía. Signo en Peirce, Nietzsche, Heidegger, Foucault, Ricoeur y Levi- Strauss, Hachette, Buenos Aires.

SIVAK, M. (2015), Clarín. La era Magnetto, Planeta, Buenos Aires.

SMITH, A. (1983), Goodbye Gutenberg, G. Gili, Barcelona.

SORLIN, P (2004), El 'siglo'de la imagen analógica, La Marca Editora, Buenos Aires.

SONEIRA, A. J. (1989), Las estrategias institucionales de la Iglesia Católica (18801976), CEAL, Buenos Aires.

(2005), Sociología de los Nuevos Movimientos Religiosos en

Argentina, Ediciones Universidad del Salvador, Buenos Aires. 
SOPRANO, G. (2002) "A favor de una etnografía sobre clientelismo político y peronismo". Desarrollo Económico, Revista de Ciencias Sociales, pp.483-488.

(2005) "La producción de actores e identidades políticas en el peronismo durante una campaña electoral". En S. Frederic y G. Soprano (comp.) Cultura y política en etnografías sobre la Argentina. Bernal: Universidad de Quilmes, pp. 161-196.

STEIMBERG, O y TRAVERSA, O (1997), Estilo de época y comunicación mediática, Atuel, Buenos Aires.

STEIMBERG, O (1993), Semiótica de los medios masivos, Atuel, Buenos Aires.

-(2013), Semióticas. Las semióticas de los géneros, de los estilos, de la transposición, Eterna Cadencia, Buenos Aires.

STEIMBERG, O., TRAVERSA, O., SOTO, M. (eds.), 2009, El volver de las imágenes, La Crujía, Buenos Aires.

SZNAIDER, B. (2012), "Pliegues de la Argentina en sus avisos institucionales", en: Revista La Trama de la Comunicación, vol. 16, 2012. Disponible en: http://www.latrama.fcpolit.unr.edu.ar/index.php/trama/article/view/31.

TÁLICE, R. (1977), 100.000 ejemplares por hora. Memorias de un redactor de "Crítica" el diario de Botana, Corregidor, Buenos Aires.

TASSARA, M. (2001), El castillo de Borgonio, Atuel, Buenos Aires.

THOM, R. (1997), Estabilidad estructural y morfogénesis, Gedisa, Barcelona.

TOMASELLO, M. (2013), Los orígenes de la comunicación humana, Katz, Buenos Aires.

TRAVERSA, O. (2001), “Aproximaciones a la noción de dispositivo”, en: Revista Signo y Seña, núm. 12, abril.

(1997), Cuerpos de papel. Figuraciones del cuerpo en la prensa 1918-1940, Gedisa, Barcelona.

TURKLE, S. (1997), La vida en la pantalla, Paidós Ibérica, Barcelona.

URQUIZA, F. (2010), Iglesia y neoliberalismo, Biblos, Buenos Aires. 
VALDETTARO, S. (2009), "Diarios: entre internet, la desconfianza y los árboles muertos", en: El fin de los medios masivos, La Crujía, Buenos Aires.

VALLE ROJAS, C. (2006), Comunicación Participativa, Estado-nación y democracia: Discurso, Tecnología y Poder, Ediciones Universidad de La Frontera, Temuco.

VAN DIJK, T. (1990), La noticia como discurso, Paidós, Barcelona.

VARELA, F. (2005), Conocer, Gedisa, Barcelona.

VASILACHIS DE GIALDINO, I (1997), La construcción de representaciones sociales: discurso político y prensa escrita, Gedisa, Barcelona.

(2007), "Condiciones de trabajo y representaciones sociales. El discurso político, el discurso judicial y la prensa escrita a la luz del análisis sociológicolingüístico del discurso", Discurso y Sociedad, Revista Multidisciplinaria de internet.

-(2006), Estrategias de investigación cualitativa, Gedisa, Barcelona.

VERBITSKY, H. (2007), Cristo Vence, Sudamericana, Buenos Aires.

VERÓN, E. (1993), La semiosis social, Gedisa, Barcelona.

--------- (1968), Conducta, estructura y comunicación, Jorge Alvarez, Buenos Aires.

(1987), "Prefacio a la segunda edición”, Construir el acontecimiento, Gedisa,

Buenos Aires.

(1997), Semiosis de lo ideológico y del poder. La mediatización, Oficina de publicaciones CBC, Buenos Aires.

-------- (1974), “Para una semiología de las operaciones translingüísticas”, en Lenguajes, año 1, número 2, Buenos Aires, Nueva Visión.

-------(1998), Esto no es un libro, Gedisa, Barcelona.

(1999), Efectos de agenda, Gedisa, Barcelona.

------ (2001a), Espacios mentales. Efectos de agenda 2, Gedisa, Barcelona.

-------- (2001b), El cuerpo de las imágenes, Norma, Buenos Aires.

------- (2004), Fragmentos de un tejido, Gedisa, Barcelona.

------- (2013) La semiosis social 2, Paidós, Buenos Aires. 
VIOTTI, N. (2011), "Notas sobre socialidad y jerarquización en la nueva religiosidad de los sectores medios urbanos", Papeles de Trabajo, Año 5, Nº, pp. 135-152.

VIRILIO, P. (1997), El cibermundo, la política de lo peor, Cátedra, Madrid.

VIOTTI, N. y FUNES, M. A. (2015), La política de la Nueva Era: El Arte de Vivir en Argentina, DEBATES DO NER, Porto Alegre, 2015 vol. 2 p. 17 - 36.

VOLOSHINOV, V.N. (1992[1929]), El marxismo y la filosofía del lenguaje, Alianza, Madrid.

VOMMARO, G., (2011), ““Usted vino por su propia decisión”: repensar el clientelismo en clave etnográfica", en: Revista Desacatos.

-(2009), "Diez años de ¿favores por votos? El clientelismo como concepto y como etiqueta moral", en Eduardo Rinesi, Gabriel Vommaro y Matías Muraca (comps.), ¿Si éste no es el pueblo? Hegemonía, populismo y democracia en Argentina, Universidad Nacional de General Sarmiento, Buenos Aires.

-(2007), “ 'Acá no conseguís nada si no estás en política'. Los sectores populares y la participación en espacios barriales de sociabilidad política”, en Anuario de Estudios en Antropología Social 2006, Centro de Antropología Social, Instituto de Desarrollo Económico y Social, pp. 161-178.

WAINERMAN, C. y otros (2008), La escuela y la educación sexual, Buenos Aires, Manantial.

WATZLAWICK, P., BEAVIN, J. H., JACKSON, D.D. (1971), Teoría de la comunicación humana, Editorial Tiempo Contemporáneo, Buenos Aires.

WEBER, M. (1998), Ensayos sobre sociología de la religión, Taurus, Madrid, tomo 1.

WHITE, H. (1992), El contenido de la forma, Paidós, Barcelona.

WITTGENSTEIN, L. (1999) Investigaciones filosóficas, Altaya, Barcelona. (1989) Conferencia sobre ética, Paidós, Barcelona.

WOLFF, M. (2004), La investigación en comunicación de masas, Paidós, Barcelona. WIENER, N. (1988[1958]), Cibernética y sociedad, Sudamericana, Buenos Aires. WOLTON, D. (2000a), Sobrevivir a Internet, Gedisa, Barcelona.

--------(2000b), Internet, ¿y después? Una teoría crítica de los nuevos medios de comunicación, Gedisa, Barcelona. 
----------(1992), Elogio del gran público, Gedisa, Barcelona.

WORRINGER, W., (1977), El arte egipcio, Nueva Visión, Buenos Aires.

ZANATTA, L. (1996), Del Estado liberal a la nación católica, Universidad Nacional de Quilmes, Bernal.

ZAPATA, L. (2005), La mano que acaricia la pobreza: etnografía del voluntariado católico, Antropofagia, Buenos Aires. 